\author{
UNIVERSIDADE DE BRASÍLIA \\ FACULDADE DE CIÊNCIAS DA SAÚDE \\ DEPARTAMENTO DE ENFERMAGEM \\ PROGRAMA DE PÓS-GRADUAÇÃO EM ENFERMAGEM
}

DÉBORA LUIZA DE OLIVEIRA RANGEL

ASPECTOS AMBIENTAIS, SOCIAIS E A SAÚDE EM TERRITÓRIO

KALUNGA NO ESTADO DE GOIÁS, EM 2012

BRASÍLIA

2014 


\section{UNIVERSIDADE DE BRASÍLIA FACULDADE DE CIÊNCIAS DA SAÚDE DEPARTAMENTO DE ENFERMAGEM PROGRAMA DE PÓS-GRADUAÇÃO EM ENFERMAGEM}

DÉBORA LUIZA DE OLIVEIRA RANGEL

ASPECTOS AMBIENTAIS, SOCIAIS E A SAÚDE EM TERRITÓRIO KALUNGA NO ESTADO DE GOIÁS, EM 2012

Tese apresentada como requisito parcial para a obtenção do Título de Doutor em Enfermagem pelo Programa de Pós-Graduação em Enfermagem da Universidade de Brasília.

Área de Concentração: Política, Práticas e Cuidado em Saúde e Enfermagem.

Linha de Pesquisa: Processo de Cuidar em Saúde e Enfermagem

Orientador: Prof. Dr. Pedro Sadi Monteiro

BRASÍLIA 
Ficha catalográfica elaborada pela Biblioteca Central da Universidade de Brasília. Acervo 1018955.

\footnotetext{
Rangel, Débora Luíza de Oliveira.

R196a Aspectos ambientais, sociais e a saúde em território kalunga no Estado de Goiás, em 2012 / Débora Luiza de Oliveira Rangel. - 2014. 251 f. : il. ; $30 \mathrm{~cm}$.

Tese (doutorado) - Universidade de Brasília, Faculdade de Ciências da Saúde, Departamento de Enfermagem, Programa de Pós-Graduação em Enfermagem, 2014.

Inclui bibliografia.

Orientação: Pedro Sadi Montei ro.

1. Kalunga (comunidade quilambola brasileira) - Aspectos ambientais. 2. Kalunga (comunidade quilambola brasilei ra) - Aspectos sociais. 3. Saúde pública. 4. Epidemiologia. 5. Pramoção da saúde. I. Montei ro, Pedro Sadi. II. Título.
} 


\title{
ASPECTOS AMBIENTAIS, SOCIAIS E A SAÚDE EM TERRITÓRIO KALUNGA NO ESTADO DE GOIÁS, EM 2012.
}

\author{
Tese apresentada como requisito parcial \\ para a obtenção do título de Doutor em \\ Enfermagem pelo Programa de Pós- \\ Graduação em Enfermagem da \\ Universidade de Brasília.
}

\section{Aprovada em 27 de novembro de 2014}

\author{
BANCA EXAMINADORA \\ Prof. Dr. Pedro Sadi Monteiro - Universidade de Brasília /UnB \\ Presidente
}

Prof. Dr. Maurício Gomes Pereira - Universidade de Brasília /UnB Membro

Prof $^{a}$. Dr ${ }^{a}$. Lourdes M. G. dos Santos - Universidade do Estado do Pará, Instituto Evandro Chagas Membro

Prof. Dr. Weber de Lima Bonfim - Instituto de Educação Superior de Brasília/IESB Membro

Prof $^{\mathrm{a}}$. Dr ${ }^{\mathrm{a}}$. Christiane Inocêncio Vasquez - Universidade de Brasília /UnB

Membro

Prof ${ }^{a}$. Dra ${ }^{a}$. Solange Baraldi - Universidade de Brasília /UnB

Membro 
Dedico este trabalho...

Ao Meu Deus e Senhor, fortaleza minha, que é e me possibilita ser.

À minha bisa, exemplo de Mulher, por me mostrar que nossa história de vida é nossa! Nós que a construímos, e que, por isso, temos o compromisso de ir sempre além...

Ao meu pai e à minha mãe, minhas âncoras, alicerces para as minhas escolhas. De longe se fazendo tão perto, sempre... Cada passo, cada palavra, cada conquista e descoberta têm a essência deste homem e desta mulher, que me ensinaram a ser tudo que hoje sou...

Aos meus irmãos Thiago e Isabel, por representarem tudo o que representam na minha vida, por se ocuparem carinhosa e cuidadosamente de mim, acreditando e me fazendo acreditar...

Ao Daniel, meu pequeno príncipe, por me irradiar com sua alegria de menino e me ensinar um jeito único de ver a vida...

Ao Bruno, escolha recíproca de companhia na estrada da vida, pelo imenso apoio, pela divisão das angústias e aflições, principalmente nos momentos de incertezas, muito comum para quem tenta trilhar novos caminhos.

"Agora, nosso Deus, damos-te graças, e louvamos o teu glorioso nome." 


\section{AGRADECIMENTOS}

Agradeço, em primeiro lugar, a Deus, que, com suas bênçãos derramadas, me concedeu graça, sabedoria, entendimento e perseverança para vencer mais uma etapa da minha vida. Sou grata pelo conforto encontrado durante as inúmeras inquietudes com as quais me deparei nessa caminhada. Foram vários os momentos de angústia e aflição, em que somente encontrei refúgio e vigor na certeza de que Ele é o Senhor da minha vida.

Ao meu orientador, Professor Doutor Pedro Sadi Monteiro, agradeço pelo desafio proposto de estudar um tema tão importante para a saúde pública, igualmente instigante e de grande relevância social. Agradeço pelas orientações, atenção e apoio durante todo o Curso de Doutorado, contribuindo para o meu crescimento científico e intelectual.

Ao seu Irineu e à dona Edina Rangel, meus pais, meus amigos e exemplos para toda a vida. Por me proporcionarem a certeza do suporte e do aconchego necessários na jornada pelo ir mais além. Divido com vocês os méritos da concretude deste sonho!

À dona Antonieta, por ser minha raiz e fonte de sabedoria inigualável. Quanto orgulho sinto em poder dizer que sou bisneta desta mulher que me ensinou a recriar a vida sempre, removendo pedras, plantando roseiras, fazendo doces... Recomeçando... Toda a admiração e afeto...

Aos meus irmãos Thiago e Isabel, e ao meu sobrinho amado Danico, por fazerem toda a diferença na minha vida. Sem vocês nada disto seria possível. Agradeço por cultivarem e construírem este sonho lado a lado comigo.

Ao meu amado, Bruno, pelo amor, carinho, companheirismo e dedicação, compreendendo as minhas ausências e sempre fazendo planos. Obrigada pelas palavras de conforto e, sobretudo, pela presença tão marcante nesse momento importante de minha vida.

À minha família, que suportou e me ajudou a suportar o meu necessário afastamento e, em orações, participou comigo da construção deste estudo: madrinha, padrinho, afilhada, sogra, sogro, cunhadas, cunhado, tias, tios, primos e primas. Agradeço de coração!

A todos os colegas de trabalho, pelo incentivo e pela convivência que, de alguma forma ou de todas as formas, me enriqueceram ao longo destes anos. Uma singela homenagem, em forma de agradecimento especial, à Rosilda Amorim pelos ensinamentos sobre a escola da vida.

À Priscila Lima e ao Tiago Panza, amigos tão chegados quanto irmãos, por compartilharem comigo a bênção divina da amizade, sendo 'protagonistas indiretos' de cada momento vivenciado ao longo deste curso. 
Às amigas de pensionato que, quando tudo era um embrião de sonho e ousadia, fizeramse presente e se lançaram comigo no desafio. Parece que foi ontem... Tainá, Patrícia, Dani, Maria Inês e Bela, verdadeiramente obrigada!

Às Professoras Ana Beatriz Azevedo Queiroz e Ana Maria Domingues e ao Dr. João Aprígio Guerra de Almeida, cujos exemplos tanto me inspiraram a trilhar este caminho. Talvez, nem eu soubesse precisar o quanto dessas profissionais há em mim. $\mathrm{O}$ reconhecimento e a gratidão são imensuráveis.

Ao Professor César de Oliveira, pelo exemplo de profissionalismo, pelo incentivo e pelas valiosas sugestões durante a fase de análise dos dados, tempo em que os desafios do doutoramento se somavam aos do dia a dia em outro país.

Aos Professores da Pós-Graduação em Enfermagem da Faculdade de Ciências da Saúde da Universidade de Brasília - PPGEnf, pelos ensinamentos proferidos em suas aulas os quais foram imprescindíveis para fomentar em mim o olhar aguçado e inquieto inerente ao pesquisador na produção do conhecimento científico.

À toda a equipe de funcionários PPGEnf, pelo acolhimento e por me fazer sentir parte da história desta casa.

Aos colegas do Programa de Pós-Graduação, mestrandos e doutorandos, que, como eu, cederam aos desafios da busca infindável de respostas frente às lacunas do conhecimento científico. Obrigada pelo convívio de tantas horas e pelas experiências comuns que tivemos.

Aos queridos companheiros de viagem Brasília-Sítio Histórico e Patrimônio Cultural Kalunga, por enriquecerem ainda mais estes momentos. Agradeço, em especial, ao Francisco, à Ana Beatriz e à Verônica, pela disponibilidade e presteza.

Aos alunos do Curso de Graduação em Enfermagem com os quais tive a oportunidade de compartilhar alguns momentos da etapa de campo desta pesquisa, em especial, a Jarine Manuelle, pelo companheirismo nos momentos inusitados.

A todos os remanescentes de quilombos, em especial, à Comunidade Kalunga dos municípios de Cavalcante, Teresina de Goiás e Monte Alegre, pela receptividade e pela razão deste trabalho.

Enfim, a todos aqueles, que direta ou indiretamente me apoiaram, me incentivaram e auxiliaram para a conclusão desta tese. Sinceramente e singelamente, obrigada! Esta conquista tem muito mais de vocês do que se pode imaginar!

Eternamente Grata... 
"Em todo o mundo... Minorias étnicas continuam a ser desproporcionalmente pobres, desproporcionalmente afetadas pelo desemprego e desproporcionalmente menos escolarizadas que os grupos dominantes. Estão sub-representadas nas estruturas politicas e super-representadas nas prisões. Têm menos acesso a serviços de saúde de qualidade e, conseqüentemente, menor expectativa de vida. Estas, e outras formas de injustiça racial, são as cruéis realidades do nosso tempo, mas não precisam ser inevitáveis no nosso futuro".

(Kofi Annan, março 2001) 


\section{RESUMO}

DLOR (Rangel, Débora), Aspectos ambientais, sociais e a saúde em território Kalunga no Estado de Goiás, em 2012. 2014. 251. Tese (Doutorado) - Departamento de Enfermagem, Faculdade de Ciências da Saúde, Universidade de Brasília, Brasília, 2014.

Introdução - Este estudo tem como base o conceito de saúde na interface com seus determinantes sociais. Na comunidade quilombola Kalunga é notória a existência de fragilidade quanto ao acesso a bens e serviços. As consequências históricas do processo de escravidão e sua forma de libertação influenciaram negativamente na inclusão deste grupo como partícipes no âmbito das políticas públicas, contexto, que, além de impactar nas condições de vida, contribuiu para manutenção de deletéria invisibilidade social geradora de iniquidades. Objetivos - Avaliar as condições sanitárias da população Kalunga dos municípios de Cavalcante, Teresina de Goiás e Monte Alegre, Estado de Goiás; caracterizar seu perfil socioeconômico-demográfico e epidemiológico (idade, ocupação, grau de escolaridade, estado civil, renda familiar, número de filhos); e conhecer o ambiente e as condições de saúde deste grupo em relação a doenças prevalentes, moradia, transporte, abastecimento e qualidade da água, destinação de resíduos e dejetos humanos. Metodologia Estudo do tipo transversal analítico, no qual se utilizou técnica de levantamento amostral não probabilístico por conveniência. Os dados foram coletados durante realização de oficinas de trabalho e de visitas domiciliares que visaram o preenchimento de questionário estruturado, a avaliação qualitativa dos resíduos sólidos e a coleta de materiais para as análises laboratoriais: fezes, cabelo humano, peixes e água para consumo humano. Os dados foram analisados com utilização do software IBM SPSS Statistics 21. Resultados - Foram identificadas fragilidades relacionadas às questões socioeconômica, epidemiológica e sanitária vivenciadas pelos moradores Kalungas. Em relação a infestados por parasitos intestinais, constatou-se que $16,8 \%$ dos examinados tiveram em seus exames resultados positivos para algum tipo de parasito. As variáveis estatisticamente significativas foram município de moradia $(p=0,048)$ e hábito de lavagem das mãos $(\mathrm{p} \leq 0,001)$. As variáveis: água encanada, presença de coliformes termotolerantes na água $(\mathrm{p}=0,038)$ e tratamento da água de beber $(\mathrm{p} \leq 0,001)$ associaram-se estatisticamente à variável episódio diarreico no último mês $(\mathrm{p}=0,008)$. Sobre a ação antrópica influenciando na concentração de níveis de mercúrio nos biomas do Território Kalunga, verificou-se que a concentração média de mercúrio nos peixes analisados foi $0,172 \mu \mathrm{g} / \mathrm{g}$, sendo nas espécies carnívoras $0,681 \mu \mathrm{g} / \mathrm{g}$ e nas não carnívoras $0,087 \mu \mathrm{g} / \mathrm{g}$. Constatou-se, ainda, forte associação entre as variáveis: peso, tamanho, hábitos alimentares e os níveis de mercúrio 
no tecido muscular dos peixes. Os espécimes de cachorra-facão (Rhaphiodon vulpinus) apresentaram níveis de mercúrio total acima do permitido pela legislação brasileira. $\mathrm{O}$ teor médio de mercúrio encontrado no cabelo dos quilombolas foi $0,503 \mu \mathrm{gHg} / \mathrm{g}$, valor considerado dentro dos padrões pela Organização Mundial da Saúde. Também se constatou certa insipiência na observância do princípio da equidade, haja vista a grande disparidade de oportunidades e condições de vida dos Kalungas sem relação à população em geral. Realidade que se associa à precariedade nas condições sociais e materiais, que, por vez, influenciam no processo saúde-doença, e consequentemente, na situação de saúde e qualidade de vida desse grupo étnico. Conclusão - $\mathrm{O}$ conhecimento do perfil socioeconômico-demográfico, epidemiológico e de saúde dos moradores quilombolas Kalungas pode auxiliar na implantação de medidas saneadoras por parte dos órgãos governamentais da área da saúde que atuam nos municípios citados.

Descritores: Grupos étnicos; Determinantes sociais da saúde; Nível de saúde; Condições sociais; Epidemiologia; Promoção da saúde. 


\begin{abstract}
DLOR (Rangel, Débora). Enviromental and social aspects and the health situation in the Kalunga territory, state of Goiás, 2012. 2014. 251. Thesis (Doctorate) Department of Nursing, Faculty of Health Sciences, University of Brasília, Brasília, 2014.
\end{abstract}

Introduction - This study has as its foundation the concept of health in the interface with its social determinants. The frailty of access to services in the Quilombola kalunga is notorious. The historical consequences of the process of slavery and its form of liberation influenced, in a negative matter, the participation of this group in public policies. It created a context that had a large impact in the population's life conditions, and it cooperated with the social invisibility which generated iniquities. Objectives To evaluate the sanitary conditions of the Kalunga population in the municipalities of Cavalcante, Teresina de Goiás and Monte Alegre, state of Goiás. To characterize their social, economical, demographical and epidemiological profile (age, occupation, schooling, marital status, family income, number of children). To know the population's environment and health conditions regarding prevalent illnesses, housing, transportation, water quality and supply, destination of sewage. Metodology - Study of analytical cross-sectional type in which the technique of non-probability sampling was utilized. The data were gathered during workshops and home visits which were carried out for the filling up of structured questionnaires, the qualitative evaluation of solid residues and the collecting of matters for laboratorial analysis such as feces, human hair, fish and water for human consumption. The data were analyzed through the IBM SPSS Statistics 21 software. Results - There were frailties identified and related to social, economical, epidemiological and sanitary matters experienced by the Kalunga population. In relation to individuals infested with intestinal parasites, for $16.8 \%$ of the patients the results came positive for any kind of parasite. The more meaningful statistical variables were municipality $(p \leq 0,048)$ and the washing of hands $(p \leq 0,001)$. The variables are as follows: piped water, presence of thermotolerant coliform in the water $(p \leq 0,038)$ and the treatment of drinking water $(p \leq 0,001)$ were associated statistically to the variable of diarrheic episode in the last month $\mathrm{p} \leq 0,008$ ). On the anthropic activity which influenced the concentration of mercury in the Kalunga 
territory's biome, what was seen was that the average concentration of $\mathrm{Hg}$ in the fish species which were analized was $0.172 \mu \mathrm{g} / \mathrm{g}$. In carnivorous species, the average was $0.681 \mu \mathrm{g} / \mathrm{g}$, and in non-carnivorous species $0.087 \mu \mathrm{g} / \mathrm{g}$. What was seen was a strong correlation in the association of variables such as: weight, size, eating habits and the levels of mercury in muscular tissue of the fish. The specimens of Biara (Raphiodon vulpinus) have presented total levels of mercury above the ones allowed by the Brazilian legislation. But the average level of mercury found in hair samples of the quilombola population was $0,503 \mu \mathrm{gHg} / \mathrm{g}$, one considered normal by the World Health Organization (WHO). There was also a certain incipience while observing the principle of equity, since there are almost no opportunities and life conditions for the Kalungas, in relation to the general population. A reality that is associated to the precariousness of the social and material conditions that, finally, influence the health/illness process and, consequently, also of in the situation of health and quality of life of this ethnic group. Conclusion - The knowledge of the social, economical, demographic, epidemiological and health profile of the Quilombola Kalunga population can help the health government bodies, of the municipalities that were mentioned.

Descriptors: Ethnic groups; Social determinants of health; Health status; Social conditions; Epidemiology; Health promotion. 


\section{RESUMEN}

DLOR (Rangel, Débora). Aspectos ambientales, sociales y la salud en el territorio Kalunga, estado de Goiás, en 2012. 2014. 251. Tesis (doctorado) - Departamento de Enfermería, Facultad de Ciencias de la Salud, Universidad de Brasília, Brasília, 2014.

Introducción - Este estudio tiene como base el concepto de la salud en la interfaz con sus determinantes sociales. En la comunidad Quilombola Kalunga es notoria la existencia de debilidad del acceso a bienes y servicios. Las consecuencias históricas del proceso de esclavitud y su forma de liberación representaron una forma negativa de inclusión de este grupo como participantes de las políticas públicas, un contexto que: creyó un impacto en las condiciones de vida y contribuyó para la manutención de la invisibilidad social generadora de iniquidades. Objetivos - Evaluar las condiciones sanitarias de la población Kalunga de los municipios de Cavalcante, Teresina de Goiás y Monte Alegre, en el estado de Goiás. Caracterizar su perfil socioeconómico, demográfico y epidemiológico (edad, ocupación, grado de escolaridad, estado civil, renta familiar, número de hijos). Conocer el ambiente y las condiciones de salud de este grupo en relación con prevalencia de enfermedades, habitación, transporte, abastecimiento y calidad del agua, destinación de residuos humanos. Metodología Estudio del tipo analitico transversal en lo cual se utilizó técnica de muestreo no probabilístico por conveniencia. Los datos se recogieron durante oficinas de trabajo y visitas domiciliarias que pretendieron el relleno de cuestionarios estructurados, la evaluación cualitativa de residuos sólidos y la recogida de materiales para las análisis laboratoriales: heces, pelo humano, pescado y agua para consumo humano. Los datos se analizaron con la utilización del software IBM SPSS Statistics 21. Resultados Hubieron fragilidades relacionadas a las cuestiones socioeconómicas, epidemiológicas y sanitarias que se suceden en la población Kalunga. En relación con individuos infestados por parásitos intestinales se puede ver que $16,8 \%$ de los pacientes tuvieron resultados positivos en sus exámenes para algún tipo de parásito. Las variables estadísticas más significativas fueron municipio donde viven $(\mathrm{p} \leq 0,048)$ y hábito de lavar las manos $(\mathrm{p} \leq 0,001)$. Las variables son: el agua canalizada, la presencia de coliformes termotolerantes en la agua $(\mathrm{p} \leq 0,038)$ y el tratamiento del agua potable $(\mathrm{p} \leq 0,001)$ se asociaron estadísticamente a la variable episodio diarreico en el último 
mes $(\mathrm{p} \leq 0,008)$. Sobre la acción antrópica que influye en la concentración de los niveles de mercurio en los biomas del territorio Kalunga se pudo ver que la concentración media de mercurio en las especies de pez fue $0,172 \mu \mathrm{g} / \mathrm{g}$. En especies carnívoras, la media fue $0.681 \mu \mathrm{g} / \mathrm{g}$, y en las no carnívoras $0.087 \mu \mathrm{g} / \mathrm{g}$. Hubo una correlación fuerte entre la asociación de las siguientes variables: peso, tamaño, hábitos alimenticios y los niveles de mercurio en el tejido muscular de los peces. Los especímenes de Chafalote (Raphiodon vulpinus) presentaron niveles totales de mercurio por encima de los permitidos por la legislación brasileña. Considerándolo todo, el nivel medio de mercurio encontrado en muestras de pelo de la población quilombola fue $0,503 \mu \mathrm{gHg} / \mathrm{g}$, uno considerado normal por la Organización Mundial de la Salud (OMS). También se constató una insipiencia en la observación del principio de la equidad, teniendo en cuenta la grande diferencia de oportunidades y condiciones de vida de los Kalungas, en relación con la población general. Una realidad que se asocia a la precariedad en las condiciones sociales y materiales que, por su vez, influyen en el proceso salud/enfermedad y, consecuentemente, en la situación de la salud y cualidad de vida de ese grupo étnico. Conclusión - el conocimiento del perfil socioeconómico, demográfico, epidemiológico y de la salud de la población Quilombola Kalunga puede auxiliar en la implementación de medidas sanadoras para los órganos del gobierno de la salud que actúan en los municipios citados.

Descriptores: Grupos étnicos; Determinantes sociales de la salud; Estado de salud; Condiciones sociales; Epidemiologia; Promoción de la salud. 


\section{LISTA DE FIGURAS}

Figura 1 - Determinantes sociais: modelo de Dahlgren e Whitehead.....................................6 65

Figura 2 - Determinantes sociais: modelo de Diderichsen e Hallqvist ....................................67

Figura 3 - Localização espacial do Sítio Histórico Cultural dos Kalungas .............................93

Figura 4 - Sítio Histórico Cultural dos Kalungas - Mapa Geral de Localidades .................... 94

Figura 5 - Recurso utilizado na captação da água para consumo geral ............................... 126

Figura 6 - Destinação dos dejetos humanos no domicílio ................................................. 127

Figura 7 - Principais consequências do acúmulo de lixo no espaço peridomiciliar .............. 143

Figura 8 - Consumo semanal de peixe por moradores Kalungas........................................ 148

Figura 9 - Teor de mercúrio por espécime .................................................................. 151

Figura 10 - Valor mínimo, máximo e teor médio de Hg por hábito alimentar das espécies . 153

Figura 11 - Concentração média de Hg em peixes não predadores ......................................155

Figura 12 - Concentração média de $\mathrm{Hg}$ em peixes predadores............................................ 157

Figura 13 - Correlação massa e concentração de mercúrio em peixes .................................. 158

Figura 14 - Correlação comprimento e concentração de mercúrio em peixes....................... 159

Figura 15 - Frequência das concentrações de mercúrio em cabelo humano............................161

Figura 16 - Níveis de concentração de Hg em cabelos de quilombolas Kalungas ................. 163

Figura 17 - Referências a filhos nascidos mortos por município de residência..................... 171

Figura 18 - Distribuição das referências a filhos mortos antes de completar um ano segundo

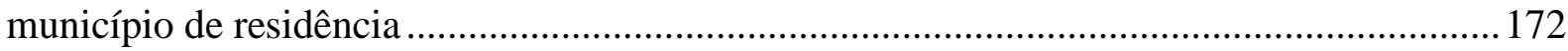

Figura 19 - Distribuição de referências ao esquema vacinal completo segundo município de

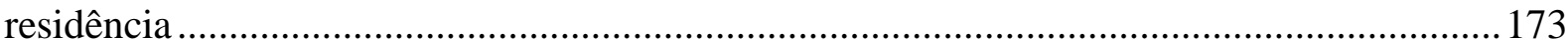

Figura 20 - Distribuição dos moradores quilombolas fumantes por município..................... 174

Figura 21 - Distribuição dos moradores quilombolas usuários de álcool, por município ..... 175

Figura 22 - Distribuição dos quilombolas hipertensos por município de residência .............. 176

Figura 23 - Distribuição dos episódios diarreicos segundo município de residência ............. 178

Figura 24 - Distribuição dos casos de escabiose segundo município de residência ............... 179

Figura 25 - Casos referidos de tracoma segundo município de residência............................ 180 


\section{LISTA DE TABELAS}

Tabela 1 - Moradores segundo município de residência no Sítio Histórico e Patrimônio Cultural Kalunga, em 2012.

Tabela 2 - Perfil epidemiológico demográfico e social dos moradores kalungas, em 2012..116

Tabela 3 - Características socioeconômicas dos quilombolas Kalungas, em 2012

Tabela 4 - Principais características dos domicílios dos quilombolas Kalungas, em 2012 ... 123

Tabela 5 - Distribuição de infestação segundo município, sexo, faixa etária e grau de escolaridade no Sítio Histórico e Patrimônio Cultural Kalunga, em 2012

Tabela 6- Distribuição de casos de diarreia no último mês, segundo, condições sanitárias dos domicílios e infestações por diferentes espécies de parasitos no Sítio Histórico e Patrimônio

Cultural Kalunga, em 2012

Tabela 7 - Características sanitárias e ambientais dos quilombolas Kalungas, em 2012 ...... 140

Tabela 8 - Frequência do consumo de pescados segundo município de moradia no Sítio

Histórico e Patrimônio Cultural Kalunga, em 2012

Tabela 9 - Caracterização dos peixes por espécie, hábito alimentar, comprimento e massa no

Sítio Histórico e Patrimônio Cultural Kalunga, em 2012.

Tabela 10 - Concentrações de Hg em diferentes espécies de peixes no Sítio Histórico e

Patrimônio Cultural Kalunga, em 2012.

Tabela 11 - Concentração de mercúrio no cabelo de quilombolas segundo município, em 2012

Tabela 12 - Aspectos socioeconômicos e concentração de mercúrio no cabelo de moradores do Sítio Histórico e Patrimônio Cultural Kalunga, em 2012. 


\section{LISTA DE SIGLAS}

\begin{tabular}{|c|c|}
\hline ABRASCO & Associação Brasileira de Saúde Coletiva \\
\hline $\mathrm{ACS}$ & Agente Comunitário de Saúde \\
\hline ADCT & Ato das Disposições Constitucionais Transitórias \\
\hline AIS & Ações Integradas de Saúde \\
\hline ANVISA & Agência Nacional de Vigilância Sanitária \\
\hline CEBES & Centro Brasileiro de Estudos de Saúde \\
\hline CNDSS & Comissão Nacional sobre Determinantes Sociais da Saúde \\
\hline CNS & Conferência Nacional de Saúde \\
\hline CONASEMS & Conselho Nacional de Secretários de Saúde \\
\hline CONASP & Conselho Consultivo de Administração de \\
\hline & Previdenciária \\
\hline DP & Desvio Padrão \\
\hline DSS & Determinantes Sociais de Saúde \\
\hline ESF & Estratégia Saúde da Família \\
\hline FUBRA & Fundação Universitária de Brasília \\
\hline FUNASA & Fundação Nacional de Saúde \\
\hline GO & Goiás \\
\hline IBGE & Instituto Brasileiro de Geografia e Estatística \\
\hline IDAGO & Instituto de Desenvolvimento Agrário de Goiás \\
\hline IDH & Índice de Desenvolvimento Humano \\
\hline INAMPS & Instituto Nacional de Assistência Médica e Previdência Social \\
\hline INPS & Instituto Nacional de Previdência Social \\
\hline IST & Valores de Ingestão Toleráveis \\
\hline MA & Maranhão \\
\hline MIF & Merthiolate-Iodo-Formol \\
\hline MRSB & Movimento pela Reforma Sanitária Brasileira \\
\hline NMP & Número Mais Provável \\
\hline OMS & Organização Mundial da Saúde \\
\hline OPAS & Organização Panamericana da Saúde \\
\hline PLpT & Programa Luz para Todos \\
\hline PNSIPN & Política Nacional de Saúde Integral da População Negra \\
\hline PPA & Plano de Pronta Atenção \\
\hline PREV-SAÚDE & Programa Nacional de Serviços Básicos de Saúde \\
\hline RPPN & Reservas Particulares de Patrimônio Natural \\
\hline RSB & Reforma Sanitária Brasileira \\
\hline SEPPIR & $\begin{array}{l}\text { Secretaria Especial de Políticas de Promoção de Igualdade } \\
\text { Racial }\end{array}$ \\
\hline SNC & Sistema Nervoso Central \\
\hline SNVA & $\begin{array}{l}\text { Sistema Nacional de Vigilância Epidemiológica e Ambiental } \\
\text { em Saúde }\end{array}$ \\
\hline SP & São Paulo \\
\hline SPSS & Statistical Package for the Social Sciences \\
\hline SUDS & Sistema Unificado e Descentralizado de Saúde \\
\hline SUS & Sistema Único de Saúde \\
\hline TCLE & Termo de Consentimento Livre e Esclarecido \\
\hline
\end{tabular}




\section{LISTA DE SÍMBOLOS}

$\begin{array}{ll}{ }^{\circ} \mathrm{C} & \text { graus Celsius } \\ \mathrm{g} & \text { gramas } \\ \mathrm{g} / \mathrm{cm}^{3} & \text { gramas por centímetro cubico } \\ \mathrm{g} / \mathrm{L} & \text { gramas por litro } \\ \mathrm{h} & \text { hora } \\ \mathrm{H}_{2} \mathrm{O}_{2} & \text { peróxido de hidrogênio } \\ \mathrm{Hg} & \text { mercúrio } \\ \mathrm{Hg}^{+2} & \text { ín mercúrico } \\ \mathrm{Hg}_{2}{ }^{+2} & \text { íon mercuroso } \\ \mathrm{HNO}_{3} & \text { ácido nítrico } \\ \mathrm{kg} & \text { quilogramas } \\ \mathrm{MeHg} & \text { metilmercúrio } \\ \mathrm{mg} & \text { miligramas } \\ \mathrm{mg} / \mathrm{kg} & \text { miligramas por quilograma } \\ \mathrm{mg} / \mathrm{L} & \text { miligramas por litro } \\ \mathrm{mL} & \text { mililitro } \\ \mathrm{mmHg} & \text { milímetro de mercúrio } \\ \mathrm{ng} . \mathrm{g}^{-1} & \text { nano gramas por grama } \\ \mathrm{ng} / \mathrm{L} & \text { nano grama por litro } \\ \mathrm{nm} & \text { nanômetro } \\ \mathrm{ppb} & \text { parte por bilhão } \\ \mathrm{ppm} & \text { parte por milhão } \\ \mathrm{SO} 4 & \text { Sulfato } \\ \mathrm{THg} & \text { mercúrio total } \\ \mu \mathrm{g} / \mathrm{g} & \text { microgramas por grama } \\ \mu \mathrm{gHg} / \mathrm{g} & \text { microgramas de mercúrio por grama }\end{array}$




\section{SUMÁRIO}

1 INTRODUÇÃ

1.1 ORIGEM E CONTEXTUALIZAÇÃO DO PROBLEMA .......................................... 30

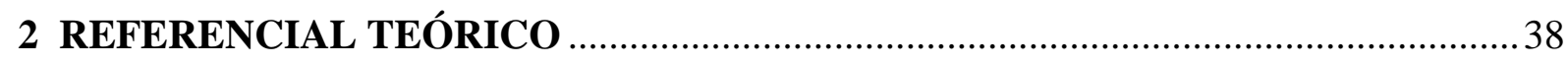

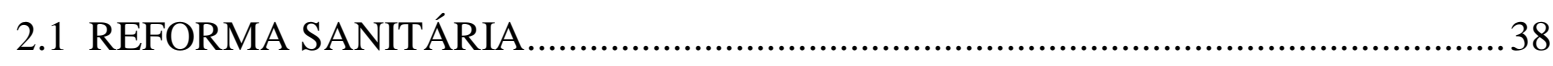

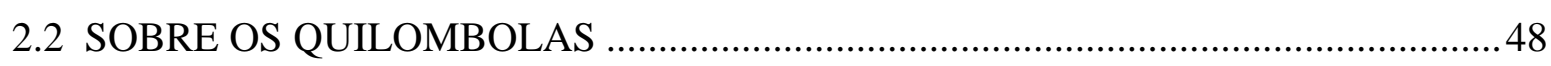

2.3 A COMUNIDADE QUILOMBOLA KALUNGA EM GOIÁS ..................................54

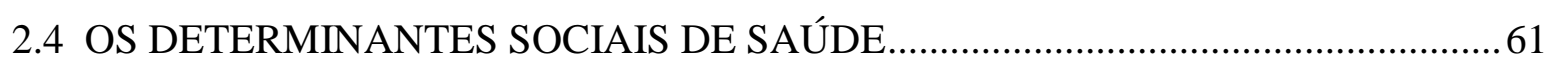

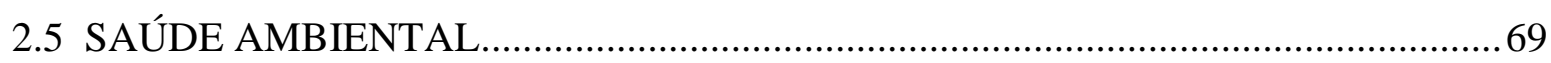

2.6 INFRAESTRUTURA, SANEAMENTO E SAÚDE.................................................... 72

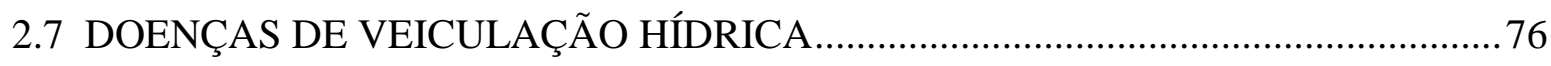

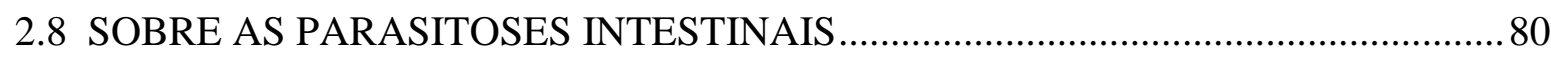

2.9 SOBRE O METAL PESADO MERCÚRIO …......................................................... 82

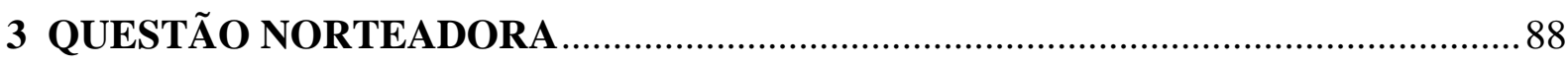

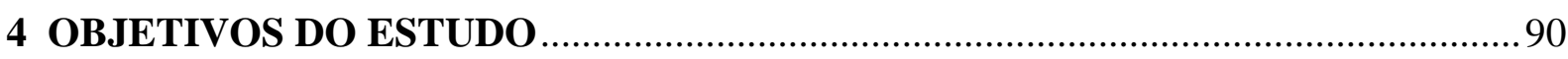

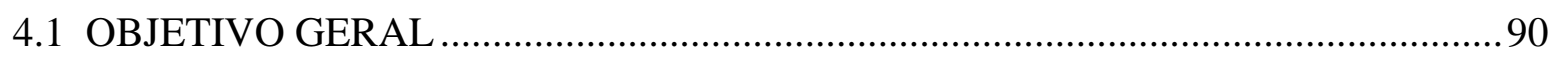

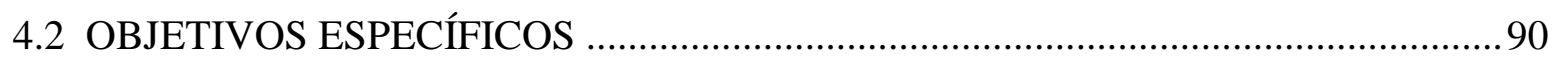

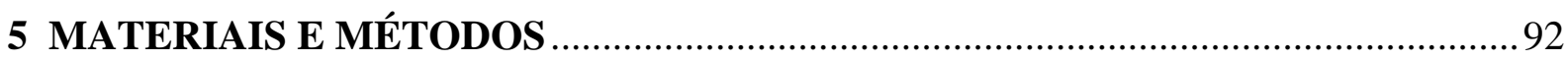

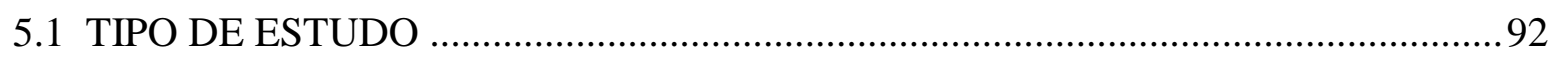

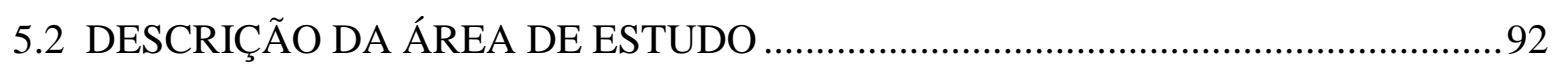

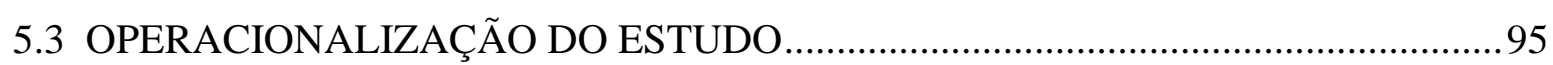

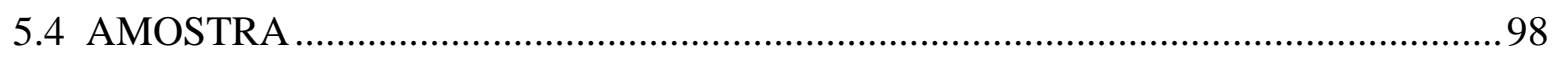

5.5 TÉCNICA DE SELEÇÃO DOS PARTICIPANTES ….............................................. 98

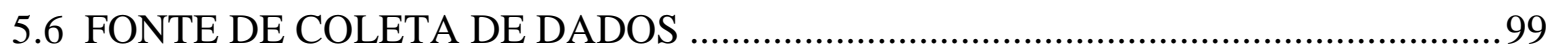

5.6.1 Visando responder o primeiro objetivo específico …..................................... 102

5.6.2 Visando responder ao segundo objetivo específico …..................................... 103

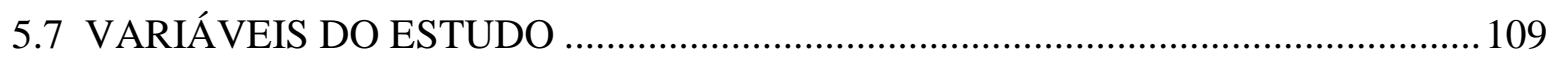

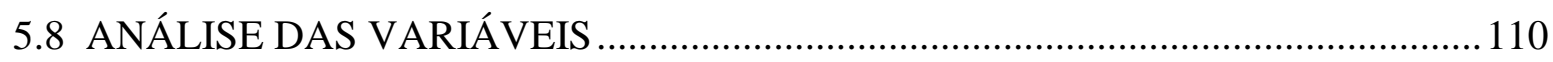

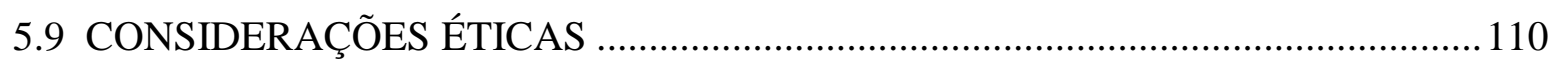

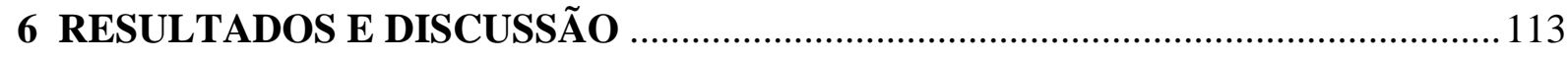

6.1 ASPECTOS SOCIOECONÔMICO-DEMOGRÁFICOS E EPIDEMIOLÓGICOS .. 114

6.2 CARACTERIZAÇÃO DO PERFIL PARASITOLÓGICO .....................................129

6.3 DESCRIÇÃO DAS CONDIÇÕES SANITÁRIAS, AMBIENTAIS E DE SAÚDE .. 139 
6.3.1 Aspectos sanitários e ambientais de moradores das comunidades quilombolas Kalungas

6.3.2 Aspectos ambientais relativos à ação antrópica: investigação sobre possível contaminação, no ambiente e em moradores quilombolas kalungas, decorrente de atividade mineradora na região

6.3.3 Caracterização das condições de saúde de moradores Kalungas .................... 166

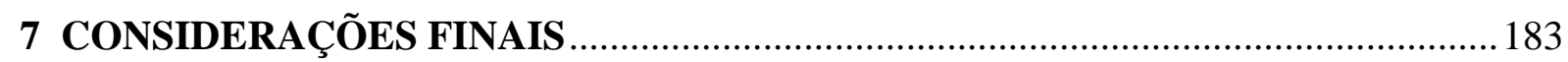

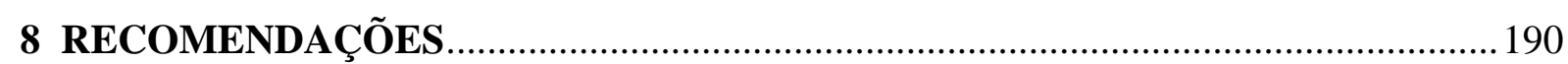

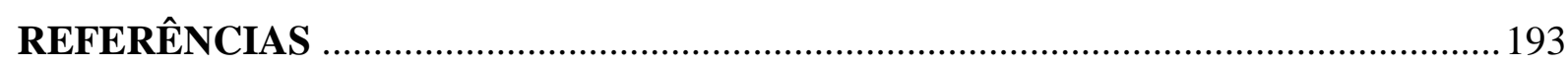

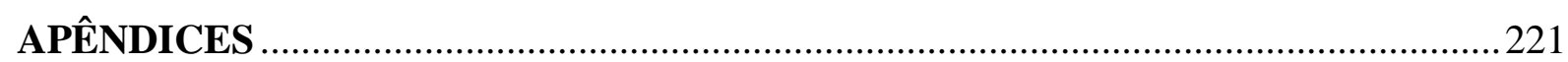

APÊNDICE A - TERMO DE CONSENTIMENTO LIVRE E ESCLARECIDO - TCLE

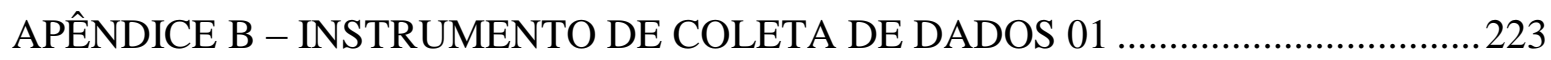

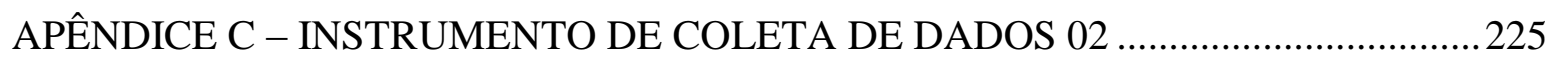

APÊNDICE D - INSTRUMENTO DE COLETA DE DADOS 03 ................................227

APÊNDICE E - INSTRUMENTO DE COLETA DE DADOS 04 ..................................233

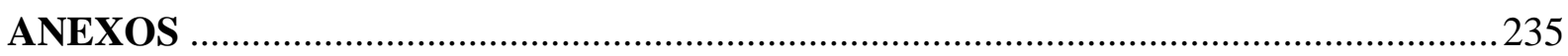

ANEXO A - Parecer favorável emitido pelo Comitê de Ética em Pesquisa com Seres Humanos da Faculdade de Ciências da Saúde da Universidade de Brasília......................235

ANEXO B - Documento de Autorização do Presidente da Associação Quilombo Kalunga

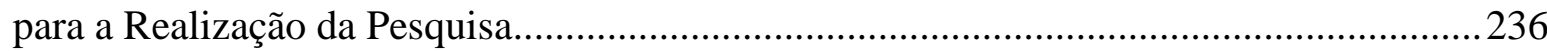

ANEXO C - Decisão do Corpo Editorial da Revista Acta Paulista de Enfermagem da UNIFESP com relação à publicação do artigo "Perfil parasitológico de uma comunidade quilombola"

ANEXO D - Cópia do Artigo "Perfil parasitológico de uma comunidade quilombola" ...238

ANEXO F - Comprovante de submissão de artigo "Mercúrio em peixes e em cabelo de populações residentes em região de garimpo" ao Corpo Editorial da Revista da Escola de Enfermagem da Universidade de São Paulo - REEUSP. 
CAPítulO 1 


\section{INTRODUÇÃO}

O presente estudo teve como ponto de partida a concepção de que a promoção da saúde está necessariamente articulada à noção de mudança nas condições de vida de indivíduos e coletividades, e não apenas à ideia de combater a doença ou dirimir os riscos de agravos. O pressuposto é respaldado pelo que preconiza a Carta de Ottawa, a qual indica que promover a saúde significa fornecer às comunidades condições para que possam ser capazes de melhorar sua saúde com vistas a uma vida com qualidade ${ }^{(1)}$.

A ideia de saúde em sua dimensão mais ampla pode ser referenciada como pilar de um estilo de vida com qualidade e bem-estar, ao passo que, também, denota a existência de vários fatores condicionantes e determinantes deste processo, tais como paz, abrigo, alimentação, renda, educação, recursos econômicos, ecossistema estável, recursos sustentáveis, equidade e justiça social ${ }^{(2)}$.

Neste sentido, faz-se de suma relevância o revisar da trajetória contextual na qual emergiu o entendimento de saúde em sua dimensão mais ampla, visto que essa reconceituação serviu de alicerce e fomento para a estruturação da promoção da saúde como campo de conhecimento e de prática, para a qualidade de $\operatorname{vida}^{(3)}$.

No panorama mundial, as primeiras décadas do século $\mathrm{XX}$ foram marcadas pela intensa medicalização da saúde e, consequentemente, por uma forma de olhar, pensar e refletir sobre este setor concentrada nas ciências biológicas e no modo de transmissão da doença. O Brasil acompanhou tal tendência, e neste período o sistema de atenção em saúde brasileiro evidenciava a duplicidade assistência/previdência, caracterizada pelo privilégio exercido pela prática médica curativa, individual, assistencialista e especializada, em detrimento da saúde pública, com priorização da capitalização da medicina e sua produção $\operatorname{privada}^{(4)}$.

O modelo de assistência à saúde, em questão, mostrou fragilidades e ainda não respondeu aos problemas da organização de ações e serviços de saúde de maneira a atender às necessidades de saúde da população. Eram evidentes as precárias condições de vida das camadas populares, os problemas de saúde decorrentes dessa condição e, principalmente, o forte caráter não inclusivo que restringia o acesso aos serviços aos trabalhadores com carteira assinada. Isto, em uma conjuntura na qual o trabalho informal caracterizava-se enquanto ocupação de grandes contingentes populacionais ${ }^{(5)}$. Por isso, paralelamente ao próprio 
desenvolvimento desse sistema de saúde, inicia-se um movimento intelectual e político de crítica ao mesmo.

Assim, o final dos anos 60 e início dos anos 70, período marcado pela grande repressão política da ditadura no Brasil, caracterizou-se pelo surgimento de ideias sobre a medicina social. Essa tinha como ponto focal a superação das deficiências do modelo de assistência à saúde até então vigente, com vistas à melhoria na qualidade de vida da população $^{(5)}$.

O complexo processo de Reforma Sanitária brasileira começou a se organizar e estabelecer suas primeiras raízes $^{(6)}$. Esse movimento de reflexões acerca da saúde da população e sobre o sistema de saúde em si apoiou-se tanto na incorporação de conceitos das ciências sociais, evidenciando que a doença é, também, socialmente determinada, quanto na importância atribuída aos questionamentos sobre o modelo médico-assistencial privatista, cuja dimensão de assistência se orientava por uma abordagem biologicista e excludente que não atendia aos anseios nem às necessidades do povo brasileiro ${ }^{(7)}$.

Ao longo dos anos, especialmente durante a década de 1980, a luta pela reforma sanitária da saúde se intensificou e ganhou novos atores políticos ${ }^{(8)}$. Antes confinado às universidades, aos partidos clandestinos, a certos grupos sociais e aos profissionais da saúde, este passou cada vez mais a ser localizado no interior do próprio Estado brasileiro. Isso ocorreu em consequência do processo chamado de "abertura" política e da incorporação ao movimento reformista de outros segmentos da sociedade, como centrais sindicais, organizações da sociedade civil e alguns parlamentares ${ }^{(9)}$.

O termo 'Reforma Sanitária' foi utilizado pela primeira vez no país sob influência da reforma sanitária italiana. Mais tarde, foi retomado nos debates prévios da VIII Conferência Nacional de Saúde para se referir ao conjunto de ideias que fundamentavam as mudanças e transformações descritas como necessárias na área da saúde ${ }^{(10)}$. Ou seja, nesse ideário de democratização sustentado pelo processo da Reforma Sanitária Brasileira, a saúde é vista a partir de uma concepção ampliada, pautada em um modelo de atenção que a reflete enquanto direito do cidadão, e dever do Estado, garantido por meio do acesso universal aos bens e serviços que a promovam e a recuperem ${ }^{(11)}$.

O principal marco histórico nesse contexto foi, sem dúvida alguma, a VIII Conferência Nacional de Saúde - CNS, convocada pelo Decreto Presidencial n. ${ }^{\circ} 91.466$ e realizada entre 
17 e 21 de março de 1986, em Brasília. Essa Conferência se caracterizou pelo consenso de que para o setor da saúde no Brasil não era suficiente apenas uma reforma administrativa e financeira, mas sim uma mudança em todo o arcabouço jurídico-institucional em vigor, para, desta forma, se contemplar, de fato, a ampliação do conceito de saúde segundo os preceitos da reforma sanitária. O relatório final produzido nessa Conferência serviu de referência para os constituintes que elaboraram a Constituição de $1988^{(4)}$.

A primeira grande contribuição da VIII CNS foi revisar o conceito de saúde:

\begin{abstract}
Em seu sentido mais abrangente, a saúde é a resultante das condições de alimentação, habitação, educação, renda, meio-ambiente, trabalho, transporte, emprego, lazer, liberdade, acesso e posse de terra e acesso a serviços de saúde. É assim, antes de tudo, o resultado das formas de organização social da produção, as quais podem gerar grandes desigualdades nos níveis de vida ${ }^{(12)}$.
\end{abstract}

A partir de 1988, a Constituição Federal dá forma aos principais pontos pactuados por ocasião da referida conferência. O artigo 196 do texto constitucional dispõe que "A saúde é direito de todos e dever do Estado, garantido mediante políticas sociais e econômicas que visem à redução do risco de doença e de outros agravos e ao acesso universal e igualitário às ações e serviços para sua promoção, proteção e recuperação" ${ }^{\text {(13) }}$. Tal feito pode ser considerado uma conquista social sem precedentes, dado que a saúde teve seu conceito ampliado, passando a ser assegurada legalmente com suas ações de promoção e manutenção reconhecidas como dever do Estado.

Desta maneira, a saúde em sua nova perspectiva conceitual, passa a ser entendida enquanto premissa de cidadania resultante das condições de alimentação, habitação, educação, renda, meio ambiente, trabalho, transporte, emprego, lazer, liberdade, acesso e posse da terra e acesso aos serviços de saúde ${ }^{(12)}$. A magnitude do proposto extrapola os limites do modelo biologicista, se opondo definitivamente a ideia de saúde como o contrário de doença e de doença como o contrário de saúde ${ }^{(14)}$. Acrescenta-se a isso a compreensão de que, para uma pessoa ou coletividade ter saúde, é necessário que essa tenha o bem-estar físico, mental, emocional, financeiro, direito à moradia, educação, lazer, entre outros aspectos que propiciem seu desenvolvimento integral e bem-estar.

A complexidade inerente a essa concepção passa a abranger outros fatores condicionantes e determinantes e a exigir nova atitude diante dos enfrentamentos no campo da saúde $^{(15)}$. Mais do que curar doenças ou minimizar potenciais riscos, a atenção em saúde deve buscar parcerias interdisciplinares e intersetoriais para aumentar sua resolutibilidade, 
apropriando-se de práticas que superem a dicotomia curativo-preventivo e possam, mais eficazmente, influenciar de forma favorável na qualidade de vida das pessoas, famílias e coletividades.

O que se evidencia é que o próprio conceito de saúde ressalta que os seus condicionantes e determinantes extrapolam o setor saúde. E, consequentemente, o planejamento ou a implementação de ações nesse campo não se sustenta fora de uma contextualização socioambiental, com vista à promoção das mudanças necessárias para o bem-estar e a melhoria da qualidade de vida. O reconhecimento da complexidade da sociedade, bem como das relações de interdependência entre os diversos setores que a compõem, emerge como pedra angular para o desenvolvimento de um contexto favorável a saúde ${ }^{(16)}$.

\footnotetext{
"A crise do financiamento do modelo de saúde centrado na doença exige o estabelecimento de novas estratégias que recuperem o paradigma da saúde centrado na qualidade de vida e desenvolvimento global das comunidades com participação dos cidadãos. (...) é possível vislumbrar metas comuns que valorizem a importância das ações intersetoriais e de promoção da saúde ao mesmo tempo que seguir buscando formas autônomas e criativas para a atenção integral à saúde"(17).
}

Destarte, a saúde pode se configurar em necessidade humana cuja satisfação associa-se imediatamente a um conjunto de condições, bens e serviços que permitem o desenvolvimento individual e coletivo de capacidades e potencialidades compatíveis com os níveis de recursos sociais existentes e com os padrões culturais de cada contexto específico ${ }^{(18)}$.

O panorama de novas interfaces estabelecidas pelo setor saúde destaca, também, a relevância de uma aproximação com as questões relativas ao meio ambiente na tecedura de proposições e na delineação de demandas no contexto de saúde como bem-estar e qualidade de vida. Portanto, a relação saúde-doença é um processo coletivo, complexo e multifatorial que indica, obrigatoriamente, a necessidade de recuperar o sentido do 'lugar' como o espaço organizado para a análise e intervenção, a partir de toda uma contextualização do sujeito e das relações entre as condições de saúde deste com seus determinantes culturais, sociais e ambientais $^{(19)}$.

Assim, a saúde do homem está diretamente relacionada à saúde do meio ambiente que o circunda, e "a existência de um é a própria condição da existência do outro" ${ }^{\text {"(20) }}$, razão pela qual se torna cada vez mais premente o refletir sobre saúde, considerando-se abordagens que abranjam o homem e sua relação com o meio ambiente. Vários são os fatores ambientais que podem afetar a saúde humana. Esses decorrem das chamadas 'situações de risco tradicionais', 
como a contaminação das águas e dos alimentos, a ausência de saneamento, a maior exposição aos vetores, às condições precárias de moradia. Ou ainda, são atribuídos a riscos 'modernos' ilustrados pelo cultivo intensivo de alimentos e monoculturas, pela poluição do ar e mudanças climáticas globais, pelo manejo inadequado de fontes energéticas, entre outros ${ }^{(21)}$.

Em face da velocidade dos avanços tecnológicos e científicos, e de uma inconsequente mudança nas relações estabelecidas entre o homem e o meio, muitas vezes há o predomínio de um movimento centrífugo, cujo saldo é o desequilíbrio na razão saúde/ambiente saudável. Por vezes, de modo infrene, a sociedade produz seu mundo de relações a partir de uma base material, um mundo que vai se desenvolvendo e se criando à medida que se aprofundam as relações econômicas e políticas da sociedade com o próprio espaço. A atividade transformadora desordenada do homem acaba acentuando desigualdades sociais e cria ambientes extremamente problemáticos, com má qualidade de vida e saúde ${ }^{(22)}$.

Mesmo que de modo superficial, algumas perspectivas acerca da problemática ambiental estiveram inseridas no campo de estudo da Saúde Pública desde seus primórdios. A priori, o tema saneamento básico (água, esgoto, lixo) foi quase que o único associado aos determinantes ambientais da saúde.

Contudo, na segunda metade do século XX, com o aprofundamento das discussões sobre saúde em seu conceito ampliado, a saúde ambiental foi sendo estruturada em áreas específicas que passaram a fazer parte dos aspectos correlatos à saúde humana. A década de 1970 destacou-se neste contexto, pois foi o período no qual, mesmo que sem um vínculo direto com o setor saúde, foram estabelecidas ações de controle da poluição, em um enfoque de ambiente além da dimensão puramente sanitarista ${ }^{(23)}$.

O cenário fomentado pelo movimento de reforma sanitária abriu caminho para a incorporação da concepção de uma 'Saúde Ambiental Moderna'(24). Esta construção superou a compreensão do ambiente enquanto algo externo ao homem e traduzido nas expressões "ambiente físico", "ecossistema" ou "espaço geográfico". A partir dela se preconiza que, mais do que a identificação de riscos ambientais e o estabelecimento da relação de causalidade desses malefícios à saúde humana, as questões relativas ao meio ambiente sejam incorporadas enquanto determinantes ou condicionantes de saúde e, assim, engajados e internalizados à política, ao diagnóstico, ao planejamento e às ações de saúde ${ }^{(25)}$. Tais considerações incluem os fatores físicos, químicos, biológicos, sociais e psicológicos nas interações com o meio 
ambiente, objetivando correlacionar teoria e prática e, assim, valorar, corrigir, controlar e evitar prejuízos à saúde de gerações atuais e futuras ${ }^{(26)}$.

Por outro lado, apesar dos grandes avanços em relação à incorporação das questões ambientais no planejamento das ações de promoção, proteção e recuperação da saúde, muito ainda se tem que caminhar para a inclusão nessas ações dos atores sociais que estão envolvidos no processo de transformação do ambiente e que, por isso, também são responsáveis pela identificação e incremento, ou não, de demandas em saúde relacionados ao meio em que vivem.

Cada grupo social é singular e apresenta características que correspondem a uma diversidade de fatores que pertencem e relacionam-se com as condições de vida e saúde local $^{(27)}$. Nesse sentido, a perspectiva é trabalhar em conjunto com a comunidade e conjugar, de fato, a identificação e análise de padrões de distribuição espacial de fatores de risco e/ou doenças com a presença e alocação dos componentes infraestruturais e de recursos humanos que afetam as condições de vida e saúde. É de suma importância incluir a díade ambiente e saúde enquanto pano de fundo para a abordagem geográfico-epidemiológica, levando-se em consideração tanto a especificidade do contexto no qual a população se insere quanto seus determinantes sociais da saúde, principalmente, no que se refere às condições de saneamento, meio ambiente e saúde.

Em decorrência disso, no âmbito das ações e serviços prestados pelo Sistema Único de Saúde - SUS, cada vez mais, se amplia a compreensão de que há um ambiente maior e relacional, em que atenção em saúde deve ser prestada levando-se em consideração o espaço onde as pessoas residem e trabalham, reforçando o conceito de ambiente enquanto fruto do intercâmbio entre sociedade e natureza.

Atualmente, o Brasil, conta com programas institucionais desenvolvidos com o objetivo de integrar as vigilâncias sanitária, epidemiológica e ambiental, na busca da Vigilância em Saúde, a partir da incorporação pelo SUS da Vigilância Ambiental ao Sistema Nacional de Vigilância Epidemiológica e Ambiental em Saúde - SNVA. A Vigilância Ambiental em Saúde é definida pela Fundação Nacional da Saúde como um conjunto de ações que proporciona o conhecimento e a detecção de qualquer mudança nos fatores determinantes e condicionantes do meio ambiente que interferem na saúde humana, com a 
finalidade de identificar as medidas de prevenção e controle dos fatores de risco ambientais relacionados às doenças ou outros agravos à saúde ${ }^{(28)}$.

Nesta perspectiva, a Vigilância da Qualidade da Água para Consumo Humano, parte integrante da Vigilância Ambiental em Saúde, pode ser apontada como importante elo entre o setor saúde e os setores de saneamento e meio ambiente. Tal integração ocorre a partir das ações e, principalmente, das informações de vigilância - ambiental e epidemiológica -, com as ações e informações relativas à prestação dos serviços em saúde, nos aspectos da cobertura e da qualidade do atendimento ${ }^{(29)}$.

Assim, os indicadores epidemiológicos podem ser considerados fundamentais para a representação dos efeitos das ações de saneamento, ou, ainda, das consequências de sua insuficiênciana saúde das populações. Tais indicadores podem ser comparados às impressões digitais de uma dada comunidade, revelando suas principais características e demandas. E, por isso, são utilizados enquanto ferramentas indispensáveis tanto para a vigilância ambiental em saúde quanto para a orientação de programas e planos de alocação de recursos em saneamento ambiental, com vistas à promoção da saúde e de um estilo de vida com mais qualidade.

Frente ao exposto, pode-se destacar que nestes mais de 20 anos de consolidação do SUS, a saúde ambiental pode ser compreendida como uma área que, apesar de recente, demostra destaque enquanto componente integrante de uma Saúde Pública renovada. A saúde ambiental não só integra o movimento de promoção da saúde, mas também busca fortalecer o debate sobre os determinantes socioambientais e seus impactos na saúde ${ }^{(30)}$.

Esta é uma tarefa árdua ainda mais quando enfocamos a vulnerabilidade de grupos minoritários que, muitas vezes, encontram-se em situações limitantes quanto ao acesso a serviços e políticas públicas. Em nosso país, ainda vivemos uma realidade em que o saneamento ambiental inadequado reflete um quadro de exclusão social combinado com novos problemas de saúde. Desta maneira, é fundamental compreender como as populações socialmente vulneráveis atribuem significados às suas condições de vida e atuam no meio em que se inserem. Isso reflete o modo como percebem sua saúde e conhecem e/ou reconhecem os riscos, agravos e necessidades, modificando-os ou adaptando-se a estas condições ${ }^{(31)}$. A realização de estudos acerca das condições sanitárias e epidemiológicas pode retratar a especificidade desses grupos sociais, o que contribui para o incremento do Sistema Ambiental em Saúde. Tais trabalhos fornecem um substrato valioso para a produção, integração, 
processamento e interpretação de informações que, por sua vez, servem de instrumentos para que o Sistema Unificado de Saúde possa planejar e executar ações relativas à promoção de saúde e de prevenção e controle de doenças relacionadas ao ambiente ${ }^{(28)}$.

A temática saneamento no Brasil é um problema de saúde pública de grande destaque para a população pela sua relevância para a saúde do homem e do meio ambiente ${ }^{(29)}$. De maneira geral, há um déficit de acesso domiciliar aos serviços de saneamento básico no país. E este déficit distribui-se de forma desigual ${ }^{(30)}$. A desigualdade na distribuição da infraestrutura em saneamento no país faz com que esta se concentre nas regiões urbanas e nas cidades com maior desenvolvimento econômico ${ }^{(31)}$.

Assim, a situação evidenciada no ambiente rural brasileiro é de precariedade, caracterizada pela ausência ou menor acesso dessas populações às medidas de saneamento básico $^{(32)}$. Em decorrência da singularidade do cenário em referência, onde não existem aglomerados 'normais', se evidência uma realidade desprovida de condições básicas de vida, o que pode acarretar risco à saúde.

Os Kalungas formam uma comunidade rural de origem quilombola que pode ser citada como uma parcela da população, onde é notória a exposição dos moradores a agravos em saúde oriundos da precariedade local nas condições de vida. As consequências históricas do processo de escravidão e a forma de sua libertação influenciaram e ainda influenciam no acesso diferenciado a bens e serviços. Os Kalungas enfrentam problemas relacionados às condições de moradia, baixo nível educacional, precariedade, ou até mesmo, total ausência de serviços de saneamento básico e distribuição de água potável $^{(36)}$.

Frente à vulnerabilidade dessa comunidade, a busca pela efetivação do direito à saúde enquanto dever do Estado torna necessário mais do que a priorização do acesso a serviços médicos-assistenciais. É fundamental um olhar atentivo para a interface saúde e seus determinantes sociais, em especial, os correlatos à infraestrutura sanitária e ao meio ambiente; posto que o conjunto das condições naturais, sociais e culturais em que vive a pessoa humana são suscetíveis de influenciar sua existência, e principalmente sua saúde ${ }^{(37)}$.

Assim sendo, o desenvolvimento desse estudo, que tem como objetivo avaliar as condições sanitárias da população Kalunga pode contribuir, sobremaneira, na geração de informações e proposições resolutivas tanto que auxiliem na identificação e, por desdobramento, no atendimento das necessidades de saúde dessas comunidades, quanto que 
contribuam com a minimização do quadro de exclusão social por eles vivenciados, em especial, em se tratando da garantia do direito à saúde de modo equânime.

\subsection{ORIGEM E CONTEXTUALIZAÇÃO DO PROBLEMA}

$\mathrm{Na}$ área da saúde, a aproximação com o conceito de qualidade de vida é relativamente recente e decorre, em parte, dos novos paradigmas que têm influenciado as políticas e as práticas do setor nas últimas décadas. Nesta perspectiva, a ideia de Qualidade de Vida tanto remete a um estilo de vida saudável em prol do bem-estar, quanto denota a existência de vários fatores condicionantes e determinantes nesse processo, tais como paz, abrigo, alimentação, renda, educação, recursos econômicos, ecossistema estável, recursos sustentáveis, justiça e equidade ${ }^{(2)}$.

Isto acontece porque saúde e doença não se caracterizam enquanto polos situacionais antagônicos e regidos por relações unicausais. Pelo contrário, o processo saúde-doença é complexo, multifatorial e de forte cunho social, caracterizado pelas relações dos homens com a natureza (meio ambiente, espaço, território) e com outros homens (por meio do trabalho e das relações sociais, culturais e políticas) num determinado espaço geográfico e num determinado tempo histórico ${ }^{(38)}$. Ou seja, saúde e doença configuram processos compreendidos como um continuum e relacionados aos aspectos econômicos, socioculturais, à experiência pessoal e estilos de vida ${ }^{(39)}$.

Desta maneira, a saúde, situada dentro de um contexto amplo, é influenciada por determinantes sociais, sendo inegáveis seus pontos de interface com a condição de vida dos indivíduos e grupos populacionais ${ }^{(40)}$. Em outras palavras, fatores sociais, econômicos, culturais, étnicos/raciais, psicológicos e comportamentais são capazes de influenciar na ocorrência de problemas de saúde e na delimitação do risco de agravos no contexto de cada população $^{(41)}$.

Consoante essa mudança de paradigma da saúde, a melhoria da qualidade de vida passou a ser considerada um dos resultados esperados, tanto das práticas assistenciais quanto das políticas para o setor nos campos da promoção da saúde e da prevenção de doenças de indivíduos e coletividades ${ }^{(39)}$.

Paralelamente à nova abordagem da saúde oriunda de seu conceito mais amplo, o movimento de Reforma Sanitária Brasileira - RSB também contribuiu com o reconstruir de 
uma estrutura normativa que visa atender as reais necessidades da população nas questões da saúde enquanto direito fundamental de cidadania $^{(42)}$. A conjuntura descrita forneceu um arcabouço jurídico à saúde, sendo esta preconizada como direito dos cidadãos e dever do Estado. Assim, a saúde tanto superou o reducionismo do enfoque pautado na doença quanto incorporou o respaldo advindo de proteção legal que a descreve enquanto direito fundamental de todos os brasileiros.

A saúde enquanto direito se constitui em um avanço social sem precedente e significa a garantia pelo Estado, de condições dignas de vida e de acesso universal e igualitário às ações e serviços de promoção, proteção e recuperação da saúde em todos os seus níveis, a todos os habitantes do território nacional, com vista ao desenvolvimento pleno do ser humano em sua individualidade ${ }^{(12)}$. Direito este, por sua natureza, interligado a vários outros.

Frente à abrangência conceitual descrita, é possível afirmar que a promoção da saúde não constitui atribuição restrita a este setor, mas uma integração entre os diversos setores do governo, os quais devem priorizar a articulação de políticas e ações que culminem, de fato, com a melhoria das condições de vida da população e da oferta de serviços essenciais aos seres humanos ${ }^{(42)}$. Ou seja, para se ter saúde, a responsabilidade vai além desse setor, sendo fundamental que as políticas públicas correlatas à área tenham propostas complementares e harmônicas; pois, caso essas não estejam em conjunto com as políticas públicas e com as ações em saúde, tal direito fundamental, jamais será um objetivo conquistado em nosso país $^{(40)}$.

Contudo, apesar das conquistas sociais alcançadas nas últimas décadas, grandes parcelas da população brasileira ainda sofrem de problemas geradores de importantes iniquidades de saúde, tais como o desemprego, a falta de acesso à moradia digna, ao sistema de saneamento básico, a serviços de saúde e de educação de qualidade e a um meio ambiente protegido $^{(43)}$. As iniquidades em saúde podem ser caracterizadas como aquelas desigualdades de saúde que, além de sistemáticas e relevantes, são também evitáveis, injustas e desnecessárias $^{(44)}$. No contexto brasileiro, essas são consideradas um dos traços mais marcantes de nossa situação de saúde, estando relacionadas, principalmente, às formas como se organiza a nossa vida social, uma vez que as condições econômicas e sociais exercem um efeito importante sobre a saúde ${ }^{(43)}$. 
Ademais, a existência das iniquidades é potencializada pelo fato de o Brasil ser um país com elevadas taxas de concentração de renda. O componente mais importante para elucidar a situação geral de saúde de um país não é puramente explicado por sua riqueza total, mas, sim, pela maneira como esta riqueza é acessada pela população, em uma relação na qual iniquidades em saúde e distribuição de renda são expressas como grandezas de ordem inversamente proporcional ${ }^{(45)}$.

Em outras palavras, no caso do Brasil o fardo é duplo, pois, além de apresentar importante dicotomia na distribuição da riqueza, há grandes setores de sua população vivendo em condições de pobreza que não lhes permite ter acesso nem às mínimas condições e bens essenciais à saúde ${ }^{(41)}$. A situação contribui com o crescimento das desigualdades sociais, e, por conseguinte, gera novas iniquidades em saúde, em um típico e constante movimento de retroalimentação ${ }^{(46)}$.

Tal contexto de desigualdades não é um evento isolado ou recente. Ele apresenta caráter histórico-estrutural que se estende desde o período da colonização do continente até os dias de hoje ${ }^{(45)}$. Nesse contexto, pode-se destacar o século $\mathrm{XX}$, visto que o período caracterizou-se pela vigência de um modelo econômico que priorizou a modernização e industrialização com ênfase na forte concentração de renda. O projeto transformou o país, de predomínio rural à época, na décima economia do mundo. Entretanto, contribuiu, sobremaneira com a concentração de renda e exclusão social, acarretando um incremento abrupto dos níveis de desigualdade entre a população. O que, por sua vez, impactou nas condições de saúde, principalmente das populações mais pobres e vulneráveis a agravos decorrentes da própria condição de pobreza, do atraso social, das deficiências no atendimento de saúde e das precariedades nas condições ambientais, inclusive no que se refere à infraestrutura e saneamento básicos ${ }^{(22)}$.

O item saneamento pode ser apontado como uma das prerrogativas das políticas públicas com maior impacto no que se refere à garantia do direito a saúde de indivíduos e coletividades. Sanear quer dizer tornar são, sadio, saudável e, portanto, saneamento equivale ao investimento na própria condição para saúde, por meio de ações de abastecimento de água, esgotamento sanitário, drenagem e limpeza e tratamento de lixo. Desse modo, as políticas, ações e serviços de saneamento constituem componente elementar da infraestrutura de uma localidade, bem como, aspecto de grande valia no enfrentamento das iniquidades sociais e em saúde dos grupos ${ }^{(47)}$. 
Sabe-se que a importância do saneamento associada à saúde humana remonta às mais antigas culturas ${ }^{(48)}$. Por meio dele evita-se a contaminação e a proliferação de doenças, garantindo a preservação do meio ambiente e, ao mesmo tempo, proporcionando melhores condições de vida aos grupos populacionais, sendo a escassez de algum destes aspectos supracitados responsável por influenciar no processo saúde-doença, repercutindo negativamente na qualidade de vida e saúde da população.

Vários estudos ratificam tal proposição e, ainda, evidenciam a relação entre a ausência de infraestrutura básica e agravos à saúde, como diarreia, déficit no estado nutricional, infestações nematoides intestinais, infecção dos olhos ou pele, entre outros ${ }^{(49-51)}$. O próprio conceito de saneamento proposto pela Organização Mundial de Saúde ${ }^{(26)}$ também remete à aproximação entre os temas, saneamento e saúde, por meio da proposição de que o saneamento é o controle de todos os fatores do meio físico do homem, que exercem ou podem exercer efeitos nocivos sobre o bem-estar físico, mental e social das coletividades ${ }^{(51)}$.

No Brasil, no início da década de 1990 , a Lei.$^{\circ} 8.080^{(15)}$, que dispõe sobre o funcionamento dos serviços de saúde no país, reconheceu em seu artigo $3^{\circ}$ que a saúde tem como fatores determinantes e condicionantes, entre outros, o saneamento básico. Assim, além do embasamento advindo do conhecimento científico sobre o tema, também ocorreu o reconhecimento legal da existência de uma relação de causalidade entre condições inadequadas de saneamento básico e o quadro epidemiológico existente, o que evidencia a relevância para o campo da saúde pública de se preconizar a temática na orientação de seu planejamento, proposição e intervenções junto às coletividades.

Entretanto, para um grupo expressivo de brasileiros a realidade se distancia, e muito, do preconizado, sendo a infraestrutura básica considerada artigo raro em diversos segmentos populacionais, tanto nas periferias das cidades quanto no campo. Em nosso país, o saneamento básico se apresenta insuficiente e com grandes desigualdades de distribuição, principalmente nas populações menos favorecidas ${ }^{(52)}$, o que resulta em fator capaz de comprometer as ações em promoção da saúde voltadas para a garantia de cidadania e equidade.

Destarte, investir em saneamento pode ser considerado a principal forma de se reverter o quadro de iniquidades existente em nosso país, já que por meio das políticas públicas de saneamento pode-se reduzir o déficit nesse setor com prioridade para as populações em 
situação de maior vulnerabilidade social e ambiental, o que é imprescindível no que tange à melhoria na qualidade de vida e saúde das populações.

A problemática ora apresentada nos permite inferir que, mesmo o Brasil tendo aumentado seus investimentos em saneamento básico nos últimos anos ${ }^{(48)}$, muito ainda precisa ser caminhado na tentativa de superar os atuais entraves de nossa atual situação de saúde. É preciso que o Estado seja capaz de desenvolver políticas econômicas e sociais voltadas à redução dos riscos de doenças e outros agravos à saúde e à promoção do acesso universal e igualitário às ações e serviços públicos de saúde, e, assim, contribuir com a reversão deste preocupante quadro social de iniquidades ${ }^{(53)}$.

As populações outrora alijadas do acesso a bens e serviços, muitas vezes, permanecem excetuadas desse processo. Inegável é, portanto, que os grupos que foram historicamente excluídos, ainda enfrentam horizontes obscurecidos quanto à garantia do direito à saúde ${ }^{(54)}$. Os aglomerados suburbanos, incluindo as zonas rurais, concentram essa população caracterizada por estar à margem da organização interna das cidades e exposta às muitas iniquidades sociais existentes no país.

As comunidades rurais negras afro-brasileiras, denominadas quilombolas ou quilombos contemporâneos, bem ilustram o contex to descrito anteriormente e se caracterizam enquanto grupo étnico fortemente exposto às vulnerabilidades sociais. A conjuntura vivenciada pelos moradores Kalungas remanescentes de quilombos denota as consequências históricas do processo de escravidão e sua forma de libertação, que influenciou e ainda têm influenciado no acesso diferenciado deste grupo a bens e serviços. Muitos dos quilombolas Kalungas encontram-se abaixo da linha da pobreza e outros tantos até mesmo abaixo da linha da indigência ${ }^{(55)}$.

O território Kalunga é descrito, em dados do Governo Federal Brasileiro, como possuidor dos índices mais baixos de desenvolvimento humano do Estado de Goiás, sendo notórios os problemas relacionados à moradia, ao baixo nível educacional, à fragilidade e, até mesmo, à total ausência de serviços de infraestrutura ${ }^{(56)}$. Como os problemas relacionados com a insuficiência dos serviços básicos de saneamento, coleta e destinação adequada do lixo e condições precárias de moradia são tradicionalmente relacionados com a pobreza e com os espaços geográficos onde essas populações pobres residem, pode-se inferir que um dos mais 
importantes fatores determinantes da saúde da Comunidade Kalunga faz interface com as fragilidades nas suas condições de vida.

Por outro lado, a utilização do saneamento como instrumento de promoção da saúde pressupõe a superação dos entraves tecnológicos, políticos e gerenciais, o que tem dificultado a extensão dos benefícios aos quilombolas residentes em áreas rurais ${ }^{(57)}$ e contribuído com a exclusão e manutenção de desigualdades.

Assim, o hiato que se evidencia refere-se ao fato de que, apesar de o SUS ser comprometido com toda a população brasileira de modo universal, integral e equânime, ainda se constata a persistência de iniquidades em saúde vivenciadas pelos Kalungas, o que reflete a permanência de uma luta antiga por inclusão, bem como, pela garantia da não violação dos direitos sociais mais básicos à vida.

Neste sentido, a criação da Política Nacional de Saúde Integral da População Negra (PNSIPN) veio consolidar ações e planos voltados para a atenção à saúde da população negra, que ainda persiste sob uma situação de desigualdades ao longo da história. Assim, efetivar o direito humano à saúde da população negra é também um marco constituído pela luta para o estabelecimento de padrões de equidade étnico-raciais na política de saúde do país ${ }^{(58)}$. O movimento propõe ruptura com as condições de desigualdades instituídas que acabam por perpetuar, mesmo que de forma velada, a situação de exclusão e abandono de determinados grupos étnico-raciais, como é o caso da comunidade quilombola rural Kalunga.

De tal forma, a inquietação em desenvolver um estudo sobre as relações existentes entre saúde e as condições de vida, em especial, no que tange às questões sanitárias e epidemiológicas das comunidades rurais quilombolas, partiu da identificação de lacunas nas ações de promoção e prevenção em saúde, falta de políticas públicas ambientais voltadas principalmente a este contexto. A Constituição Federal de 1988 declara que a saúde é um direito de todos e um dever do Estado garantido mediante medidas políticas, sociais e econômicas; todavia, muitas vezes essas não atingem diretamente todas as camadas sociais, em especial nas áreas rurais.

Além disto, observa-se o reduzido número de estudos sobre essa temática, o que se constitui em fragilidade no campo da saúde pública no Brasil. Buscar a interação entre saúde e condições de vida, tendo como pano de fundos os Determinantes Sociais de Saúde (DSS), representa um desafio científico, dada a complexidade de elementos que envolvem tal relação. 
As ações insuficientes voltadas à saúde, ao saneamento e ao meio ambiente na sociedade atual, em especial nas comunidades rurais quilombolas, estão se tornando um problema cada vez mais evidente e que reclama investimentos em pesquisas e ações.

O exposto evidencia a pertinência da realização de estudos que, como este, estejam voltados para a caracterização das condições epidemiológicas e sanitárias das populações. Sua contribuição está na produção de informações, de forma a permitir o monitoramento das desigualdades sociais em saúde. Os achados provenientes desse tipo de abordagem investigativa podem ainda colaborar para a consolidação de avanços em saúde pública, pois viabilizam, no contexto específico e singular das comunidades, a avaliação da saúde, a identificação de iniquidades, associando-as a fatores condicionantes e determinantes, sejam sociais, econômicos, culturais ou ambientais.

No caso específico das comunidades quilombolas, o monitoramento dessas iniquidades e o estudo sistemático e aprofundado de seus determinantes possibilita a identificação de pontos mais sensíveis ao impacto de políticas públicas que buscam combatêlas. Para que essas políticas sejam mais efetivas é necessário, portanto, por um lado, aumentar os conhecimentos sobre determinantes sociais em saúde, suas hierarquias e mediações e, por outro, facilitar a incorporação desses conhecimentos na definição e implantação das políticas.

Essa tendência justifica-se porque, hoje em dia, além das ações de prevenção e assistência à saúde dos grupos populacionais, considera-se, cada vez mais importante, atuar sobre os fatores determinantes da saúde, em sua perspectiva de qualidade de vida. É essa a finalidade da promoção da saúde, que, além de constituir o principal elemento norteador de nosso sistema único de saúde, é, também, corroborada pelas propostas da Organização Mundial de Saúde e da Organização Pan-Americana de Saúde ${ }^{(59-60)}$. 


\section{CAPÍTULO 2}




\section{REFERENCIAL TEÓRICO}

\subsection{REFORMA SANITÁRIA}

Segundo Cohn $^{(61)}$, a expressão Reforma Sanitária não tem uma única significação conceitual, ela faz menção à caracterização das experiências de reformulação normativa e institucional no campo da assistência à saúde dos cidadãos, nos mais variados países do primeiro e do terceiro mundo, como a Itália, a Espanha, Portugal e o próprio Brasil.

Assim, em se tratando da contextualização do movimento pela Reforma Sanitária nos diferentes países, pode-se destacar toda uma conjuntura política, histórica e social. Após a Segunda Guerra, teve início um período reconhecido tanto pelo avanço científico e tecnológico quanto pelas mudanças nas estruturas sociais que acarretaram grande impacto nos bens sociais disponíveis. Tal momento histórico ficou conhecido como Estado de Bem Estar Social, caracterizado, nos países centrais, pela consolidação de reformas sociais e pelo investimento em políticas nesta área, voltadas para a consolidação tanto da cidadania quanto da efetivação de um novo patamar para os direitos sociais. Consolida-se, assim, um padrão de proteção social cujo principal sentido é o de promover a inclusão social sob a égide de um Estado provedor das condições mínimas de subsistência. Nos países capitalistas periféricos este movimento também teve grande repercussão. Porém, de forma mais desigual e em um padrão menos abrangente quando comparado ao movimento originário. Nestas regiões, tal movimento desenvolveu-se com o enfoque em um sistema de proteção pontual composto geralmente por sistemas previdenciários específicos e vinculados, principalmente, ao mercado formal de trabalho ${ }^{(62)}$.

A partir da década de 1960, começaram a aparecer os primeiros sinais de crise nos Sistemas de Bem Estar Social e no paradigma de 'proteção' que os sustentava, resultando em uma série de ajustes em relação à seguridade social. No cenário mundial, os anos 70 representaram o ápice desse processo de ajustamento, tendo como principal diretriz a estrita obediência ao princípio de racionalidade econômica, em detrimento dos impactos sociais por ele produzidos. Realidade que acarretou uma crescente subtração de direitos sociais consagrados no padrão do welfare state. A ideia em voga à época partia do princípio de que deveria haver uma compressão das despesas sociais, um Estado mínimo e cortes no orçamento público ${ }^{(63)}$. 
A conjuntura ora descrita de crise do welfare state em todo o Ocidente e o crescimento do chamado neoliberalismo, coincidiu com os anos de formulação e implantação do principal projeto do movimento pela Reforma Sanitária Brasileira - o Sistema Único de Saúde, SUS ${ }^{(63)}$.

No Brasil, manteve-se, desde os anos 30, uma configuração de Estado desenvolvimentista populista, não contemplado pela participação popular que corresponderia à versão latino-americana da hegemonia keynesiana da Europa, mas sem os direitos associados ao welfare state. O projeto desenvolvimentista que serviu para adjetivar o Estado brasileiro por mais de meio século foi sustentado por um bloco político conservador, contando com apoio dos partidários do liberalismo econômico e mantendo o seu caráter autoritário ${ }^{(64)}$.

Tanto durante o governo Vargas - 1930 a 1945 - quanto durante a ditadura militar 1964 a 1984 -, o modelo de proteção social se expande no país; contudo, nesses modelos não havia a participação da sociedade e os processos eram centralizados em grandes burocracias $^{(63)}$.

Em 1930, foi criado o Ministério da Educação e Saúde. As atenções dos governos, até então, estavam voltadas às ações de caráter coletivo, sendo a assistência médica organizada por algumas empresas na modalidade de benefício aos trabalhadores que contribuíam com a Previdência Social ${ }^{(65)}$. A partir dessa década a ênfase governamental começa a se voltar para a assistência médica individual ${ }^{(66)}$.

Sob a influência do Plano SALTE - Saúde, Alimentação, Transporte e Energia, em 1953 foi criado o Ministério da Saúde com o objetivo de se dedicar às atividades de caráter coletivo, tais como as campanhas e a vigilância sanitária. Assim, o sistema de saúde passou a ser formado pelo Ministério da Saúde, cuja atuação centrava-se nas ações de cunho coletivo e pela Assistência Médica da Previdência Social, na figura das instituições previdenciárias responsáveis pela assistência médica de caráter individual ${ }^{(63)}$. Esse modelo de assistência à saúde operava em modo centralizador, curativo e excludente, com acesso restrito aos trabalhadores com comprovação de vínculo empregatício ${ }^{(5)}$.

Em linhas gerais, eram vários problemas envolvendo as condições de saúde no país, como o aumento da mortalidade infantil, a epidemia de acidentes de trabalho, dentre outros $^{(63)}$. Ao contrário do que preconizava, o modelo de desenvolvimento adotado concentrou a riqueza e não distribuiu os benefícios sociais, repercutindo diretamente na saúde da população ${ }^{(5)}$. 
Na década de 1970, a política de saúde já se encontrava totalmente polarizada entre as ações de caráter coletivo a cargo do Ministério da Saúde, como vacinação, programas contra determinados agravos, vigilância epidemiológica e sanitária; e a assistência médica individual centrada no Instituto Nacional de Previdência Social - INPS, que teve sua origem no ano de 1966 por meio da fusão de todos os Institutos de Aposentadoria e Pensão, em uma iniciativa de uniformização e centralização da previdência social ${ }^{(65)}$. Durante esse período houve grande proliferação dos serviços privados de saúde ${ }^{(63)}$, haja vista que a assistência médica individualizada passou a ser dominante, sustentada porum modelo de estruturação política que privilegiou a privatização dos serviços de saúde ofertados. Realidade que, por conseguinte, repercutiu no estímulo ao desenvolvimento das atividades hospitalares ${ }^{(65)}$.

Em 1972, teve início uma ampliação da abrangência previdenciária. Primeiramente contemplaram-se as empregadas domésticas e trabalhadores rurais e, no ano seguinte, ocorreu a incorporação dos trabalhadores autônomos, que passaram a ser beneficiados pela cobertura de assistência médica no sistema de saúde. Entretanto, a maior cobertura dada pelo Sistema de Previdência Social em um mercado de saúde baseado em pagamentos a prestadores de serviço do setor privado (hospitais, clínicas, laboratórios, entre outros) acabou por favorecer um desequilíbrio de gastos nesse sistema ${ }^{(67)}$.

Assim, de um modo geral, pode-se constatar que o modelo privatista de assistência não foi capaz de alterar o perfil de morbimortalidade da população brasileira e entrou em crise. Isto aconteceu, principalmente, devido ao aumento dos custos, que dificultava a expansão da rede, à ausência de critérios para a compra de serviços e ao alto grau de centralização e fragmentação das ações dos dois Ministérios, Saúde e Previdência ${ }^{(68)}$.

Com o fim do 'milagre econômico', em meados da década de 1970, a crise fiscal do Estado foi acrescida ao cenário de precariedade nas condições de vida das camadas populares e de problemas de saúde decorrentes dessas condições, tais como: insatisfatório nível de atendimento médico com grandes filas, concentração do atendimento em hospitais, falta de acesso a remédios e tecnologia, dentre outros.

A importância de se repensar a política de saúde ficou cada vez mais evidente, e, como que em resposta, esta década pode ser considerada o marco temporal no qual as lutas da população por saúde adquiriram maior consistência e consequências para as políticas de saúde no $\operatorname{Brasil}^{(5)}$. 
O breve panorama apresentado permite inferir que o movimento pela Reforma Sanitária surgiu da indignação de setores da sociedade sobre o preocupante quadro do setor Saúde. Apesar da década de 1970 ser marcada pelo aumento da pobreza em um contexto de repressão, a luta pela democratização da saúde surge neste cenário, por meio de uma mobilização política da sociedade civil, composta pelos mais diversos atores sociais em um movimento de resistência ao autoritarismo imposto pelo governo dos militares ${ }^{(63)}$.

Nesse mesmo período, foram iniciadas as discussões acerca dos limites e possibilidades das propostas de reforma do ensino e da prática médica, principalmente entre os docentes dos Departamentos de Medicina Preventiva e Social ${ }^{(62)}$. Entre este grupo houve o fomento de reflexões críticas acerca das determinações econômicas, sociais e políticas que marcavam o exercício da Medicina em uma conjuntura social fortemente marcada pela capitalização e privatização da assistência médica previdenciária, eixo da política de saúde do regime autoritário ${ }^{(64)}$.

Assim sendo, na saúde, a agenda pós-welfare configurou-se em resposta liberal conservadora (ou neoliberal) a esta crise econômica dos anos 1973-1975, orientando as reformas sanitárias ${ }^{(69)}$. Vários estudos que comprovavam o prejuízo causado pelo modelo econômico vigente começaram a circular, denunciando os efeitos do modelo sobre a saúde da população e oferecendo propostas alternativas ao sistema vigente de saúde ${ }^{(5)}$. Essa crise do modelo de assistência do sistema de saúde foi favorecida pela desordem financeira do Estado, pela recessão na América Latina e pelo processo de redemocratização, que colocou novas exigências e demandas à dívida social ${ }^{(68)}$.

Sobre isto, Fleury ${ }^{(70)}$ complementa apontando que a construção do projeto da reforma sanitária modelou-se a partir da "noção de crise: crise do conhecimento e da prática médica, crise do autoritarismo, crise do estado sanitário da população, crise do sistema de prestação de serviços de saúde".

Foi no governo do General Ernesto Geisel (1974-1979) que a ditadura deu os primeiros sinais de crise, ilustrados nos índices econômicos negativos que se refletiram no campo político e social ${ }^{(63)}$.

No ano de 1974 surgiram o Plano de Pronta Atenção - PPA e o Fundo de Apoio ao Desenvolvimento Social para enfrentar a crescente demanda curativa em saúde. Na época 
grandes investimentos continuaram sendo feitos, privilegiando a assistência médica em detrimento das ações preventivas ${ }^{(65)}$.

Em 1975, o Sistema Nacional de Saúde foi regulamentado enquanto primeira tentativa de regulamentação do papel dos municípios na política de saúde. Contudo, tal experiência já nasceu fadada ao insucesso, uma vez que não havia um sistema propriamente dito e as ações de saúde se mantinham fragmentadas, sem nenhuma integração. A saúde coletiva era considerada um direito de todos e a assistência médica hospitalar individualizada direito apenas dos trabalhadores contribuintes do Sistema Nacional de Previdência Social, cabendo ao Ministério da Saúde a responsabilidade pela formulação das políticas públicas e o desenvolvimento das ações coletivas; ao Ministério da Previdência e Assistência Social a realização da assistência médica pelo INAMPS - Instituto Nacional de Assistência Médica e Previdência Social; ao Ministério da Educação a formação de recursos humanos para a saúde e a prestação de serviços nos hospitais universitários; ao Ministério do Interior as ações de saneamento e, por fim, ao Ministério do Trabalho a atenção frente à higiene e segurança do trabalho $^{(71)}$.

A baixa prioridade dada às ações de saneamento e a medicina preventiva, acrescidos do volume de recursos empregados com a medicina curativa, potencializaram a fragilidade do sistema previdenciário, ratificando a necessidade de se buscar caminhos alternativos ao período autoritário $^{(65,5)}$.

Neste sentido, em fins da década de 1970, com o processo de redemocratização que se deu por meio de uma abertura política lenta e gradual, houve a possibilidade de inclusão neste contexto de novos atores sociais: estudantes, professores universitários, setores populares e entidades de profissionais de saúde, que passaram a defender mudanças no setor saúde a partir das ideias difundidas pelo Movimento pela Reforma Sanitária Brasileira - MRSB ${ }^{(64)}$.

Ou seja, no próprio interior da política estatal de saúde surgiram questionamentos ao modelo, iniciando um movimento intelectual e político de crítica ao mesmo ${ }^{(65)}$. Santos ${ }^{(72)}$ corrobora com o proposto e acrescenta ênfase na aproximação entre os críticos do modelo de saúde vigente e o cenário político à época:

"A difusão das propostas de Medicina Comunitária, com apoio da Organização Mundial de Saúde, ocorrida na década de 70, forçou a penetração do debate no interior do Estado Brasileiro, por um lado. Por outro lado, a movimentação de setores da Sociedade Civil, ligados à área da Saúde, dirigidos taticamente pelo PCB, articulou relação Saúde e Democracia, imprimiu o eixo do debate, promovendo a organização de setores progressistas e de esquerda de 
profissionais de saúde pública no, posteriormente, denominado Movimento Sanitário, inspirado na Reforma Sanitária Italiana".

Destarte, a transição para o regime democrático desenvolveu-se em um clima de grande expectativa de transformação do padrão de desenvolvimento econômico e social. No âmbito da saúde, o processo de redemocratização culminou no fortalecimento do movimento pela Reforma Sanitária Brasileira, caracterizado por sua sustentação em base conceitual e produção teórico-crítica ${ }^{(73)}$.

O movimento sanitário não é um grupo de interesses e nem é formado por grupos de interesses [...]. O que o caracteriza enquanto movimento é o fato de ele aglutinar, além de indivíduos, entidades de diferentes naturezas funcionais, organizacionais e políticas, com uma proposta ético-política visando interesses coletivos [...]. O movimento se identifica como condutor das aspirações de grupos de consumidores, de usuários dos serviços de saúde enquanto cidadãos ${ }^{(74)}$.

Destaca-se, ainda, que tal proposta de mudança do sistema foi incorporada enquanto agente norteador ao conjunto de princípios e diretrizes da Reforma Sanitária Brasileira. Esta adotou perspectiva de fundamentação do novo modelo de sistemas de saúde baseados nos princípios da universalidade, integralidade e equidade, ao tempo em que se propunha a constituição de uma rede descentralizada, hierarquizada e integrada de serviços ${ }^{(73)}$. Assim, o ideário de luta pela saúde pública desenvolveu-se passo e passo, com a luta pela democracia e contra o modelo econômico vigente, em um movimento que envolveu intelectuais, profissionais de saúde, parcela da burocracia, organizações populares e sindicais ${ }^{(72)}$.

Esse movimento destinou-se a orientar as estratégias de ação política visando à reversão da lógica prevalecente no setor saúde, ou seja, assumiu o caráter de ação pública voltada para a construção de uma proposta de ideário governamental de eficiência, eficácia e efetividade, no sentido de superação do padrão centralizador, concentrador, autoritário, burocrático, privatizante e financeiramente autossustentado, reconhecidamente fracassado, característico do período anterior ${ }^{(73)}$.

A década de 1980 se caracterizou pelo vigoroso processo de redefinição do padrão de intervenção do setor público em toda a área social, especialmente na saúde. O processo não foi retilíneo e teve inúmeros avanços e retrocessos. Nos primeiros anos desse período, a crise financeira consolidou-se em grande entrave da previdência social, principal fonte de financiamento do setor saúde, fato que demandou drásticas restrições dos gastos previdenciários com assistência médica e alimentou a proposta de uma ampla reestruturação da saúde ${ }^{(5)}$. 
Em caráter propositivo pelos escalões do Ministério da Saúde, vieram a público alternativas de fortalecimento do setor público de saúde e de uma nova forma de remuneração, Programa Nacional de Serviços Básicos de Saúde - PREV-SAÚDE, na compra dos serviços privados de assistência médica. A estratégia defendeu a reestruturação do setor a partir da conversão da rede básica de serviços em porta de entrada do paciente no serviço de saúde, vislumbrando-se tanto a universalização e racionalização do atendimento em saúde, quanto a desconstrução do modelo hospitalocêntrico de atendimento. Entretanto, tal projeto sofreu algumas reescritas, criou celeumas, mas não foi efetivado ${ }^{(61)}$.

Em 1981 foi criado o Conselho Consultivo de Administração de Saúde Previdenciária - CONASP, que, logo no ano seguinte, foi o responsável pela apresentação e aprovação do Plano de Reorientação da Assistência à Saúde no âmbito da Previdência Social. Tal Plano do CONASP tinha entre os seus objetivos a melhoria da qualidade da assistência à saúde, a cobertura dos serviços de forma igualitária para a população rural e urbana, o planejamento da assistência à saúde de acordo com parâmetros pré-definidos e o aumento da produtividade com a racionalização dos serviços ${ }^{(75)}$.

Dentre as propostas de ação do referido plano de reorientação, evidenciou-se o Programa das Ações Integradas de Saúde, que em seguida foi transformado em estratégia Ações Integradas de Saúde - AIS ${ }^{(76)}$. Esta, pois, propunha modificações substanciais no setor, por meio da otimização dos serviços públicos de saúde, com vistas ao atendimento de uma demanda cada vez maior por assistência médica individual. De maneira geral, as AIS objetivavam integrar e racionalizar o atendimento médico tornando-os serviços, independentemente dos níveis de complexidade, mais acessíveis a população ${ }^{(75)}$.

Então, a partir de 1983, foram assinados com as Unidades da Federação os Convênios AIS, por meio dos quais a previdência social era responsável por repassar recursos para os estados, e estes para os municípios, cabendo às respectivas redes públicas de serviços o atendimento em saúde também aos previdenciários ${ }^{(76)}$.

Além desses embriões de caráter de universalidade e municipalização, o Plano CONASP propôs que os serviços adquiridos pelo INAMPS junto à rede privada fossem pagos por especificações do tipo Autorização de Internação Hospitalar, nas quais seria descrito todo o cálculo do custo global do procedimento médico realizado. Outra mudança estrutural no sistema de saúde oriunda desse processo diz respeito ao fato de que, nessa época, o INAMPS 
passou a dar aos trabalhadores rurais, até então assistidos somente por hospitais conveniados com o FUNRURAL, um tratamento equivalente àquele prestado aos trabalhadores urbanos ${ }^{(61)}$.

A conquista da democracia em 1985 possibilitou a realização da VIII Conferência Nacional de Saúde no ano seguinte. Nesse evento reafirmou-se o reconhecimento da saúde como um direito de todos e dever do Estado, recomendando-se a organização de um Sistema Único de Saúde - SUS descentralizado, com atribuições específicas para a União, Estados e Municípios, e democrático, garantindo a participação social na formulação das políticas de saúde, no acompanhamento e na avaliação ${ }^{(64)}$.

Em 1986, o Ministério da Saúde convocou a VIII Conferência Nacional da Saúde e as organizações da sociedade civil foram convidadas a participar de sua realização. O tema central da Conferência foi 'Saúde Dever do Estado e Direito do Cidadão', versando sobre a reformulação do Sistema Nacional de Saúde e o financiamento do setor ${ }^{(5)}$.

Desse modo, a VIII Conferência Nacional de Saúde representou inegavelmente um marco, pois introduziu a sociedade no cenário da discussão de saúde. A participação de aproximadamente 5000 pessoas, dentre as quais mil delegados, incluídos representantes da Sociedade Civil, exemplificou a diversidade de atores envolvidos neste movimento. Indiscutivelmente, os debates saíram dos fóruns específicos (Associação Brasileira de Saúde Coletiva - ABRASCO, Centro Brasileiro de Estudos de Saúde - CEBES, Medicina Preventiva e Saúde Pública) e a questão saúde transbordou a análise setorial referindo-se à sociedade como um todo na proposta, não somente do Sistema Único, mas da Reforma Sanitária $^{(12)}$. Evidenciou-se o consenso de que para o setor de saúde no Brasil não era suficiente uma mera reforma administrativa e financeira, mas sim uma mudança em todo o arcabouço jurídico-institucional vigente, que contemplasse a ampliação do conceito de saúde segundo os preceitos da Reforma Sanitária ${ }^{(77)}$.

Em outras palavras, a VIII Conferência Nacional de Saúde, por tudo que galgou no processo de repensar o sistema de saúde, tornou-se um marco da redemocratização do setor, especialmente para as relações entre Estado e sociedade civil. Ela pode ser apontada como principal responsável pelas novas formas de conceber e organizar o sistema de saúde brasileiro $^{(5)}$.

Assim, a referida Conferência consagrou uma concepção ampla da Saúde, entendida como resultante das condições de alimentação, habitação, educação, renda, meio ambiente e 
trabalho, avançando a consciência sobre o propósito da Reforma Sanitária, como também o direito do cidadão à saúde a ser garantido pelo Estado ${ }^{(72)}$. Ela foi a responsável pelas discussões que resultaram na formalização das propostas do Movimento pela Reforma Sanitária Brasileira, ensejando mudanças baseadas no acesso universal à saúde, acesso igualitário, descentralização acelerada, e ampla participação da sociedade. Nesta Conferência já se apontava para a municipalização como forma de se executar a descentralização. As bases do atual SUS foram delineadas por esta Conferência, cujo relatório final subsidiou decisivamente a Constituição Federal de 1988 nos assuntos de saúde ${ }^{(12)}$.

No final da década de 1980, o INAMPS adotou uma série de medidas de ampliação da cobertura à clientela usuária dos serviços públicos de saúde. Por exemplo: o fim da exigência da Carteira de Segurado do INAMPS para o atendimento nos hospitais próprios e conveniados da rede pública. Esse processo culminou com a instituição do Sistema Unificado e Descentralizado de Saúde - SUDS, implementado por meio da celebração de convênios entre o INAMPS e os governos estaduais ${ }^{(78)}$.

Os convênios SUDS começaram a ser assinados com as várias Unidades da Federação a partir de meados de 1988, prevendo, da mesma forma que as AIS, financiamento tripartite esferas federal, estadual e municipal -e o reforço da autonomia desses últimos dois níveis na gestão da saúde. Com isto, o sentido da universalização do acesso à saúde via fortalecimento do setor público de serviços mais uma vez pôde ser identificado ${ }^{(75)}$.

A Constituição Federativa Brasileira de 1988, em suas definições relativas ao setor saúde, ratifica essa proposição. Enquanto primeira e grande conquista do Movimento da Reforma Sanitária, a Constituição de 1988 expressa, de maneira clara, a universalidade da cobertura do Sistema Único de Saúde ao conceituar no Art. 196 que "a saúde é direito de todos e dever do Estado" (13). Essa Carta Constitucional ficou conhecida como a 'Constituição Cidadã', pois inovou em relação às formulações legais anteriores, demonstrando certo avanço no que tange aos direitos sociais e às condições de cidadania, especialmente no campo da saúde $^{(9)}$.

Em 07 de março de 1990 ocorreu a publicação do Decreto n. ${ }^{\circ}$ 99.060/1990, que pode ser destacado como relevante passo em direção ao cumprimento da determinação constitucional de construção do Sistema Único de Saúde. A partir de tal promulgação, o INAMPS foi transferido do Ministério da Previdência para o Ministério da Saúde ${ }^{(61)}$ 
Mais tarde, em setembro desse mesmo ano, o país passou a dispor de um sistema público de saúde único e universal, a partir da promulgação da Lei n. ${ }^{\circ}$ 8.080/90: o Sistema Único de Saúde, com comando único em cada esfera de governo e com o Ministério da Saúde como gestor no âmbito da União. Nessa lei, em seu Capítulo II - Dos Princípios e Diretrizes, Art. $7^{\circ}$, há a consolidação do princípio da universalidade do sistema de saúde brasileiro, uma vez que estabelece entre os princípios do SUS a "universalidade de acesso em todos os níveis de assistência" ${ }^{(15)}$. Assim, em linhas gerais, no bojo das mudanças advindas do movimento da Reforma Sanitária, pode-se identificar certa tendência à cobertura universal no sistema de saúde brasileiro, anterior à instituição, propriamente dita, do Sistema Único de Saúde, que se deu por meio da aprovação da Lei n. ${ }^{0} 8.080$ - Lei Orgânica da Saúde ${ }^{(78)}$.

Nesse sentido, o grande desafio do MRSB passou a ser promover a transição do sistema desintegrado, no que diz respeito à articulação das esferas de governo, e centralizado, ora em serviços médicos hospitalares privados, ora em programas verticalizados, para outro sistema com comando único em cada esfera de governo. Isto tudo por meio uma contínua tarefa de proposição construtiva, e não mais de resistência, como nas décadas anteriores ${ }^{(77)}$.

Fleury $^{(9)}$ bem sintetiza as concepções envoltas no MRSB ao apontar que a reforma sanitária caracteriza-se como o projeto e a trajetória de constituição e reformulação de um campo de saber, uma estratégia política e um processo de transformação institucional.

Na década de 1990, o que se pode observar foi que a consolidação do SUS, especialmente no que tange ao processo de regulamentação do Sistema, contou com a participação de novos atores sociais, além dos já inclusos desde o Movimento Sanitário. Entram em cena os Secretários Municipais de Saúde, liderados pelo Conselho Nacional de Secretários Municipais de Saúde - CONASEMS e os Secretários Estaduais de Saúde, liderados pelo Conselho Nacional de Secretários de Saúde - CONASS ${ }^{(5)}$.

Assim, como forma de regulamentar a implantação, estruturação e consolidação do SUS, o Ministério da saúde optou em lançar mão de instrumentos normativos que foram publicados com o objetivo de regular as transferências de recursos financeiros da União para os Estados e Municípios, o planejamento das ações em saúde e os mecanismos de controle social. Esses instrumentos são conhecidos como Normas Operacionais Básicas - NOB, responsáveis pela criação de condições privilegiadas de negociação para viabilizar a descentralização e, consequentemente, para a construção e aprimoramento do SUS ${ }^{(77)}$. Tais 
normas operacionais se destacam pela importância na orientação do novo modelo de atenção à saúde, inclusive nos aspectos de financiamento.

Com o objetivo de viabilizar uma crescente operacionalização das ações do SUS, em 13 de setembro de 2000 foi promulgada a Emenda Constitucional 29, que trata da garantia constitucional do financiamento do sistema a partir dos impostos pagos, deduzidas as transferências entre governos ${ }^{(65)}$.

A partir de um percurso que já ultrapassa três décadas, pode-se inferir que o SUS resultou no próprio fortalecimento da democracia brasileira e na garantia de importantes conquistas para os cidadãos. É inegável que o funcionamento do SUS, desde a sua implantação até os dias de hoje, fez com que a área de saúde pudesse ser considerada uma das mais democráticas, pois, além de comportar um alto grau de participação social, universalizou-se o direito à saúde, apontando para a garantia do pleno acesso aos serviços sem quaisquer critérios de exclusão ou discriminação ${ }^{(79)}$.

Contudo, o que merece atenção por parte dos governantes e da sociedade como um todo, é o fato de que, apesar dos avanços consideráveis ainda é possível identificar inúmeros desafios pela frente, em especial, no sentido da garantia constitucional do direito universal à saúde.

No entanto, ainda são notórios os incontáveis vieses em relação às vivências cotidianas de parcelas minoritárias da população brasileira, como é o caso dos moradores rurais de comunidades quilombolas. O quadro de precariedade nas condições de vida e saúde deste grupo populacional reflete o quanto o princípio de igualdade está sendo comprometido, bem como, indica o próprio Sistema Único de Saúde, por meio de uma atuação efetiva e de qualidade, como agente promotor de equidade e justiça social, uma vez que a saúde se aproxima da ideia central de qualidade de vida e se constitui em um dos elementos fundantes da cidadania.

\subsection{SOBRE OS QUILOMBOLAS}

As demandas das comunidades rurais negras afro-brasileiras, denominadas quilombolas ou quilombos contemporâneos, fazem parte das questões emergenciais da sociedade brasileira, principalmente no que concerne ao acesso e à atenção em saúde ${ }^{(58)}$. Os remanescentes das comunidades dos quilombos são núcleos populacionais cuja origem está 
atrelada, inquestionavelmente, à própria história do Brasil, em especial ao período escravocrata.

Estima-se que o número de escravos africanos importados pelas Américas passou de 10 milhões, sendo que somente o Brasil recebeu por volta de $40 \%$ deste quantitativo ${ }^{(80)}$. Isso se deu, pois, no sistema escravista, a mão-de-obra escrava constituiu-se na base de toda a economia nacional, movimentando engenhos, minas, cidades e fazendas. É consenso que o Brasil foi o maior importador de escravos nas Américas, sendo o porto do Rio de Janeiro, de grande destaque na redistribuição dos cativos enquanto mercadoria. Grande parte destas pessoas que foram escravizadas era, por ocasião do comércio negreiro transatlântico, destinada a compradores no interior do país, incluindo no Estado de Goiás ${ }^{(81)}$.

Diante o cenário da sociedade escravocrata brasileira, dentre outras formas de resistência, a fuga e a formação de grupos de escravos fugidos foi a que se tornou mais comum $^{(82)}$. Estas formas particulares de organização social, os quilombos, se caracterizaram por ocupar espaços geográficos estratégicos e de difícil acesso, localizados notadamente nas áreas rurais e apresentando um relativo grau de isolamento e clandestinidade.

O "kilombo" possuía organização própria com características idiossincrásicas de práticas culturais, agricultura e pecuária resultantes da mescla das diversas populações. Seus membros desenvolveram uma relação específica com a natureza ${ }^{(83)}$, sendo a terra seu fundamental meio de sobrevivência. Viver nos quilombos equivalia a arar e cultivar a terra para dela extrair os recursos necessários à vida e também dela fazer a sua moradia e nela reconstruir seu suporte cultural, numa perspectiva de autosobrevivência ${ }^{(84)}$.

A palavra "quilombo" tem sua origem na língua bantu ('kilombo') e em sua etimologia quer dizer acampamento guerreiro na floresta. Seu significado no Brasil tem influência destes povos, cujos membros foram aqui escravizados, em especial, os grupos iunda, ovimbundu, mbundu, kongo, imbangala, entre outros, vindos de Angola e Zaire ${ }^{(83)}$.

A administração colonial também teve participação no processo de incorporação e popularização do vocabulário 'quilombo' à linguagem local, uma vez que a expressão era empregada em leis, relatórios, atos e decretos, para se referir às unidades de apoio mútuo, criadas pelos rebeldes ao sistema escravista e às suas reações, organizações e lutas pelo fim da escravidão no País ${ }^{(6)}$. Seu primeiro registro data de 1790, quando o Conselho Ultramarino, reportando-se ao rei de Portugal, valeu-se do vocábulo ao descrever "toda habitação de negros 
fugidos que passem de cinco, em parte despovoada, ainda que não tenham ranchos levantados nem se achem pilões neles", sendo, a partir de então, seus membros chamados de quilombolas, calhambolas ou mocambeiros ${ }^{(82)}$.

Este conceito, com o passar dos anos, se consolidou no seio da sociedade brasileira, constituindo-se em questão relevante e influenciando, significativamente, uma geração de estudiosos da temática quilombola até meados dos anos 70. Como traço comum entre esses autores, pode-se citar o fato de atribuírem aos quilombos um tempo histórico passado associado ao período em que vigorou a escravidão no Brasil enquanto expressão de resistência ao sistema escravista, vez que, diante da condição de escravidão, a formação de grupo de escravos fugitivos tornou-se comum.

Entretanto, esta abordagem não contemplou, em sua abrangência, a diversidade das relações entre escravos e sociedade escravocrata e nem as diferentes formas pelas quais os grupos negros apropriaram-se da terra, formando os quilombos ${ }^{(85)}$. Apesar de haver certa primazia na concepção de quilombo, a qual diz se tratar de um grupo de negros fugidos e isolados em territórios distantes, atualmente um conceito mais amplo é atribuído pelos historiadores.

Diversos trabalhos mais recentes têm demonstrado que não se trata de um grupo populacional pretérito nem tampouco de um grupo cuja economia interna fora organizada de modo totalmente isolado das economias regionais da Colônia, do Império e da República. Em geral existiu, paralelamente à formação do aparato de perseguição aos fugitivos, uma rede de informações que ia desde as senzalas até muitos comerciantes locais que tinham grande interesse na manutenção desses núcleos quilombolas, uma vez que lucravam com as trocas de produtos agrícolas e, até mesmo, em alguns casos, de ouro garimpado clandestinamente em rios, por produtos que não eram produzidos no interior do quilombo ${ }^{(85)}$.

As comunidades de ex-escravos se organizavam de diferentes formas, de acordo com o número de habitantes. Segundo Moura ${ }^{(86)}$, os quilombos de pequeno porte, geralmente, possuíam estrutura simples, sendo caracterizados principalmente enquanto grupos armados. Ao contrário, os maiores, de grande porte, eram mais complexos e se organizavam constituindo formas de governo, religião, propriedade, família e economia. Normalmente, os quilombos que mais cresciam eram os beneficiados por condições favoráveis como maior isolamento geográfico, melhor fertilidade do solo e possibilidade de recrutar novos membros. 
A esses grupos, rotineiramente juntavam-se outros elementos igualmente oprimidos como negros alforriados, fugitivos do serviço militar, índios, mulatos e negros marginalizados, todos interessados em buscar exílio frente ao regime escravocrata.

Após a abolição da escravatura, 13 de maio de 1888, vários quilombos continuaram recebendo novos membros, fruto, principalmente, da não alteração do status de "invisibilidade" social entre grupos e/ou famílias negras. A realidade foi resultado de todo um contexto de marginalização produzido historicamente e atrelado ao negro, cuja ideologia ignorou os efeitos da escravidão na sociedade brasileira, assim como os efeitos da inexistência de uma política governamental que regularizasse as posses de terras, extremamente comuns à época ${ }^{(87)}$.

Assim, apesar dos quilombos terem surgido na época escravagista, muitos deles formaram-se ou ampliaram-se após a assinatura da Lei Áurea. Pois, muito embora a Lei extinguisse a escravidão, não considerou a questão da redistribuição de terras, de modo que as organizações quilombolas continuaram a ser a única forma de viver em liberdade ${ }^{(88)}$.

Como exemplo desta resistência ao regime escravocrata, destaca-se o Quilombo dos Palmares por sua historiografia como o maior e o mais duradouro quilombo no Brasil. Palmares, localizado em meio a floresta de palmeiras, na serra da Barriga, atualmente pertence ao Estado de Alagoas, surgiu no século XVII com escravos fugidos, principalmente, dos engenhos de açúcar pernambucanos. $\mathrm{O}$ assentamento, que chegou a contar com nove aldeias - Macaco, Andalaquituche, Subupira, Dambrabanga, Zumbi, Tabocas, Arotirene, Aqualtene e Amaro -, era organizado como um pequeno Estado, existindo leis e normas que regulamentavam a vida dos seus habitantes. As decisões eram tomadas em assembleias, da qual participavam todos os adultos, sendo aceitas por resultarem da vontade coletiva, sem deixar de existir a figura das lideranças, dentre as quais evidencia-se Ganga-Zumba e $\mathrm{Zumbi}^{(89)}$.

A partir da década de 1980, a temática quilombola e suas interfaces retornam à cena política nacional devido à ação política de movimentos sociais negros, realidade que culmina na revisão no próprio conceito de quilombo, que deixou de ser visto como comunidades pretéritas $^{(90)}$, e na identificação de quilombos no meio rural do Brasil contemporâneo.

Assim, o caráter reducionista que associava as comunidades quilombolas, exclusivamente, a um tempo histórico passado com formação a partir de refúgio de escravos 
fugitivos, é complementado pela concepção de que os grupos considerados atualmente como remanescentes de comunidades de quilombos se constituíram a partir de uma grande diversidade de processos. Tais como: dissolução de fazendas por enfraquecimento da atividade econômica, abandono dos escravos pelos senhores, heranças, doações, recebimento de terras como pagamento de serviços prestados ao Estado, prestação de serviços em períodos de guerras, compra de terras (tanto durante a vigência do sistema escravocrata quanto após a sua extinção), simples permanência nas terras que ocupavam e cultivavam no interior das grandes propriedades, bem como resultado de agrupamentos criados e/ou ampliados, após a abolição da escravatura no Brasil ${ }^{(91)}$.

O marco legal, relativo a essas comunidades quilombolas atuais, se estabeleceu na Constituição Federal de 1988, no Artigo 68, do Ato das Disposições Constitucionais Transitórias, no qual foi delegado à Fundação Cultural Palmares, entidade vinculada ao Ministério da Cultura, os cuidados de todas as questões referentes a quilombos. A partir de então, esse grupo social tem recebido atenção mais destacada das entidades governamentais e sociedade civil. O ADCT estabelece que: "aos remanescentes das comunidades dos quilombos que estejam ocupando suas terras, é reconhecida a propriedade definitiva, devendo o Estado lhes emitir títulos respectivos”. Além disso, os artigos 215 e 216 da CF/1988, que tratam do patrimônio cultural brasileiro, asseguram a proteção às manifestações afrobrasileiras e o tombamento de documentos e sítios detentores de "reminiscências históricas dos antigos quilombos" ${ }^{(82)}$.

Em 1994, a Fundação Cultural Palmares formulou um novo conceito para os quilombos, que passaram a ser vistos como "toda comunidade negra rural que agrupe descendentes de escravos vivendo de uma cultura de subsistência e onde as manifestações culturais têm forte vínculo com o passado"(92).

A referida definição de quilombos está baseada na autoatribuição, com trajetória histórica própria, dotada de relações territoriais específicas, com a presunção de ancestralidade negra, relacionada com a resistência à opressão histórica sofrida ${ }^{(93)}$. Ou seja, convencionou-se interpretar que o que caracteriza uma atual comunidade quilombola é sua descendência do campesinato negro cuja origem retoma ao período escravocrata:

\footnotetext{
"Contemporaneamente, portanto, o termo não se refere a resíduos ou resquícios arqueológicos de ocupação temporal ou de comprovação biológica. Também não se trata de grupos isolados ou de uma população estritamente homogênea. Da mesma forma nem sempre foram constituídos a partir de movimentos insurrecionais ou rebelados, mas, sobretudo, consistem em grupos que
} 
desenvolveram práticas de resistência na manutenção e reprodução de seus modos de vidas característicos num determinado lugar,"(94).

Deste modo, o termo remanescente de quilombo ou quilombolas, como se divulga popularmente, indica "a situação presente dos segmentos negros em diferentes regiões e contextos e é utilizado para designar um legado, uma herança cultural e material que lhe confere uma referência presencial no sentimento de ser e pertencer a um lugar específico"(85).

Esses grupos sociais têm uma identidade étnica que os distingue do restante da sociedade, a pluriatividade está presente em um sistema de produção que combina a prática da agricultura, pecuária, caça, pesca, extrativismo vegetal, produção de artesanato e um processamento mínimo de vegetais. Os quilombolas contemporâneos caracterizam-se, assim, pelo arranjo dos sistemas de produção dependentes, principalmente, da potencialidade produtiva do meio ambiente e pelo modo de vida marcado pela valoração das tradições culturais e religiosas dos antepassados ${ }^{(58)}$.

Todas as regiões brasileiras apresentam áreas remanescentes de quilombos, estando catalogado, por todo o país, um total de mais de 2000 comunidades, que apresentam panoramas regionais bem diferenciados ${ }^{(90)}$. As comunidades remanescentes de quilombo constituem parte das comunidades brasileiras tradicionais que enfrentam grandes dificuldades para se manterem em suas terras. Fato é que apenas a minoria deste grupo possui o título definitivo de propriedade, embora, este seja um direito assegurado desde $1988^{(91)}$.

Há divergências em relação ao número exato de comunidades remanescentes de quilombos no Brasil. Por exemplo, de acordo o Cadastro Municipal dos Territórios Quilombolas, realizado em 2005 pelo Centro de Cartografia Aplicada e Informação Geográfica da Universidade de Brasília, existem 2.228 comunidades, das quais apenas 70 estão com a situação fundiária regularizada. E, segundo Anjos e Cipriano ${ }^{(95)}$, este quantitativo é um pouco maior, com a soma de 2.790 comunidades remanescentes de quilombos em todo território nacional.

Ambos os levantamentos descrevem que nas regiões Norte, Nordeste e Sudeste encontram-se a maioria dessas comunidades, enquanto que uma menor parcela se localiza nas regiões Centro-Oeste e Sul. Em valores por região, tem-se que a região Nordeste conta com 1672 registros, seguida pela região Norte com 442. No Sudeste, e o Sul e no Centro-Oeste encontram-se 375, 170 e 131 registros, respectivamente. Dentre as comunidades remanescentes de quilombo da região Centro-Oeste, a comunidade quilombola Kalunga é a 
mais importante em termos numérico e histórico e está entre as maiores do país ${ }^{(95)}$, sendo oficialmente reconhecida pelo Governo Federal no ano de 2000, e certificada pela Fundação Cultural Palmares em 2005.

\subsection{A COMUNIDADE QUILOMBOLA KALUNGA EM GOIÁS}

A palavra "Kalunga" ou calunga é de origem africana (bantu) e apresenta diferentes significados e interpretações. Para os africanos, entre os povos chamados congo ou angola, por exemplo, Kalunga era uma palavra mágica ligada às divindades e às crenças religiosas. Ela se referia ao mundo dos ancestrais. Para eles Kalunga era o nome do lugar de passagem (grande rio), por onde o homem podia entrar em contato com a força de seus antepassados. Kalunga era o que tornava uma pessoa ilustre e importante, porque mostrava que ela tinha incorporado em sua vida a força de seus antepassados.

Destarte, quando esses africanos foram aprisionados e trazidos para o Brasil, a palavra Kalunga foi incorporada ao vocabulário local, sendo empregada para se referir aos próprios escravos, por ser esta uma expressão de uso comum entre os africanos. E a partir deste uso, a palavra calunga adquiriu outro significado, passando a denotar coisa pequena e insignificante. Por outro lado, a palavra calunga também faz alusão a uma planta da família das simarubáceas (Simaba ferruginea), típica da vegetação de Cerrado e de Caatinga.

Para os moradores do Sítio Histórico e Patrimônio Cultural, Kalunga "é um lugar sagrado que não pode pertencer a uma só família, é um lugar que nunca seca, bom para plantar”(96). O território Kalunga se constitui em uma área localizada entre serras, morros, vãos, minas e rios, considerada uma das mais preservadas em todo o bioma do cerrado. $\mathrm{O}$ relevo é acidentado, com encostas íngremes, paredões de pedras e caminhos estreitos e tortuosos que dificultam o acesso a essas populações e das comunidades até os centros urbanos. A fauna e a flora típicas das regiões de cerrado se distinguem por exercer grande importância na manutenção das águas e dos ecossistemas brasileiros, com os buritis indicando a presença de água e as inúmeras cachoeiras que formam um cenário de rica beleza natural ${ }^{(97)}$.

A região é cercada pelas serras do Mendes, Mocambo, Mangabeira, Bom Jardim, Areia, São Pedro, Moleque, Boa Vista, Contenda, Bom Despacho, Maquiné e Ursa. Sua rede hidrográfica, bacia do Rio Paranã, afluente do Rio Tocantins, é bastante densa e caudalosa, sofrendo grandes cheias na temporada de chuvas, o que desempenha importante papel na 
deposição de material orgânico nos vales e planícies, a eles trazendo uma adubação natural, fenômeno que favorece a atividade agrícola.

As roças são a base peculiar da economia e a comunidade sobrevive na região conhecendo a natureza e utilizando essa sabedoria para produção de ferramentas, construção de moradias, garantia de alimentos e tratamento da saúde. A cultura deste povo é notoriamente marcada por um forte vínculo com o cultivo de suas terras e com o cerrado, perpassado pela ancestralidade. Os arranjos dos sistemas de produção são dependentes, principalmente, da potencialidade produtiva do meio ambiente que prove os recursos para as atividades rurais agrícolas de subsistência, pecuária tradicional, pesca, caça e artesanato.

As relações de parentesco estruturam a sociedade Kalunga. A terra, espaço do homem, é ocupada coletivamente pelo núcleo familiar (...). Os espaços são definidos obedecendo à qualidade da terra e a proximidade de água. No quintal ou terreiro cultivam as plantas frutíferas, nas várzeas inundadas pelas cheias do rio Paranã, naturalmente adubadas, nas encostas e vãos próximos às grotas e córregosas roças" ${ }^{(96)}$.

Sobre isto, Almeida ${ }^{(98)}$ explica que o território Kalunga representa substancialmente uma convivialidade caracterizada enquanto espécie de relação social, política e simbólica que liga o homem à sua terra enquanto constrói sua identidade cultural. A autora complementa inferindo que uma identidade cultural é composta por elementos que, juntos, formam um todo integrado e inter-relacionado, como a língua, a história, o território, os símbolos, as leis, os valores, as crenças e outros elementos tangíveis, incluindo a tecnologia.

A origem da comunidade Kalunga está, indubitavelmente, atrelada à própria história da colonização do Brasil e remonta a 1722, por meio do movimento migratório das Entradas e Bandeiras. Com a descoberta de ouro no século XVIII onde atualmente se localiza o Estado de Goiás, o povoamento da região Centro-Oeste foi intensificado, sendo grande parte constituída por mão-de-obra escrava responsável pelo trabalho de extração do minério. $\mathrm{O}$ censo em Goiás de 1779 ratifica o proposto ao indicar que nas cidades mineradoras algo em torno de $70 \%$ da população era constituída por "pretos": Crixá, 79,9\%; Cavalcante, 75,9\%; Carmo, 75,6\%; Pontal, 73,4\%; São Feliz, 71,5\%; Pilar, 70,8\%; Tocantins, 70,7\%; e, Arrayas, $70,4 \%{ }^{(99)}$.

No norte de Goiás, por volta da terceira década do referido século, instalaram-se as 'Mynas de Tocantins'. Assim, determinou-se o desenvolvimento da lavoura e pecuária, com a consequente prosperidade das fazendas e com a formação dos arraiais. O desbravamento desse interior e a ocupação das terras ao redor do vale do Paranã contribuíram para o 
povoamento do Estado de Goiás, uma vez que se formaram vários municípios. Em 1740 e 1769, respectivamente, tiveram origem nesta região as cidades de Cavalcante e Santo Antônio do Morro do Chapéu, hoje Monte Alegre de Goiás, ambas conhecidas por utilizarem mão-deobra escrava para a mineração.

A partir da fuga de escravos africanos das fazendas e do trabalho nas minas de ouro com refúgio entre as serras e vales, acredita-se que o quilombo dos Kalungas tenha nascido e, posteriormente, se expandido pela migração de escravos alforriados, índios e outras pessoas que adquiriram terras nas proximidades ${ }^{(96)}$.

Pode-se, assim, dizer que a Comunidade Kalunga formou-se, por ocasião do século XVIII, com mulheres e homens negros e, também, minorias indígenas e brancas cuja história se aproximava, em algum momento, da resistência ao sistema escravocrata. Refugiados em quilombos na Serra da Contenda, região do "Sertão goiano"(100), tornaram-se livres, resistindo a perseguições e ofensivas por parte dos senhores de engenho, capitães do mato e bandeirantes. Sem dúvidas, as distâncias geográficas, a topografia acidentada entre as serras para dificultar a localização e manter um sistema de vigilância próprio, a qualidade das terras nos vãos e a abundância da água dos rios - para o plantio de subsistência e a pesca - foram fatores determinantes na fixação dos negros e na formação do quilombo Kalunga.

Nesse processo, apesar de não ser possível falar em real isolamento, já que, para garantir sua autonomia, os quilombos sempre mantiveram relações com uma ampla gama de agentes externos, pode-se evidenciar que as regiões ocupadas por quilombolas mantiveram-se durante muitos anos "de certo modo isolada do poder oficial"(96), relegando a este grupo um caminho velado e silenciado pelo preconceito, discriminação, injustiça, desigualdade e iniquidade e reforçando uma situação de exclusão frente às melhores oportunidades e condições de vida.

Frente à conjuntura supramencionada, os quilombolas Kalungas desenvolveram ao longo de seu percurso histórico características próprias de organização político-social com uma identidade étnica traduzida por elementos culturais e religiosos que os distinguem na sociedade. Entretanto, a fragilidade das condições de vida dessas comunidades evidencia as consequências desta trajetória ao longo de séculos de segregação e não acesso a direitos sociais. 
Na década de 1980, as primeiras pesquisas sobre os Kalungas foram realizadas, sendo até então, informações sobre aquela população praticamente inexistentes ${ }^{(96)}$. Esta década também se destacou pela própria organização da comunidade, que começou a se mobilizar em busca dos direitos integrantes de sua cidadania ${ }^{(101)}$. O ponto de partida foi o pedido para impedir a grilagem de terras, na área considerada de remanescentes de quilombos, e, posteriormente, a regularização de sua posse, assim como o reconhecimento enquanto quilombolas contemporâneos ${ }^{(102)}$. Destaca-se que o reconhecimento e a titulação das terras ocupadas por comunidades remanescentes de quilombos têm como objetivo garantir a preservação de valores culturais e históricos relativos à contribuição do negro no processo de formação do povo brasileiro ${ }^{(103)}$.

A partir da Constituição Federal promulgada em 1988, a questão quilombola ganha destaque no cenário político nacional e as comunidades quilombolas têm, pela primeira vez, seus direitos estabelecidos no Brasil. O Ato das Disposições Constitucionais Transitórias, artigo 68 determina: "aos remanescentes das comunidades dos quilombos que estejam ocupando suas terras, é reconhecida a propriedade definitiva, devendo o Estado emitir-lhes títulos respectivos"(13). Além disso, os artigos 215 e 216 da CF/1988, que tratam do patrimônio cultural brasileiro, estabeleceram a proteção às manifestações afro-brasileiras e o tombamento de documentos e sítios detentores de "reminiscências históricas dos antigos quilombos" ${ }^{,(82)}$. Convencionou-se interpretar que o que caracteriza uma atual comunidade quilombola é sua descendência do campesinato negro constituído durante o período escravocrata $^{(104)}$.

Em 21 de janeiro de 1991, a Assembleia Legislativa do Estado de Goiás sancionou a Lei $\mathrm{n}^{\mathrm{o}}$ 11.409, que estabeleceu a região enquanto Sítio Histórico e Patrimônio Cultural Kalunga, em texto que delimita a área do sítio histórico e prevê a exclusividade da propriedade das terras aos seus habitantes, bem como a desapropriação e a titulação em favor da comunidade ${ }^{(106)}$. A normatização referida garantiu o direito à primeira titulação de terras aos Kalungas e foi subsidiada por estudos e pela construção de um mapa da região dos Kalungas feito pela equipe do Projeto Kalunga Povo da Terra da Universidade Federal de Goiás e adotado pelo extinto Instituto de Desenvolvimento Agrário de Goiás - IDAGO. Mais tarde, em 05 de janeiro de 1996, ocorreu a ratificação desse processo, que culminou com a criação do Sítio Histórico e Patrimônio Cultural Kalunga por meio de outra Lei Complementar, sob número 19/1996 ${ }^{(96)}$. 
Em 2009 o governo federal assinou 30 decretos de regularização de territórios quilombolas em 14 estados brasileiros. Inclui-se nesse ato a regularização do território dos Kalungas. Para os remanescentes, este ato busca reparar uma dívida histórica e social da sociedade brasileira em relação a este grupo étnico, se caracterizando em marco histórico no reconhecimento legal da regularização fundiária de comunidades quilombolas no País ${ }^{(107)}$.

Desta forma, refletir sobre os quilombos e sobre os quilombolas no atual contexto é, portanto, falar de uma história de conquistas políticas e sociais ainda em processo de construção, contudo longe de atingir o ideal. As populações quilombolas despertam uma série de questões socioeconômicas, jurídicas e culturais que fazem parte da discussão sobre o que representam os quilombos contemporâneos na atualidade e, principalmente, sobre quais os caminhos e estratégias para o alcance de sua efetiva inserção cidadã ${ }^{(54)}$. A inclusão destas comunidades em uma agenda de discussões político-governamentais tem como proposição norteadora contribuir para reparar "a imensa dívida do Estado brasileiro para com a população negra, que sofre a dupla opressão, enquanto camponesa e parte de um grupo racial inserido numa sociedade pluriétnica, mas desigual”(108).

A Comunidade tradicional rural Kalunga do nordeste de Goiás é considerada o mais representativo e significativo remanescente de quilombo do país, em números populacionais e território contínuo. É formada por cerca de 5.000 moradores quilombolas distribuídos numa área de 253,2 mil hectares de terra. Seus principais enfrentamentos se referem à questão fundiária, à dificuldade de acesso à saúde, à educação e aos bens materiais. Na área de saúde, em especial, verifica-se precariedade na estrutura dos serviços destinados à prestação da assistência, somada à baixa disponibilidade de insumos e equipamentos, além do reduzido número de profissionais, da desvalorização dos conhecimentos medicinais herdados pela cultura Kalunga e das grandes barreiras geográficas ${ }^{(109)}$.

Sobre os Kalungas, pode-se dizer que seus modos de pensar, vivenciar e agir refletem os traços da cultura africana e da história afro-brasileira, e se constituem na identidade viva de um povo marcado por singularidades. As casas são simples, sem portas internas, feitas de adobe, o telhado é de palha e madeira e o chão de terra batida. Não existe energia elétrica, a iluminação ocorre por meio de lamparina ou lampião. O modo de vida é rústico, utilizam fogão a lenha, as panelas são lavadas no rio, é precária a existência de banheiro sanitário e a higiene corporal é realizada nos córregos e rios. 
A condição de pobreza extrema é refletida no enfrentamento de problemas graves, como: analfabetismo, baixo índice de renda per capta, condições deficitárias de moradia, limitações de acesso e de utilização de serviços de saúde e educação e, principalmente, falta de infraestrutura e saneamento com precariedade nas condições higiênico-sanitárias, não utilização de água tratada e ausência de rede de esgoto.

No ano de 2004, foi realizado pela Fundação Universitária de Brasília - FUBRA o "Levantamento Sócio, Econômico e Cultural Quilombo Kalunga"(109). Este contou com o apoio financeiro da Secretaria Especial de Políticas de Promoção de Igualdade Racial SEPPIR e envolveu as lideranças e os membros da comunidade quilombola Kalunga. A pesquisa teve um cunho de levantamento censitário, contudo apresentou algumas limitações devido à natureza da população estudada: seu componente rural, sem sistema de endereçamento e com subnotificações quanto à documentação (registro de nascimento) dos moradores.

De acordo com os dados apresentados no referido estudo censitário ${ }^{(109)}$, pode-se dizer que a população Kalunga, à época, agrupava um total de 3.531 moradores, constituindo 958 famílias, habitando 884 domicílios em 62 povoados. Aproximadamente 58\% dos Kalungas residiam no município de Cavalcante, 25\% em Monte Alegre de Goiás e 17\% em Teresina de Goiás.

Os domicílios, de modo geral, se distribuem espaçadamente em povoados ao longo dos municípios de Cavalcante, Teresina de Goiás e Monte Alegre, sendo sua quase totalidade própria ou cedida e composta por uma única unidade familiar com um número médio de quatro moradores. Em relação ao sexo do responsável pelo domicílio, predominam os responsáveis do sexo masculino, com destaque para a baixa escolaridade destes moradores, dos quais a maioria nunca frequentou a escola.

Sobre as características populacionais, os dados apresentados pela SEPPIR/GO(109) mostram que na comunidade Kalunga há um discreto predomínio da população masculina. Levando-se em consideração os três grandes grupos etários - crianças e adolescentes ( 0 a 15 anos incompletos), idade de trabalhar (15 a 65 anos incompletos) e idosos (mais de 65 anos), conforme divisão caracterizada pela própria comunidade -, quantitativamente prevalecem os Kalungas em idade de trabalhar, seguidos pelos adolescentes e, por último, pelos idosos. A 
maioria das crianças e adolescentes sabe ler e escrever em contraposição aos idosos, que são analfabetos.

O baixo nível de escolaridade na comunidade reflete uma realidade comum no meio rural brasileiro, em que a ausência de escolas afetou principalmente as pessoas mais velhas, grupo no qual se encontra maior parte dos analfabetos ${ }^{(110)}$. As dificuldades, no que tange à questão da educação, devem-se às grandes distâncias que as crianças e jovens têm que percorrer a pé para chegar à escola, bem como ao próprio modelo de ensino oferecido nas escolas existentes, contribuindo, até mesmo, para altos índices de evasão escolar. Sobre isso, autores como Anjos e Cypriano ${ }^{(111)}$ complementam apontando que as dificuldades educacionais nas comunidades quilombolas devem-se não somente ao número de escolas, mas também ao conteúdo ministrado, que não considera as especificidades culturais da população.

Dentre a Comunidade Kalunga, a principal forma de abastecimento de água é por nascentes. Na grande parte dos casos não há canalização da água e, quando existe ligação a uma rede de água, esta ocorre em apenas em um único ponto, quase sempre fora do espaço intradomiciliar. A quase totalidade das casas não tem banheiro com chuveiro e privada e alguns domicílios dispõem de "casinha" no terreno. Nesses casos, o escoamento do esgoto ocorre por meio de vala a céu aberto ou fossa seca (buraco).

Com relação aos resíduos sólidos produzidos nos domicílios, não existe infraestrutura de coleta na região, sendo a queimada a destinação adotada por grande parte da Comunidade Kalunga. Nota-se que praticamente não existem nos domicílios bens do tipo aparelhos eletrodomésticos. As justificativas para tal realidade prendem-se ao fato da maioria dos domicílios não dispor do fornecimento de energia elétrica, bem como evidenciam certo acesso precário aos meios de comunicação de massa e à falta de exposição às inovações tecnológicas.

A economia Kalunga depende do uso de recursos naturais e apenas uma pequena parte da produção agrícola é comercializada. Os Kalungas sobrevivem do trabalho na roça, da produção de artesanatos, da criação de pequenos rebanhos e de pesca, acrescidas da renda mínima provinda de aposentadorias e de outras ajudas governamentais. A produção para subsistência é praticada por grande parte da comunidade, sendo a mandioca, o arroz, a abóbora e o milho os quatro principais itens cultivados.

São inúmeros os problemas de natureza econômico-social aos quais os Kalungas estão submetidos, e tal situação acaba por impactar na própria dinâmica populacional da 
comunidade, provocando o êxodo rural, especialmente entre os mais novos, que buscam melhores condições de vida nos grandes centros como Brasília e Goiânia ${ }^{(96)}$. Sobre os aspectos econômicos da comunidade Kalunga, Marinho ${ }^{(112)}$ complementa inferindo que a pouca disponibilidade de recursos, tanto de renda quanto de acesso a produtos do mercado e serviços, é um ponto de fragilidade dessa comunidade, impactando, inclusive, para uma condição de cidadania incompleta.

De maneira geral, os Kalungas vivem em uma condição de iniquidade social bastante comum em praticamente todas as comunidades quilombolas no Brasil ${ }^{(101)}$. As condições de moradia, os parcos recursos de acesso a bens e serviços, os problemas relacionados à falta de serviços básicos e de infraestrutura, imprimem uma condição de exposição a um danoso quadro de vulnerabilidades, inclusive em se tratando de saúde, haja vista que esta tem forte gradiente social que tende a ser desfavorável aos indivíduos pertencentes aos grupos menos favorecidos, como é o caso da comunidade quilombola Kalunga.

\subsection{OS DETERMINANTES SOCIAIS DE SAÚDE}

As diferentes definições de DSS, seja maior ou menor detalhamento, se estruturam a partir da concepção de que as condições de vida e trabalho, tanto dos indivíduos quanto de grupos ou parcelas populacionais, estão relacionados com sua situação de saúde ${ }^{(40)}$.

O principal desafio da abordagem de temas que englobam a interface determinantes sociais e saúde consiste em estabelecer uma hierarquia de determinações entre os fatores mais gerais de natureza social, econômica, política e as mediações, por meio das quais esses fatores incidem sobre a situação de saúde de grupos e pessoas, visto que a relação de determinação não é uma simples relação direta de causa-efeito ${ }^{(54)}$. Entretanto, o estudo dessa cadeia de mediações apresenta importante contribuição em se tratando da atenção à saúde, pois permite identificar onde e como devem ser feitas as intervenções, por meio do reconhecimento de pontos mais sensíveis onde tais intervenções podem provocar maior impacto com o objetivo de reduzir as iniquidades de saúde ${ }^{(40)}$.

Em termos conceituais, outro desafio se refere à distinção entre os determinantes de saúde dos indivíduos e os de grupos e populações, pois alguns fatores que são importantes para explicar as diferenças no estado de saúde dos indivíduos não explicam as diferenças entre grupos de uma sociedade ou entre sociedades diversas. Assim, os fatores individuais são 
importantes para identificar que indivíduos no interior de um grupo estão submetidos o maior risco, ao passo que as diferenças nos níveis de saúde entre grupos estão mais relacionadas com outros fatores, principalmente o grau de equidade na distribuição de renda ${ }^{(54)}$.

Nesta perspectiva $\mathrm{e}$ frente às peculiaridades das comunidades tradicionais quilombolas, destaca-se a relevância de se compreender as relações entre saúde e seus determinantes sociais, uma vez que o conceito de saúde reflete a conjuntura social, econômica, política e cultural dos grupos, não representando a mesma coisa para todas as pessoas. Os remanescentes quilombolas se singularizam por, entre outros fatores, apresentar uma trajetória histórica de invisibilidade social e exclusão ao acesso às políticas públicas, que resultou em graves desigualdades nas condições de vida e saúde ${ }^{(113)}$.

Cada comunidade, na condição de contexto socioambiental, condiciona e determina a saúde e o adoecimento, por meio das relações estabelecidas entre os indivíduos e os sistemas ambientais em que vivem, sejam estes compostos de seres vivos e não vivos ${ }^{(114)}$. Logo, é inegável que as condições de vida e trabalho dos indivíduos e de grupos da população estão relacionadas com sua situação de saúde. E os determinantes sociais são, justamente, os fatores e mecanismos pelos quais as condições sociais afetam a saúde e que potencialmente podem ser alterados por meio de ações baseadas em informação ${ }^{(115)}$.

O Brasil tem se destacado nessa abordagem, pois seria o único Estado a ter uma comissão oficial para estudos de determinantes sociais na saúde, criada em 13 de março de 2006 por meio de Decreto Presidencial. Para a Comissão Nacional, sobre os Determinantes Sociais da Saúde (CNDSS), os DSS são os fatores sociais, econômicos, culturais, étnicoraciais, psicológicos e comportamentais que influenciam a ocorrência de problemas de saúde e seus fatores de risco na população ${ }^{(54)}$.

O atual consenso acerca da influência dos DSS na situação de saúde foi sendo construído gradativamente ao longo da história. Em meados do século XIX, entre os diversos paradigmas explicativos para os problemas de saúde, predominava a teoria miasmática. Esta preconizava que a "ciência médica é intrínseca e essencialmente uma ciência social", sendo as condições econômicas e sociais responsáveis por exercer um efeito importante sobre a saúde e a doença, e que tais relações devem ser submetidas à pesquisa científica. As influências desta corrente de pensamento também podem ser verificadas no termo "saúde pública", o qual expressa o caráter político e a orientação para uma prática que implica necessariamente na 
intervenção na vida política e social, identificando e eliminando os fatores que prejudicam a saúde da população ${ }^{(116)}$.

Nas últimas décadas do século XIX, com o trabalho de bacteriologistas como Koch e Pasteur, afirma-se um novo paradigma para a explicação do processo saúde-doença: o paradigma bacteriológico. Com isso, ao longo do século XX, durante a conformação inicial da saúde pública enquanto campo científico, foi possível observar um conflito entre os enfoques biológico e social do processo saúde-doença.

A história da Organização Mundial da Saúde pode ilustrar estes momentos de tensão com períodos de forte preponderância de enfoques mais centrados em aspectos biológicos, individuais e tecnológicos, intercalados com outros em que se destacam fatores sociais e ambientais. Em 1948, a própria definição de saúde como estado de completo bem-estar físico, mental e social, e, não meramente a ausência de doença ou enfermidade, caracteriza-se em uma clara expressão ampla da saúde, para além de um enfoque centrado na doença. Entretanto, logo em seguida, durante a década de 1950, com a erradicação da varíola, têm-se uma ênfase nas campanhas de combate a doenças específicas, com o foco na aplicação de tecnologia de prevenção ou cura ${ }^{(40)}$.

No final dos anos 70, a Conferência de Alma-Ata, e as atividades inspiradas no lema "Saúde para todos no ano 2000”, recolocam em destaque o tema dos determinantes sociais. Contudo, nos anos de 1980, o predomínio do enfoque da saúde como um bem privado desloca novamente o pêndulo para uma concepção centrada na assistência médica individual, a qual, na década seguinte, anos de 1990, com o debate sobre as Metas do Milênio, novamente temse uma maior ênfase nos determinantes sociais que se afirma com a criação da Comissão sobre Determinantes Sociais da Saúde da OMS, em 2005, cujo objetivo é promover, em âmbito internacional, uma tomada de consciência sobre a importância dos DSS na situação de saúde dos indivíduos e populações e sobre a necessidade do combate às iniquidades de saúde por eles geradas ${ }^{(40)}$.

De tal maneira, nos últimos anos, observa-se um avanço no estudo das relações entre a maneira como se organiza e se desenvolve uma determinada sociedade e a situação de saúde de sua população ${ }^{(117)}$. Tal avanço é particularmente marcante no estudo das iniquidades em saúde, grupo de desigualdades de saúde entre parcelas populacionais que se caracterizam pelo 
fato de que, além de sistemáticas e relevantes, são também evitáveis, injustas e desnecessárias $^{(44)}$.

Os estudos desenvolvidos acerca das iniquidades em saúde podem ser classificados segundo três gerações. A primeira geração se dedicou a descrever as relações entre pobreza e saúde; a segunda, a traçar os gradientes de saúde de acordo com vários critérios de estratificação socioeconômica; e a terceira e atual geração está dedicada principalmente aos estudos dos mecanismos de produção das iniquidades ${ }^{(118)}$.

Por outro lado, também, podem-se salientar as diferentes abordagens para o estudo dos mecanismos por meio dos quais os DSS provocam as iniquidades de saúde. Uma delas privilegia os "aspectos físico-materiais" na produção da saúde e da doença, entendendo que as diferenças de renda influenciam a saúde pela escassez de recursos dos indivíduos e pela ausência de investimentos em infraestrutura comunitária (educação, transporte, saneamento, habitação, serviços de saúde, e outros), decorrentes de processos econômicos e de decisões políticas. Outro enfoque privilegia os "fatores psicossociais", explorando minunciosamente as relações entre percepções de desigualdades sociais, mecanismos psicobiológicos e situação de saúde, com base no conceito de que as percepções e as experiências de pessoas em sociedades desiguais provocam estresse e prejuízos à saúde. Os enfoques "ecossociais" e os chamados "enfoques multiníveis" buscam integrar as abordagens individuais e grupais, sociais e biológicas numa perspectiva dinâmica, histórica e ecológica. Existem, ainda, os enfoques que buscam analisar as relações entre a saúde das populações, as desigualdades nas condições de vida e o grau de desenvolvimento da trama de vínculos e associações entre indivíduos e $\operatorname{grupos}^{(40)}$.

Vários modelos esquemáticos procuram representar a trama de relações entre os DSS em seus diversos níveis. O modelo de Dahlgren e Whitehead, por exemplo, apresenta diferentes esferas, as quais representam os DSS dispostos de forma sobreposta em camadas $^{(119)}$. 


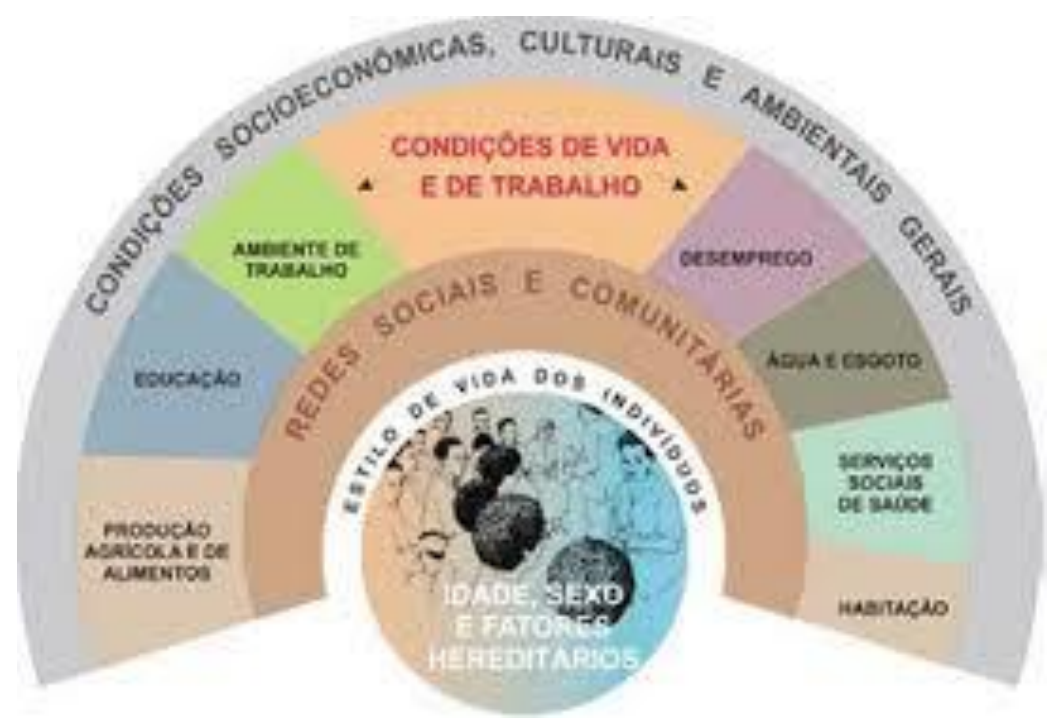

Figura 1 - Determinantes sociais: modelo de Dahlgren e Whitehead

Segundo o representado no esquema, os indivíduos estão na base do modelo, com suas características individuais de idade, sexo e fatores genéticos exercendo influência sobre seu potencial e suas condições de saúde ${ }^{(120)}$.

As camadas intermediárias perpassam pelos estilos de vida, pelas redes sociais e comunitárias e pelos fatores relacionados às condições de vida e trabalho, sendo representadas em diversas categorias de acordo com os níveis de intervenção demandados. A camada representativa do comportamento e estilos de vida individuais está situada no limiar entre os fatores individuais e os DSS, já que os comportamentos, muitas vezes entendidos apenas como de responsabilidade individual, dependentes de opções feitas pelo livre arbítrio das pessoas. De tal maneira, eles podem também ser considerados parte dos DSS, já que essas opções estão fortemente condicionadas por determinantes sociais - como informações, propaganda, pressão dos pares, possibilidades de acesso a alimentos saudáveis e espaços de lazer, dentre outros ${ }^{(40)}$.

A camada seguinte destaca a influência das redes comunitárias e de apoio, cuja maior ou menor riqueza expressa o nível de coesão social, que é de fundamental importância para a saúde da sociedade como um todo. No próximo nível estão representados os fatores relacionados a condições de vida e de trabalho, disponibilidade de alimentos e acesso a ambientes e serviços essenciais, como saúde e educação, indicando que as pessoas em desvantagem social correm um risco diferenciado, criado por condições habitacionais mais humildes, exposição a condições mais perigosas ou estressantes de trabalho e acesso menor aos serviços. As condições de vida e trabalho incluem elementos como alimentação, 
saneamento básico e acesso à informação, que, consequentemente, são influenciados pela posição social ocupada, denotando, inclusive, as vulnerabilidades aos impactos ambientais ${ }^{(40)}$.

O último nível do modelo compreende os macrodeterminantes relacionados às condições econômicas, culturais e ambientais da sociedade. Esta camada mais distal se distingue por exercer grande influência sobre os elementos que compõem as demais camadas. Assim, os macrodeterminantes se constituem em alvo de várias políticas públicas; contudo, ressalta-se que as atuações a este nível tendem a serem processos mais morosos por enfrentarem conceitos e práticas culturais que já estão arraigados na sociedade ${ }^{(120)}$.

Com relação à esquematização de Dahlgren e Whitehead, destaca-se que, apesar da facilidade da visualização gráfica dos DSS e sua distribuição em camadas, segundo seu nível de abrangência, o modelo não pretende explicar com detalhes as relações e mediações entre os diversos níveis e a gênese das iniquidades. Contudo, ilustra de maneira didática as possibilidades de intervenção sobre os determinantes sociais de saúde, uma vez que permite a identificação de pontos para intervenções de políticas públicas, visando o minimizar de diferenciais nos DSS originados pela posição social dos indivíduos e grupos ${ }^{(40)}$.

Assim, o primeiro nível, relacionado aos fatores comportamentais e de estilos de vida, indica que estes estão fortemente influenciados pelos DSS, pois é muito difícil mudar comportamentos de risco sem alterar as normas culturais que os influenciam. Isto, pois, quando se atua exclusivamente sobre os indivíduos, às vezes se consegue que alguns deles mudem de comportamento, mas logo estes serão substituídos por outros ${ }^{(121)}$. Frente ao exposto, entende-se que para atuar nesse nível de maneira eficaz, são necessárias políticas de abrangência populacional que promovam mudanças de comportamento, por meio de programas educativos, comunicação social, acesso facilitado a alimentos saudáveis, criação de espaços públicos para a prática de esportes e exercícios físicos, bem como proibição à propaganda do tabaco e do álcool em todas as suas formas ${ }^{(40)}$.

O segundo nível corresponde às comunidades e suas redes de relações. Os laços de coesão social e as relações de solidariedade e confiança entre pessoas e grupos são fundamentais para a promoção e proteção da saúde individual e coletiva. Desta forma, ressalta-se a validade da inclusão de políticas que busquem estabelecer redes de apoio e fortalecer a organização e participação das pessoas e das comunidades, especialmente dos grupos vulneráveis. Tal estratégia engloba as ações coletivas para a melhoria das condições de 
saúde e bem-estar do grupo, visando que os indivíduos se constituam em atores sociais e participantes ativos das decisões da vida social.

O terceiro nível, por sua vez, se refere à atuação das políticas sobre as condições materiais e psicossociais onde as pessoas vivem e trabalham, buscando assegurar melhor acesso a água limpa, esgoto, habitação adequada, alimentos saudáveis e nutritivos, emprego seguro e realizador, ambientes de trabalho saudáveis, serviços de saúde e de educação de qualidade e outros. Essas políticas, apesar de terem sua condução atrelada a setores distintos, precisam operar de maneira articulada por meio de mecanismos de ações integradas.

O quarto nível de atuação, por se referir à atuação ao nível dos macrodeterminantes, apresenta um largo espectro de abrangência. Deste modo, as intervenções nestes grupos de DSS ocorrem por meio de políticas macroeconômicas e de mercado de trabalho, de proteção ambiental e de promoção de uma cultura de paz e solidariedade. Elas devem visar, principalmente, a promoção do desenvolvimento sustentável, reduzindo as desigualdades sociais e econômicas, as violências, a degradação ambiental e seus efeitos sobre a sociedade $^{(122)}$.

Outro exemplo de modelo esquemático que visa representar os diversos níveis de DSS é o de Diderichsen e Hallqvist, descrito em 1998 e posteriormente adaptado por Diderichsen, Evans e Whitehead em 2001. Este enfatiza a estratificação social gerada pelo contexto social, que confere aos indivíduos posições sociais distintas, as quais provocam diferenciais de saúde ${ }^{(123)}$.

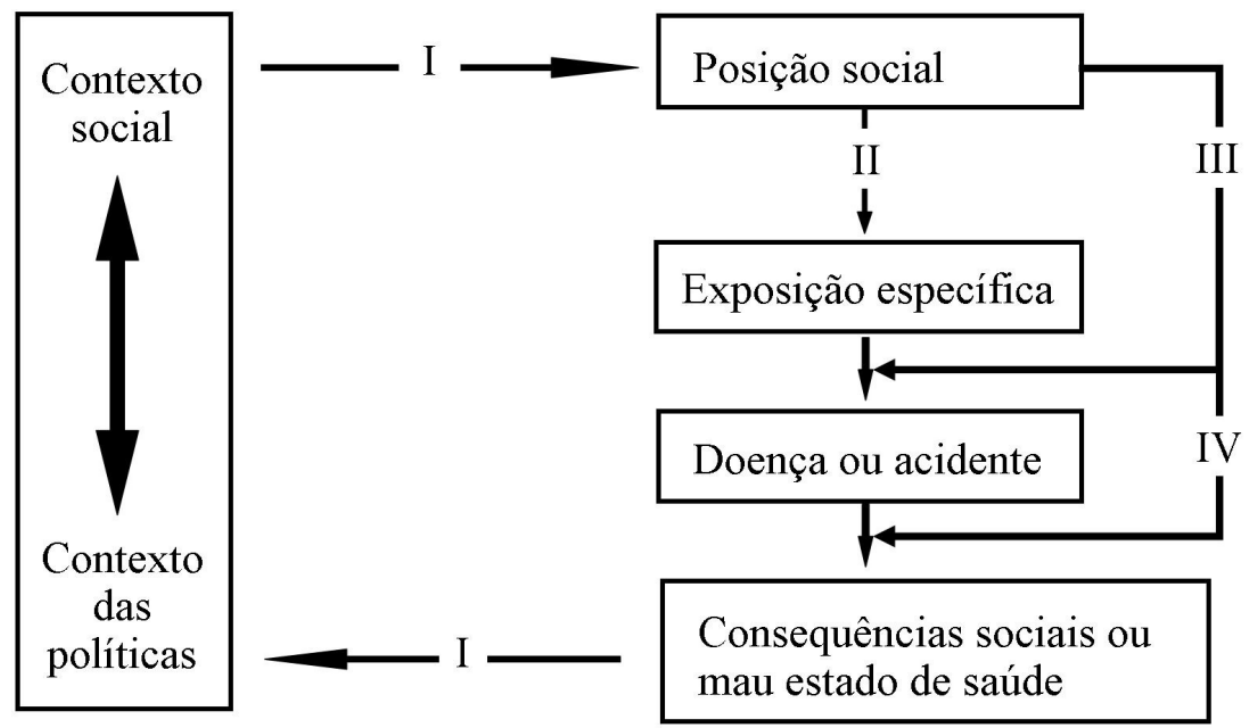

Figura 2 -Determinantes sociais: modelo de Diderichsen e Hallqvist 
No diagrama anteriormente apresentado, (I) representa o processo segundo o qual cada indivíduo ocupa determinada posição social, originado enquanto resultado de diversos mecanismos sociais, como, por exemplo, o sistema educacional e o mercado de trabalho. De acordo com o perfil social ocupado pelos diferentes indivíduos, aparecem diferenciais, como o de exposição a riscos que causam danos à saúde (II); o de vulnerabilidade à ocorrência de doença, uma vez exposto a estes riscos (III); e o de consequências sociais ou físicas, uma vez contraída a doença (IV). Por "consequências sociais" entende-se o impacto que a doença pode ter sobre a situação socioeconômica do indivíduo e sua família ${ }^{(40)}$.

O modelo em questão também possibilita que sejam identificados pontos favoráveis para as intervenções sobre os DSS. Estes pontos de incidência de políticas devem possibilitar a atuação sobre os mecanismos de estratificação social e sobre os diferenciais de exposição, de vulnerabilidade e de suas consequências. Incluindo-se políticas que diminuam as diferenças sociais, como as relacionadas ao mercado de trabalho, educação e seguridade social, além de acompanhamento de políticas econômicas e sociais para avaliar seu impacto e diminuir seus efeitos sobre a estratificação social. Por outro lado e em caráter concomitante e complementar, outro conjunto de políticas deve ser priorizado visando diminuir os diferenciais de exposição a riscos, tendo como alvo os grupos que vivem em condições de habitação insalubres, trabalham em ambientes pouco seguros ou estão expostos a deficiências nutricionais $^{(40)}$.

De um modo geral, acredita-se que todas as intervenções sobre os DSS, sejam em níveis macro, intermediário ou micro de DSS, têm como eixo condutor o diminuir das iniquidades relacionadas à estratificação social, além de obrigarem a uma atuação coordenada entre os vários setores sociais, abarcando diversos níveis da administração pública, devem estar também acompanhadas por políticas mais gerais de caráter transversal que fortaleçam a coesão e ampliação do "capital social" das comunidades vulneráveis, e promovam a participação social no desenho e implementação de políticas e programas ${ }^{(124)}$.

Portanto, sobre a importância dos determinantes sociais na situação de saúde de indivíduos e populações e sobre a necessidade do combate às iniquidades de saúde por eles geradas, é possível inferir que ao se conhecer os elementos/fatores determinantes às condições de vida e saúde dos indivíduos e da comunidade, em especial as historicamente vulneráveis, como é o caso da Comunidade Kalunga, torna-se possível proporcionar ações mais adequadas à realidade de indivíduos e grupos. Os dados, informações e conhecimentos sobre DSS podem 
contribuir com proposição de indicadores, visando proporcionar melhores condições à qualidade de vida, por meio de intervenções específicas voltadas para os DSS que representam aspectos negativos à saúde da população. Ou seja, possibilita identificar a melhor seleção, adequação e planejamento de ações em saúde a serem desenvolvidas objetivando a integralidade e a universalidade da atenção, como princípio de justiça social no contexto dos remanescentes quilombolas Kalungas.

\subsection{SAÚDE AMBIENTAL}

A relação entre o ambiente e o padrão de saúde de uma população define um campo de conhecimento referido como "saúde ambiental" ou "saúde e ambiente"(23). Existe um grande número de fatores ambientais que podem afetar a saúde humana, sendo este um indicativo da complexidade das interações existentes e da amplitude de ações necessárias para melhorar os fatores ambientais determinantes da saúde.

As preocupações com as questões ambientais estão inseridas na Saúde Pública desde seus primórdios. Entretanto, a ênfase relativa dada as diferentes subáreas dentro do campo de atuação da saúde pública tem variado ao longo da história, sobre influência do momento político e das questões de saúde mais relevantes em cada período e local. Pode-se dizer que a partir da década de 1970, com o agravamento dos problemas ambientais causados pelo crescimento industrial, as temáticas correlatas meio ambiente ganharam visibilidade de forma mais intensa e global, com ênfase na sua vinculação com a saúde humana ${ }^{(125)}$.

Na década de 1980, no Brasil, foram promovidas iniciativas para se instituir, no âmbito do setor saúde, ações de Vigilância do Meio Ambiente, de acordo com a Constituição de 1988 e a Lei Orgânica de Saúde de 1990. Mas é a partir do ano 2000 que o Ministério da Saúde formulou a denominada Vigilância Ambiental, hoje Vigilância em Saúde Ambiental $^{(126)}$. Assim, a saúde ambiental antes relacionada quase que exclusivamente ao saneamento e qualidade da água, incorporou outras questões que envolvem poluição química, pobreza, equidade, condições psicossociais e a relevância de um desenvolvimento sustentável para as gerações atuais e futuras.

A concepção em questão se apoia no conceito de saúde a partir de sua perspectiva ampliada, a qual leva em consideração as dimensões biológicas, sociais, psíquicas e ecológicas, articulando assim o individual com o coletivo no contexto do processo saúde- 
doença, determinado e condicionado por fatores históricos, genéticos e estruturais de origem biopsíquicos, sociais e ecológicos/ambientais ${ }^{(23)}$.

A promulgação da Constituição Federal de 1988 se constituiu em importante marco no processo de aproximação entre as questões inerentes ao meio ambiente, incluindo as situações de risco ambientais, e a saúde de indivíduos, grupos e populações. O Artigo de número 225 do texto constitucional remete à estreita relação entre meio ambiente e saúde enquanto qualidade de vida ao dispor que "todos têm o direito ao meio ambiente ecologicamente equilibrado, bem de uso comum do povo e essencial à sadia qualidade de vida, impondo-se ao Poder Público e à coletividade o dever de defendê-lo, preservá-lo para as presentes e futuras gerações"(13).

Assim, juntamente com a evolução da legislação, ampliou-se a consciência de que a saúde, em suas dimensões física e mental, está intrinsecamente relacionada à qualidade do meio ambiente. Essa relação tem se tornado cada vez mais evidente para a sociedade devido à significativa redução da qualidade ambiental ${ }^{(23)}$. Atualmente, o meio ambiente se constitui em um dos temas essenciais da agenda governamental e uma das grandes preocupações dos cidadãos e demandando uma consciência político-social, seja nos países industrializados ou não.

Ao longo das últimas décadas, os avanços tecnológicos, o processo de globalização e as mudanças estruturais nas relações econômicas resultaram em novas formas de produção e ocupação territorial. Realidade que, por sua vez, culminou na consolidação de novos hábitos pela população, criando padrões diferenciados de consumo e de interação com o ambiente. Esse modelo de desenvolvimento, sob o qual estamos vivendo, condiciona as relações sociais, culturais e econômicas, acentuando, assim, os riscos para a saúde e gerando problemas para o ambiente $^{(25)}$. Ademais, uma das consequências desse modelo de desenvolvimento adotado foi a intensa degradação ambiental que se testemunha no planeta, evidenciada no aquecimento gradual do globo terrestre, no efeito estufa, na poluição dos oceanos, na poluição do ar, solo e água, na redução da camada de ozônio, na possibilidade de acidentes nucleares, entre outros.

Destaca-se que as situações às quais se atribui o conceito de problemas ambientais têm um amplo espectro de elementos impactantes, apresentando em um de seus extremos os problemas pontuais, circunscritos e localizados; e, em outro, as situações que envolvem desafios como as condições de deterioração do meio físico e da qualidade de vida de extensas 
regiões e populações ${ }^{(25)}$. Essa degradação, seja em nível micro ou macro, tem consequências diretas sobre a qualidade de vida e as condições de saúde da coletividade.

Por exemplo, as alterações dos ecossistemas terrestres e aquáticos, que podem acarretar agravos à saúde devido a mudanças de condições específicas; aumento da incidência e/ou prevalência de câncer de pele está associado à destruição da camada de ozônio pelo uso do clorofluorocarbono; as mudanças da temperatura no planeta apresentam influência na dispersão de contaminantes, além da reemergência de certas doenças infecciosas causadas pela interferência ambiental na presença de vetores, sua virulência e patogenicidade.

Na população brasileira, à semelhança do que acontece em outras regiões espalhadas pelo globo terrestre, há o reflexo das situações exemplificadas anteriormente. Este se traduz na coexistência de doenças infectocontagiosas e crônico-degenerativas, ambas vinculadas, em algum nível, aos fatores ambientais. As primeiras, de modo mais direto, relacionadas à presença de vetores e à contaminação das águas, e as crônico-degenerativas, fundamentalmente, à poluição ambiental, à má qualidade dos alimentos e ao estresse ${ }^{(125)}$.

Segundo a Organização Mundial da Saúde, a relação pessoa humana-meio ambiente incorpora todos os elementos e fatores que potencialmente afetam a saúde, incluindo, entre outros, desde a exposição a fatores específicos como substâncias químicas, elementos biológicos ou situações que interferem no estado psíquico do indivíduo, até aqueles relacionados a aspectos negativos do desenvolvimento social e econômico dos países ${ }^{(60)}$.

Dessa forma, estabelecer as interfaces entre as condições ambientais e a saúde da população é uma área de conhecimento que a cada dia ganha mais importância. Assim, faz-se premente o olhar atentivo para as relações que o homem estabelece com o meio ambiente, já que este repercute na própria condição de existência de vida, em todas as suas formas. O saber ambiental é uma alternativa à crise acarretada pela degradação meio, configura-se no reconhecimento da complexidade que envolve as relações entre sociedade e ambiente ${ }^{(127)}$. Em sua base de conhecimentos, a saúde ambiental emerge com o intuito de subsidiar a promoção de mudanças ambientais relacionadas à saúde enquanto qualidade de vida.

A Secretaria de Vigilância em Saúde, na Instrução Normativa n. ${ }^{\circ} 01 / 2005^{(128)}$, define que a saúde ambiental compreende a área da saúde pública que aproxima o conhecimento científico e a formulação de políticas públicas relacionadas à interação entre a saúde humana e os fatores do meio ambiente natural e antropogênico que a determinam, condicionam e 
influenciam, com vistas a melhorar a qualidade de vida do ser humano, sob o ponto de vista da sustentabilidade.

O reconhecimento dos contextos socioambientais e culturais, em que os problemas envolvendo a relação homem-ambiente são conformados, pode contribuir para que ocorram as necessárias mudanças na busca ou manutenção de espaços saudáveis, transformando os impactos negativos ao ambiente em prol da qualidade de vida e saúde das populações. As relações de interdependência entre saúde, desenvolvimento econômico, qualidade de vida e meio ambiente vem sendo reconhecidas, de um modo geral, na comunidade científica, e empregadas no direcionamento de políticas públicas de saúde em diferentes países, visto que expressam o nível de equilíbrio das redes de conexão entre sociedades humanas e natureza $^{(128)}$.

Essa dimensão da saúde ambiental a caracteriza enquanto componente que atravessa diversos campos disciplinares, envolvendo a atuação de profissionais de diversas formações acadêmicas e técnicas, tanto das áreas biológicas, quanto das ciências da natureza, das ciências exatas e incluindo todos os profissionais da área das ciências da saúde. A saúde ambiental atual volta-se para a atenuação das disparidades regionais em termos de salubridade do ambiente, reconhecendo a existência e as necessidades de todos os seres humanos. Também se baseia no encontro de soluções dentro dos princípios de equidade e universalidade $^{(125)}$, sendo fundamental para fortalecer o conceito mais amplo de Saúde cunhado na Reforma Sanitária Brasileira, viabilizando-o, de fato, enquanto direito inalienável garantido pela nossa Constituição Federal.

\subsection{INFRAESTRUTURA, SANEAMENTO E SAÚDE}

A Lei Federal n. ${ }^{\circ} 11.445$, de 2007, dispõe sobre as diretrizes nacionais para o saneamento básico. Segundo este texto constitucional, saneamento básico é definido como um conjunto de serviços, infraestrutura e instalações operacionais de abastecimento de água potável, esgotamento sanitário, limpeza urbana e manejo de resíduos sólidos e drenagem e manejo das águas pluviais urbanas, destinados às populações a partir de princípios como integralidade, equidade, universalidade, planejamento, intersetorialidade e controle social ${ }^{(129)}$.

Frente ao exposto, verifica-se a impossibilidade das reflexões em saúde pública sem a consideração de elementos relativos à questão do saneamento básico. Saneamento e saúde são 
áreas que se tangenciam, em um movimento dinâmico ora de causa, ora de consequência, o que torna inviável refletir sobre essas temáticas de forma isolada e cartesiana. Mesmo concernidas de práticas e saberes, com identidade própria, necessitam de intersetorização. Tal aproximação remonta à própria definição dos vocábulos: saúde e saneamento.

Segundo a $\mathrm{OMS}^{(26)}$, saneamento é o controle de todos os fatores do meio físico do homem, que exercem ou podem exercer efeitos nocivos sobre o bem-estar físico, mental e social, compreendendo as medidas que visam preservar ou modificar as condições do meio ambiente com a finalidade de prevenir doenças e promover a saúde. De outra forma, pode-se dizer que saneamento caracteriza o conjunto de ações socioeconômicas que tem por objetivo alcançar certo nível de salubridade ambiental compatível com a qualidade de vida e a saúde dos habitantes de determinada região.

Heller $^{(50)}$ corrobora com o fato de que o conceito de saneamento admite amplas interpretações sobre as ações abrangidas e disciplinas envolvidas, inferindo que, para efeito de padronização, a tendência predominante no Brasil tem sido a de considerar como integrantes do saneamento as ações de: abastecimento de água, caracterizando como o fornecimento às populações de água em quantidade suficiente e com qualidade que a enquadre nos padrões de potabilidade; esgotamento sanitário, compreendendo a coleta dos esgotos gerados pelas populações e sua disposição de forma compatível com a capacidade do meio ambiente em assimilá-los; limpeza pública, incluindo todas as fases de manejo dos resíduos sólidos domésticos, até sua disposição final, compatível com as potencialidades ambientais; drenagem pluvial, significando a condução das águas pluviais, de forma a minimizar seus efeitos deletérios sazonais sobre as populações e as propriedades; controle de vetores de doenças transmissíveis, especialmente artrópodes e roedores.

Já a saúde, segundo a mesma organização ${ }^{(26)}$ em sua definição clássica, é apresentada como um estado de completo bem-estar físico, mental e social, e não somente a ausência de doenças. Isso mostra que estes dois sistemas estão diretamente relacionados, sendo de suma importância considerar as questões ambientais no entendimento do comportamento de saúde de uma determinada população.

Os indicadores sanitário-ambientais têm sido considerados como instrumentos valiosos na análise de informações sobre saúde e ambiente, colaborando para a execução de ações de controle de fatores ambientais que possam influenciar na ocorrência de doenças e 
agravos em populações humanas. Estes se caracterizam em medidas-síntese que contêm informações relevantes sobre determinados atributos do ambiente. Tais indicadores refletem a situação sanitária de uma população, constituindo-se em recurso fundamental para a vigilância das condições tanto do ambiente como da saúde ${ }^{(130)}$.

A complexidade da sociedade contemporânea culminou em uma maior abrangência da ação antrópica sobre o ambiente, o que, desse modo, como em uma reação em cascata, demandou também a expansão da visão dos determinantes ambientais sobre a saúde. Outras questões relevantes foram chamadas para compor o leque de problemas ambientais e o risco à saúde a ele associados: a poluição atmosférica, o emprego de agrotóxicos na agricultura, o estresse urbano e a radiação ${ }^{(50)}$.

A relação saneamento-saúde-ambiente começa a ser envolvida por um movimento de ampliação, no qual percepções tradicionais são revisitadas por novas ideias, fundamentandose em novos paradigmas. Há uma tendência de ampliação do conceito reducionista de saneamento alicerçado na prevenção de doenças e definido enquanto intervenção de engenharia no espaço físico, voltada para a saúde com o objetivo de obstaculizar a transmissão de agravos, assegurando a salubridade do ambiente ${ }^{(131)}$. Buscam-se caminhos para uma abordagem intersetorial, pautada na convergência de interesses e na realização de ações conjuntas voltadas para o saneamento alicerçado na promoção da saúde. O saneamento como promoção da saúde se ocupa da intervenção multidimensional no ambiente, considerado em suas dimensões física, social, econômica, política e cultural, visando à saúde - entendida como qualidade de vida; erradicação da doença pelo combate integral às suas causas e determinantes -, por meio da implantação ações integradas dos diversos setores governamentais e da sociedade civil $^{(132)}$.

O conceito de saneamento sob a ótica da promoção da saúde o coloca como ação positiva para a saúde, compartilhando com este setor, e com os demais setores ligados aos determinantes da saúde, a responsabilidade de erradicar as doenças, ou pelo menos eliminálas de forma duradoura, a partir de mudanças na situação dos indivíduos e de seu ambiente por meio dos sistemas de engenharia, tendo como preocupação essencial não apenas a implantação desses sistemas, mas principalmente seu funcionamento pleno, duradouro e acessível a toda a população ${ }^{(133)}$. 
O saneamento é peça fundamental para o desenvolvimento social e econômico de uma comunidade, interferindo diretamente na qualidade de vida dos indivíduos, haja vista sua implicação essencial para a conquista de uma boa saúde. Entretanto, o que se observa é que, em proporções crescentes, as atividades humanas, respaldadas no avanço e no desenvolvimento, têm determinado alterações significativas no meio ambiente, influenciando tanto na disponibilidade de uma série de recursos naturais quanto na distinção das áreas de coberturas pelos serviços de infraestrutura básica. A água, em alguns territórios, tem se tornado um recurso escasso e com qualidade comprometida. Os crescentes desmatamentos, os processos de erosão/assoreamento dos mananciais superficiais, os lançamentos de efluentes e detritos industriais e domésticos nos recursos hídricos têm contribuído para tal situação.

Nos países em desenvolvimento, essa problemática é agravada em razão da baixa cobertura da população com serviços básicos de saneamento, como abastecimento de água com qualidade e quantidade, coleta e tratamento dos esgotos. O sistema de abastecimento de água e esgotamento sanitário inadequado é responsável pela maioria das enfermidades incluídas nas denominações "feco-oral, transmissão hídrica ou relacionada com a higiene", denominada como a categoria "A" da classificação ambiental das doenças infecciosas, apresentando, como fonte comum de contaminação, as fezes humanas em água, em alimentos, nas mãos e, frequentemente, em utensílios domésticos e no ambiente peridomiciliar ${ }^{(134)}$.

Em nosso Estado, a rede de serviços básicos de saneamento vem se expandindo, porém observa-se que esse crescimento tem sido insuficiente para suprir as necessidades de toda a população, resultando em iniquidades, em especial, em se tratando de comunidades rurais, de pequeno porte e afastadas dos centros urbanos. Dados do Instituto Brasileiro de Geografia e Estatística - IBGE ${ }^{(135)}$ mostram que mais de 40 milhões de pessoas não têm acesso à rede de água e que 100 milhões não têm serviços de esgoto em suas residências, o que leva a um agravamento no quadro higiênico-sanitário do Brasil.

Verifica-se, ainda, que as populações vulneráveis socialmente são as mais prejudicadas em termos de não acesso aos serviços de abastecimento de água, sendo ainda pior a situação da cobertura por serviços de esgotamento sanitário ${ }^{(136)}$. Philippi ${ }^{(137)}$ corrobora com o proposto ao citar o Manual de Saneamento da Fundação Nacional de Saúde FUNASA, acrescentando que, mais comumente, são os brasileiros mais pobres que têm seus direitos sociais negados e sofrem as consequências da insipiência de algumas políticas 
públicas que não garantem o atendimento de suas necessidades com relação ao saneamento básico.

Deste modo, faz-se relevante evidenciar que esses grupos populacionais menos favorecidos economicamente, em especial os residentes em áreas rurais, são duplamente afetados pelas questões correlatas a falta de saneamento. Isso ocorre porque, além da desigualdade quanto ao acesso a bens e serviços de infraestrutura básica, os riscos decorrentes da insalubridade do meio afetam com maior intensidade as populações mais pobres. A população mais vulnerável corresponde justamente àquela excluída dos benefícios do desenvolvimento. Em outras palavras, a persistência da problemática do saneamento encontra-se fortemente associada ao modelo socioeconômico praticado nos países não desenvolvidos, dentre eles o Brasil, indicando assim a ineficácia dos "sistemas" existentes.

A priorização de investimentos em ações de saneamento básico reflete diretamente nas condições ambientais e, consequentemente, no bem-estar humano, produzindo a redução na morbidade e estando diretamente relacionadas com a saúde da população. O proposto, além de contribuir fundamentalmente para as ações de saúde pública e de proteção ambiental, não deixa de ser também um bem de consumo coletivo, um serviço essencial e um direito do cidadão e um dever do Estado ${ }^{(138)}$.

O Brasil só poderá ser considerado um país com um grau mais elevado de desenvolvimento, quando, sua população apresentar menores carências na cobertura de atendimento dos serviços de saneamento. Assim, será rompido o paradigma da atuação pontual e fragmentada, passando a vigorar políticas públicas que preconizem ações voltadas à melhoria dos serviços já prestados e à implementação de novos, na perspectiva de gerar melhores condições de vida às populações e ambientes saudáveis por meio de abastecimento d'água, instalação de fossas, melhoria habitacional, destino e tratamento adequado dos excretas, identificação e eliminação dos locais propícios para a procriação de insetos vetores. De fato, a saúde é um direito de cada cidadão em cada comunidade do território brasileiro.

\subsection{DOENÇAS DE VEICULAÇÃO HÍDRICA}

A água potável é a água própria para o consumo humano, e, para ser assim considerada, deve atender aos padrões de potabilidade. Se ela contém substâncias que desrespeitam estes padrões, ela é considerada imprópria para o consumo humano. As 
substâncias que indicam esta poluição por matéria orgânica são compostos nitrogenados, oxigênio consumido e cloretos. O propósito primário para a exigência de qualidade na água de consumo humano é a proteção à saúde pública.

Os critérios adotados para assegurar essa qualidade se propõem a fornecer uma base para o desenvolvimento de ações que, se propriamente implementadas junto à população, garantirão a segurança do fornecimento de água por meio da eliminação ou redução às concentrações mínimas de constituintes na água conhecidos por oferecerem riscos à saúde ${ }^{(139)}$.

A Organização Mundial da Saúde destaca o papel fundamental do monitoramento da água consumida pelos grupos populacionais e justifica tal proposição com base nos altos índices de morbimortalidade referentes a enfermidades veiculadas pela água, incluindo as diarreias. Em outras palavras, as doenças de veiculação hídrica estão atreladas à possibilidade da água, direta ou indiretamente, ser também responsável por transmitir doenças. E, são causadas principalmente por microrganismos patogênicos de origem entérica, seja animal ou humana, transmitidos basicamente pela rota fecal-oral, que se caracteriza pela excreção dos agentes causadores nas fezes de indivíduos infectados, seguida pela ingestão na forma de água ou alimento contaminado por água poluída com fezes ${ }^{(140)}$.

Os principais agentes biológicos identificados nas águas contaminadas são as bactérias patogênicas, como a salmonella; os vírus, como o rotavírus; e, os parasitas como a Giardia lamblia. Pode-se referir que as bactérias patogênicas encontradas na água e/ou alimentos constituem uma das principais fontes de morbidades em nosso meio. São as responsáveis pelos numerosos casos de enterites, diarreias infantis e doenças epidêmicas, com resultados frequentemente letais. Os vírus mais comumente encontrados nas águas contaminadas por dejetos de animais de sangue quente, incluindo o homem, são os da poliomielite e da hepatite infecciosa. Dentre os parasitas que podem ser ingeridos por meio da água, destaca-se a Entamoeba hystolytica, causadora da amebíase e suas complicações, incluindo as com comprometimento hepático ${ }^{(139)}$.

Dentre as diversas doenças veiculadas pela água e considerando as taxas de frequência, Rouquayrol ${ }^{(141)}$ destaca a poliomielite, hepatite $\mathrm{A}$, febre tifoide, cólera, salmonelose, shigelose, amebíase e a esquistossomose. Tais agravos à saúde, juntamente com as condições de habitação e saneamento, surgem como importantes indicadores para a avaliação das vulnerabilidades socioambientais das populações. 
A água está presente no cotidiano de qualquer indivíduo, seja para o preparo de alimentos, para ingestão objetivando hidratação, higiene e asseio corporal, limpeza de utensílios domésticos e da moradia, banho e descarga de vasos sanitários, dentre outros usos importantes. Dessa forma, a condição de não disponibilidade de água potável em quantidade adequada, bem como as falhas na proteção das fontes de captação ou abastecimento, podem expor as comunidades a riscos de agravos em saúde, e também comprometer a qualidade de vida. Segundo a OMS, grande parte de todas as doenças que se alastram nos países em desenvolvimento são provenientes da água de má qualidade ${ }^{(142)}$.

De acordo com os autores Cairncross e Feachem ${ }^{(143)}$ e Heller ${ }^{(144)}$, as doenças relacionadas à água podem ser agrupadas segundo uma classificação ambiental, na qual se evidenciam quatro grandes subtipos. Os critérios de subdivisão dos grupos são constituídos a partir da importância da água de forma direta ou indireta na transmissão/prevenção dos agravos. Assim, a classificação ambiental das infecções relacionadas à água, seja em quantidade ou em qualidade, origina-se a partir do entendimento sobre o modo de transmissão da doença e sua interface com a água:

1) Agravos transmitidos pela água - Neste primeiro grupo estão reunidas as doenças cujo agente etiológico tem origem na contaminação fecal ou por esgotos das fontes de água, as quais evidenciam a falta de saneamento básico. Exemplos: gastroenterites, hepatite A, cólera, febre tifoide, entre outras;

2) Agravos vinculados à falta de higiene - No segundo grupo, encontram-se doenças que seriam facilmente evitadas se a comunidade tivesse maior quantidade de água de boa qualidade, educação sanitária e bons hábitos higiênicos. Exemplos: impetigo, escabiose, pediculose, entre outras;

3) Agravos vinculados ao contato com a água - No terceiro grupo, encontram-se as doenças caracterizadas pela penetração do agente etiológico através da pele e não pela ingestão da água contaminada. A transmissão baseada no ciclo de vida do inseto na água, uma vez que o agente patogênico desenvolve parte do seu ciclo vital em um animal aquático. Exemplo: esquistossomose, em que o hospedeiro do ovo é um caramujo;

4) Agravos cuja transmissão ocorre por um inseto vetor que procria na água e suas picaduras ocorrem nas proximidades da água - Este quarto grupo de doenças de veiculação hídrica caracteriza-se pela existência de condições favoráveis à proliferação dos vetores de 
habitat aquático. Exemplo: dengue, febre amarela, malária, entre outros.

Segundo dados apresentados no Manual de Saneamento da FUNASA ${ }^{(145)}$, em todo o mundo um bilhão de pessoas não possuem acesso à água potável e cerca de 1,7 bilhões de pessoas convivem com estruturas de saneamento inadequadas. Como resultado dessas condições precárias de saneamento e acesso à água de qualidade, mais de três milhões de pessoas, a cada ano, morrem de doenças de veiculação hídrica. No Brasil, essa realidade não é diferente. Mais de $90 \%$ dos esgotos domésticos e cerca de $70 \%$ dos efluentes industriais são lançados diretamente em corpos de água, sem qualquer tipo de tratamento.

Em regiões carentes e excluídas da rede básica de serviços públicos, como os bolsões de pobreza das favelas e as regiões afastadas dos centros urbanos, a falta de acesso a fontes seguras de água é fator agravante das condições precárias de vida. Por exemplo, nas áreas rurais, onde sabidamente a adequação da captação e uso da água é mais negligenciada, o risco de ocorrência de doenças de veiculação hídrica é mais alto quando comparado às cidades. Isto se dá, principalmente, em função das inúmeras possibilidades de contaminação dos poços rasos e nascentes comumente utilizados pelos moradores das áreas rurais, fontes bastante susceptíveis a contaminação, por fossas e áreas de pastagem ocupadas por animais ${ }^{(146)}$.

Destaca-se ainda a significativa contribuição, durante o período das chuvas, das águas de escoamento superficial na mudança da qualidade microbiológica da água em consequência do arraste de excretas humanas e animais. A necessidade de buscar fontes alternativas, contribui, também, para que a população seja impelida ao consumo de água com qualidade sanitária duvidosa, em volume insuficiente e irregular para o atendimento das necessidades básicas diárias. Soma-se a isto a questão do uso de vasilhames não apropriados para o acondicionamento desses recursos, condições inadequadas de transporte e armazenamento da água até o seu consumo, bem como, o comprometimento das práticas de higiene pessoal, doméstica e dos alimentos relacionadas à escassez e as dificuldades de acesso a água ${ }^{(147)}$.

O abastecimento de água de qualidade e em quantidade suficiente tem importância fundamental para promover condições higiênicas adequadas, proteger a saúde da população e promover o desenvolvimento socioeconômico. Dessa forma, tendo como ferramenta os indicadores construídos a partir da avaliação epidemiológica das doenças de veiculação hídrica, sua classificação e distribuição ambiental, deve-se priorizar a adoção de medidas 
segundo as características específicas da região de incidência, visando o controle destes agravos.

No cumprimento legítimo de seu papel protetor, cabe ao Estado ocupar-se do reconhecimento das situações de desigualdade frente ao acesso a água de qualidade, buscando, por meio da implementação de programas guiados por políticas públicas resolutivas, minimizar os consequentes impactos da inobservância do direito universal à água potável, incluindo, entre estes, a proliferação das doenças de veiculação hídrica. O que se objetiva, assim, é proporcionar melhores condições de vida e saúde para as comunidades, tanto nas cidades quanto no campo, por meio de ações que impreterivelmente contemplem um ambiente fundamentalmente saudável.

\subsection{SOBRE AS PARASITOSES INTESTINAIS}

A saúde das populações se define enquanto resultado das formas de organização social e de produção, as quais podem gerar grandes desigualdades nos níveis de vida. Esta rede complexa de fatores se inter-relaciona e condiciona o processo saúde-doença na especificidade do indivíduo e na abrangência do modo de vida coletivo ${ }^{(148)}$, uma vez que as condições de saúde dos indivíduos, grupos ou coletividade refletem seus padrões de comportamentos. Ilustrando o proposto, podem-se citar agravos como as helmintoses e protozooses, que se destacam por ocasionar altos índices de morbidade em países onde o crescimento populacional não é acompanhado da melhoria nas condições de vida ${ }^{(149)}$.

Os parasitas intestinais estão entre os patógenos mais frequentemente encontrados em seres humanos, atingindo cerca de um quarto da população mundial. São apontados como uma das mais relevantes causas de agravo à saúde e, embora apresentem baixas taxas de mortalidade, constituem-se em significativo problema de saúde pública, haja vista o grande número de indivíduos afetados e as várias alterações orgânicas que podem provocar decorrentes de sua ação patogênica ${ }^{(150)}$.

Em contraste com os avanços tecnológicos e científicos do mundo contemporâneo, nossa sociedade ainda abriga um grande número de doenças parasitárias, principalmente entre as camadas populacionais mais carentes ${ }^{(151)}$. A explicação para tal realidade prende-se ao fato da taxa de prevalência dos agravos enteroparasitários apresentar estreita relação com as 
condições ambientais em que o indivíduo vive, principalmente no que diz respeito aos aspectos alimentares, de abastecimento de água e destinação do esgoto e do lixo.

A ausência ou insuficiência nas condições mínimas de saneamento básico e inadequadas práticas de higiene pessoal e doméstica são os principais mecanismos de transmissão dos parasitas intestinais. Durante seu ciclo de vida, o endoparasita se hospeda em um indivíduo buscando benefícios que garantam sua sobrevivência. Esta associação desarmônica interfere diretamente na absorção de nutrientes, bem como pode acarretar quadros clínicos variáveis, os quais se encontram, frequentemente, associados à diarreia crônica e à desnutrição ${ }^{(152)}$.

Três fatores, a clássica tríade epidemiológica das doenças parasitárias, são indispensáveis para que ocorra a doença parasitária: as condições do hospedeiro, o parasito e o meio ambiente. Em relação ao hospedeiro, os fatores predisponentes incluem: idade, estado nutricional, fatores genéticos, culturais, comportamentais e profissionais. Pesa para o lado do parasito: a resistência ao sistema imune do hospedeiro e os mecanismos de escape vinculados às transformações bioquímicas e imunológicas verificadas ao longo do ciclo de cada parasito $^{(153,154)}$.

Estima-se que nos países em desenvolvimento, onde as condições de saneamento e de educação sanitária se mostram deficientes, aproximadamente, um terço da população viva em condições ambientais que facilitam a disseminação de infestações parasitárias ${ }^{(155)}$. A susceptibilidade às enteroparasitoses é capaz de variar, dentre outros fatores, com a própria condição econômica da população. Ademais, o ambiente quente dos países tropicais associado à desnutrição, falta de assistência médica, contaminação de alimentos e água, condições sanitárias precárias, presença de reservatórios e vetores, inadequadas práticas de higiene pessoal e doméstica são fatores que promovem o desenvolvimento e a propagação das formas infectantes de helmintos e de protozoários intestinais ${ }^{(156,157)}$.

Assim, tanto em decorrência dos efeitos deletérios à saúde dos indivíduos, quanto por suas repercussões econômicas, cada vez mais as infestações por helmintos e enteroprotozoários vêm demandando atenção por parte da sociedade e governantes. Várias iniciativas e programas têm sido dirigidos para o controle das parasitoses intestinais em diferentes países; contudo, muito falta para uma real efetividade. É possível se constatar 
descompasso entre o êxito alcançado nos países mais desenvolvidos e aqueles pertencentes às economias mais pobres ${ }^{(158)}$.

No Brasil, essas doenças ocorrem nas diversas regiões do país, seja em zona rural ou urbana, e em diferentes faixas etárias, com variação tanto na frequência de parasitismo intestinal entre os diferentes grupos populacionais como nos agentes responsáveis, podendo a taxa de prevalência alcançar índices de quase $80 \%$ em algumas comunidades ${ }^{(159)}$. A ampla diversidade das características socioeconômicas, climáticas e geográficas, aliada às ainda insipientes políticas públicas nesta área, acabam por contribuir como fator crítico para o perfil dos agentes etiológicos na diarreia, modelando assim a maior gravidade na frequência de enteropatógenos nas regiões com menor Índice de Desenvolvimento Humano - IDH ${ }^{(160)}$.

A comunidade quilombola Kalunga pode ser citada como exemplo de parcelas da população, onde é notória a exposição a fatores de risco oriundos da carência de serviços básicos e infraestrutura. Nessa comunidade, as consequências históricas do processo de escravidão e a forma de sua libertação têm influenciado o acesso diferenciado a bens e serviços, incluindo saúde. Assim, os Kalungas enfrentam problemas relacionados às condições de moradia, baixo nível educacional, precariedade, ou até mesmo total ausência de serviços de saneamento básico e/ou distribuição de água potável ${ }^{(36)}$, que podem estar associados à situação de risco para a ocorrência de enteroparasitoses.

Frente ao panorama apresentado, a especificidade deste grupo populacional, bem como, a própria situação de vulnerabilidade social vivenciada por estes, destaca-se a importância de estudos nesta área do conhecimento. A questão das infestações parasitárias demanda suma atenção em se tratando de saúde e qualidade de vida, isto, pois, a frequência das endoparasitoses aumenta à medida que piora o nível socioeconômico. Além disto, evidencia-se o fato de que no Brasil são insuficientes as referências sobre este tema, apesar de sua relevância na epidemiologia e saúde pública ${ }^{(161)}$.

\subsection{SOBRE O METAL PESADO MERCÚRIO}

O conhecimento das características de uma comunidade, sua dinâmica interna e as relações estabelecidas entre saúde, ambiente e condições de vida podem ser citados como importante aliado ao se refletir sobre as possibilidades de atuação, tanto de enfermeiros quanto dos demais profissionais da equipe multiprofissional, com vistas à diminuição de 
eventuais agravos, vez que a saúde pública tem forte componente horizontal, reconhecendo as particularidades de cada população e adequando-se a elas ${ }^{(35)}$.

Sabe-se que a contaminação ambiental, em especial do solo e recursos hídricos, é fruto do uso de produtos e das atividades e ações humanas no ambiente e se manifestam, principalmente, por meio de microrganismos patogênicos, como já discutido anteriormente, e de metais pesados ${ }^{(162)}$. Este último, caracteriza-se em preocupante tipo de poluição dos sistemas aquáticos e terrestres, que resulta do despejo de metais pesados e acarreta alterações no ciclo geoquímico desses elementos, concorrendo para sua maior dispersão no meio ${ }^{(163)}$.

Os metais pesados são elementos químicos que possuem peso específico maior que 5 $\mathrm{g} / \mathrm{cm}^{3}$ ou número atômico maior do que 20. Entretanto, convencionou-se a utilização do termo "metais pesados" para a tipificação de elementos químicos que contaminam o meio ambiente, provocando diferentes danos à biota ${ }^{(164)}$. Os principais elementos químicos contaminantes enquadrados neste conceito são: o arsênico, causador de problemas nos sistemas respiratório, cardiovascular e nervoso; o chumbo, capaz de atingir o sistema nervoso, a medula óssea e os rins; o cádmio, causador de problemas gastrointestinais e respiratórios; o cromo, responsável por provocar irritação na pele e, em doses elevadas, câncer; o manganês, causador de problemas respiratórios e efeitos neurotóxicos; e o mercúrio, capaz de contaminar o homem seja pela exposição ocupacional seja pela via alimentar, neste último caso sofrendo o processo de biomagnificação ao longo da cadeia trófica. Do ponto de vista toxicológico, o mercúrio é considerado o metal pesado mais nocivo ${ }^{(163)}$.

No Brasil, de modo geral, desde os anos 1980, o mercúrio é utilizado no processo de extração de ouro ${ }^{(165)}$, sendo as atividades desenvolvidas em garimpos, citadas como um fator antropogênico responsável pelo aumento, no meio ambiente, da carga total de mercúrio $(\mathrm{Hg})$, que se destaca, entre os vários metais pesados, por ser associado à contaminação do ambiente aquático devido a sua alta toxicidade ${ }^{(166)}$. Em consequência disto, o garimpo apresenta-se como um assunto polêmico e tem sido alvo de preocupação na área ambiental e da saúde pública. A temática abrange uma diversidade de questões sociais, políticas, econômicas e problemas ambientais relacionados com a utilização do mercúrio no processo de extração do ouro e na emissão de metal pesado para o ambiente ${ }^{(167)}$.

Acrescenta-se a este contexto o histórico de aproximação dos Kalungas com as atividades de garimpagem, uma vez que estas comunidades se caracterizam enquanto grupo 
de remanescentes de quilombos que se instalaram no interior dos municípios de Monte Alegre de Goiás, Cavalcante e Teresina de Goiás, oriundos do trabalho escravo existente nas minas de ouro da região do sertão do Estado de Goiás, no período da colonização do Brasil, por volta do Século XVIII. Passados mais de três séculos, mesmo que em menor proporção e/ou de maneira não oficial, ainda é possível identificar a forte presença da atividade garimpeira entre estes moradores, em especial às margens do rio Paranã, no povoado do Riachão, no município de Monte Alegre de Goiás.

O mercúrio é considerado um metal tóxico extensamente estudado em todo mundo, com distribuição no ambiente por fontes naturais ou antropogênicas e capaz de fornecer risco às populações por acarretar efeitos nocivos ao ecossistema e à saúde humana ${ }^{(168)}$. No homem, a partir do evento exposição, o mercúrio, que é um elemento traço natural, pode se concentrar em diversas partes do corpo, como pele, cabelo, glândulas sudoríparas e salivares, tireoide, sistema digestivo, pulmões, pâncreas, fígado, rins, aparelho reprodutivo e cérebro, provocando diversos problemas de saúde, entre estes os graves efeitos neurotóxicos.

Como resultados de emissões antrópicas, cita-se o processo de extração e amalgamação do minério do ouro, no qual grande parte do mercúrio empregado é depositada nos sedimentos bênticos. A partir daí, por uma série de reações químicas, o mercúrio inorgânico é transformado em metilmercúrio, composto orgânico altamente tóxico. Este, por sua vez, é bioacumulado, atingindo concentrações maiores ao longo da cadeia alimentar aquática e chegando até o homem por meio da dieta alimentar, principalmente pela ingestão de pescados, considerados como uma importante fonte de exposição ambiental do ser humano ao metal pesado ${ }^{(168)}$.

$\mathrm{O} \mathrm{Hg}$ nos peixes está principalmente na forma de $\mathrm{MeHg}$, sendo estes animais considerados importantes biomarcadores utilizados por diferentes organizações e pesquisadores com o objetivo de avaliar os níveis de contaminação de determinada biota aquática, em especial na checagem da qualidade dos pescados disponíveis para a população ${ }^{(169)}$. A importância do monitoramento dos níveis de $\mathrm{Hg}$ em frutos do mar e derivados está associada à avaliação de eventuais riscos toxicológicos para as populações.

Na mineração aluvial, com o objetivo de formar a amálgama com o ouro, o mercúrio $(\mathrm{Hg})$ é lançado nos rios, onde os íons mercuroso $\left(\mathrm{Hg}_{2}{ }^{+2}\right)$ e mercúrico $\left(\mathrm{Hg}^{+2}\right)$ podem dar origem a compostos orgânicos e inorgânicos ${ }^{(170)}$. Com relação ao $\mathrm{Hg}$ inorgânico, este pode ser 
biometilado pela ação de microrganismos presentes nos corpos d’água associados aos sedimentos de fundo, material particulado em suspensão, plâncton ou raízes da vegetação submersa $^{(171)}$. As propriedades físico-químicas das espécies mercuriais inorgânicas estão intimamente relacionadas ao ânion ao qual o metal se liga ${ }^{(172)}$, sendo a metilação do mercúrio inorgânico passo chave na ciclagem do $\mathrm{Hg}$ nos ecossistemas aquáticos ${ }^{(173)}$. Neste processo, dentre os diferentes compostos orgânicos formados, o metilmercúrio $(\mathrm{MeHg})$ é o mais comum e o mais importante, considerado, por grande parte dos estudiosos, como sendo a principal forma do $\mathrm{Hg}$ bioacumulada ao longo da cadeia alimentar ${ }^{(174)}$.

Em outras palavras, o mercúrio despejado no meio ambiente sedimenta-se no fundo das águas e se transforma em outro composto mais tóxico, o metilmercúrio, pela ação de bactérias processadoras de sulfato $\left(\mathrm{SO}_{4}\right)$, que podem liberar o composto na água, contaminando o plâncton, ou podem ainda ser consumidas por peixes, que pescados e futuramente consumidos, contaminam a espécie humana ${ }^{(175)}$. O peixe tanto absorve o metilmercúrio diretamente da água como pela ingestão de outros organismos aquáticos ${ }^{(176)}$. De modo que, mesmo em regiões com níveis normais de mercúrio na água, podem ser observados níveis altos em peixes, pois, ao ser incorporado na cadeia trófica, o mercúrio é biomagnificado e bioacumulado ${ }^{(167)}$.

O processo de bioacumulação ocorre pela transferência do metilmercúrio acumulado no primeiro nível trófico (produtores) para os consumidores, sendo que, quanto mais longa a cadeia trófica, maior a concentração acumulada pelo consumidor. Os peixes são, assim, concentradores naturais de mercúrio, sendo as espécies carnívoras as que mais contribuem para o acúmulo de $\mathrm{MeHg}$, chegando a acumular nove vezes mais que outras espécies ${ }^{(174)}$. A idade, peso e tamanho também podem influenciar no acúmulo do metal pesado no tecido muscular estriado esquelético destes animais aquáticos ${ }^{(165)}$. A permanência do peixe em águas com a presença do mercúrio enquanto poluente, principalmente em sua forma orgânica, reflete a maior exposição destes animais ao metal, acarretando, consequentemente, maior possibilidade de acúmulo gradativo ao longo da vida do animal.

O homem pode ser citado como representante dos altos níveis da cadeia alimentar, sendo mais exposto, pela dieta, a este metal pesado cuja absorção intestinal em sua forma metilada é maior que 95\%. O MeHg, devido a sua alta capacidade de incorporação pelas células, é absorvido rapidamente; contudo, é eliminado lentamente se comparado às outras 
formas mercuriais ${ }^{(177)}$. Esta baixa velocidade de eliminação relaciona-se ao fato de sua meia vida ser longa, cerca de 70 dias $^{(170)}$.

Nas intoxicações humanas, o mercúrio age como inibidor e modificador das atividades proteicas, mesmo em baixas concentrações, devido a sua afinidade com grupos sulfidrilas presentes em proteínas e sistemas enzimáticos de diferentes tecidos e órgãos ${ }^{(172)}$. O composto se acumula nos rins, no fígado e no sistema nervoso central (SNC), e a sintomatologia da contaminação se apresenta de modo inversamente proporcional ao nível de exposição ${ }^{(178)}$, sendo suas manifestações crônicas ou agudas. Por ser lipossolúvel e atravessar facilmente as membranas celulares, o metilmercúrio também tem efeito feto-tóxico, transpondo a barreira placentária e acarretando alterações irreversíveis para o feto, mesmo sem o aparecimento de sintomas na mãe ${ }^{(165)}$.

Destaca-se, assim, que a presença do mercúrio no meio pode acarretar comprometimento da biota de áreas direta ou indiretamente afetadas pela atividade garimpeira. Por isso, em se tratando da prevenção de potenciais riscos ambientais e em saúde, é de suma importância o conhecimento e o monitoramento das concentrações deste metal altamente tóxico, tanto em humanos quanto na vida aquática em particular ${ }^{(179,180)}$. 


\section{CAPÍTULO 3}




\section{QUESTÃO NORTEADORA}

Diante das considerações acerca do reconhecimento dos direitos das Comunidades Kalungas, a geografia destaca-se enquanto um dos fatores dificultadores do acesso à assistência à saúde e aos bens de consumo. Dessa forma, para guiar o presente estudo, foi proposta a seguinte questão: Tendo como pano de fundo a avaliação das condições sanitárias da Comunidade Kalunga, como podem ser descritas as condições relativas à qualidade da água destinada ao consumo humano, dos alimentos ingeridos como peixes, e ainda, outros fatores capazes de interferir na situação de saúde dos moradores, incluindo possíveis infestações parasitárias intestinais, suas espécies causadoras e magnitude? 


\section{CAPÍTULO 4}




\section{OBJETIVOS DO ESTUDO}

\subsection{OBJETIVO GERAL}

- Avaliar as condições sanitárias da população Kalunga dos municípios de Cavalcante, Teresina de Goiás e Monte Alegre, Estado de Goiás, em 2012.

\subsection{OBJETIVOS ESPECÍFICOS}

- Caracterizar o perfil socioeconômico-demográfico e epidemiológico (idade, ocupação, grau de escolaridade, estado civil, renda familiar, número de filhos) de moradores Kalunga;

- Conhecer o ambiente e as condições de saúde de moradores Kalungas nos aspectos de doenças prevalentes, moradia, transporte, abastecimento e qualidade da água, prevalência de parasitoses intestinais, magnitude de contaminação por mercúrio em moradores e em peixes, destinação de resíduos e dejetos humanos. 


\section{CAPíTULO 5}




\section{MATERIAIS E MÉTODOS}

\subsection{TIPO DE ESTUDO}

O estudo delineado é do tipo quantitativo com abordagem epidemiológica do tipo transversal-analítica ${ }^{(181)}$. Os estudos quantitativos buscam descrever significados que são considerados como inerentes a atos, viabilizando, por meio de uma abordagem objetiva, o traçar de uma cadeia de raciocínio em conexão e descendente, que leva a uma conclusão definitiva a partir de dados que são coletados por meio de respostas estruturadas e de técnicas de análise dedutivas ${ }^{(182)}$. Neste contexto, o delineamento transversal possibilita que a observação das variáveis de interesse seja feita simultaneamente, em um mesmo momento e no tempo suficiente para os dados serem coletados, demonstrando naquele momento como as variáveis analisadas estão relacionadas. E, por fim, o caráter analítico refere-se ao seu pressuposto conceitual metodológico de obtenção de conhecimentos sobre um tema, com base na investigação de associações entre eventos, no intuito de estabelecer explicações sobre as relações observadas entre eles ${ }^{(181)}$.

$\mathrm{Na}$ modalidade de investigação transversal analítica, as "causas" e "efeitos" são detectados simultaneamente. Tão somente na análise dos dados é que são identificados os grupos de interesse, "os expostos" e os "não expostos", evidenciando-se, assim, o componente de adequação ao objetivo da pesquisa em tela que se propõe a avaliar as condições sanitárias e epidemiológicas de moradores da comunidade Kalunga.

\subsection{DESCRIÇÃO DA ÁREA DE ESTUDO}

A pesquisa foi realizada na porção nordeste do Estado de Goiás, nos municípios de

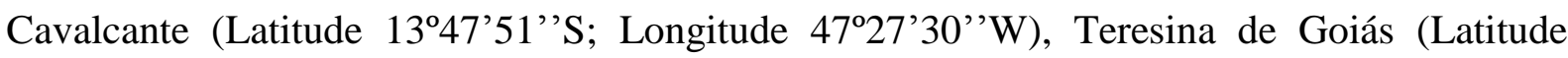

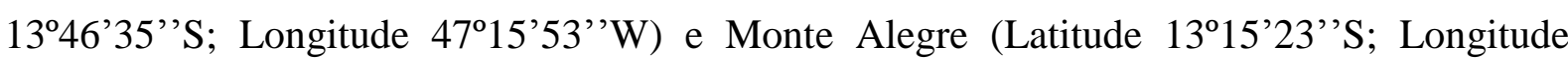
$\left.46^{\circ} 54^{\prime} 02^{\prime \prime} \mathrm{W}\right)$, na microrregião da Chapada dos Veadeiros ${ }^{(183)}$.

A região de escolha para a realização da pesquisa compreende o território identificado como Sítio Histórico e Patrimônio Cultural Kalunga, que se caracteriza por abrigar diferentes comunidades de quilombolas Kalungas e por ser o remanescente de quilombo mais importante histórico e numericamente da região Centro-Oeste ${ }^{(111,184)}$. 

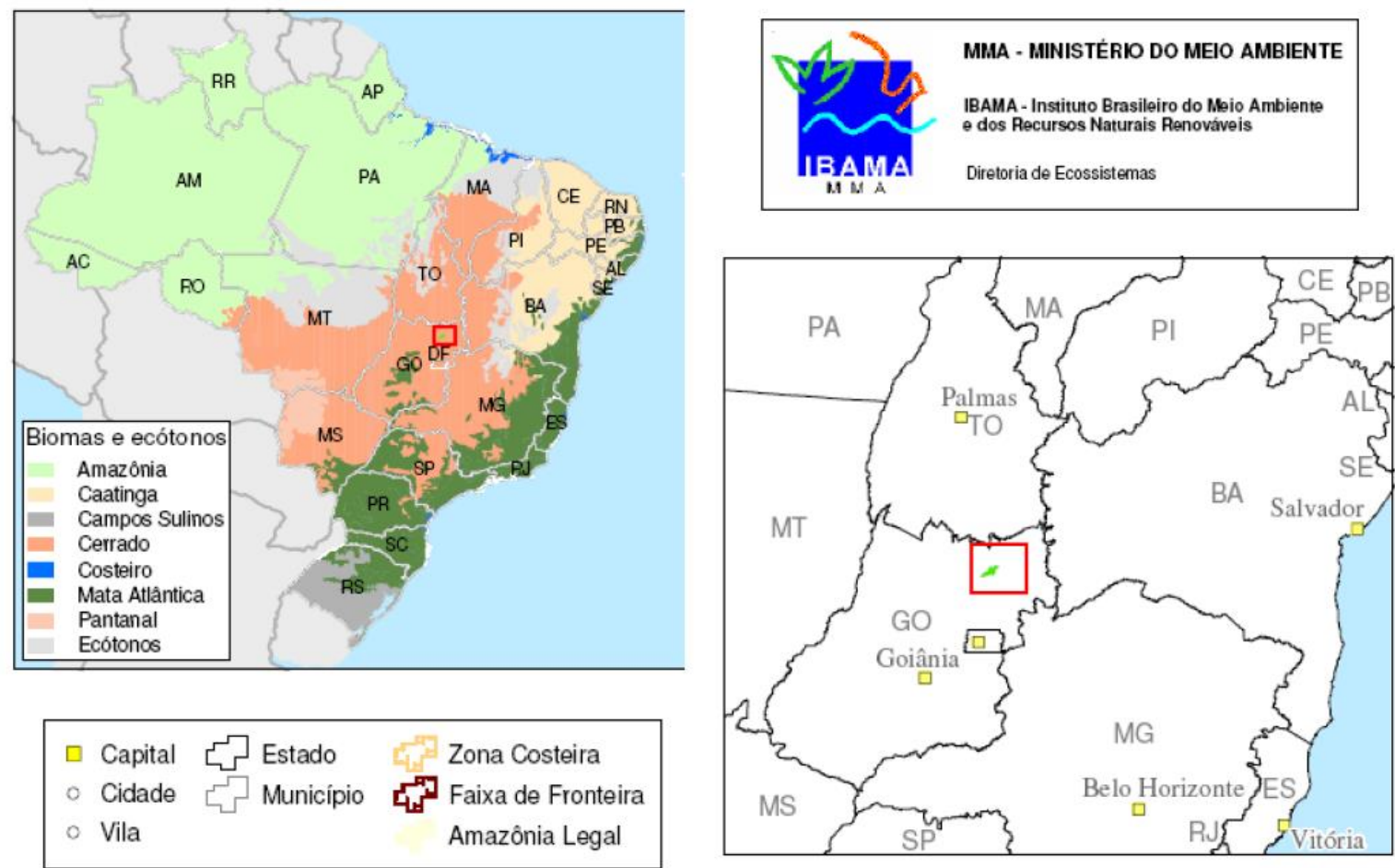

Figura 3 - Localização espacial do Sítio Histórico Cultural dos Kalungas

Crédito de autoria: Ministério do Meio Ambiente

O sítio histórico ocupa uma área de 253,2 mil hectares. Está localizado a uma distância de 600 km e 330 km das áreas metropolitanas de Goiânia e Brasília, respectivamente, bem como é considerado um espaço geográfico singular frente às demais paisagens do Estado de Goiás, onde predomina o relevo do tipo chapadões. Neste tipo de relevo tabular se identifica a presença de formações rochosas com mais de 600 metros, com a existência de uma porção plana na parte superior e cuja altitude se destaca das áreas ao redor.

A região do sítio histórico Kalunga é conhecida como Vãos da Serra Geral que, por sua vez, são ocupados pelo vale do Rio Paranã e seus afluentes e contam com presença de serras e morros, depressões e vales estreitos, rios encaixados e uma vegetação de cerrado, cerradão ou campos cerrado $^{(107)}$.

Pode-se afirmar que o território Kalunga está inserido em uma das maiores áreas contínuas de cerrado brasileiro, em especial, quando somado ao Parque da Chapada dos Veadeiros (65.514 hectares), à Área de Proteção Ambiental de Pouso Alto (872.000 hectares) e às Reservas Particulares de Patrimônio Natural - RPPN. Esse bioma é rico em biodiversidade e a segunda maior formação vegetal do país, superada apenas pela Floresta Amazônica $^{(185)}$. 


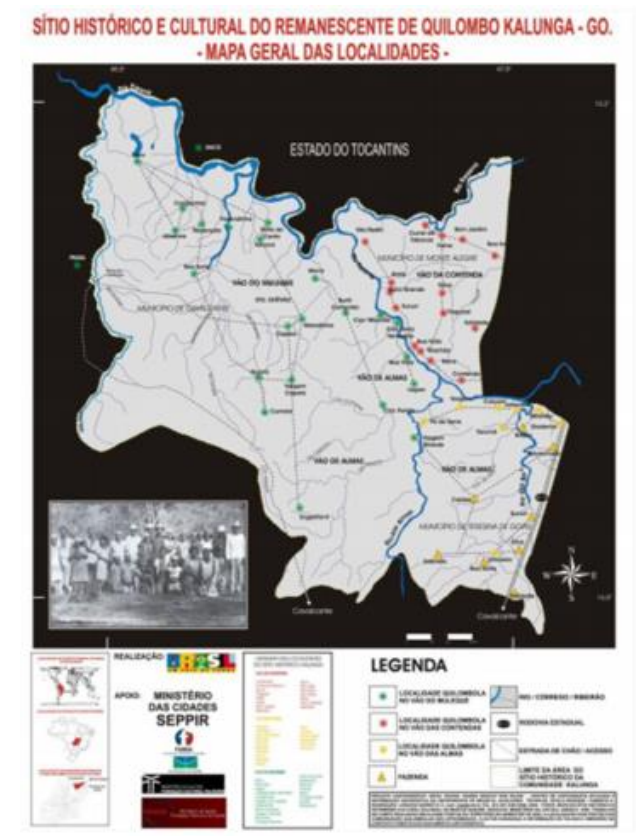

Figura 4 - Sítio Histórico Cultural dos Kalungas - Mapa Geral de Localidades Crédito de autoria: Carlos Cristovão, 2009

De maneira geral, o território do Sítio Histórico e Patrimônio Cultural Kalunga pode ser dividido em quatro núcleos principais: Ribeirão dos Bois, o antigo Ribeirão dos Negros, separado do Vão das Almas pela Serra do Funil; Vão do Moleque e Vão das Almas, ambos na margem esquerda do Rio Paranã e divididos pelas Serras do Forno e São Pedro; e, por fim, situado entre a Serra da Contenda e a Barra do Bezerra na margem direita do Rio Paranã, o Vão da Contenda Kalunga, ou ainda, mais recentemente também referenciado como Engenho II. Este é considerado o povoado de acesso mais fácil, com maior infraestrutura e de localização mais próxima aos centros urbanos de Cavalcante, Alto Paraíso e Teresina de Goiás.

Acrescenta-se que existem outros povoados distribuídos entre esses principais núcleos populacionais, como Curriola, Ema, Ribeirão, Taboca, Areia, Maiadinha, Capela ${ }^{(186)}$. Ao todo são mais de 30 comunidades Kalungas com uma população total de cerca de 5.000 indivíduos remanescentes de quilombos e distribuídos na zona rural dos municípios de Cavalcante, Teresina de Goiás e Monte Alegre ${ }^{(187)}$.

Sobre o município de Cavalcante, pode-se inferir que sua primeira formação data de 1736, quando, em busca das minas de ouro, o garimpeiro Julião Cavalcante deu início ao povoado, que mais tarde foi fundado oficialmente, mantendo o nome em sua homenagem. $\mathrm{O}$ censo demográfico de 2010 informa uma população total de 9.392 habitantes, sendo composta por uma parcela urbana de 4.742 pessoas e uma parcela rural de 4.650 pessoas $^{(188)}$. 
Teresina de Goiás foi criada como um loteamento no entorno de Cavalcante a partir da iniciativa de três homens, sejam eles, Delfino Szeerquins, José da Costa e Joaquim de Souza Fagundes. A vila formada foi elevada a distrito de Cavalcante em 1968 e à categoria de município somente 20 anos depois, em 1988. A população residente é de 3.016 pessoas, sendo 2.134 em área urbana e 882 em área rural ${ }^{(189)}$.

Já a origem da colonização do município de Monte Alegre de Goiás, anteriormente chamado Arraial do Morro do Chapéu, emergiu pela atração das pessoas na busca pelo ouro e cresceu com os esforços do trabalho escravo nas minas de ouro. Apresenta uma população de 7.730 pessoas, sendo 3.164 pessoas residentes em área urbana e 4.566 em área rural ${ }^{(190)}$.

O recorte espacial para a delimitação da área de estudo deu-se pelo fato de que a inquietação para a realização de tal pesquisa ter se originado da parceria estabelecida com as comunidades Kalungas desses municípios e, principalmente, pela aproximação prévia em que foram identificadas demandas a partir da figura dos líderes comunitários.

\subsection{OPERACIONALIZAÇÃO DO ESTUDO}

O desenvolvimento do estudo ocorreu em consequência da parceria já estabelecida entre a Comunidade Kalunga dos Municípios de Cavalcante, Teresina de Goiás e Monte Alegre e grupo de estudos coordenados pelo Professor Doutor Pedro Sadi Monteiro, com vistas à promoção de saúde deste grupo populacional.

Com relação ao desdobramento específico desse trabalho, pode-se afirmar que o contato inicial ocorreu por meio de visita ao Sítio Histórico e Patrimônio Cultural Kalunga, ocorrida no mês de maio de 2012. Esta teve como objetivo informar sobre o interesse em realizar estudo na comunidade e apresentar os objetivos da pesquisa.

Tal apresentação ocorreu em reunião previamente agendada junto às lideranças comunitárias dos três municípios. $\mathrm{Na}$ oportunidade, foi realizada a proposição do desenvolvimento do estudo, apresentação de seus objetivos, exposição da dinâmica da etapa de campo com as ações junto aos moradores e esclarecimento acerca das contribuições para a comunidade. Também foi realizada visitação de alguns povoados das comunidades com a presença do líder comunitário local, possibilitando a apresentação da pesquisadora à comunidade. 
Acredita-se que a relevância dessa etapa tenha como base o caráter de validação e ratificação da concordância na realização do estudo junto aos quilombolas Kalunga. Isto porque, anteriormente à proposição do trabalho, já havia sido demonstrada certa preocupação dos líderes comunitários locais com as questões sanitárias e de saúde na comunidade, evidenciando que a demanda pela execução da pesquisa emergiu da própria comunidade.

Em atenção ao rigor metodológico inerente aos trabalhos científicos, na oportunidade foi concedida a autorização para a execução da pesquisa por meio da assinatura do termo formal de concordância. Tal documento de aceite em relação ao desenvolvimento do estudo foi conferido pelo presidente da Associação de Moradores Quilombo Kalunga, órgão de representação legal dos moradores de toda a comunidade (Anexo 1).

Após a finalização deste trâmite de autorização, foram iniciadas especificamente as visitas para a coleta de dados de acordo com planejamento prévio. Destaca-se que o cronograma preliminar de visitações, com a especificação de datas, regiões a serem percorridas e identificação do guia Kalunga, responsável pelo acompanhamento da equipe nas visitações às famílias, foi elaborado em parceria com os líderes comunitários dos três municípios. Contudo, este planejamento inicial precisou ser remodelado, ajustado e complementado de acordo com o as informações provenientes das oficinas de trabalho e das entrevistas com os líderes comunitários, primeira etapa da coleta de dados da pesquisa em tela.

O segundo encontro com os líderes comunitários se caracterizou pela realização das entrevistas semiestruturadas individuais e pelo agendamento e estruturação dos grupos de trabalho com cada um dos grupos de moradores representante dos três município que compõem o Sítio Histórico e Patrimônio Cultural Kalunga. Neste momento foi sugerida pelos líderes a inclusão dos Agentes Comunitários de Saúde como parceiros no processo de organização dos encontros com a comunidade para a realização das oficinas. Também, por esta ocasião, foi identificada a validade de inclusão de novo elemento - teores de mercúrio na investigação sobre as condições ambientais e de saúde da comunidade Kalunga. Durante a realização das entrevistas com os líderes comunitários, emergiram referências sobre a presença de garimpo na região Kalunga e sua citação enquanto possível fator de risco à saúde dos moradores quilombolas. 
Assim, em parceria com os líderes comunitários e com os Agentes Comunitários de Saúde, foram organizadas e desenvolvidas as oficinas de trabalho sobre a temática promoção de saúde. Durante a realização das oficinas, foram reforçadas as orientações quanto à natureza e objetivos do estudo e adotados os procedimentos éticos cabíveis ao desenvolvimento de pesquisas com seres humanos.

As oficinas de trabalho se configuraram em relevante momento para a definição do subgrupo populacional característico da amostra representativa a participar da segunda etapa da atividade de coleta de dados, ou seja, receber as visitas domiciliares. Coube aos participantes das oficinas de trabalho a viabilização de informações que foram compiladas, analisadas e, posteriormente, utilizadas na delimitação das microrregiões com áreas de maior frequência na identificação dos eventuais riscos e principais problemas de saúde para a composição do grupo de moradores que participaram da etapa de visitas domiciliares.

As visitas aos domicílios visaram o preenchimento do questionário estruturado, a avaliação qualitativa dos resíduos sólidos e a coleta de materiais para as análises laboratoriais: fezes, cabelo humano, peixes e água de consumo. Todas as casas foram visitadas com o acompanhamento de guias Kalunga da localidade. Estes tiveram um papel relevante na aproximação entre os pesquisadores e os membros da família residente nos locais das visitações.

De um modo geral, a etapa de coleta de dados teve início em setembro de 2012, apresentando duração de quatro meses. Foram realizadas nove visitas de campo com permanência entre dois e quatro dias na localidade, e uma com permanência de dezesseis dias consecutivos entre os meses de setembro e outubro de 2012.

Durante todo esse processo de atividade em campo foi preconizada a comodidade e disponibilidade dos moradores. Também foi priorizado o respeito às rotinas, hábitos e costumes do grupo. A observância de tais premissas vai ao encontro dos objetivos norteadores do trabalho, ao viabilizar que a coleta dos dados, por ocorrer no interior da comunidade e por atentar para as especificidades Kalunga, reflita, com a maior semelhança possível, as condições de vida dessa população, em especial no que tange à correlação ambientesaneamento-saúde. 


\subsection{AMOSTRA}

Um importante passo no delineamento de uma pesquisa consiste na seleção dos elementos da população de interesse capazes de, efetiva e fidedignamente, fornecer dados que reflitam e caracterizem tal população, sendo a inferência estatística a ferramenta utilizada para generalizar, de maneira segura, as conclusões obtidas da amostra para a população ${ }^{(191)}$.

A Comunidade Kalunga dos municípios de Cavalcante, Teresina de Goiás e Monte Alegre caracterizou o universo desse estudo. A obtenção de dados foi realizada a partir de levantamento amostral não probabilístico por acessibilidade ou conveniência. Assim, a seleção dos elementos da população voltada para a composição da amostra dependeu, principalmente, do julgamento dos pesquisadores, de acordo com suas experiências e com os objetivos do estudo, e, ainda, considerando-se os integrantes da comunidade mais disponíveis ${ }^{(192)}$.

Para o delineamento metodológico da presente pesquisa, não houve obtenção de conceitos estatísticos prévios e os elementos da amostra foram selecionados conforme critério dos pesquisadores, tendo como base a percepção de que os elementos selecionados pudessem com sua participação agregar ao estudo. Marconi e Lakatos ${ }^{(193)}$ corroboram com o proposto e complementam inferindo que essa técnica de amostragem não enfatiza a "chance" ou probabilidade de selecionar os elementos amostrais, e sim, a acessibilidade e a rapidez na obtenção dos resultados.

De tal maneira, em consonâncias com os critérios de inclusão e exclusão do estudo, compuseram a amostra do estudo os líderes comunitários que participaram das entrevistas individuais, os quilombolas Kalungas que participaram das oficinas de trabalho realizadas em cada um dos três municípios, e os moradores que receberam as visitas domiciliares, de acordo com as microrregiões especificadas enquanto produto das oficinas de trabalho.

\subsection{TÉCNICA DE SELEÇÃO DOS PARTICIPANTES}

Como critério de participação no estudo, determinou-se a inclusão de líderes comunitários e quilombolas pertencentes à Comunidade Kalunga que residissem nos municípios de Cavalcante, Teresina de Goiás e Monte Alegre, região noroeste do Estado de Goiás. Depois de orientados sobre as características e objetivos do estudo, os moradores foram convidados a participar da pesquisa de modo voluntário. Àqueles que concordaram 
com a participação foi solicitado o consentimento formal, uma vez que a inclusão no estudo, também, esteve atrelada à assinatura prévia do Termo de Consentimento Livre e Esclarecido TCLE (Apêndice A).

\subsection{FONTE DE COLETA DE DADOS}

Os dados foram coletados, para posterior tratamento e análise, com a utilização de recursos específicos. Em um primeiro momento, estabeleceu-se como fontes de obtenção de dados primários o preenchimento de questionários estruturados, a realização de entrevistas semiestruturadas, de oficinas de trabalho e de observação direta, bem como, as análises laboratoriais de amostras da água para consumo e de fezes humanas.

Contudo, por demanda da própria comunidade, a partir das primeiras entrevistas com os líderes comunitários, incluiu-se a análise laboratorial de material específico para investigação da possibilidade de contaminação ambiental por metal pesado do tipo mercúrio. Foi citada a presença, na região do Sítio Histórico e Patrimônio Cultural Kalunga, de garimpo não regulamentado como fator de possível influência sobre as condições de vida da comunidade, em especial, em se tratando de eventuais problemas em saúde dos quilombolas.

Assim, também, foram coletados peixes oriundos de rios da região, visando à identificação dos níveis de mercúrio presente no tecido muscular de espécies consumidas pelos quilombolas Kalungas. Ainda coletaram-se amostras de cabelo de moradores, com vista à avaliação da exposição destes ao metilmercúrio. Isto porque essa substância é acumulada no cabelo e sua concentração é diretamente proporcional à concentração simultânea no sangue. Quando incorporado dentro da fibra do cabelo, a concentração do MeHg permanece estável, de modo que o cabelo serve como registro histórico de níveis sanguíneos passados ${ }^{(194)}$. Tal fato atribui ao cabelo característica de bom biomarcador, bem como evidencia sua adequação aos objetivos do estudo.

As entrevistas tiveram como instrumento um roteiro semiestruturado com questões abertas e fechadas (Apêndice B). Foram realizadas individualmente com os líderes comunitários dos três municípios, e coletivamente por ocasião da realização de oficinas de trabalho junto à comunidade. Isso porque, no entender de Poli e Hungler ${ }^{(195)}$, ninguém melhor do que as próprias pessoas envolvidas, para falar sobre o contexto que vivem. 
A opção por este recurso enquanto fonte de coleta de dados se deu, porque esse tipo de entrevista pode fazer emergir informações de forma mais livre e as respostas não estão condicionadas a uma padronização de alternativas ${ }^{(193)}$. Tal prerrogativa foi de suma importância nesta etapa inicial da coleta de dados, uma vez que se vislumbrava maior aproximação com variabilidade das questões referentes às condições sócio-sanitáriasambientais da população Kalunga.

Nesta primeira etapa da coleta de dados, também foram realizadas oficinas de trabalho, uma em cada um dos três municípios que compõem o Sítio Histórico e Patrimônio Cultural Kalunga e com os moradores da localidade. Como instrumentos norteadores da atividade, utilizou-se roteiro semiestruturado empregado nas entrevistas individuais com os líderes comunitários. Isto porque esse tipo de técnica de coleta de dados propicia ao pesquisador certa flexibilidade na captação de nuances de variabilidade e especificidades nas descrições realizadas pelos participantes ${ }^{(193)}$, o que é de grande valia quando de modo coletivo se abordam questões tão multifacetadas quanto às correlatas à tríade homem-ambiente-saúde.

Desse modo, os momentos de discussão coletiva das oficinas de trabalho possibilitaram o abordar de temas que, na percepção da comunidade, podiam ser considerados problemas persistentes, bem como oportunizou o ratificar de informações convergentes, ou não, nos discursos, o que fortaleceu o conteúdo apreendido das falas dos líderes comunitários em uma perspectiva de aproximação entre as questões de saúde e seus determinantes sociais.

A partir desta fase inicial, também foi possível a definição das localidades que receberiam a etapa seguinte da atividade de campo, as visitas domiciliares. Este segundo momento de coleta de dados ocorreu por meio da visitação de todos os domicílios pertencentes às microrregiões previamente definidas, objetivando o preenchimento dos questionários, a observação em campo e a captação dos materiais para as análises laboratoriais - amostras de água de consumo, fezes e cabelo humano.

Durante a realização de visitas domiciliares, os participantes tiveram a oportunidade de responder as questões de modo privativo e respeitou-se a rotina familiar. Acrescenta-se que o questionário aplicado nesta segunda etapa do trabalho de campo foi do tipo estruturado, abrangendo as variáveis do estudo. As questões foram respondidas por meio da escolha, dentre as alternativas apresentadas, da opção que mais se adequou à realidade do morador entrevistado. Este tipo de instrumento tem sua aplicabilidade associada a trabalhos que, como 
este, busca abordar questões correlatas às características epidemiológicas e sanitárias de uma população, já que é descrito como conjunto ordenado e consistente de perguntas fechadas a respeito de variáveis ou de situações que se deseja medir, descrever ou analisar ${ }^{(195)}$.

No que concerne à estruturação do instrumento tipo questionário, infere-se que este foi elaborado com cinquenta e dois itens distribuídos em quatro eixos relacionados à caracterização de dados acerca dos moradores entrevistados: identificação do participante; local de domicílio; acesso a bens e serviços em saúde; e, tradição étnica e cultural.

A observação direta transcorreu durante a realização das oficinas de trabalho e, também, por ocasião de visitas à comunidade quilombola Kalunga em questão. Os observadores registraram evidências sobre o espaço geográfico e social dos quilombos, atentando, especialmente, para as condições higiênico-sanitárias (interface saúde-ambiente). Essas evidências, geralmente, são úteis para prover informações adicionais sobre o tópico em estudo $^{(196)}$. Acrescenta-se que no decorrer do processo de observação direta também foram coletados dados visando à caracterização dos resíduos sólidos e seus subtipos presentes na região peridomiciliar das residências.

Com vistas a assegurar a fidedignidade dos dados coletados, manteve-se a preocupação de, além da utilização de roteiro bem definido no protocolo da pesquisa, também, contar com o recurso de mais de um observador para cada casa visitada. Após as observações, os dados coletados foram analisados com o objetivo de reduzir a ocorrência de possíveis discrepâncias.

Os dados relativos à coleta de amostras para análise laboratorial englobaram os seguintes materiais: água destinada ao consumo humano para investigação de possível contaminação por excretas de animais de sangue quente, incluindo o homem; amostras de cabelo de moradores visando a detecção de possível contaminação por mercúrio, principalmente em sua forma de apresentação orgânica, visando revelar indício de contaminação ambiental; amostras de fezes humanas objetivando a identificação de possíveis infestações em moradores por parasitos intestinais; tecido muscular de peixe visando-se identificar metal pesado.

As coletas dos materiais para as análises laboratoriais foram realizadas e/ou supervisionadas pelos pesquisadores seguindo método próprio e protocolo padrão para cada material. Para evitar riscos de alteração na natureza microbiana ou química do material 
coletado, foi empregada, após cada coleta e durante toda a fase de acomodação e transporte, massa de solução criogênica (gelo reciclável) equivalente a três vezes a massa de cada grupo de amostras mantidas em caixas isotérmicas distintas.

A adoção de diferentes estratégias na produção dos dados da pesquisa contribui diretamente com uma maior densidade das informações estruturadas para a análise e, por conseguinte, na qualidade final dos resultados do estudo ${ }^{(197)}$.

\subsubsection{Visando responder o primeiro objetivo específico}

Por ocasião da realização dos eventos religiosos e culturais típicos dos quilombolas Kalungas, foi efetuado convite à comunidade para a realização de oficinas de trabalho.

As atividades das oficinas transcorreram no mês de setembro de 2012, de acordo com agendamento prévio realizado por intermédio dos líderes comunitários e com a colaboração dos agentes de saúde locais. As localidades apontadas para a realização das atividades foram Engenho II, no município de Cavalcante, Ema e Limoeiro, no município de Teresina de Goiás, e Riachão, no município de Monte Alegre.

A oficina de trabalho em cada município contou com a participação do líder comunitário local e de representantes dos moradores, sendo um total de treze participantes no município de Teresina de Goiás, quatorze no município de Monte Alegre e de onze no município de Cavalcante. A preocupação com o quantitativo de participantes fez menção exclusiva à dinâmica de desenvolvimento da oficina de trabalho, uma vez que, em se tratando da coleta de dados, o critério de saturação proporcionou o tamanho da amostra ${ }^{(198)}$.

Em cada oficina foi aplicado um questionário com questões abertas cujas respostas foram obtidas coletivamente. Este recurso visou fomentar, entre os moradores, a discussão sobre a interface saúde e ambiente, bem como propiciar a reunião de substrato, por meio da observação direta, para a caracterização do perfil socioeconômico (renda e estado civil), demográfico (tipo de moradia), epidemiológico (idade, sexo, ocupação) e sanitário ambiental (procedência e tratamento da água de consumo, destino dado aos resíduos sólidos) da Comunidade Kalunga.

Tal atividade possibilitou a realização coletiva da entrevista inicial e a identificação das localidades para a segunda etapa das visitadas domiciliares, com aplicação dos 
questionários individuais e coleta de materiais para as análises laboratoriais. Assim, um importante produto das oficinas de trabalho foi a definição, a partir das falas dos próprios quilombolas Kalungas, dos locais nas três comunidades para a realização do procedimento das visitas domiciliares na sequência da etapa de coleta de dados.

Cada micro região indicada foi totalmente percorrida e teve todas as casas visitadas. Contudo, nem todos os componentes de todas as famílias residentes foram entrevistados ou forneceram material para exame laboratorial parasitológico, respeitando-se o critério de participação voluntária nas etapas do estudo. Nesta ocasião foram coletadas amostras da água de consumo para análise microbiológica e de cabelo dos moradores para a quantificação do teor de mercúrio, com vistas à monitorização dos níveis deste metal pesado considerando-se a singularidade da população Kalunga e a relevância das ações em saúde que resultam de demandas da própria comunidade.

\subsubsection{Visando responder ao segundo objetivo específico}

a) Moradores: Os moradores e líderes comunitários Kalungas compuseram a amostra do estudo tanto nas atividades do grupo de trabalho (oficinas) por intermédio das entrevistas coletivas nas quais foram identificados, por meio de relato, quais eram os problemas de saúde mais prevalentes que ocorriam na população, quanto na etapa das visitas domiciliares, quando foram coletados os dados acerca da caracterização socioeconômica, demográfica, epidemiológica e sanitário-ambiental por meio de questionário semiestruturado.

A justificativa para a inclusão de entrevistas individuais com as lideranças comunitárias se alicerça na busca de maior fidedignidade, especialmente na leitura dos dados estatísticos, haja vista que estes líderes se destacam pelo conhecimento amplo acerca das condições de vida da comunidade. Também se destacam pela proximidade com que se relacionam com as demais famílias quilombolas e pelo modo com que operam, constantemente, enquanto mediação entre suas comunidades e as instâncias de poder e governo.

b) Abastecimento de água: Foram identificadas as diferentes fontes de abastecimento de água utilizada pelos moradores, bem como suas formas de acondicionamento e tratamento.

c) Análise microbiológica da água para consumo: Foram coletadas amostras de água para consumo humano em diferentes locais de cada município. Os pontos de coleta foram 
selecionados a partir de uma análise primeira dos dados obtidos nas oficinas de trabalho e entrevistas realizadas com os líderes comunitários e moradores das regiões de Cavalcante, Teresina de Goiás e Monte Alegre.

Para a seleção dos locais de coleta de amostra da água de consumo (fontes, rios, poços), levou-se em consideração critérios ambientais e sanitários: aglomerados de domicílios; áreas próximas a esgotamento in natura; e, áreas próximas a lavouras. A sistemática de coleta e de preservação das amostras de água seguiu a metodologia proposta no Standard Methods for the Examination of Water and Wastewater ${ }^{(199)}$, no que tange aos parâmetros para a realização de análise microbiológica.

A análise microbiológica da água foi realizada segundo Técnica de Tubos Múltiplos. Os testes foram realizados em parceria com o Instituto de Biologia da Universidade de Brasília - Laboratório de Microbiologia Molecular. A realização das análises buscou estudar a ocorrência de microrganismos em amostras da água para consumo humano, utilizada pela comunidade Kalunga. Para tanto, foi determinado o NMP (número mais provável) de coliformes totais e coliformes termotolerantes, de acordo com três etapas:

$1^{a}$ Etapa - Análise Presuntiva: Foram semeados em triplicata $10 \mathrm{~mL}$ da amostra em tubo de ensaio (20x200) contendo $10 \mathrm{~mL}$ de caldo lauril sulfato na concentração dupla, ou seja, duas vezes a mesma medida do caldo para cultivo $(71,2 \mathrm{~g} / 1 \mathrm{~L})$, com tubo de Duhran invertido (boca para baixo), permitindo a visualização dos gases emitidos pelos possíveis microrganismos.

Em seguida, foi semeado em triplicata $1 \mathrm{~mL}$ da amostra em tubo de ensaio (18x150) contendo $9 \mathrm{~mL}$ de caldo lauril sulfato com concentração simples $(35,6 \mathrm{~g} / 1 \mathrm{~L})$, com tubo de Duhran também invertido. Por fim, foi semeado em triplicata $0,1 \mathrm{~mL}$ da amostra em tubo de ensaio (18x150) contendo 9,9 mL de caldo lauril sulfato com concentração simples, com o tudo de Duhran também invertido.

Após todas as amostras serem semeadas, estas foram incubadas em estufa de cultura a $37^{\circ} \mathrm{C}$, por 24 horas. Aguardado o primeiro crescimento bacteriano, foi realizada leitura, na qual se observou a presença de turvação no meio e gás nos tubos de Duhran, indicativos da presença de coliformes totais. Foram efetuados registros de quais tubos houve o crescimento, e quais as diluições. 
$2^{a}$ Etapa - Análise Confirmatória - NMP de coliformes totais: Foram inoculadas as amostras que tiverem crescimento bacteriano (uma amostra de cada diluição). Para tanto, foram utilizadas alças de platina em tubo de ensaio (18x150) contendo $10 \mathrm{~mL}$ em triplicata do caldo verde brilhante bile (40 g/1 L) e também tubo de Durhan e, depois de entubada, em estufa a $37^{\circ} \mathrm{C}$ por $24 \mathrm{~h}$. A leitura do crescimento foi analisada, anotando-se quantos tubos apresentaram crescimento, em cada diluição utilizando-se, para tal, a tabela própria para NMP.

$3^{a}$ Etapa - Análise Confirmatória - NMP de coliformes termotolerantes: Foi realizada no mesmo dia, seguindo a segunda etapa na qual foram incubadas amostras que tiveram crescimento bacteriano (uma amostra de cada diluição). Utilizou-se alça de platina, em tubo de ensaio (18x150) contendo $10 \mathrm{~mL}$ em triplicata EC (Escherichia coli) (37 g/1 L), e também tubo de Durhan. Em seguida, as amostras foram incubadas em banho-maria a $44,5^{\circ} \mathrm{C}$ por $24 \mathrm{~h}$. A leitura do crescimento foi analisada, anotando-se quantos tubos apresentaram crescimento, em cada diluição e utilizando-se a tabela própria para NMP.

d) Amostras de tecido muscular estriado esquelético de peixes consumidos na região: As espécies analisadas foram coletadas nos três municípios - Cavalcante, Teresina de Goiás e Monte Alegre - em pontos identificados, de acordo com os resultados das oficinas. A captura foi realizada com anzóis nos locais onde os moradores costumam desenvolver suas atividades pesqueiras cotidianas. Os peixes coletados foram mantidos em tanques com água até o momento da retirada dos tecidos. Contou-se com o apoio de moradores kalungas, em cada município, para a realização desta etapa. Dos exemplares, foram anotados dados referentes ao comprimento total, comprimento padrão e peso total.

As amostras de tecido muscular retiradas dos espécimes de peixes capturados foram armazenadas em sacos plásticos devidamente etiquetados e mantidos congelados, até o momento da análise junto ao Laboratório de Química Analítica e Ambiental, da Universidade de Brasília. As análises foram realizadas no período de janeiro a maio de 2013. A metodologia de análise laboratorial utilizada foi baseada na técnica de Deitz, Sell e Bristol $^{(200)}$, com pequenas modificações.

A determinação do mercúrio total requer um processo prévio de digestão ou mineralização com destruição da matéria orgânica das amostras, em que se consegue 
transformar os compostos de mercúrio para a forma inorgânica $\left(\mathrm{Hg}^{+2}\right)$, eliminando interferências na análise por absorção atômica.

Assim, na preparação das amostras de tecido muscular para análise química propriamente dita, foi utilizada digestão ácida em todas as amostras. $\mathrm{O}$ processo de digestão foi realizado utilizando-se $0,4 \mathrm{~g}$ de amostra, 4,0 $\mathrm{mL}$ de $\mathrm{HNO}_{3}$ concentrado $(65 \%)$ e 2,0\% de $\mathrm{H}_{2} \mathrm{O}_{2}(30 \%)$. Após a digestão, o material foi resfriado por quinze minutos em capela e, em seguida, em água e gelo por mais vinte minutos. Após o completo resfriamento das amostras digeridas, cada uma foi transferida para um balão volumétrico de $25 \mathrm{~mL}$.

As determinações de mercúrio foram inferidas por meio de Espectroscopia de Absorção Atômica de Vapor Frio CV-AAS, utilizando monitor de mercúrio modelo MM 3200, da Thermo Separation Products. Essa técnica de análise permite a detecção de teores de mercúrio entre parte por bilhão (ng/L) até parte por milhão (mg/L).

e) Amostras de cabelo humano: A concentração de mercúrio no cabelo é frequentemente usada como um marcador biológico para exposição ao metilmercúrio, porque reflete a concentração no sangue na ocasião em que o cabelo foi formado ${ }^{(201)}$. No estudo em questão, tal abordagem é apropriada, já que, em caso de não haver exposição ao mercúrio inorgânico externo ou vapor de mercúrio, quase todo o mercúrio no cabelo está na forma de metilmercúrio. Desta forma, o nível de exposição ao metilmercúrio da dieta pode ser avaliado medindo-se o mercúrio total, nos cabelos. Além disso, as amostras de cabelo provêm de um método de amostragem não invasivo. A concentração de mercúrio detectada no cabelo é geralmente 250-300 vezes a concentração no sangue. Uma vez que o cabelo cresce a uma taxa de aproximadamente um centímetro por mês, é possível a avaliação da exposição passada e acumulada ao longo da vida, levando-se em consideração os períodos no qual ocorreram de cortes do cabelo ${ }^{(202)}$.

Nesta fase da pesquisa e com a finalidade de garantir o rigor metodológico no desenvolvimento das análises, foram seguidas as recomendações da International Atomic Energy $^{(203)}$. Assim, as amostras de cabelo foram obtidas da área occipital da cabeça, cortados rente ao couro cabeludo e incluindo pelo menos vinte fios de cabelo e aproximadamente 10 $\mathrm{mg}$ ao todo. Os fios do cabelo amostrado foram amarrados juntos pelo final da raiz com uma linha de algodão, de forma que este ponto pudesse ser identificado. Em seguida, cada amostra foi armazenada em um saco de polietileno à temperatura ambiente e devidamente identificada. 
Para a etapa de análise laboratorial, propriamente dita, as amostras de cabelo foram previamente lavadas e homogeneizadas. O mercúrio total foi analisado por espectrometria de absorção atômica por vapor frio utilizando monitor de mercúrio modelo MM 3200 da Thermo Separation Products. Em espectrometria de absorção atômica por vapor frio, o mercúrio é convertido em vapor de mercúrio elementar, o qual é introduzido em uma célula de absorção e a absorção é medida a 253,7 nm para determinação da quantidade. Este método é muito mais sensível quando comparado ao convencional, a espectrometria de absorção atômica por chama.

f) Exame parasitológico de fezes: Foi realizado com os membros das famílias residentes nas localizações referidas como área de grande número de casos de doenças. Esta identificação foi o resultado do cruzamento dos dados referentes às oficinas de trabalho com as entrevistas e as análises das amostras da água de consumo da população Kalunga.

Os recipientes para coleta das fezes foram entregues nos respectivos domicílios, após explicação sobre o projeto e orientação de como proceder a coleta. As matérias fecais foram conservadas em potes contendo MIF (Merthiolate-Iodo-Formol). As amostras foram recolhidas na semana seguinte à realização da visita domiciliar e acondicionadas em depósito próprio para transporte, e encaminhadas ao Laboratório de Análises Clínicas do Curso de Farmácia da Faculdade Sena Ayres para realização do exame coproscópico.

O diagnóstico parasitológico foi realizado de maneira apropriada, com maior sensibilidade e especificidade para a detecção dos parasitas intestinais, uma vez que dele depende o tratamento específico ${ }^{(204)}$. Neste sentido, durante as análises do material fecal, primeiramente foi utilizado o método de Hoffman-Pons-Janer ${ }^{(205)}$. Para tanto, as amostras foram homogeneizadas e filtradas para cálices de sedimentação, sendo completado o volume com água e deixado a sedimentar por vinte e quatro horas. Cada sedimento foi examinado microscopicamente por dois observadores de forma independente.

Nos casos em que os resultados do teste de Hoffman indicaram a existência de grande quantidade de ovos de helmintos, também foi utilizado o método parasitológico de Kato-Katz (três lâminas), que se caracteriza por seu componente quali-quantitativo. Tal método é muito usado para o diagnóstico de helmintos, uma vez que, neste tipo de teste, alguns helmintos como Schistosoma mansoni, Ascaris lumbricoides, Trichuris trichiura e ancilostomatídeos podem ter sua carga parasitária avaliada ${ }^{(206)}$. A aplicação de diferentes métodos de exames de 
fezes tornou-se necessária tendo em vista a variabilidade morfológica e biológica apresentada pelos parasitas $^{(204)}$.

Aos membros da Comunidade Kalunga que apresentaram resultado negativo, foi facultada a realização de um novo ciclo de exame, como objetivo confirmatório. Após isto, e por meio de parceria estabelecida previamente com os agentes comunitários de saúde das comunidades, todos os moradores com resultado positivo foram encaminhados à unidade de saúde local. Foi disponibilizada, junto aos ambulatórios das localidades, medicação específica para tratamento tanto dos moradores infestados quanto dos demais residentes por unidade domiciliar com caso positivo para infestação parasitológica. Destaca-se ainda que as unidades de saúde de referência das comunidades foram informadas sobre os resultados, com vistas a contribuir com futuras orientações sobre a prevenção das parasitoses e com a supervisão e acompanhamento do tratamento antiparasitário.

g) Produção e destinação do lixo domiciliar: A questão dos resíduos sólidos demanda atenção pela sociedade contemporânea, pois estes, além de se caracterizar em um dos principais problemas ambientais da atualidade, seu acúmulo também é capaz de se consolidar em um grave problema de saúde pública ${ }^{(207)}$.

Com o objetivo de melhor conhecer a realidade à qual a população Kalunga se insere, é de suma importância a produção de dados acerca da composição e qualidade do resíduo gerado, e suas formas coleta e disposição, visando minimizar os impactos na saúde e no meio ambiente e, por conseguinte, contribuir com a qualidade de vida da comunidade. Vale ressaltar que a abordagem qualitativa sobre os resíduos gerados pela comunidade Kalunga foi utilizada objetivando a caracterização desse material em relação aos tipos produzidos e proporções.

Assim, para a captação dos dados relativos à produção e destinação do lixo, foram considerados tanto fatores que influenciam na origem desses resíduos sólidos domiciliares, quanto os que dizem respeito a sua formação propriamente dita: número de habitantes, área relativa de produção, hábitos e costumes da população, grau de escolaridade, poder aquisitivo, entre outros.

Os resíduos sólidos domiciliares foram avaliados diretamente no entorno da moradia de cada família Kalunga selecionada para esta etapa do estudo, sendo a área de abrangência determinada pela própria especificação dos moradores. Tais observações estão de acordo com 
a NBR n. ${ }^{\circ}$ 10.007/2004, que propõe que a amostra de resíduo sólido a ser estudada deve ser obtida por meio de um processo de amostragem que garanta as mesmas características e propriedades da massa total do resíduo ${ }^{(208)}$

Inicialmente, realizou-se a caracterização visual dos materiais encontrados nos locais de estudo. Em seguida, com a finalidade de estimar a porcentagem existente de cada constituinte, procedeu-se a análise qualitativa das amostras. Os resíduos foram separados manualmente e selecionados os subtipos constituintes da amostra de acordo com os componentes mais comumente encontrados como: matéria orgânica, metal ferroso, borracha, papel, metal não ferroso, couro, papelão, alumínio, pano/trapo, plástico rígido, vidro, madeira, ossos, plástico mole, cerâmica e agregados finos ${ }^{(209)}$. Os achados foram registrados em formulário específico (Apêndice C).

h) Destinação dos dejetos humanos: Foi verificada, junto aos moradores, a existência ou não de instalações destinadas para os dejetos humanos, considerando os tipos existentes nas localidades ou mesmo se os dejetos são lançados diretamente ao meio ambiente. Para tanto, os dados foram coletados com a utilização de questionário com itens específicos para essa finalidade.

\subsection{VARIÁVEIS DO ESTUDO}

Neste estudo, selecionaram-se as partes do questionário que continham as variáveis mais adequadas ao delineamento dos perfis demográfico, socioeconômico, sanitárioambiental, epidemiológico e de saúde da população sujeito. Foram incluídos na estruturação dos perfis os dados provenientes das análises laboratoriais e do instrumento de caracterização dos resíduos sólidos.

Para formar o perfil demográfico foram selecionadas as variáveis: município de moradia, povoado, tipo de vínculo com a comunidade, sexo, idade, estado civil, ocupação, quantidade de filhos e quantas pessoas moram na residência.

Para o perfil socioeconômico foram selecionadas as variáveis que diziam respeito às condições da moradia: tipo de casa, piso interno, telhado, número de cômodos, tipo de iluminação, meios de comunicação, religião, atividades de lazer, espaço comunitário, tipo de alimento predominante nas refeições, forma de deslocamento, atividade econômica, bens duráveis, renda mensal e familiar e escolaridade dos entrevistados. 
Para o perfil sanitário-ambiental foram selecionadas as variáveis: procedência da água de consumo, procedência da água de beber, realização de tratamento com a água, água encanada dentro de casa, rede de esgoto, presença de coliformes termotolerantes na água de consumo humano, destino dos dejetos fisiológicos, presença de banheiro dentro de casa, destinação do lixo, realização de alguma separação de tipos de lixo, presença de infestação intestinal, tipo de parasito causador da infestação, consumo de peixe na alimentação, concentração de mercúrio no cabelo humano e concentração de mercúrio no tecido muscular de peixes.

E, por fim, para o perfil de saúde selecionaram-se as variáveis que diziam respeito ao acesso a serviços de saúde, tais como o acesso ao serviço, o tipo de serviço acessado, localização dos serviços de saúde, profissional responsável pelas demandas, principais problemas de saúde; condições de saúde da população, tais como se a pessoa tem ou já teve algum problema de saúde, as doenças referidas pelos sujeitos, se fizeram ou não tratamento para as doenças referidas, onde buscou assistência à saúde, quem na casa teve a doença e se associa a doença a algum evento; e variáveis que demonstraram os hábitos e estilo de vida da coletividade no que diz respeito aos hábitos de fumar e consumo de bebida alcoólica.

\subsection{ANÁLISE DAS VARIÁVEIS}

Esta etapa do desenvolvimento da pesquisa foi realizada em parceria com a University College London - Department of Epidemiology and Public Health. Os dados foram compilados em um banco de dados próprio e em seguida procedeu-se as proposições e correlações estatísticas com subsídio do aplicativo estatístico IBM Statistical Package for the Social Sciences - SPSS, versão 21.

Para análise dos dados e estudo sobre a associação entre variáveis, adotou-se o teste qui-quadrado em nível de significância de 5,0\%, intervalo de confiança de $95 \%$ e o cálculo de resíduos ajustado para as células de tabelas de contingência.

\subsection{CONSIDERAÇÕES ÉTICAS}

O projeto foi submetido à apreciação do Comitê de Ética em Pesquisa da Faculdade de Ciências da Saúde da Universidade de Brasília, recebendo parecer favorável de número 070/2012 (Anexo 2). 
Todo o desenvolvimento do estudo ocorreu em conformidade com o preconizado pela Resolução n. ${ }^{\circ}$ 466/2012, do Conselho Nacional de Saúde. Para tanto se respeitou a proteção dos participantes, a responsabilidade primordial do pesquisador e a informação pertinente sobre a pesquisa.

Foi reforçado o princípio da participação autônoma, da privacidade, da confidencialidade e sigilo dos dados. Aos participantes foram explicados os objetivos da pesquisa e aqueles que concordaram foram informados, esclarecidos e convidados a assinarem o TCLE. No caso dos indivíduos menores de idade, a autorização para a participação foi conferida pelos pais ou por representante legal. 


\section{CAPÍTULO 6}




\section{RESULTADOS E DISCUSSÃO}

As medições referidas viabilizaram a identificação de associações no que tange às caracterizações das condições de saúde dos entrevistados e da análise dos bens de consumo, como a água e peixes Os limites do presente estudo referem-se à metodologia utilizada, delineamento transversal abordagem, a qual não possibilita estabelecer relações de causas e efeito entre variáveis, em relação à temporalidade. Contudo, a partir de minha inserção no convívio da comunidade, foi possível a realização de mensurações pontuais e sem exigências quanto à sequencialidade temporal. Outra possível limitação refere-se ao tamanho da amostra, destacando-se a validade da realização de estudos censitários envolvendo populações tradicionais como a Comunidade Kalunga. Contudo, quando da opção metodológica adotada nesta pesquisa, foi devida às especificidades da população pesquisada, principalmente em relação à distribuição espacial, singularizada no relativo isolamento geográfico.

Assim, os resultados deste estudo têm sua aplicabilidade prática expressa na viabilidade de sua utilização por autoridades sanitárias, enfermeiros e outros profissionais de saúde pública que visem à elaboração de programas destinados à promoção de saúde e qualidade de vida dos membros das comunidades que, historicamente, vêm sendo excluídos do acesso aos bens de consumo normalmente disponibilizados a outras populações, especialmente a urbana. Ademais, este estudo gerou informações pioneiras que podem ser incorporadas em pesquisas futuras, ou ainda na aplicação de medidas que contribuam para a melhoria dos indicadores sociais e de saúde, pois estes são precários e, por isso, é necessário envidar esforços que possam mudar positivamente a situação detectada.

O capítulo que se propõe a apresentar e discutir os resultados foi organizado em três partes: a primeira trata da caracterização da população - variáveis socioeconômicodemográficas e aspectos epidemiológicos; a segunda descreve o perfil parasitológico dos moradores de acordo com as diferentes espécies de infestação detectadas; e, na terceira parte, são trabalhadas as condições ambientais e sanitárias de moradores entrevistados e alguns aspectos relacionados à saúde desse grupo quilombola. 


\subsection{ASPECTOS EPIDEMIOLÓGICOS} SOCIOECONÔMICO-DEMOGRÁFICOS

Nos três municípios pesquisados, o quantitativo de moradores pesquisados foi de 201 indivíduos, pertencentes a 63 famílias. No que tange à composição familiar, constatou-se que os núcleos familiares são numerosos, com média de 3,8 pessoas por família. Este achado é similar a estudos realizados em 2004 e 2009, onde o número médio de membros por unidade familiar foi de 3,9 e 3,7, respectivamente ${ }^{(210,101)}$. Ademais, 67,7\% $(\mathrm{n}=21)$ dos respondentes em idade reprodutiva relataram possuir três ou mais filhos e, destes, 26,15\% $(n=10)$ afirmaram ter cinco ou seis filhos.

As proposições anteriores acerca de arranjos familiares contribuem para o entendimento dos achados relativos ao número de moradores por residência, sendo a maioria das casas habitadas por cinco ou mais moradores $(n=133 ; 66,2 \%)$ e por membros de uma única família ( $n=197 ; 98,0 \%)$; a explicação pode residir no fato de tradicionalmente, quando um filho se casa, uma nova casa é construída com a ajuda dos vizinhos em uma área próxima à casa do pai ${ }^{(211)}$.

Com relação ao tipo de vínculo participativo na comunidade, 1,5\% (n=3) identificaram-se como líderes comunitários, enquanto os outros 98,5\% ( $\mathrm{n}=198)$ dos sujeitos apresentaram-se como membros da comunidade. Ao todo, 15,4\% $(\mathrm{n}=31)$ dos respondentes relataram que residiam no município de Cavalcante - Engenho II; 49,3\%, (n=99) afirmaram residir em Monte Alegre - Riachão; e, 35,7\% (n=71) em Teresina de Goiás, sendo que neste último município contou-se tanto com a participação de moradores do povoado de Ema/Soledade $(n=48 ; 23,9 \%)$ quanto de Limoeiro $(n=23 ; 11,4 \%)$, pois não existe uma fronteira geográfica delimitadora entre os povoados.

Na Tabela 1, é apresentada distribuição dos moradores Kalungas participantes no estudo, segundo município de localização e povoados de residência. 
Tabela 1 - Moradores segundo município de residência no Sítio Histórico e Patrimônio Cultural Kalunga, em

\begin{tabular}{lcc} 
& 2012 & \\
\hline$\quad$ Município/Povoado & $\mathrm{n}$ & \\
\hline Cavalcante & 31 & 15,4 \\
$\quad$ Engenho II & 31 & 15,4 \\
Subtotal & & \\
Teresina de Goiás & 48 & 23,9 \\
$\quad$ Ema/Soledade & 23 & 11,4 \\
$\quad$ Limoeiro & 71 & 35,3 \\
Subtotal & & \\
Monte Alegre & 99 & 49,3 \\
$\quad$ Riachão & 99 & 49,3 \\
Subtotal & 201 & 100 \\
Total Geral & &
\end{tabular}

Com base na análise da Tabela 1, verifica-se que a maior participação dos quilombolas, na pesquisa, ocorreu no município de Monte Alegre, seguidos por Teresina de Goiás e Cavalcante. Uma possível explicação para tal situação pode residir no fato de que, neste município, os Agentes Comunitários de Saúde cooperaram mais significativamente na etapa de organização e preparativos para a realização das oficinas de trabalho e visitas domiciliares. O envolvimento direto dos agentes de saúde em ações de disseminação de informação e na organização das atividades junto aos moradores pode ter proporcionado maior efetividade de participação na pesquisa.

As principais características sociodemográficas e epidemiológicas da população são mostradas na Tabela 2. 
Tabela 2 - Perfil epidemiológico demográfico e social dos moradores kalungas, em 2012

\begin{tabular}{|c|c|c|c|c|}
\hline \multirow[b]{2}{*}{ Variáveis } & \multicolumn{4}{|c|}{ Municípios } \\
\hline & $\begin{array}{c}\text { Cavalcante } \\
\mathrm{n}(\%)\end{array}$ & $\begin{array}{c}\text { Teresina de Goiás } \\
\mathrm{n}(\%)\end{array}$ & $\begin{array}{c}\text { Monte Alegre } \\
\mathrm{n}(\%)\end{array}$ & $\begin{array}{l}\text { Total } \\
\mathrm{n}(\%)\end{array}$ \\
\hline \multicolumn{5}{|l|}{ Sexo } \\
\hline Masculino & $14(45,2)$ & $36(50,7)$ & $34(34,3)$ & $84(41,8)$ \\
\hline Feminino & $17(54,8)$ & $35(49,3)$ & $65(65,7)$ & $117(58,2)$ \\
\hline \multicolumn{5}{|l|}{ Faixa etária } \\
\hline Menos de 19 anos & $5(16,1)$ & $30(42,3)$ & $45(45,5)$ & $80(39,8)$ \\
\hline Entre $20-39$ anos & $18(58,1)$ & $14(19,7)$ & $30(30,3)$ & $62(30,8)$ \\
\hline Entre $40-59$ anos & $7(22,6)$ & $14(19,7)$ & $15(15,1)$ & $36(17,9)$ \\
\hline 60 anos ou mais & $1(3,2)$ & $13(18,3)$ & $9(9,1)$ & $23(11,5)$ \\
\hline \multicolumn{5}{|l|}{ Grau de escolaridade } \\
\hline Não alfabetizado & $11(35,5)$ & $35(49,3)$ & $53(53,5)$ & $99(49,3)$ \\
\hline Ensino fundamental incompleto & $13(42,0)$ & $32(45,1)$ & $44(44,5)$ & $89(44,3)$ \\
\hline Ensino fundamental completo & $5(16,1)$ & $2(2,8)$ & $2(2,0)$ & $9(4,5)$ \\
\hline Ensino médio incompleto & $1(3,2)$ & $2(2,8)$ & - & $3(1,5)$ \\
\hline Ensino médio completo & $1(3,2)$ & - & - & $1(0,5)$ \\
\hline \multicolumn{5}{|l|}{ Estado civil } \\
\hline Solteiro & $21(67,8)$ & $60(84,5)$ & $88(88,9)$ & $169(84,1)$ \\
\hline Casado & $9(29,0)$ & $5(7,1)$ & $3(3,1)$ & $17(8,5)$ \\
\hline Viúvo & - & $4(5,6)$ & $4(4,0)$ & $8(4,0)$ \\
\hline Outros & $1(3,2)$ & $2(2,8)$ & $4(4,0)$ & $7(3,5)$ \\
\hline \multicolumn{5}{|l|}{ Composição da prole } \\
\hline Nenhum filho & $1(3,2)$ & $5(7,1)$ & $4(4,0)$ & $10(5,0)$ \\
\hline 1 ou 2 filhos & $4(12,9)$ & $7(9,9)$ & $21(21,2)$ & $32(15,9)$ \\
\hline 3 ou 4 filhos & $11(35,5)$ & $4(5,6)$ & $13(13,1)$ & $28(13,9)$ \\
\hline 5 ou 6 filhos & $6(19,4)$ & $11(15,5)$ & $17(17,2)$ & $34(16,9)$ \\
\hline 7 ou mais filhos & $4(12,9)$ & $16(22,5)$ & $6(6,1)$ & $26(13,0)$ \\
\hline Não se aplica & $5(16,1)$ & $28(39,4)$ & $38(38,4)$ & $71(35,3)$ \\
\hline \multicolumn{5}{|l|}{ Religião } \\
\hline Católica & $26(83,9)$ & $52(73,2)$ & $81(81,8)$ & $159(79,1)$ \\
\hline Evangélica & $3(9,7)$ & $7(9,9)$ & - & $10(5,0)$ \\
\hline Sem religião formal & $2(6,4)$ & $12(16,9)$ & $18(18,2)$ & $32(15,9)$ \\
\hline
\end{tabular}

A distribuição por sexo possibilitou identificar uma discreta disparidade, sendo que $58,2 \%(n=117)$ dos componentes do estudo foram mulheres, enquanto 41,8\% ( $n=84)$ eram homens. No Brasil, a maior proporção de mulheres pode estar relacionada à tendência geral encontrada em nosso país, 96 homens para cada 100 mulheres, enquanto que no Estado de Goiás, verificou-se uma proporção de 98 homens para cada 100 mulheres ${ }^{(212)}$. Os achados podem estar relacionados à própria dinâmica metodológica de coleta de dados, onde o ente feminino, por se caracterizar, na maioria das vezes, responsável pelo componente doméstico, poderia mais facilmente ser encontrado no domicílio por ocasião das visitas dos pesquisadores.

O município de Teresina de Goiás foi o que apresentou a maior proximidade entre as proporções de homens e mulheres, enquanto que em Monte Alegre verificou-se maior desproporção na distribuição dos moradores estudados segundo a variável sexo. 
Com relação à faixa etária, os resultados mostraram que a idade dos participantes variou entre zero e 87 anos. Houve o predomínio do grupo etário formado por crianças e adolescentes, de zero a 19 anos $(n=80 ; 39,8 \%)$, seguido pelos grupos de adultos com idades entre 20 e 39 anos $(n=62 ; 30,8 \%)$ e com idades entre 40 e 59 anos $(n=36 ; 17,9 \%)$. Por último, constatou-se que pessoas com mais de 60 anos representaram 11,5\% $(n=23)$ do universo pesquisado.

Os achados sobre as diferentes faixas etárias dos moradores se assemelham aos que ocorrem com o total geral da população do Estado de Goiás. Segundo dados do Censo Demográfico $2010^{(213)}$, a população goiana residente de 0 a 19 anos representa $32,9 \%$ da população, de 20 a 39 anos, 35,3\%, de 40 a 59 anos, 22,5\%, e a população acima de 60 anos era de 9,3\%. A principal diferença apresenta-se com relação ao grupo etário de 20 a 39 anos, que dentre a população Kalunga tende a ser menor do que o seu correspondente na população geral do Estado de Goiás. Este fenômeno pode ser atribuído às migrações da população jovem em busca de melhores condições de vida e trabalho.

A associação entre as variáveis faixa etária e sexo possibilitou inferir que, no estudo, o grupo de Kalungas menores de 19 anos apresenta percentuais bem semelhantes: 40,5\% de homes (n=34) e 39,3\% de mulheres (n=46). Já nas faixas etárias de 20 a 39 anos e de 40 a 59 anos, as proporções da distribuição por sexo mostraram certa discrepância: 25,0\% (n=21) de homens e 35,0\% $(n=41)$ de mulheres; e, $22,6 \%(n=19)$ pertencentes ao sexo masculino e $14,6 \%(n=17)$ ao feminino, respectivamente. Entre o grupo de idoso, 60 anos ou mais, a distribuição por sexo voltou a apresentar similaridade, com 11,9\% $(n=10)$ dos respondentes homens e $11,1 \%(n=13)$ mulheres. Não houve associação estatística significativa $(p=0,710)$ na tabulação cruzada entre as variáveis supramencionadas.

Entre os moradores Kalungas é possível destacar os baixos graus de escolaridade, pois quase a metade da população $(n=99 ; 49,3 \%)$ pertence ao grupo de não alfabetizados. Este achado mostra a elevada incidência de analfabetismo entre a população Kalunga, uma vez que este valor está bem acima do descrito pelo IBGE em sua Síntese de Indicadores Sociais - uma análise das condições de vida da população brasileira em 2012 ao apontar que, entre os moradores das zonas rurais brasileiras, a taxa de analfabetismo é o dobro da média nacional, calculada em $8,7 \%{ }^{(212)}$. 
Observa-se que o analfabetismo se reflete em realidade comum no meio rural brasileiro e afeta, principalmente, as pessoas mais velhas devido à falta de escolas no passado $^{(110)}$. A maioria das crianças e adolescentes Kalungas (7 a 15 anos) sabe ler e escrever $(73,4 \%)$, enquanto que $92,3 \%$ dos idosos não sabem ler ou escrever.

O quadro apresentado pode sugerir uma tendência à diminuição do analfabetismo entre as gerações mais novas; contudo, ainda persiste a manutenção da pobreza, o comprometimento das futuras gerações associadas aos baixos índices de escolaridade e as fragilidades com relação ao ensino na Comunidade Kalunga.

Avelar e Vicente de Paula ${ }^{(214)}$ descrevem o maior acesso das crianças às escolas fixadas na zona rural dos municípios Kalungas e destacam que, muitas vezes, as escolas rurais se caracterizam por apresentar deficiências e limitações quanto à formação profissional dos educadores, e quanto à própria disponibilidade de recursos materiais, físicos e estruturais.

Observa-se que, dentre os moradores entrevistados, 21,9\% $(n=44)$ referem à presença de escola apenas fora do povoado onde residem, e 79,6\% ( $n=160)$, quando questionados sobre o grau de escolaridade oferecido nas unidades educacionais em questão, mencionaram que estas oferecem o ensino fundamental, muitas vezes incompleto. A situação descrita é corroborada pelo fato de que, entre os Kalungas que sabem ler e escrever, 44,3\% (n=89) cursaram apenas o ensino fundamental incompleto; 4,5\% (n=9) concluíram o ensino fundamental; $1,5 \%(n=3)$ cursou o ensino médio incompleto; e apenas uma pessoa $(0,5 \%)$ completou todo o ensino médio. Não houve referências à formação superior mesmo que incompleta ou em andamento.

Assim, tanto as grandes distâncias a serem percorridas a pé para chegar às escolas, quanto a sua oferta insuficiente - na maioria das vezes só incluem as séries iniciais do ensino fundamental - podem ser citadas como possíveis agentes capazes de gerar dificuldades educacionais entre os moradores quilombolas, uma vez os jovens que ultrapassam a barreira das longas caminhadas têm de se mudar para a sede dos municípios ou para grandes centros, como Brasília e Goiânia, visando completar os estudos ${ }^{(215)}$.

Ainda com relação à variável grau de escolaridade, destaca-se o fato de que no município de Cavalcante verificaram-se resultados singulares em relação ao total da amostra, uma vez que o grupo de moradores com ensino fundamental incompleto ( $\mathrm{n}=13 ; 42,0 \%)$ apresentou superioridade quando comparado ao grupo de não alfabetizados ( $\mathrm{n}=11 ; 35,0 \%)$. 
Com referência ao estado civil, verificou-se que 84,1\% ( $n=169)$ dos entrevistados declararam-se solteiros, sendo que, deste total, 26,4\% (n=53) também se caracterizaram como "amasiado", ou seja, refere viver em união consensual segundo nomenclatura de referência pelo IBGE. Assim, 57,7\% $(\mathrm{n}=116)$ da população Kalunga pesquisada caracterizaram-se, exclusivamente, pertencente ao grupo solteiro. Em seguida, identificou-se o grupo dos casados (casamento civil), com um total de 8,5\% ( $\mathrm{n}=17)$; viúvos com 4,0\% ( $\mathrm{n}=8)$; e, por fim, os que se autodeclaram separados com $3,5 \%$ das respostas $(n=7)$.

Com relação ao número de filhos, constatou-se que 29,9\% (n=60) dos respondentes afirmaram possuir cinco ou mais filhos, seguidos pelos com três ou quatro filhos $(\mathrm{n}=28$; $13,9 \%)$ e pelos que referem ter um ou dois filhos $(n=32 ; 15,9 \%)$. Apenas 5,0\% $(n=10)$ dos Kalungas mencionaram não ter filhos. Na Comunidade Kalunga, as proles, tradicionalmente, são numerosas, realidade que fica mais evidente quando enfocado apenas os Kalungas que já passaram ou estão em idade reprodutiva, uma vez que dentre este grupo 46,2\% (n=60) afirmam ter cinco ou mais descendentes diretos, dos quais $16,6 \%(n=10)$ são pais biológicos entre dez ou mais filhos.

Quando se comparam estes resultados obtidos com outras estimativas, verifica-se que as comunidades quilombolas estudadas apresentam níveis mais elevados de taxa de fecundidade total. Para fins de ilustração do proposto, pode-se citar que para a população brasileira em 2013, a taxa média era de 1,8 filhos, sendo o mesmo valor para a Região CentroOeste e de 1,7 em se tratando, especificamente, do Estado de Goiás ${ }^{(212)}$.

As religiões de origem cristã, católica e evangélica, predominaram entre os moradores entrevistados. Desses, 79,1\% $(\mathrm{n}=159)$ referiu professar a religião católica e 5,0\% $(\mathrm{n}=10)$ a evangélica. Os demais, $(n=32 ; 15,9 \%)$, afirmaram não seguir nenhuma religião formal. A maior proporção de católicos $(\mathrm{n}=81 ; 81,8 \%)$ foi encontrada em Monte Alegre, enquanto que a maior proporção de evangélicos foi verificada no município de Teresina de Goiás (n=7; $9,9 \%)$.

Nunes e Nazareno ${ }^{(216)}$ corroboram com o achado em relação ao catolicismo como principal religião professada nessa comunidade de remanescentes quilombolas, ao inferirem que os Kalungas, de uma maneira geral, se autodenominam católicos com devoção a vários santos e histórico cultural de festas ao longo do ano em homenagem a estes: São João, Nossa Senhora das Neves, Nossa Senhora D’Abadia, Nossa Senhora do Livramento, São Sebastião, 
Santo Antônio, Folia de Reis, Folia do Divino Espírito Santo, São Gonçalo e Nossa Senhora Aparecida.

Foi possível identificar a presença de forte significado estatístico na associação entre município de residência e as variáveis: faixa etária (teste qui-quadrado: $p=0,003$ ), grau de escolaridade (teste qui-quadrado: $\mathrm{p}=0,007$ ), estado civil (teste qui-quadrado: $\mathrm{p} \leq 0,001$ ), composição da prole (teste qui-quadrado: $p=0,002$ ) e religião (teste qui-quadrado: $p=0,015$ ).

Na Tabela 3, são mostradas as principais variáveis do perfil socioeconômico dos moradores da Comunidade Kalunga dos municípios de Cavalcante, Teresina de Goiás e Monte Alegre.

Tabela 3 - Características socioeconômicas dos quilombolas Kalungas, em 2012

\begin{tabular}{|c|c|c|c|c|}
\hline \multirow[b]{2}{*}{ Variáveis } & \multicolumn{4}{|c|}{ Municípios } \\
\hline & $\begin{array}{c}\text { Cavalcante } \\
\mathrm{n}(\%)\end{array}$ & $\begin{array}{c}\text { Teresina de Goiás } \\
\mathrm{n}(\%)\end{array}$ & $\begin{array}{c}\text { Monte Alegre } \\
\mathrm{n}(\%)\end{array}$ & $\begin{array}{l}\text { Total } \\
\mathrm{n}(\%)\end{array}$ \\
\hline \multicolumn{5}{|l|}{ Meio de deslocamento na comunidade } \\
\hline A pé & $17(54,9)$ & $49(69,0)$ & $65(65,7)$ & $131(65,2)$ \\
\hline Lombo de animal & $13(41,9)$ & $10(14,1)$ & $15(15,1)$ & $38(18,9)$ \\
\hline Outros (bicicleta, carro, moto, etc.) & $1(3,2)$ & $12(16,9)$ & $19(19,2)$ & $32(15,9)$ \\
\hline \multicolumn{5}{|l|}{ Alimento predominante nas refeições } \\
\hline Cultivado & $29(93,5)$ & $22(31,0)$ & $64(64,6)$ & $115(57,2)$ \\
\hline Industrializado & $2(6,5)$ & $49(69,0)$ & $35(35,4)$ & $86(42,8)$ \\
\hline \multicolumn{5}{|l|}{ Ocupação } \\
\hline Lavrador & $15(48,4)$ & $29(40,9)$ & $42(42,4)$ & $86(42,8)$ \\
\hline Dona de casa & $8(25,8)$ & $14(19,7)$ & $39(39,4)$ & $61(30,3)$ \\
\hline Estudante & $5(16,1)$ & $26(36,6)$ & $16(16,2)$ & $47(23,4)$ \\
\hline Outras atividades & $3(9,7)$ & $2(2,8)$ & $2(2,0)$ & $7(3,5)$ \\
\hline \multicolumn{5}{|l|}{ Emprego Formal } \\
\hline Sim & $1(3,2)$ & $2(2,8)$ & $1(1,0)$ & $4(2,0)$ \\
\hline Não & $30(96,8)$ & $69(97,2)$ & $98(99,0)$ & $197(98,0)$ \\
\hline \multicolumn{5}{|l|}{ Principal atividade econômica } \\
\hline Agricultura & $23(74,2)$ & $46(64,8)$ & $76(76,8)$ & $145(72,1)$ \\
\hline Pecuária & $1(3,2)$ & $3(4,2)$ & $21(21,2)$ & $25(12,4)$ \\
\hline Outras (turismo, artesanato, etc.) & $7(22,6)$ & $22(31,0)$ & $2(2,0)$ & $31(15,5)$ \\
\hline \multicolumn{5}{|l|}{ Renda mensal familiar ${ }^{(*)}$} \\
\hline Menor que um salário mínimo & $16(51,6)$ & $38(53,5)$ & $61(61,6)$ & $115(57,2)$ \\
\hline Entre 1 e 2 salários mínimos & $11(35,5)$ & $31(43,7)$ & $20(20,2)$ & $62(30,8)$ \\
\hline Entre 2 e 3 salários mínimos & $4(12,9)$ & - & $18(18,2)$ & $22(10,9)$ \\
\hline Entre 3 e 4 salários mínimos & - & $2(2,8)$ & - & $2(1,0)$ \\
\hline \multicolumn{5}{|l|}{ Recebimento de bolsa do governo } \\
\hline Sim & $11(35,5)$ & $53(74,6)$ & $63(63,6)$ & $127(63,2)$ \\
\hline Não & $20(64,5)$ & $18(25,4)$ & $36(36,4)$ & $74(36,8)$ \\
\hline
\end{tabular}

A adversidade frente à mobilidade se constitui em um dos principais problemas vivenciados pelos moradores da Comunidade Kalunga, que resulta em dificuldades na locomoção das pessoas e no transporte de mantimentos e outros produtos vindos da cidade $^{(215)}$. Os meios de deslocamento utilizados pelos moradores são a pé $(65,2 \% ; n=131)$ 
das referências, seguido pelo uso de animais $(n=38 ; 18,9 \%)$. Outros transportes, como bicicletas, carros e motos, também foram mencionados por 15,9\% (n=32) dos Kalungas entrevistados.

No que se refere ao perfil alimentar Kalunga, Vieira e Monteiro ${ }^{(58)}$ relatam a existência de um processo simbólico envolvendo a alimentação, desde sua produção até o consumo dos alimentos cultivados pelos moradores em suas próprias terras. As principais culturas agrícolas são: mandioca, milho, arroz de sequeiro, amendoim, gergelim, inhame, abóbora, maracujá e cana. A alimentação é enriquecida por frutos do cerrado coletados em grandes áreas que continuam preservadas. Observou-se, assim, que nas refeições costumam predominar o uso de alimentos cultivados $(\mathrm{n}=115 ; 57,2 \%)$ quando comparado com os alimentos industrializados ( $n=86 ; 42,8 \%$ ), com destaque para itens como o arroz, o feijão, a farinha, o milho e a abóbora.

A principal ocupação relatada foi o trabalho como lavrador, com 86 referências $(42,8 \%)$; seguida pelos afazeres de dona de casa $(n=61 ; 30,3 \%)$ e de estudante $(n=47 ; 23,4 \%)$. Por fim, sete moradores referiram outras atividades $(3,5 \%)$, sendo três $(1,5 \%)$ guias turísticos, dois $(1,0 \%)$ Agentes Comunitários de Saúde, um pedreiro $(0,5 \%)$ e um motorista $(0,5 \%)$. Apenas quatro (4,0\%) moradores possuíam emprego formal fixo, enquanto que os demais 197 $(98,7 \%)$ sobrevivem com a renda proveniente de atividades informais de trabalho.

Com referência às atividades econômicas desenvolvidas no território Kalunga, sabe-se que esta comunidade é reconhecida pelo Governo Federal como agricultores familiares, sendo o trabalho desenvolvido por meio de um sistema de produção que combina a prática da agricultura, pecuária, caça, pesca, extrativismo vegetal, produção de artesanato e o processamento mínimo de vegetais. Deste modo, a economia gerada depende principalmente do uso de recursos naturais e apenas uma pequena parte da produção agropecuária é comercializada, sendo a produção da farinha de mandioca um exemplo desse excedente utilizado na comercialização com os municípios mais próximos e no próprio quilombo ${ }^{(217)}$.

A maioria dos moradores contemplados no estudo dedica-se à agricultura familiar nos roçados da comunidade $(\mathrm{n}=145 ; 72,1 \%)$. A criação de gado também foi apontada como responsável pelo componente econômico em 12,4\% $(\mathrm{n}=25)$ das ocorrências. As outras atividades econômicas corresponderam a $15,5 \%(n=31)$ das respostas ao item. Destaca-se que Monte Alegre foi o município que apresentou maior proporção de referências à pecuária enquanto principal ramo da atividade econômica desenvolvida $(\mathrm{n}=21 ; 21,2 \%)$. 
Os benefícios provenientes de programas governamentais são importantes elementos na composição da renda familiar dos Kalungas. Assim, 63,2\% (n=127) dos moradores entrevistados referiram receber algum tipo de auxílio financeiro do governo para composição da renda familiar. Ou seja, os Kalungas, de um modo geral, sobrevivem do trabalho na roça, da criação de pequenos rebanhos, da pesca, da produção de artesanatos, acrescidas da renda mínima provinda de aposentadorias e de outras ajudas governamentais, como o "Bolsa Família”, por exemplo ${ }^{(58)}$.

A pobreza no Brasil apresenta-se com um forte componente regional e como um fenômeno marcadamente rural. O território Kalunga é descrito em dados do governo federal brasileiro como possuidor dos índices mais baixos de desenvolvimento humano do Estado de Goiás ${ }^{(218)} \mathrm{e}$, desta forma, os resultados retrataram tal quadro de agravante pobreza rural e exclusão social.

Entre os moradores entrevistados não houve referências de renda mensal superior a quatro salários mínimos, destacando-se que 88,0\% (n=177) percebem até dois salários mínimos mensais, dos quais a maioria $(\mathrm{n}=115 ; 57,2 \%)$ sobrevive com uma renda inferior a um salário mínimo por mês. Sobre o descrito, Marinho ${ }^{(186)}$ acrescenta que a pouca disponibilidade de recursos, tanto de renda quanto de acesso a produtos do mercado e serviços, é um ponto de fragilidade dessa comunidade, impactando, inclusive, para uma condição de cidadania não completa.

De tal modo, a partir do teste de associação do qui-quadrado, a caracterização dos principais aspectos socioeconômicos dos quilombolas Kalungas, segundo município de moradia, permite a identificação de diferenças com significado estatístico em relação às variáveis: meio de deslocamento na comunidade $(\mathrm{p} \leq 0,001)$, alimento predominante nas refeições $(p \leq 0,001)$, ocupação $(p \leq 0,001)$, emprego formal $(p \leq 0,001)$, principal atividade econômica $(\mathrm{p} \leq 0,001)$, renda mensal $(\mathrm{p} \leq 0,001)$ e recebimento de bolsa proveniente do governo $(\mathrm{p} \leq 0,001)$.

Na Tabela 4, são mostrados os dados globais acerca da caracterização dos domicílios nas Comunidades Kalungas. 


\begin{tabular}{|c|c|c|c|c|}
\hline \multirow[b]{2}{*}{ Variáveis } & \multicolumn{4}{|c|}{ Municípios } \\
\hline & $\begin{array}{c}\text { Cavalcante } \\
\mathrm{n}(\%)\end{array}$ & $\begin{array}{c}\text { Teresina de Goiás } \\
\mathrm{n}(\%)\end{array}$ & $\begin{array}{c}\text { Monte Alegre } \\
\mathrm{n}(\%) \\
\end{array}$ & $\begin{array}{l}\text { Total } \\
\mathrm{n}(\%)\end{array}$ \\
\hline \multicolumn{5}{|l|}{ Estrutura das paredes } \\
\hline Adobe & $22(71,0)$ & $54(76,0)$ & $78(78,8)$ & $154(76,6)$ \\
\hline Madeira & - & $2(2,8)$ & - & $2(1,0)$ \\
\hline Alvenaria & $9(29,0)$ & $14(19,7)$ & $19(19,2)$ & $42(20,9)$ \\
\hline Outras & - & $1(1,4)$ & $2(2,0)$ & $3(1,5)$ \\
\hline \multicolumn{5}{|l|}{ Piso interno } \\
\hline Terra batida & $8(25,8)$ & $16(22,5)$ & $59(59,6)$ & $83(41,3)$ \\
\hline Cimento & $22(71,0)$ & $54(76,1)$ & $40(40,4)$ & $116(57,7)$ \\
\hline Outros & $1(3,2)$ & $1(1,4)$ & - & $2(1,0)$ \\
\hline \multicolumn{5}{|l|}{ Telhado } \\
\hline Palha & $1(3,2)$ & $10(14,1)$ & $9(9,1)$ & $20(10,0)$ \\
\hline Telha de barro & $25(80,6)$ & $60(84,5)$ & $90(90,9)$ & $175(87,1)$ \\
\hline Outros & $5(16,1)$ & $1(1,4)$ & - & $6(3,0)$ \\
\hline \multicolumn{5}{|l|}{ Número de cômodos } \\
\hline Somente 1 cômodo & - & $1(1,4)$ & - & $1(0,5)$ \\
\hline Entre 2-3 cômodos & $2(6,5)$ & $7(9,9)$ & - & $9(4,5)$ \\
\hline Entre 4-5 cômodos & $24(77,4)$ & $62(87,3)$ & $73(73,7)$ & $159(79,1)$ \\
\hline Acima de 6 cômodos & $5(16,1)$ & $1(1,4)$ & $26(26,3)$ & $32(15,9)$ \\
\hline \multicolumn{5}{|l|}{ Peridomicílio (terra) } \\
\hline Sim & $31(100)$ & 71(100) & $99(100)$ & 201(100) \\
\hline Não & - & - & - & - \\
\hline \multicolumn{5}{|l|}{ Presença de energia elétrica } \\
\hline Sim & $31(100,0)$ & $66(93,0)$ & $99(100,0)$ & $196(97,5)$ \\
\hline Não & - & $5(7,0)$ & - & $5(2,5)$ \\
\hline \multicolumn{5}{|c|}{ Presença de água encanada no interior da casa } \\
\hline $\mathrm{Sim}$ & $14(45,2)$ & $29(40,9)$ & $22(22,2)$ & $65(32,3)$ \\
\hline Não & $17(54,8)$ & $42(59,1)$ & $77(77,8)$ & $136(67,7)$ \\
\hline \multicolumn{5}{|c|}{ Presença de banheiro no peridomicílio } \\
\hline Sim & $19(61,3)$ & $42(59,2)$ & $54(54,5)$ & $115(57,2)$ \\
\hline Não & $12(38,7)$ & $29(40,8)$ & $75(45,5)$ & $86(42,8)$ \\
\hline \multicolumn{5}{|c|}{ Presença de fossa séptica no domicílio } \\
\hline Sim & $17(54,8)$ & $23(32,4)$ & $9(9,1 \%)$ & $49(24,4)$ \\
\hline Não & $14(45,2)$ & $48(67,6)$ & $90(90,9)$ & $152(75,6)$ \\
\hline
\end{tabular}

Na comunidade estudada, os domicílios apresentam-se isolados e dispostos de modo que praticamente não formam aldeamentos ou arruamentos. Esta distribuição não linear das habitações e o distanciamento entre as casas são aspectos considerados elementos característicos da tipologia habitacional na localidade, conferindo certa "invisibilidade" em meio ao cerrado. Tal organização espacial pode ser entendida enquanto traço da estratégia social historicamente adotada pelas comunidades quilombolas, quer seja como produto da necessidade de não estar visível aos olhos dos bandeirantes e capitães do mato das minas de ouro de Goiás, quer seja como influência de sua ancestralidade africana ${ }^{(211,100)}$.

As edificações das casas Kalungas tanto apresentam tipologia tradicional como híbrida. Na primeira identifica-se o uso de técnicas assimiladas pela tradição e história oral, e 
desenvolvidas pela comunidade durante os séculos XVIII, XIX e XX, além dos materiais extraídos do próprio território, sendo o adobe o material de destaque. Identifica-se, assim, uma estrutura formada com tijolos de terra crua, água e palha e algumas vezes outras fibras naturais, moldados em fôrmas por processo artesanal. Já a tipologia híbrida é aquela em que a casa é construída mesclando-se técnicas tradicionais com as mais recentes como materiais pré-fabricados e comuns na construção civil atual. Esta é, quase sempre, resultado de reforma, incluindo as promovidas por programas de governo $^{(211)}$.

Assim, na descrição dos domicílios, foi observado que o adobe caracteriza-se enquanto tipo de material predominantemente empregado para a estruturação das casas $(\mathrm{n}=154 ; 76,6 \%)$. As construções de alvenaria correspondem a 20,9\% $(\mathrm{n}=42)$ do total estudado, sendo que no município de Cavalcante, especificamente, este percentual sobre para 29,0\% $(n=9)$.

O cimento aparece como principal piso interno da moradia Kalunga ( $\mathrm{n}=116 ; 57,7 \%)$, seguida pela terra batida $(n=83 ; 41,3 \%)$ e, por fim, por outros tipos de revestimento interno $(\mathrm{n}=2 ; 1,0 \%)$. O município de Teresina de Goiás foi o que apresentou a maior proporção de casas com o piso interno caracterizado pelo cimento queimado, ao passo que em Monte Alegre mais da metade dos moradores $(n=59)$ residem em moradias com chão de terra batida.

Com relação ao espaço peridomiciliar, este foi caracterizado em $100 \%$ dos casos $(\mathrm{n}=201)$ com a presença de chão batido. Ou seja, na área externa e ao redor das casas Kalungas há a presença da terra anteriormente recoberta pela vegetação do cerrado.

O principal material utilizado no telhado das casas foi a telha de barro $(\mathrm{n}=175 ; 87,1)$, a palha do buriti $(n=20 ; 10,0 \%)$ e, por último, os outros tipos de cobertura $(n=6 ; 3,0 \%)$. Nos três municípios, há certa semelhança com relação à distribuição proporcional das referências sobre o material empregado para a cobertura das moradias estudadas, sendo mais de $80,0 \%$ das respostas apontando o uso da telha de barro.

As 63 famílias residem em moradias que apresentam em média cinco cômodos. A proporção dos domicílios, de acordo com o número de divisões internas, demonstrou que a maioria das casas kalungas tem entre quatro e cinco cômodos $(n=159 ; 79,1 \%)$. As casas com mais de seis cômodos foram referidas por $15,9 \%(n=32)$ da amostra e as com dois ou três, por 4,5\% (n=9). Apenas $0,5 \%(n=1)$ dos sujeitos descreveu sua residência como possuidora de apenas um único compartimento. Estes números são compatíveis com os resultados nacionais 
e se aproximam dos achados de estudo sobre a implantação de infraestrutura habitacional em comunidades tradicionais realizado em 2006, o qual descreve que na Comunidade Quilombola Kalunga o número médio de cômodos por domicílio é 4,3, sendo 4,6 em Cavalcante, 4,3 em Monte Alegre e 4,1 3m Teresina de Goiás ${ }^{(211)}$.

O Programa Luz para Todos (PLpT), sob responsabilidade do Ministério de Minas e Energia, foi estabelecido em novembro de 2003, por meio da Lei n. ${ }^{\circ} 10.762$ e do Decreto n. ${ }^{\circ}$ 4.873, chegado à área do Sítio Histórico e Patrimônio Cultural Kalunga no ano de 2004. Contudo, como descrito pelos participantes do estudo, o programa não contemplou todos os moradores e comunidades ${ }^{(219)}$. Assim, a rede elétrica foi mencionada como tipo de iluminação por $97,5 \%(\mathrm{n}=196)$ dos respondentes. Todos os moradores que mencionaram o não abastecimento de suas residências por serviço de eletrificação $(n=5 ; 2,5 \%)$ residiam no município de Teresina de Goiás.

No estudo, verificou-se que todos $(\mathrm{n}=201 ; 100 \%)$ os moradores informaram não dispor dos serviços de uma rede pública de abastecimento de água. Conforme detalhamento proposto no Figura 5, pouco mais da metade dos moradores $(n=108 ; 53,7 \%)$ consomem água obtida por meio de mangueiras e da gravidade para a canalização de água para o domicílio, outros moradores $(n=60 ; 29,9 \%)$ recorrem à utilização de poços a partir das nascentes dos rios para a captação de água, dos quais 24,9\% (n=50) contam com bombas d’água para aperfeiçoar o processo, e 5,0\% $(\mathrm{n}=10)$ não dispõem deste recurso. A captação direta da água nos rios com galões ou baldes foi descrita por 33 indivíduos $(16,4 \%)$, sendo comum, nos lugarejos mais isolados e distantes dos rios e nascentes, que os moradores caminhem vários quilômetros para buscar água para as atividades do dia a dia, como cozinhar e beber, e também para fornecer aos animais ${ }^{(111)}$.

No município de Cavalcante, 61,3\% $(\mathrm{n}=19)$ dos moradores informaram que a água proveniente dos rios chega às residências com a utilização de mangueiras, enquanto os outros $38,7 \%(\mathrm{n}=12)$ referiram a busca de água diretamente na beira do leito dos rios com galões e baldes. No município de Teresina de Goiás não houve referências ao uso da gravidade para a canalização da água até a residência; contudo, esta região foi à única que mencionou o uso dos poços para a captação da água. Assim, 70,4\% (n=50) utilizam poços com bomba, 14,1\% $(\mathrm{n}=10)$ utilizam poços sem bomba e $15,5 \%(\mathrm{n}=11)$ realizam busca ativa da água. Por último, com relação ao município de Monte Alegre, pode-se afirmar que os moradores têm a água 
disponibilizada por meio de utilização de mangueiras e da gravidade ( $\mathrm{n}=89 ; 89,9 \%)$ ou, então, captam este recurso natural diretamente nos rios locais $(\mathrm{n}=10 ; 10,1 \%)$.

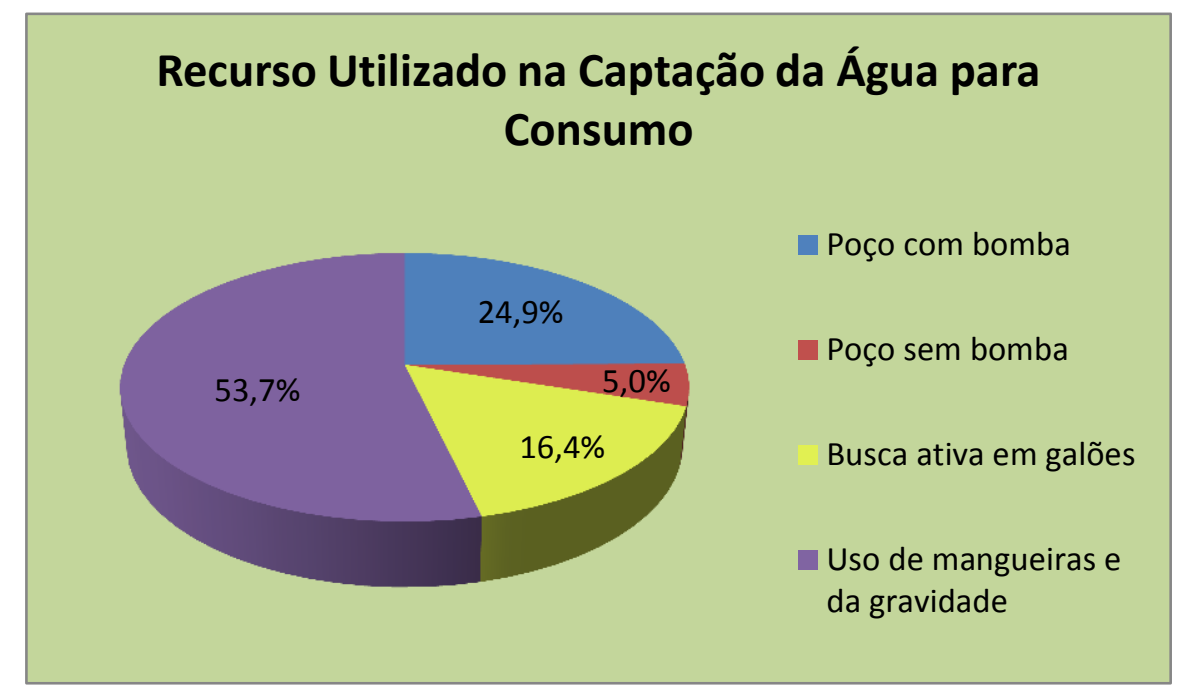

Figura 5 - Recurso utilizado na captação da água para consumo geral

$\mathrm{Na}$ Comunidade Kalunga, 67,7\% ( $\mathrm{n}=136)$ dos moradores estudados não têm água canalizada no interior da casa, sendo que por município esta proporção corresponde a 59,1\% $(n=17)$ em Cavalcante, 59,1\% ( $n=42)$ em Teresina de Goiás e 77,8\% ( $n=77)$ em Monte Alegre. Estes resultados podem sugerir um relativo aumento na proporção de moradores Kalungas que possuem água encanada no interior de suas residências quando comparados aos dados disponibilizados realizado, no ano de 2004, pela Fundação Universitária de Brasília no Levantamento socioeconômico e cultural das comunidades quilombolas de Alcântara (MA), Ivaporunduva (SP) e Kalunga (GO), com a coordenação da SEPPIR - Secretaria Especial de Políticas de Promoção da Igualdade Racial ${ }^{(109)}$.

No referido levantamento foi identificado que apenas 5,0\% dos moradores Kalungas entrevistados dispunham de água canalizada no interior de suas moradias, sendo que do percentual de moradores sem água encanada no interior do domicílio (95,0\%), 20,9\% dispunham de água canalizada fora de casa (no terreno) e 74,1\% não dispunham de água canalizada, captando a água para uso doméstico diretamente nos rios da região.

O abastecimento de água é um problema observado em outras áreas de remanescentes de quilombos, como nas comunidades Caiana dos Crioulos, na qual nenhum dos domicílios possui abastecimento por água encanada ${ }^{(90)}$ e Boqueirão, na qual o percentual de residências que não esse tipo de abastecimento é de $88,0 \%{ }^{(220)}$. 
Os resultados do presente estudo demonstraram que nem todos os moradores dispunham de banheiro em casa $(n=86 ; 42,8 \%)$ e $57,2 \% \quad(n=115)$ responderam afirmativamente apenas quando questionados sobre a presença de banheiro no espaço peridomiciliar das casas. O município de Cavalcante foi o que apresentou o menor percentual de participantes que referiram ausência de banheiro nos domicílios $(n=12 ; 38,7 \%)$, seguido por Teresina de Goiás $(n=29 ; 40,8 \%)$ e por Monte Alegre $(n=45 ; 45,5 \%)$.

Sobre a presença de banheiro no domicílio, foram identificados indícios de uma possível redução de percentual nas referências às casas sem banheiro, uma vez que em levantamento realizado no ano de 2004, a proporção encontrada para residências sem banheiro com chuveiro e privada foi de $94,3 \%{ }^{(109)}$. Realidade que pode ser fruto de recentes ações para a implantação de infraestrutura habitacional no território do Sítio Histórico, com vistas à garantia do acesso a direitos sociais e econômicos aos remanescentes quilombolas Kalungas.

No estudo não houve nenhuma referência ao despejo do esgoto sanitário em rede pública coletora. O esgotamento sanitário é, em geral, feito por meio de fossas rudimentares ou é lançado no terreno, o qual se constitui em um risco para os poços e córregos. A utilização de fossa séptica no domicílio ocorreu 24,4\% (n=49) dos casos; os demais utilizavam fossa negra $(n=12 ; 54,2 \%)$ ou jogavam o esgoto a céu aberto $(n=43 ; 21,4 \%)$, conforme demonstrado na Figura 6. Assim, entre os moradores e em se tratando do não uso da fossa séptica, Monte Alegre é o município responsável por 59,2\%(n=90) da destinação ambiental direta dos dejetos humanos, seguida por Teresina de Goiás $(n=48 ; 31,6 \%)$ e por Cavalcante com uma participação de $9,2 \%(n=14)$.

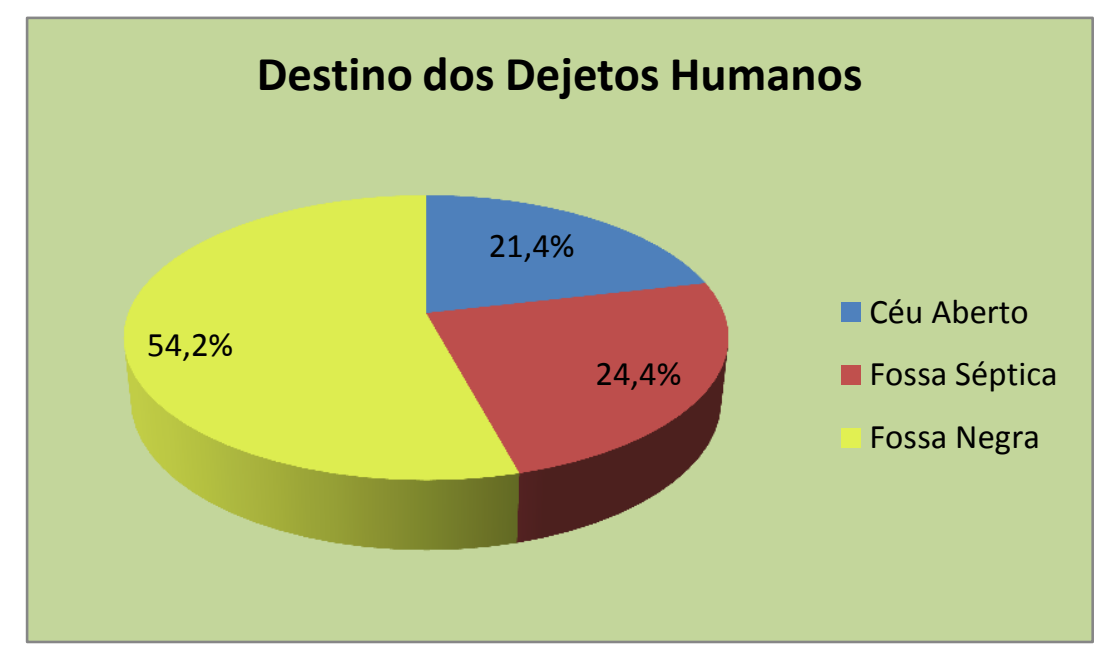

Figura 6 - Destinação dos dejetos humanos no domicílio 
Conforme a Tabela 4, pode-se afirmar que houve significado estatístico na associação entre a variável município de Residência e as variáveis estrutura das paredes $(\mathrm{p} \leq 0,001)$; Piso Interno ( $\mathrm{p} \leq 0,001)$; Descrição do Telhado ( $\mathrm{p} \leq 0,001)$; Tipo de Iluminação $(\mathrm{p} \leq 0,009)$; Presença de Banheiro no Peridomicílio ( $\mathrm{p} \leq 0,001)$; e presença de fossa séptica no domicílio $(\mathrm{p} \leq 0,001)$. Nas análises foi utilizado o teste qui-quadrado.

Assim, com relação às condições de habitação dos domicílios Kalungas no que se refere ao abastecimento de água, esgotamento sanitário, destino do lixo e existência de eletricidade, pode-se evidenciar que a realidade vivenciada ainda se apresenta muito longe do ideal $^{(211)}$.

Estas comunidades afrodescendentes, mesmo com uma maior atenção recebida nos últimos anos por parte das entidades governamentais e sociedade civil, na tentativa de contribuir com a superação tanto da exclusão social quanto da pobreza extrema, ainda vivem em condições de vulnerabilidade, principalmente no que tange à questão sanitária, uma vez que o abastecimento de água e energia, o tratamento de esgoto, a coleta de lixo e o manejo dos resíduos são tidos como um dos principais pontos críticos para a comunidade ${ }^{(58)}$.

A posse de bens duráveis de consumo pode ser considerada um mecanismo de estimativa indireta de aspectos econômicos e sociais correlatos ao padrão de renda e de bemestar de uma população ${ }^{(221)}$. Desta forma, a dificuldade no acesso aos bens duráveis representa um entre os vários problemas que demandam atenção em se tratando da questão quilombola no Brasil ${ }^{(58)}$.

Entre os moradores Kalungas observa-se que o rádio, a televisão, a geladeira e o fogão a gás foram os bens duráveis mais encontrados nas residências da comunidade, podendo ser identificados em 87,5\% (n=175) das citações. A antena parabólica, responsável pela captação do sinal de TV, também se destacou entre as citações, sendo mencionado em 55,2\% ( $\mathrm{n}=110)$ das ocorrências. Por outro lado, pode-se destacar que 3,5\% $(n=7)$ dos moradores entrevistados referiu não possuir nenhum bem durável. Estes achados estão de acordo com o encontrado em estudos anteriores, realizados nos anos de 2004 e 2009, que destacaram o fogão a gás e o rádio enquanto bens duráveis mais encontrados nas residências do Sítio Histórico e Patrimônio Cultural Kalunga ${ }^{(101,109)}$.

Em relação ao acesso aos meios de comunicação, 85,1\% (n=170) dos moradores da Comunidade Kalunga afirmam que escutam rádio, assistem a televisão, mas não têm acesso a 
jornais ou revistas escritos, seguido quilombolas que escutam rádio de pilha, mas não têm acesso à televisão, jornais e revistas $(n=7 ; 3,5 \%)$. Apenas 4,0\% $(n=8)$ dos moradores respondentes referiram ter acesso aos meios de comunicação escritos, como jornais e revista.

A internet é acessada por 1,0\% $(\mathrm{n}=2)$ da população do estudo. Os dados revelam ainda que 7,5\% (n=15) não usam nenhum tipo de meio de comunicação na comunidade, podendo indicar a situação de relativo isolamento da população Kalunga em relação ao que acontece fora da comunidade.

Neiva ${ }^{(101)}$, em seu estudo, aponta o rádio a pilha como a principal fonte de informação dos Kalungas e associa este achado ao fato da maior parte da comunidade não ter acesso a energia elétrica, explicando a ausência de outros tipos de bens duráveis. Assim, pode-se sugerir a inserção, além do rádio a pilha, de outros meios de comunicação, principalmente a televisão no cotidiano da comunidade, tendo como hipótese justificativa a ampliação no acesso à energia elétrica.

\subsection{CARACTERIZAÇÃO DO PERFIL PARASITOLÓGICO}

A caracterização do perfil epidemiológico de uma comunidade tem como objetivo conhecer aspectos inerentes à real conjuntura de saúde em uma localidade. Frente à situação de precariedade, ou até mesmo total ausência de infraestrutura sanitária vivenciada pela população Kalunga ${ }^{(58)}$, evidencia-se a relevância do enfoque nos agravos em saúde influenciados por tal condição.

A ocorrência de parasitoses intestinais pode ser citada como um exemplo de problema de saúde intimamente relacionada à condição sociossanitária de indivíduos e populações ${ }^{(158)}$. Assim, o estabelecimento de associações entre o perfil parasitológico de uma comunidade e suas condições de saúde, incluindo os aspectos sanitários, pode ser considerado um valioso instrumento no direcionamento de recursos e ações para a promoção da saúde e melhoria da qualidade de vida dos grupos populacionais.

Nesta etapa do estudo foram avaliados alguns parâmetros epidemiológicos das principais enteroparasitoses identificadas entre moradores dos três municípios estudados. Para a consecução da análise e discussão dos resultados, foi considerado o quantitativo 153 indivíduos que responderam a ficha de investigação epidemiológica e realizaram exames parasitológicos de fezes. 
Os enteroparasitos têm uma extensa distribuição geográfica, afetando com maior intensidade países em desenvolvimento ${ }^{(222)}$. No Brasil, a prevalência de parasitoses é considerada alta, principalmente entre populações de baixo nível socioeconômico ${ }^{(223)}$, como no caso dos Kalungas que vivem em uma região marcada pela falta de investimentos em infraestrutura, carente de políticas básicas de saúde, educação e assistência social, o que agrava ainda mais as condições de saúde dessa população.

Assim, os resultados evidenciaram infestação por enteroparasitas nos moradores dos três municípios estudados. A prevalência de parasitoses intestinais na comunidade quilombola Kalunga foi de 15,7\% ( $\mathrm{n}=24)$. De modo geral, as infestações parasitárias podem ser classificadas em dois grupos: patogênicos e não patogênicos, ambas denotando, de alguma forma, a transmissão pela água ou alimento contaminado. No primeiro grupo encontram-se a Entamoeba histolytica e os ancilostomídeos, e no segundo grupo estão Entamoeba coli, Endolimax nana e Iodamoeba butshilii.

No estudo, as protozooses foram mais frequentes $(n=22 ; 92,3 \%)$ que as helmintíases $(n=2 ; 7,7 \%)$. Achados semelhantes foram verificados, em 2013, na comunidade quilombola Boqueirão, localizada no município de Vitória da Conquista, região sudoeste do Estado da Bahia, na qual as protozoozes $(32,7 \%)$ também foram descritas mais frequentes que as helmintoses, com proporções de $32,7 \%$ e $5,4 \%$, respectivamente ${ }^{(220)}$.

As prevalências encontradas para protozoários foram: cistos de Entamoeba coli (n=8; 38,5\%), cistos de Endolimax nana (n=7; 33,5\%), cistos de Iodomoeba butshilli (n=4; 19,5\%) e cistos de Entamoeba histolytica $(\mathrm{n}=3 ; 11,5 \%)$. Para helmintos intestinais, identificou-se a presença de ovos de ancilostomídeos $(n=2 ; 100 \%)$.

No que se refere à distribuição dos resultados positivos dos exames parasitológicos por microrganismo e município de estudo, pôde-se inferir que o município de Cavalcante apresentou $8 \%(\mathrm{n}=2)$ dos casos, todos em relação a cistos de Iodomoeba butshilii. Teresina de Goiás foi responsável por $56,0 \%(\mathrm{n}=14)$ do total de exames positivos, dos quais $12,0 \%(\mathrm{n}=3)$ para monoparasitismo por Iodomoeba butshilii; 24,0\% (n=6) para Entamoeba coli; 4,0\% $(\mathrm{n}=1)$ para Entamoeba histolytica; 8,0\% (n=2) Endolimax nana; 4,0\% (n=1) para ovos de ancilostomídeos, e, também, 4,0\% (n=1) para poli parasitismo tanto por Iodomoeba butshilii quanto por Entamoeba histolytica. Já no município de Monte Alegre de Goiás constataram-se $36,0 \%(n=10)$ dos casos de infestação. Destes, 10,0\% $(n=1)$ foram positivos para 
monoparasitismo por Iodomoeba butshilii; 40,0\% (n=4) para Entamoeba coli; 20,0\% (n=2) para Entamoeba histolytica; 20,0\% (n=2) Endolimax nana; e, 10,0\% (n=1) para ovos de ancilostomídeos.

De maneira geral, considerando os resultados dos três municípios, pode-se inferir que a espécie com maior incidência foi Entamoeba coli, tendo sido encontrada em 40,0\% (n=10) dos exames positivos. Os outros parasitas encontrados foram a Endolimax nana $(n=6 ; 24,0 \%)$; Iodomoeba butshilii ( $\mathrm{n}=5,20,0 \%) ;$ Entamoeba histolytica $(\mathrm{n}=3 ; 12,0 \%)$; e, Ovos de ancilostomídeos $(\mathrm{n}=2 ; 8,0 \%)$.

Os protozoários intestinais não patógenos costumam ser mais prevalentes que os patogênicos. Contudo, estes protozoários enterocomensais possuem os mesmos mecanismos de transmissão fecal-oral de outros enteroparasitos patogênicos, constituindo-se em indicador útil da relação entre as condições sociais e sanitárias ${ }^{(220)}$.

De tal maneira, a importância da identificação deste grupo de parasitos não patogênicos reside na constatação de contaminação, em especial da água utilizada para consumo humano. Sua principal indicação de diagnóstico ultrapassa o caráter curativo, reforçando a importância da necessidade de investimentos nas ações profiláticas de promoção à saúde. A existência de protozoários intestinais não patogênicos, por si só, demonstra a existência de contaminação ambiental por dejetos fecais, o que é plausível de entendimento a se considerar as precárias condições sanitárias da Comunidade Kalunga ${ }^{(224)}$

As parasitoses intestinais são demandas em saúde de estreita relação com o contexto socioeconômico e higiênico sanitário de uma população. As condições de vida, moradia e saneamento básico são, em grande parte, determinantes da transmissão de muitos parasitos. Além disto, deve-se mencionar que os principais fatores de risco associados à ocorrência de enteroparasitoses são as precárias condições sanitárias, educacionais, sociais e econômicas; tratamento insuficiente da água; elevado índice de aglomeração de pessoas; uso inadequado do solo e contaminação deste e dos alimentos ${ }^{(152)}$.

Os resultados sugerem, assim, que a ocorrência de enteroparasitoses emerge enquanto agravo capaz de ilustrar a interface entre condicionantes sociais e saúde, exprimindo a vulnerabilidade da população Kalunga, uma vez que as enteroparasitoses, comensais ou patológicas, constituem-se em importante indicador de precariedade nas condições de higiene e saneamento das populações ${ }^{(22)}$. 
Na Tabela 5, são mostrados os diferentes tipos de infestações por enteroparasitas entre os quilombolas Kalungas do estudo. Na distribuição proporcional foram consideradas as variáveis: município de localização da comunidade, sexo, faixa etária, grau de escolaridade, ocorrência de episódio diarreico no último mês, presença de coliformes termotolerantes na água que abastece a casa e hábito individual de lavagem das mãos após eliminações fisiológicas.

Tabela 5 - Distribuição de infestação segundo município, sexo, faixa etária e grau de escolaridade no Sítio Histórico e Patrimônio Cultural Kalunga, em 2012

\begin{tabular}{|c|c|c|}
\hline \multirow[b]{2}{*}{ Variáveis } & \multicolumn{2}{|c|}{ Infestação } \\
\hline & $\begin{array}{c}\mathrm{Sim} \\
\mathrm{n}(\%)\end{array}$ & $\begin{array}{l}\text { Não } \\
\text { n(\%) }\end{array}$ \\
\hline \multicolumn{3}{|l|}{ Município } \\
\hline Cavalcante & $2(13,3)$ & $13(86,7)$ \\
\hline Teresina de Goiás & $13(26,0)$ & $37(74,0)$ \\
\hline Monte Alegre de Goiás & $9(10,2)$ & $79(89,8)$ \\
\hline \multicolumn{3}{|l|}{ Sexo } \\
\hline Masculino & $10(15,6)$ & $54(84,4)$ \\
\hline Feminino & $14(15,7)$ & $75(84,3)$ \\
\hline \multicolumn{3}{|l|}{ Faixa Etária } \\
\hline Menor de 18 anos & $13(16,3)$ & $67(83,8)$ \\
\hline Entre $18-50$ anos & $7(13,7)$ & $44(86,3)$ \\
\hline 51 anos ou mais & $4(18,2)$ & $18(81,8)$ \\
\hline \multicolumn{3}{|l|}{ Grau de Escolaridade } \\
\hline Alfabetizado & $13(17,3)$ & $62(82,9)$ \\
\hline Não alfabetizado & $11(14,1)$ & $67(85,9)$ \\
\hline \multicolumn{3}{|l|}{ Episódio Diarreico no último mês } \\
\hline Sim & $14(14,1)$ & $85(85,9)$ \\
\hline Não & $10(18,5)$ & $44(81,5)$ \\
\hline \multicolumn{3}{|l|}{ Coliformes termotolerantes na água } \\
\hline Sim & $9(10,2)$ & $79(89,8)$ \\
\hline Não & $15(23,1)$ & $50(76,9)$ \\
\hline \multicolumn{3}{|l|}{ Sempre lava as mãos após ir ao banheiro? } \\
\hline Sim & $2(3,5)$ & $55(96,5)$ \\
\hline Não & $22(22,9)$ & $74(77,1)$ \\
\hline
\end{tabular}

Do total de pessoas examinadas, identificou-se 24 (15,7\%) moradores com pelo menos uma espécie diferente de parasito. Na distribuição percentual da amostra por presença de infestação, segundo município, sexo, grupo de idade e nível de escolaridade, observou-se que $13,3 \%(\mathrm{n}=2)$ dos moradores entrevistados de Cavalcante apresentaram resultado positivo para a presença de pelo menos uma espécie de parasito intestinal, independentemente da relação de patogenicidade ou não. Nos municípios de Teresina de Goiás e Monte Alegre estas proporções foram de $26,0 \%(n=13)$ e $10,2 \%(n=9)$, respectivamente.

O sexo não se configurou em uma variável determinante na definição de infestação parasitária, já que as proporções de distribuição entre homens $(n=10 ; 15,6 \%)$ e mulheres 
( $\mathrm{n}=14 ; 15,7 \%)$ apresentaram-se similares. O mesmo padrão de não determinação na definição de infestação parasitária ocorreu em relação à faixa etária, variável na qual predominou nos extremos as maiores proporções de positividade: menores de 18 anos $(n=13 ; 16,3 \%)$ e maiores de 51 anos $(n=4 ; 18,2 \%)$.

A partir da variável grau de escolaridade foi possível inferir que 14,1\% (n=11) dos moradores Kalungas 'não alfabetizados' também estavam infestados por algum tipo de parasito intestinal, e que, dentre os Kalungas alfabetizados, este percentual foi de 17,3\% $(n=13)$.

Assim, pode-se constatar que a variável presença de infestação por parasito intestinal apresentou um padrão similar em sua distribuição percentual no que diz respeito a município de moradia, sexo, grupo de idade e nível de escolaridade. Uma possível explicação para a esta similitude na distribuição dos dados é o fato de que na comunidade Kalunga, os moradores têm seu espaço habitacional distribuído em povoados. E estes, por sua vez, apresentam condições semelhantes de moradia, renda familiar, presença de animais e a não existência de saneamento. Pode-se acrescentar a esta realidade a perspectiva de que a variável município, que trata da caracterização destes grupamentos de moradias, é estatisticamente significativa, $\mathrm{p}=0,048$, segundo teste do qui-quadrado.

Dentre o grupo de pessoas que tiveram seu exame parasitológico positivo, 14,1\% $(\mathrm{n}=14)$ apresentaram pelo menos um episódio diarreico no último mês. A literatura estima que a diarreia tenha $88 \%$ de sua carga de ocorrência atribuída ao abastecimento de água, esgotamento sanitário e higiene inadequados ${ }^{(226)}$. Assim, a conjuntura de fragilidade nas condições de vida da população Kalunga (acesso ineficaz, a renda, escolaridade, habitação, disponibilidade de água encanada e rede de esgoto) acaba contribuindo para a ocorrência de episódios diarreicos.

Essas condições não são responsáveis diretas pela ocorrência do agravo diarreico; contudo, por meio de efeitos de ação e reação, acabam por favorecer a proximidade de seus determinantes $^{(148)}$. Ademais, o evento diarreico também pode relacionar-se à ação do próprio parasito, uma vez que a diarreia pode ser citada como um dos danos que os enteroparasitas causam a seus portadores, sendo as manifestações clínicas usualmente proporcionais à carga parasitária albergada pelo indivíduo ${ }^{(161)}$. 
A análise microbiológica da água utilizada pela Comunidade Kalunga indicou a presença de coliformes termotolerantes em 42,5\% ( $n=28)$ das amostras coletadas, sendo esta positividade, quanto à análise das amostras, indicador da contaminação da fonte de água por microrganismos de origem entérica e sugerindo certa fragilidade com relação qualidade da água utilizada pela comunidade Kalunga. A Portaria n. ${ }^{\circ}$ 518/2004, do Ministério da Saúde, determina padrões de qualidade de água para consumo humano, estabelecendo como critério a ausência de coliformes termotolerantes, desse modo condenando, sob aspectos sanitários, as fontes de águas positivas para a presença destes microrganismos ${ }^{(227)}$.

A água utilizada em todos os domicílios é obtida diretamente dos rios da região, a comunidade não dispõe de um sistema público de tratamento e distribuição de água. Quase a metade da população Kalunga entrevistada refere não realizar nenhum tipo de tratamento na água utilizada para consumo humano antes de beber. Deste modo, sem nenhum tipo de tratamento com a água, antes de sua chegada ao domicílio e também neste, potencializa-se um grave problema já que a água não tratada pode ser uma fonte de transmissão de inúmeras doenças de veiculação hídrica, tal como as enteroparasitoses ${ }^{(228)}$.

Além do mais, foi possível constatar que na comunidade nem todos os moradores entrevistados dispõem de banheiro com fossa séptica, sendo os dejetos humanos, predominantemente, eliminados no leito de rios, no solo nas proximidades do local de residência ou, ainda, em fossas negras.

Assim, a identificação, por meio de análise microbiológica, da presença de algum grau de coliformes termotolerantes nas águas que abastecem parte das residências Kalungas reforça a hipótese de que os efluentes dos dejetos produzidos, seja de origem humana ou animal, podem, ao percolar pelo solo, atingir as fontes de água para consumo da população ${ }^{(228)}$.

Destaca-se que a variável presença de coliformes termotolerantes apresentou significância estatística quando em associação com a variável presença de infestação por enteropatógenos $(\mathrm{p}=0,031)$. Sobre isto, foi demonstrado que $10,2 \%(\mathrm{n}=9)$ dos moradores que tiveram seus exames parasitológicos positivos tinham suas residências abastecidas por fonte de água também cujo resultado detectou a presença de coliformes termotolerantes.

No presente estudo, foi observada uma estreita relação entre hábitos de higiene e ocorrência;a de infestação por parasitos intestinais, evidenciada na forte associação (teste quiquadrado: $\mathrm{p}=0,001$ ) entre a variável lavagem das mãos com a ocorrência de infestação por 
enteropatógenos. Cabral-Miranda, Dattoli e Dias-Lima, em estudo sobre as condições socioeconômicas e sanitárias em uma comunidade quilombola localizada no distrito de Tijuaçú, Senhor do Bonfim, no semiárido baiano, destacam a relação direta existente entre as condições de higiene pessoal com as altas taxas de prevalência das infestações parasitárias, sejam elas de origem patogênica ou não ${ }^{(222)}$.

Ademais, tal concepção é corroborada na indicação de que a falta ou inobservância de princípios de higiene pessoais da lavagem das mãos é um importante fator que predispõe as pessoas à infecção por enteroparasitas, uma vez que as mãos muitas vezes servem de veículo de contaminação fecal-oral ${ }^{(161)}$. Entre os moradores com exame parasitológico positivo, 91,7\% (n=22) referiram não lavar as mãos regularmente após a utilização do banheiro ou equivalente no atendimento de suas necessidades fisiológicas. Por outro lado, apenas 3,5\% $(n=2)$ dos que lavam as mãos com regularidade apresentaram positividade para no exame parasitológico.

$\mathrm{Na}$ Tabela 6, estão descritos os achados referentes à distribuição proporcional da amostra por ocorrência de diarreia no último mês e segundo as variáveis: presença de infestação, grau de escolaridade, tipo de patógeno, presença de água encanada dentro de casa, existência de banheiro em casa, realização de tratamento na água de beber, presença de coliformes termotolerantes na água destinada ao consumo humano e realização de lavagem das mãos após utilização do banheiro ou equivalente. 
Tabela 6-Distribuição de casos de diarreia no último mês, segundo, condições sanitárias dos domicílios e infestações por diferentes espécies de parasitos no Sítio Histórico e Patrimônio Cultural Kalunga, em 2012

\begin{tabular}{|c|c|c|}
\hline \multirow[b]{2}{*}{ Características } & \multicolumn{2}{|c|}{ Episódio diarreico no último mês } \\
\hline & $\begin{array}{c}\mathrm{Sim} \\
\mathrm{n}(\%)\end{array}$ & $\begin{array}{l}\text { Não } \\
\text { n(\%) }\end{array}$ \\
\hline \multicolumn{3}{|l|}{ Infestação } \\
\hline $\mathrm{Sim}^{3}$ & $14(58,3)$ & $10(41,7)$ \\
\hline Não & $85(65,9)$ & $44(34,1)$ \\
\hline \multicolumn{3}{|l|}{ Grau de Escolaridade } \\
\hline Não Alfabetizado & $52(66,7)$ & $26(33,3)$ \\
\hline Alfabetizado & $47(62,7)$ & $28(37,3)$ \\
\hline \multicolumn{3}{|l|}{ Tipo de Parasito } \\
\hline Cistos de Endolimax nana & $1(33,3)$ & $2(66,7)$ \\
\hline Cistos de Iodomoeba butshilii & $6(60,0)$ & $4(40,0)$ \\
\hline Cistos de Entamoeba coli & $3(100,0)$ & - \\
\hline Cistos de Entamoeba histolytica & $3(50,0)$ & $3(50,0)$ \\
\hline Ovos de ancilostomídeos & $2(100,0)$ & - \\
\hline Entamoeba histolytica+Ovos de ancilostomídeos & - & $1(100,0)$ \\
\hline \multicolumn{3}{|l|}{ Água encanada dentro de casa } \\
\hline Sim & $64(73,6)$ & $23(26,4)$ \\
\hline Não & $35(53,0)$ & $31(47,0)$ \\
\hline \multicolumn{3}{|l|}{ Presença de banheiro dentro de casa } \\
\hline Sim & $66(66,7)$ & $33(33,3)$ \\
\hline Não & $33(61,1)$ & $21(38,9)$ \\
\hline \multicolumn{3}{|l|}{ Água com presença de coliformes termotolerantes } \\
\hline Sim & $63(71,6)$ & $25(28,4)$ \\
\hline Não & $36(55,4)$ & $29(44,6)$ \\
\hline \multicolumn{3}{|l|}{ Tratamento com a água de beber } \\
\hline Sim & $36(46,8)$ & $41(53,2)$ \\
\hline Não & $63(82,9)$ & $13(17,1)$ \\
\hline \multicolumn{3}{|l|}{ Sempre lava as mãos após ir ao banheiro? } \\
\hline Sim & $41(71,9)$ & $16(28,1)$ \\
\hline Não & $58(60,4)$ & $38(39,6)$ \\
\hline
\end{tabular}

Como mencionado anteriormente, a ocorrência de casos de diarreia foi um achado relevante no estudo, pois apenas 35,3\% $(\mathrm{n}=54)$ dos indivíduos responderam negativamente quando questionados a este respeito. Assim, a partir da Tabela 7, verifica-se que dentre o total de indivíduos com exames parasitológicos positivos $(n=24), 58,3 \% \quad(n=14)$ mencionam episódios diarreicos no último mês. Já entre os sujeitos não infestados por enteroparasitas $(n=129)$, a presença de episódios diarreicos no último mês foi referida por 65,9\% ( $\mathrm{n}=85)$ dos casos. Ademais, partindo-se do total de pessoas que referenciaram episódio diarreico no último mês ( $\mathrm{n}=99), 14,1 \%(\mathrm{n}=14)$ tiveram resultados positivos para a presença de parasitos no exame de fezes.

A variável grau de escolaridade nos permite constatar que não houve diferenças significativas entre o grupo de alfabetizados e não alfabetizados em relação à ocorrência de episódio diarreico no último mês. Isto porque, entre os 'não alfabetizados', 66,7\% (n=55) 
referiram ter apresentado episódio diarreico no último mês, similarmente ao grupo de alfabetizados, onde $62,7 \%(n=47)$ apresentaram a mesma resposta.

Com relação à associação entre as variáveis, tipo de parasito e episódio diarreico no último mês, pode-se constatar que as proporções da tabela de referência cruzada foram distribuídas da seguinte maneira: 33,3\% (n=1) dos Kalungas infestados por cistos de Endolimax nana referiram diarreia no último mês; 60,0\% $(\mathrm{n}=6)$ dos infestados por Cistos de Iodomoeba butshilii; 100,0\% ( $\mathrm{n}=3)$ dos infestados por cistos de Entamoeba coli; 50,0\% (n=3) dos infestados por cistos de Entamoeba histolytica; e, finalmente, 100,0\% (n=2) dos Kalungas infestados por Entamoeba histolytica e por ovos de ancilostomídeos também referiram diarreia no último mês. Sobre o exposto, destaca-se que os mecanismos pelos quais os parasitos intestinais produzem diarreia são diversos, sendo a magnitude e o significado funcional da resposta diarreica, geralmente, proporcional ao número de vermes e espécie ${ }^{(54)}$.

Por sua vez, a variável água encanada apresentou associação estatisticamente significativa em relação à variável episódio diarreico no último mês (teste qui-quadrado: $\mathrm{p}=0,008)$, sendo que 73,6\% (n=64) dos moradores entrevistados que possuem água encanada dentro de casa responderam "sim" quando questionados sobre a ocorrência de episódio diarreico no último mês, enquanto $26,4 \%(n=23)$ responderam "não".

O achado é corroborado pelo fato de que, apesar, da incidência da diarreia ter sua explicação envolta em aspectos multifatoriais, a disponibilidade de água encanada é referenciada enquanto importante determinante de ocorrência para o agravo diarreico. Isto acontece uma vez que a facilidade do acesso da água encanada possibilita uma adequada higiene pessoal, doméstica e dos alimentos, sem o que não se pode interromper o ciclo de transmissão fecal-oral das enteroparasitoses ${ }^{(229)}$. Por outro lado, não se pode deixar de mencionar que o acesso à água para consumo de qualidade se caracteriza enquanto fator de proteção capaz de contribuir na interrupção da cadeia de transmissão das parasitoses ${ }^{(226)}$.

Sobre a presença de banheiro no interior da casa, é possível descrever que, tanto nas casas com banheiro interno quanto nas demais, foi relativamente alta a proporção de respostas afirmativas para ocorrência de episódios diarreicos. Essa associação casa com banheiro interno e ocorrência de episódio diarreico no último mês, apresentou 66,7\% (n=66) de respostas positivas. Comportamento similar ao encontrado na associação casa sem presença de banheiro interno e ocorrência de episódios diarreicos no último mês de $61,1 \%$ (n=33). 
Realidade que pode estar relacionada à inadequação e precariedade do sistema de esgotamento sanitário, que favorece a proliferação de vetores e micro-organismos causadores de doenças endêmicas e parasitoses, bem como a contaminação das águas dos mananciais de superfície $^{(220)}$.

Outra variável que também apresentou associação estatisticamente significativa (teste qui-quadrado: $\mathrm{p}=0,038$ ) em relação à ocorrência de episódios diarreicos foi à relacionada à presença de coliformes termotolerantes na água que abastece a residência. Assim, 71,6\% $(\mathrm{n}=63)$ das casas abastecidas com água que tiveram resultado positivo quanto à analise microbiológica para coliformes termotolerantes também tiveram seus moradores referindo episódios diarreicos no último mês.

A realização de algum tipo de tratamento com a água destinada ao consumo humano mostrou forte associação (teste qui-quadrado: $\mathrm{p} \leq 0,001$ ) com a ocorrência de diarreia no último mês. A ingestão de água não tratada pode ser caracterizada enquanto fator de risco detectado para o desenvolvimento de doenças parasitárias intestinais, uma vez que quem consume água não filtrada apresenta 15,9 vezes mais chances de adquirir enteroparasitoses do que os que têm por hábito ingerir água após tratamento eficaz de filtragem ${ }^{(230)}$, o que corrobora resultados descritos.

No grupo que afirmou não realizar tratamento na água utilizada para beber, identificou-se que 82,9\% ( $\mathrm{n}=63)$ dos moradores apresentaram episódio diarreico nos últimos trinta dias, ou seja, nas localidades onde não existe o hábito do consumo de água filtrada ou fervida, a população torna-se vulnerável aos agravos transmitidos pela água sem tratamento, contexto que inclui todos os eventos diarreicos infecciosos.

Sobre a lavagem das mãos após as eliminações fisiológicas, pôde-se constatar que tal variável, quando associada à variável ocorrência de episódio diarreico no último mês, não apresentou significância estatística. Contudo, a não ocorrência de episódios diarreicos foi proporcionalmente menor dentre os moradores Kalungas que referiram regularidade na lavagem das mãos após as eliminações $(n=16 ; 28,1 \%)$, quando comparado aos que referiram não possuir o referido hábito $(\mathrm{n}=38 ; 39,6 \%)$.

Em linhas gerais, dentre os resultados deste estudo, destaca-se que os moradores Kalungas pesquisados apresentaram infestações por diferentes espécies de parasitos associados a episódios diarreicos nos últimos trinta dias, ademais os casos de diarreia estão 
fortemente associados às condições de higiene precárias, com destaque para a falta de tratamento da água destinada ao consumo.

\subsection{DESCRIÇÃO DAS CONDIÇÕES SANITÁRIAS, AMBIENTAIS E DE SAÚDE}

\subsubsection{Aspectos sanitários e ambientais de moradores das comunidades quilombolas Kalungas}

O saneamento constitui o controle de todos os fatores do meio físico do homem, que exercem efeitos deletérios sobre sua saúde, seja este impacto no bem-estar físico, mental ou social. Assim, a cobertura de água encanada, coleta de esgoto e de lixo são alguns indicadores de grande importância na definição dos perfis de saúde da população em geral ${ }^{(231)}$. Na Tabela 7, são mostrados alguns aspectos relacionados às condições sanitárias e de vida da Comunidade Kalunga. 
Tabela 7 - Características sanitárias e ambientais dos quilombolas Kalungas, em 2012

\begin{tabular}{|c|c|c|c|c|}
\hline \multirow[b]{2}{*}{ Variáveis } & \multicolumn{4}{|c|}{ Municípios } \\
\hline & $\begin{array}{c}\text { Cavalcante } \\
\mathrm{n}(\%)\end{array}$ & $\begin{array}{c}\text { Teresina de } \\
\text { Goiás } \\
\mathrm{n}(\%)\end{array}$ & $\begin{array}{c}\text { Monte } \\
\text { Alegre } \\
\mathrm{n}(\%)\end{array}$ & $\begin{array}{l}\text { Total } \\
\mathrm{n}(\%)\end{array}$ \\
\hline \multicolumn{5}{|c|}{ Proveniência da água (rios e nascentes) } \\
\hline Sim & $31(100,0)$ & $71(100,0)$ & $99(100,0)$ & $201(100,0)$ \\
\hline Não & - & - & - & - \\
\hline \multicolumn{5}{|c|}{ Tratamento com a água de consumo } \\
\hline Sim & $19(61,3)$ & $40(56,3)$ & $36(36,4)$ & $95(47,3)$ \\
\hline Não & $12(38,7)$ & $31(43,7)$ & $63(63,6)$ & $106(52,7)$ \\
\hline \multicolumn{5}{|c|}{$\begin{array}{l}\text { Água com presença de coliformes } \\
\text { termotolerantes }\end{array}$} \\
\hline Sim & $31(100,0)$ & $71(100,0)$ & - & $102(50,7)$ \\
\hline Não & - & - & $99(100,0)$ & $99(49,3)$ \\
\hline \multicolumn{5}{|c|}{ Destino inadequado dos dejetos } \\
\hline Sim & $14(45,2)$ & $48(67,6)$ & $90(90,9)$ & $152(75,6)$ \\
\hline Não & $17(54,8)$ & $23(32,4)$ & $9(9,1 \%)$ & $49(24,4)$ \\
\hline \multicolumn{5}{|c|}{ Destino do lixo domiciliar (queima) } \\
\hline Sim & $30(96,8)$ & $60(84,5)$ & $99(100,0)$ & $189(94,0)$ \\
\hline Não & $1(3,2)$ & $11(15,5)$ & - & $12(6,0)$ \\
\hline \multicolumn{5}{|l|}{ Hábito de ingerir hortaliças } \\
\hline Sim & $28(90,3)$ & $23(32,3)$ & $45(45,5)$ & $96(47,8)$ \\
\hline Não & $3(9,7)$ & $48(67,7)$ & $54(54,5)$ & $105(52,2)$ \\
\hline \multicolumn{5}{|c|}{ Presença de animais domésticos } \\
\hline Sim & $31(100,0)$ & $71(100,0)$ & $99(100,0)$ & $201(100,0)$ \\
\hline Não & - & - & - & - \\
\hline \multicolumn{5}{|c|}{$\begin{array}{l}\text { Hábito de lavar as mãos após as } \\
\text { eliminações fisiológicas }\end{array}$} \\
\hline Sim & $12(38,7)$ & $21(29,6)$ & $30(30,3)$ & $63(31,3)$ \\
\hline Não & $19(61,3)$ & $50(70,4)$ & $69(69,7)$ & $138(68,7)$ \\
\hline \multicolumn{5}{|c|}{$\begin{array}{l}\text { Episódio diarreico nos últimos dois } \\
\text { meses }\end{array}$} \\
\hline Sim & $31(100,0)$ & $53(74,6)$ & $91(91,9)$ & $175(87,1)$ \\
\hline Não & - & $18(25,4)$ & $8(8,1)$ & $26(12,9)$ \\
\hline
\end{tabular}

Todos os moradores informaram $(\mathrm{n}=201 ; 100 \%)$ que a água utilizada para o consumo geral da casa, incluindo ingesta e preparo de alimentos, provém diretamente de rios ou nascentes da região. Resultado semelhante foi evidenciando na população quilombola de Caiana dos Crioulos, no Estado da Paraíba. Em ambas as comunidades, Kalunga e Caiana dos Crioulos, $100 \%$ da população estudada não está ligada a um sistema público de abastecimento de água capaz de captar a água bruta do meio ambiente, depois tratá-la adequadamente para torná-la potável e, por último, distribuí-la até os consumidores, em quantidade suficiente para suprir suas necessidades ${ }^{(90)}$.

Além do problema envolvendo o abastecimento de água na região, soma-se a isto o fato de que, dentre estes moradores, mais da metade $(n=106 ; 52,7 \%)$ referiu não realizar tratamento na água antes de ingerir. Tal situação de inobservância da relevância da realização 
de tratamento eficaz da água antes de beber também foi identificada em mais da metade $(51,8 \%)$ dos quilombolas estudados da Comunidade Boqueirão, na região de Vitória da Conquista, Bahia. Já entre os moradores de Caiana dos Crioulos, este percentual foi menor, 15,6\% não realiza qualquer tipo de tratamento com a água de consumo, comportamento descrito por Kightlinger, Seed e Kightlinger ${ }^{(232)}$ como de risco para a aquisição de doenças de veiculação hídrica, entre as quais algumas enteroparasitoses. Houve forte associação estatística entre as variáveis tratamento prévio com a água e o local (município) de moradia (teste qui-quadrado: $\mathrm{p} \leq 0,001$ ).

A partir da análise microbiológica das águas que abastecem as residências, constatouse que, a partir do teste de associação de qui-quadrado, a variável presença de coliformes termotolerantes também apresentou significado estatístico em sua associação com a variável: município de moradia, sendo $\mathrm{p} \leq 0,001$. Os resultados apontaram ainda que, dentre as casas cujas fontes de abastecimento de água compuseram a amostra para a realização dos exames microbiológicos laboratoriais para a identificação da presença de coliformes termotolerantes, em mais da metade $(n=102 ; 50,7 \%)$ foi identificado algum grau da presença de coliformes termotolerantes. Achado que pode evidenciar, sob o aspecto sanitário, o consumo pelos moradores Kalungas de águas fora dos padrões de qualidade preconizados pelo Ministério da Saúde ${ }^{(227)}$.

Dentre estas $(\mathrm{n}=102), 58,8 \%(\mathrm{n}=60)$ são acumuladas em poços próximos às moradias Kalungas visando posterior consumo humano; 29,4\% ( $\mathrm{n}=30)$ provêm de busca ativa diária pelos moradores nos rios e fontes locais; e 11,8\% $(n=12)$ chegam às residências por meio da utilização de mangueiras e com drenagem gravitacional.

O destino final dos dejetos humanos mais referidos pelos moradores foi a fossa negra, o quintal ou o mato $(n=152 ; 75,6 \%)$. Apenas $24,4 \%(n=49)$ dos quilombolas do estudo apontaram o uso da fossa séptica como destinação de excretas em suas respectivas moradias. Dentre os moradores Kalungas que referiram a destinação dos dejetos humanos diretamente no meio ambiente $(\mathrm{n}=152) ; 73,2 \%(\mathrm{n}=111)$ referiram ocorrência de episódios diarreicos nos últimos dois meses, e 79,2\% $(\mathrm{n}=120)$ também apresentaram positividade quanto ao exame parasitológico de fezes.

As parasitoses intestinais, causadoras de diarreia ou não, estão intimamente relacionadas às condições sanitárias, pois, para que ocorra transmissão de uma doença 
parasitária, existe a necessidade da presença simultânea de hospedeiros suscetíveis (corpo para o parasita habitar), agentes causadores (o parasita) e eventualmente agentes transmissores (vetores), o que é frequentemente facilitado pela contaminação do meio ambiente com dejetos humanos e animais ${ }^{(233)}$.

A variável destino dos dejetos humanos apresentou significado estatístico quando associada ao município de residência (teste qui-quadrado: $p \leq 0,001$ ). Assim, Monte Alegre apresentou 90,9\% $(\mathrm{n}=90)$ de respostas afirmativas quanto ao destino inadequado dado aos dejetos humanos, Teresina de Goiás 67,6\% (n=48) e Cavalcante 45,2\% ( $n=14)$.

Sobre a questão do lixo na Comunidade Kalunga e a sua presença no ambiente, identificou-se que o acúmulo no quintal para posterior queima próximo ao período das chuvas foi mencionado como principal meio de eliminação dos resíduos sólidos domiciliares. Contudo, sabe-se que o lixo disposto de qualquer maneira e sem atender normas de controle sanitário pode contribuir com a ocorrência de inúmeros problemas ambientais e de saúde pública, podendo causar tanto a contaminação das águas subterrâneas e do solo, quanto a proliferação de ratos, baratas e outros insetos transmissores de doenças e agravos em saúde $^{(234)}$.

Os resultados também apontam que 94,0\% dos moradores $(n=189)$ referem acumular o lixo no terreno para queimada, sem a definição de local específico para a deposição dos resíduos e sem preocupações quanto à separação seletiva. Em Monte Alegre esta destinação foi responsável por 100,0\% (n=99) das ocorrências, em Cavalcante 96,8\% (n=30) e em Teresina de Goiás 84,5\% (n=60). A variável em questão apresentou significância estatística na associação com o município de residência, sendo $\mathrm{p} \leq 0,001$.

A maioria dos sujeitos $(\mathrm{n}=178 ; 88,6 \%)$ respondeu negativamente quando questionados sobre a existência da prática de separação entre tipos de lixo. Entre o grupo que realiza algum tipo de diferenciação na deposição dos resíduos sólidos produzidos no domicílio (n=23), $69,5 \%(n=16)$, referiu separar os restos de alimentos uma vez que estes não precisam ser queimados; 17,4\% $(n=4)$ separa o vidro do restante do lixo, e 13,1\% (n=3) informou outros tipos de separação.

Vieira e Monteiro ${ }^{(58)}$ corroboram com os achados e inferem que, em geral, os Kalungas depositam o lixo domiciliar produzido a céu aberto, realizando processo de queimada periódica destes resíduos, sem maiores preocupações com a separação seletiva. 
$\mathrm{Na}$ Figura 7, são mostradas as proporções de respostas acerca dos principais problemas citados pelos sujeitos do estudo como decorrentes do acúmulo de lixo no quintal e próximo às residências Kalungas.

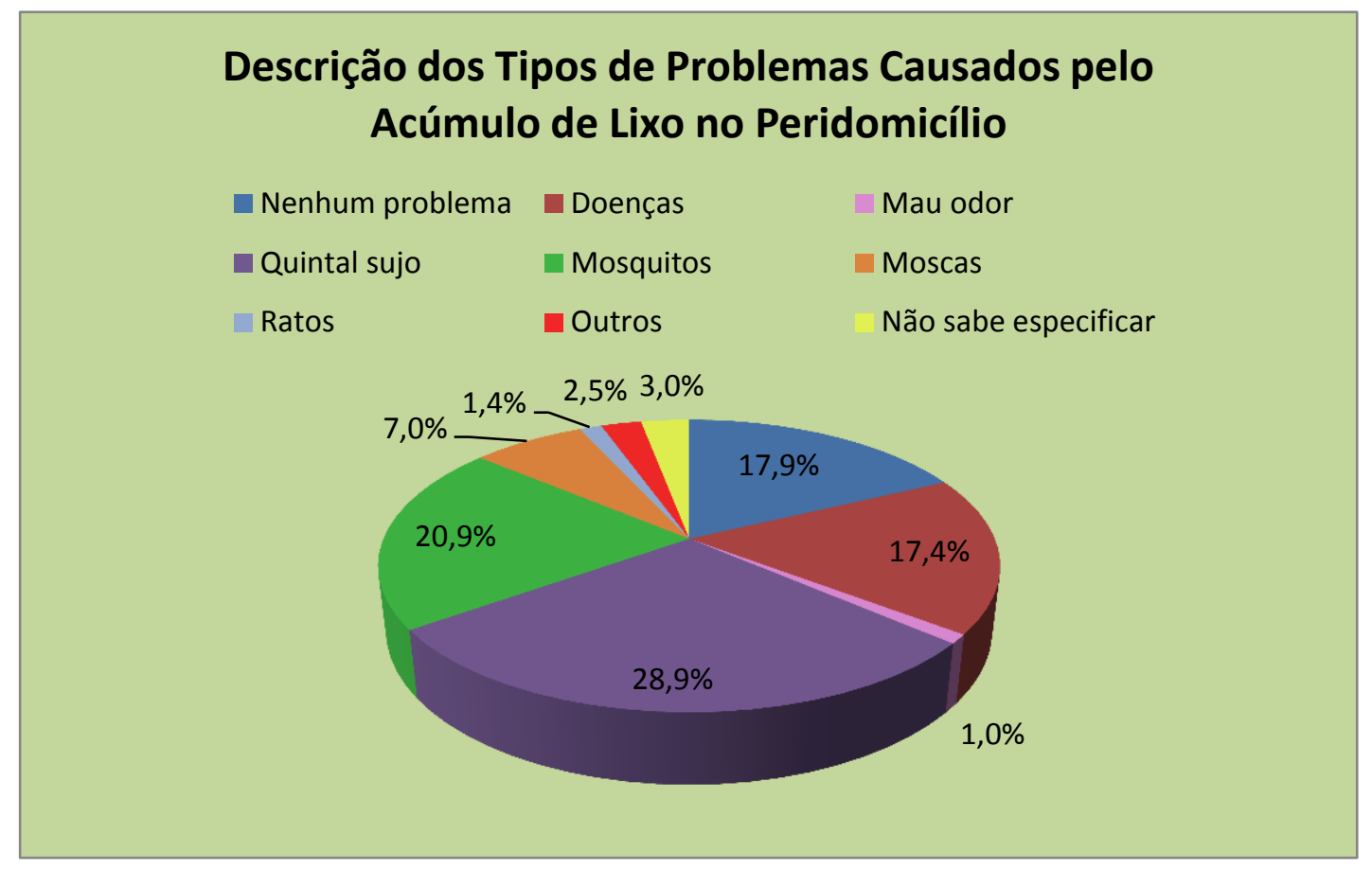

Figura 7 - Principais consequências do acúmulo de lixo no espaço peridomiciliar

Verifica-se, na figura, que a maioria dos moradores Kalungas no estudo ( $n=94 ; 46,8 \%$ ) não estabeleceu uma relação, seja esta direta ou indireta, entre o acúmulo de lixo no espaço peridomiciliar e o aumento do risco para agravos em saúde. Em 28,9\% (n=58) dos casos foi citada exclusivamente a questão estética evidenciada em um quintal sujo, e, ainda, 17,9\% $(n=36)$ dos participantes referiu a inexistência de qualquer problema decorrente do acúmulo de lixo. Por outro lado, a proliferação de vetores (mosquitos e moscas) e animais sinantrópicos (roedores) emergiu com 29,4\% (n=59) das referências, bem como a associação direta entre o acúmulo do lixo e a possibilidade de doenças foi estabelecida por $17,4 \%$ (n=35) dos moradores. 3,0\% $(n=6)$ dos respondentes não souberam especificar as consequências do acúmulo de lixo, apesar de afirmarem existir problemas relacionados à presença deste tipo de resíduos próximo às casas. Outros problemas perfizeram $2,5 \%(n=5)$ das ocorrências e, por fim, o mau odor representou $1,0 \%(n=2)$ das respostas dos moradores.

O consumo de hortaliças foi referido por 47,8\% (n=96) dos Kalungas que participaram da pesquisa, sendo, na maioria das vezes, tais alimentos provenientes do plantio no roçado ou no próprio quintal das casas. No município de Cavalcante houve o maior número de citações quanto ao hábito do consumo de hortaliças $(n=28 ; 90,3 \%)$, seguida de Monte Alegre $(n=45$; 
45,5\%) e Teresina de Goiás ( $n=23 ; 32,3)$. Pode-se afirmar que pelo teste do qui-quadrado houve significado estatístico na associação entre município de residência e hábito de ingerir hortaliças, com $\mathrm{p}=0,001$. Constatou-se, também, que a totalidade $(\mathrm{n}=201 ; 100,0 \%)$ dos domicílios visitados apresentava animais domésticos, sendo mais comum a presença de aves, suínos, equinos e cães.

Frente ao exposto, destaca-se que o consumo de verduras cruas constitui importante fator de risco para a transmissão de várias doenças infecciosas e parasitárias quando associados à frequente prática de irrigação de hortas com água contaminada por matéria fecal ou mesmo adubada com dejetos humanos ou de animais de sangue quente ${ }^{(235)}$.

Em referência aos hábitos de higiene pessoal, pôde-se afirmar que dentre os moradores entrevistados, apenas 31,3\% ( $\mathrm{n}=63)$ responderam afirmativamente quando questionados sobre a lavagem regular das mãos após as eliminações fisiológicas. Lavagem das mãos após as evacuações e antes do contato com alimentos é descrita como importante hábito de higiene e um dos principais tópicos da profilaxia das parasitoses intestinas, uma vez que contribui, significativamente, com a interrupção da cadeia de transmissão do agravo, por meio rompimento do ciclo oro-fecal ${ }^{(236)}$.

Não houve significado estatístico entre esta variável, hábito de lavar as mãos após as eliminações fisiológicas, e a presença de água encanada no interior da residência (teste quiquadrado: p=0,288). Em adição, não foi estatisticamente significativa a associação entre o município de moradia dos quilombolas Kalungas e a prática de lavagem frequente das mãos após as eliminações fisiológicas (teste qui-quadrado: $\mathrm{p}=0,635$ ).

A OMS conceitua diarreia como uma alteração de hábito intestinal caracterizada por aumento no número de evacuações e/ou diminuição da consistência das fezes devido à presença de água e eletrólitos. Esta se caracteriza em importante causa de morbidade principalmente quando se consideram regiões de baixo nível socioeconômico, onde em diversas delas é evidente a deficiência em saneamento básico, como o que acontece com os remanescentes quilombolas Kalungas.

Nesta comunidade, a ocorrência de diarreia nos últimos dois meses foi descrita por $87,1 \%$ ( $\mathrm{n}=175)$ dos entrevistados. $\mathrm{E}$, quando o questionamento estreitou o intervalo de tempo, episódio diarreico no último mês, o valor encontrado para os casos positivos manteve-se com proporção predominante $(n=49 ; 69,2 \%)$ em relação aos casos negativos $(n=22 ; 30,8 \%)$. A 
associação desta variável com o município de residência apresentou forte significado estatístico (teste qui-quadrado: $\mathrm{p} \leq 0,001$ ).

Acrescenta-se ainda que, dentre os moradores que referiram episódio diarreico nos últimos dois meses $(\mathrm{n}=175), 55,2 \% \quad(\mathrm{n}=96)$ utilizam mangueiras para captar a água proveniente dos rios com vistas ao consumo humano; 28,5\% ( $\mathrm{n}=50)$ acumulam a água dos rios em poços; e 16,4\% (n=29) buscam diariamente a água nos rios em baldes ou galões para o consumo familiar.

\subsubsection{Aspectos ambientais relativos à ação antrópica: investigação sobre possível contaminação, no ambiente e em moradores quilombolas kalungas, decorrente de atividade mineradora na região}

O conhecimento das características de uma comunidade, sua dinâmica interna e as relações estabelecidas entre saúde, ambiente e condições de vida podem ser citados como importantes aliados ao se refletir sobre as possibilidades de atuação, tanto de enfermeiros quanto dos demais profissionais da equipe multiprofissional, com vistas à diminuição de eventuais agravos, vez que a saúde pública tem forte componente horizontal, reconhecendo as particularidades de cada população e adequando-se a elas ${ }^{(35)}$.

O mercúrio é considerado um metal tóxico extensamente estudado em todo mundo, com distribuição no ambiente por fontes naturais ou antropogênicas e capaz de fornecer risco às populações por acarretar efeitos nocivos ao ecossistema e à saúde humana ${ }^{(170)}$. As atividades desenvolvidas em garimpos de ouro podem ser citadas como um fator antropogênico responsável pelo aumento da carga total de mercúrio presente no meio ambiente. Por isso, o risco de contaminação por mercúrio, originada nos garimpos, tem sido alvo de preocupação na área ambiental e da saúde pública ${ }^{(170)}$.

Isto ocorre uma vez que durante o processo de extração e amalgamação do minério do ouro, grande parte do mercúrio empregado é depositada nos sedimentos bênticos. A partir daí, por uma série de reações químicas, o mercúrio inorgânico é transformado em metilmercúrio, composto orgânico altamente tóxico. Este, por sua vez, é bioacumulado e biomagnificado, atingindo concentrações maiores ao longo da cadeia trófica aquática, chegando até o homem por meio da dieta alimentar ${ }^{(177)}$. 
Assim, sobre a presença do mercúrio enquanto agente de possível impacto nas condições ambientais e de saúde da comunidade quilombola Kalunga, verificou-se o teor deste metal em alguns espécimes de peixes consumidos na localidade, bem como em amostras de cabelo de moradores. Na contaminação ambiental, enfatizada neste tópico do estudo, a presença do mercúrio pode acarretar comprometimento da biota de áreas direta ou indiretamente afetadas pela atividade garimpeira, chegando até o homem, comumente, por meio da ingestão de peixes, apontada como a principal via de intoxicação do ser humano por mercúrio $^{(178)}$.

A área habitada pelos Kalungas está sob a influência da bacia hidrográfica do rio Paranã, onde a atividade garimpeira é praticada e ocorre liberação de $\mathrm{Hg}$ para o ambiente. O peixe tanto absorve o metilmercúrio da água quanto pela ingestão de organismos aquáticos $^{(176)}$. $\mathrm{O} \mathrm{Hg}$ nos peixes está principalmente na forma de $\mathrm{MeHg}$, sendo estes animais considerados importantes biomarcadores utilizados por diferentes organizações e pesquisadores com o objetivo de avaliar os níveis de contaminação de determinada biota aquática, em especial, na checagem da qualidade dos pescados disponíveis para a população ${ }^{(169)}$. Em outras palavras, a importância do monitoramento dos níveis de $\mathrm{Hg}$ em frutos do mar e derivados está associada à avaliação de eventuais riscos toxicológicos para as populações.

O risco de intoxicação pela ingestão de peixe contaminado depende de alguns fatores, sendo que o teor de mercúrio, a quantidade ingerida e a frequência de ingestão são determinantes para a acumulação da forma orgânica deste metal pesado, metilmercúrio, no organismo humano ${ }^{(237)}$. Entre os moradores Kalungas que participaram do estudo, as referências quanto ao quantitativo da massa de peixe ingerida por porção variaram de 40 a 200 g, sendo o valor médio encontrado para cada porção consumida igual a aproximadamente 60 gramas de pescado.

Na Tabela 8, são apresentadas as frequências do consumo de peixe enquanto item do cardápio de moradores da comunidade Kalunga, segundo município de moradia. 
Tabela 8 - Frequência do consumo de pescados segundo município de moradia no Sítio Histórico e Patrimônio

\begin{tabular}{l|c|c|c|c}
\hline \multicolumn{4}{c}{ Cultural Kalunga, em 2012} \\
\cline { 2 - 5 } Variáveis & $\begin{array}{c}\text { Municípios } \\
\text { Cavalcante } \\
\end{array}$ & $\begin{array}{c}\text { Teresina de } \\
\text { Goiás } \\
\mathrm{n}(\%)\end{array}$ & $\begin{array}{c}\text { Monte } \\
\text { Alegre } \\
\mathrm{n}(\%)\end{array}$ & $\begin{array}{c}\text { Total } \\
\mathrm{n}(\%)\end{array}$ \\
\hline Frequência do consumo de peixe & & & & \\
Nunca & $3(9,7)$ & $1(1,4)$ & $5(5,0)$ & $9(4,5)$ \\
Uma vez por mês & $19(61,3)$ & $5(7,0)$ & $43(43,4)$ & $67(33,3)$ \\
Uma vez a cada quinze dias & - & $21(29,6)$ & $7(7,1)$ & $28(13,9)$ \\
Uma a duas vezes por semana & $4(12,9)$ & $15(21,1)$ & $17(17,2)$ & $36(17,9)$ \\
Três ou mais vezes por semana & $1(3,2)$ & $22(31,0)$ & $27(27,3)$ & $50(24,9)$ \\
Outros & $4(12,9)$ & $7(9,9)$ & - & $11(5,5)$ \\
\hline
\end{tabular}

Verificou-se que a maioria dos moradores que participaram do estudo ( $\mathrm{n}=192 ; 95,5 \%)$ respondeu afirmativamente em relação à utilização da carne do peixe na alimentação. Por município, a proporção de consumo de peixe é de 98,6\% (n=70) em Teresina de Goiás, 94,9\% $(n=94)$ em Monte Alegre e 90,3\% (n=28) em Cavalcante.

Com relação à frequência do consumo de pescado, pode-se inferir que em Cavalcante, $61,3 \%(n=19)$ dos moradores da amostra estudada consome peixe em média uma vez por mês; $12,9 \% 9(n=4)$ entre uma e duas vezes por semana; e, 3,2\% $(n=1)$ três ou mais vezes a cada semana. Em Teresina de Goiás, a maior proporção encontrada foi em relação ao consumo do peixe igual ou superior a três vezes por semana $(31,0 \% ; 22)$, seguido das referências a uma vez por mês $(7,0 \%$; $n=5)$; uma vez a cada quinze dias $(29,6 \% ; 21)$; e uma ou duas vezes na semana $(21,1 \% ; n=15)$. Por fim, no município de Monte Alegre a maioria dos Kalungas entrevistados referiu a inclusão do peixe no cardápio familiar em média uma vez por mês; $27,3 \%(n=27)$ três ou mais vezes por semana; $17,2 \%(n=17)$ uma ou duas vezes a cada semana e 7,1\% ( $\mathrm{n}=7)$ uma vez a cada quinze dias. Observou-se forte significado estatístico (teste qui-quadrado: $p \leq 0,001$ ) na associação entre as variáveis frequência do consumo de peixe e município de moradia.

Para complementar o descrito anteriormente, na Figura 8, são mostrados os dados sobre o consumo de peixe a partir da padronização temporal por semana. Assim, identificouse que entre os participantes do estudo que consomem peixe em suas refeições $(n=172$; $85,6 \%), 61,6 \%(n=106)$ se alimentam de peixe com frequência menor ou igual a uma vez por semana, enquanto os demais, 38,4\% $(n=66)$ referiram consumir peixe de duas a sete vezes no período. Pode-se constatar a predominância do consumo eventual de peixes $(n=168 ; 97,7 \%)$ sobre o consumo diário $(n=4 ; 2,3 \%)$. 


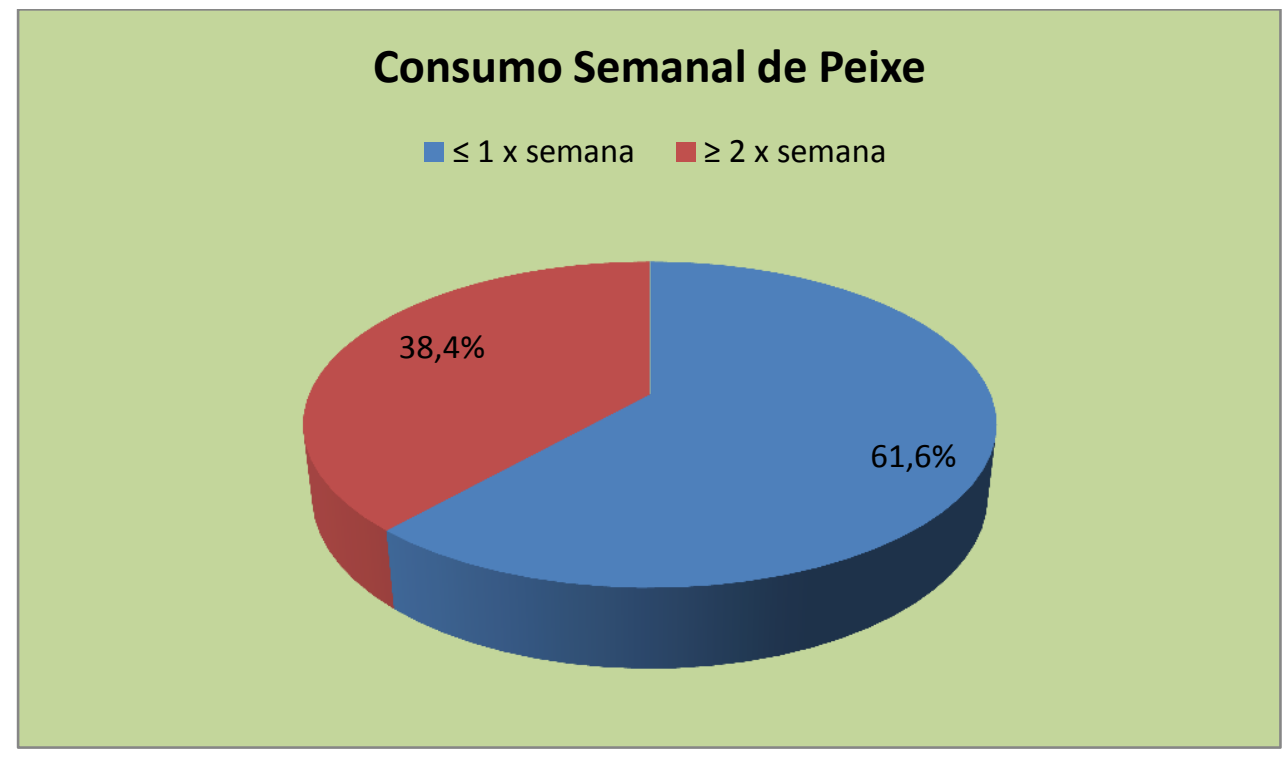

Figura 8-Consumo semanal de peixe por moradores Kalungas

Com relação à etapa de investigação analítica e com vistas à obtenção de dados sobre a presença de mercúrio em peixes da região do Sítio Histórico e Patrimônio Cultural Kalunga, foram coletadas amostras de tecido muscular destes animais. As espécies que compuseram a amostra foram o prapeté ou curimatã (Prochilodus lineatus), o piau (Leoporinus obtusidens), o corro (Astronotus ocellatus), a bicuda (Boulengerella maculata), a cachorra-facão ou camoteira (Rhaphidon vulpinus), o tucaré ou pirapitinga (Piaractus bracypomus), piranhapreta (Serrasalmus rhombeus) e o pacu (Piaractus mesopotamicus).

Ao todo foram analisadas, quanto ao conteúdo do mercúrio total, 42 amostras de tecido muscular estriado esquelético de peixes pertencentes a oito espécies diferentes, todas referidas pelos moradores como de consumo na comunidade.

Na Tabela 9, são mostrados os nomes popular e científico dos espécimes, bem como os dados de caracterização da amostra segundo comprimento, massa, hábito alimentar e quantitativo de peixes por espécie analisada. 
Tabela 9 - Caracterização dos peixes por espécie, hábito alimentar, comprimento e massa no Sítio Histórico e Patrimônio Cultural Kalunga, em 2012

\begin{tabular}{|c|c|c|c|c|c|}
\hline \multirow{2}{*}{ Espécie } & \multirow{2}{*}{$\mathrm{n}$} & \multicolumn{2}{|c|}{ Comprimento $(\mathrm{cm})$} & \multicolumn{2}{|c|}{ Massa (g) } \\
\hline & & Faixa & Média $\pm \mathrm{DP}$ & Faixa & Média $\pm \mathrm{DP}$ \\
\hline $\begin{array}{l}\text { Prochilodus lineatus } \\
\text { (prapeté ou curimatã) }-(\mathrm{NP})\end{array}$ & 18 & $\begin{array}{l}16,400- \\
23,500\end{array}$ & $18,383 \pm 2,215$ & $51,00-138,000$ & $80,056 \pm 27,875$ \\
\hline $\begin{array}{l}\text { Leoporinus obtusidens } \\
\text { (piau) }-(\mathrm{NP})\end{array}$ & 6 & $\begin{array}{c}13,600- \\
17,700\end{array}$ & $15,767 \pm 1,875$ & $23,000-78,000$ & $49,333 \pm 23,981$ \\
\hline $\begin{array}{l}\text { Astronotus ocellatus } \\
\text { (corró) }-(\mathrm{NP})\end{array}$ & 2 & $\begin{array}{l}9,500- \\
12,300\end{array}$ & $10,900 \pm 1,980$ & $15,000-30,000$ & $22,500 \pm 10,607$ \\
\hline $\begin{array}{l}\text { Boulengerella maculata } \\
\text { (bicuda) }-(\mathrm{P})\end{array}$ & 2 & $\begin{array}{l}19,400- \\
20,300\end{array}$ & $19,850 \pm 0,636$ & $58,000-63,000$ & $60,500 \pm 3,536$ \\
\hline $\begin{array}{l}\text { Rhaphiodon vulpinus } \\
\text { (cachorra-facão ou camoteira) - } \\
\text { (P) }\end{array}$ & 2 & $\begin{array}{c}49,400- \\
51,100\end{array}$ & $50,250 \pm 1,202$ & $\begin{array}{l}538,000- \\
554,000\end{array}$ & $\begin{array}{c}546,000 \pm 11,31 \\
4\end{array}$ \\
\hline $\begin{array}{l}\text { Piaractus bracypomus } \\
\text { (tucaréou pirapitinga) - (NP) }\end{array}$ & 7 & $\begin{array}{l}17,100- \\
24,200\end{array}$ & $20,900 \pm 2,915$ & $34,000-176,000$ & $94,143 \pm 49,751$ \\
\hline $\begin{array}{l}\text { Serrasalmus rhombeus } \\
\text { (piranha-preta) }-(\mathrm{P})\end{array}$ & 2 & $\begin{array}{l}9,500- \\
19,600\end{array}$ & $14,550 \pm 7,142$ & $12,000-122,000$ & $67,000 \pm 77,782$ \\
\hline $\begin{array}{l}\text { Piaractus mesopotamicus } \\
\text { (pacu) }-(\mathrm{NP})\end{array}$ & 3 & $\begin{array}{l}9,300- \\
15,600\end{array}$ & $13,133 \pm 3,365$ & $10,000-102,000$ & $51,333 \pm 46,705$ \\
\hline
\end{tabular}

Sobre o tamanho dos peixes que compuseram a amostra, entre os 42 espécimes, o menor apresentou comprimento total igual a 9,300 cm, o maior 51,100 cm, com tamanho médio de 19,102 cm, mediana de 17,300 e DP=7,893. Já em relação à massa, pôde-se afirmar que esta variou de 10,000 g a 554,000, sendo o peso médio dos peixes igual a 93,857 g, mediana de 67,000 e $\mathrm{DP}=108,770$.

Em detalhamento por espécie (Tabela 9), a cachorra-facão ou camoteira (Rhaphidon vulpinus) apresentou o maior valor médio de comprimento $(50,250 \mathrm{~cm})$ e média de peso de 546,000 g. Em seguida identificou-se a espécie tucaré ou pirapitinga (Piaractus bracypomus) com valores médios de comprimento e massa de 20,900 cm e 94,140 g. A bicuda (Boulengerella maculata) teve uma média de comprimento de 19,850 cm e com peso médio de 60,500 g. Dentre os exemplares da espécie prapeté ou curimatã (Prochilodus lineatus), o tamanho médio foi de 18,383 cm, com massa média de 80,056 g. Já os valores médios de comprimento e peso encontrados para os espécimes de piau (Leoporinus obtusidens) foram de $15,767 \mathrm{~cm}$ e 49,333 g, respectivamente; dentre os peixes da espécie piranha-preta (Serrasalmus rhombeus) os dados foram de $14,550 \mathrm{~cm}$ para média de comprimento e $67,000 \mathrm{~g}$ para o peso médio. Por fim, os menores valores foram encontrados para o pacu (Piaractus mesopotamicus) com tamanho médio de $13,133 \mathrm{~cm}$ e média de peso de 51,333 g; e, para, o corró (Astronotus ocellatus) com 10,900 cm e 22,500g. 
$\mathrm{Na}$ Tabela 10, são mostrados os resultados obtidos quanto às concentrações médias e variações de mercúrio segundo as espécies analisadas no Sítio Histórico e Patrimônio Cultural Kalunga. O levantamento dos níveis de mercúrio contaminante nas diferentes espécies de pescado utilizadas como alimento pelos grupos populacionais, como também a monitoração sistemática dessa contaminação, podem prever e impedir uma possível situação de risco à Saúde Pública ${ }^{(238)}$.

Neste estudo, verificou-se que, no geral, a concentração média encontrada está abaixo do valor fornecido pela $\mathrm{OMS}^{(239)}$, de $500 \mathrm{ng}^{-\mathrm{g}^{-1}}$, e pela Agência Nacional de Vigilância Sanitária do Ministério da Saúde (ANVISA) ${ }^{(241)}$, de 500 ng.g ${ }^{-1}$ para espécies não carnívoras, e $1.000 \mathrm{ng} \cdot \mathrm{g}^{-1}$ para espécies carnívoras. Estes valores de referência visam minimizar eventuais casos de intoxicação alimentar causada pelo consumo de mercúrio, contribuindo com a saúde pública e com a identificação ambiental de possíveis áreas contaminadas e suas fontes emissoras de $\mathrm{Hg}$. Assim, resultados encontrados acima do limite permitido pela legislação brasileira vigente classificariam o pescado como impróprio para o consumo humano, em se tratando das normas para comercialização de alimentos.

Tabela 10 - Concentrações de Hg em diferentes espécies de peixes no Sítio Histórico e Patrimônio Cultural Kalunga, em 2012

\begin{tabular}{l|c|c|c|c}
\hline \multirow{2}{*}{ Nome Popular } & \multirow{2}{*}{ Nome Científico } & Espécimes & \multicolumn{2}{c}{ Concentração de Hg $(\mu \mathrm{g} / \mathrm{g})$} \\
\cline { 4 - 5 } & & $\mathrm{n})$ & Faixa & $\mathrm{Média} \pm \mathrm{DP}$ \\
\hline Prapeté ou Curimatã & Prochilodus lineatus & 18 & $0,033-0,173$ & $0,070 \pm 0,038$ \\
Piau & Leoporinus obtusidens & 6 & $0,092-0,424$ & $0,209 \pm 0,128$ \\
Corró & Astronotus ocellatus & 2 & $0,065-0,075$ & $0,070 \pm 0,008$ \\
Bicuda & Boulengerella maculata & 2 & $0,226-0,231$ & $0,229 \pm 0,004$ \\
Cachorra-facão ou Camoteira & Rhaphiodon vulpinus & 2 & $1,578-1,662$ & $1,620 \pm 0,059$ \\
Tucaré ou Pirapitinga & Piaractus bracypomus & 7 & $0,020-0,141$ & $0,051 \pm 0,042$ \\
Piranha-preta & Serrasalmus rhombeus & 2 & $0,137-0,254$ & $0,196 \pm 0,083$ \\
Pacu & Piaractus & 3 & $0,006-0,066$ & $0,033 \pm 0,030$ \\
& mesopotamicus & & & \\
\hline
\end{tabular}

O pacu - Piaractus mesopotamicus apresentou menor nível de contaminação por mercúrio $(0,006-0,066 \mu \mathrm{g} / \mathrm{g})$ do que o tucaré ou pirapitinga - Piaractus bracypomus $(0,020$ $0,141 \mu \mathrm{g} / \mathrm{g})$; prapeté ou curimatã - Prochilodus lineatus $(0,033-0,173 \mu \mathrm{g} / \mathrm{g})$; corró Astronotus ocellatus $(0,065-0,075 \mu \mathrm{g} / \mathrm{g})$; piranha-preta - Serrasalmus rhombeus $(0,137$ -

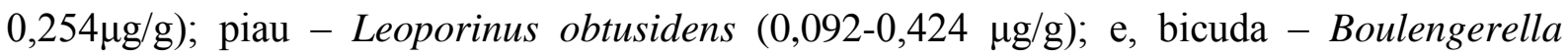
maculata $(0,226-0,231 \mu \mathrm{g} / \mathrm{g})$. A cachorra-facão ou camoteira - Rhaphiodon vulpinus apresentou o maior índice de contaminação $(1,578-1,662 \mu \mathrm{g} / \mathrm{g})$.

Na Figura 9, são mostradas as concentrações de mercúrio por espécime/espécie analisada. Em referência à situação dos teores de mercúrio dos peixes, a concentração média 
na amostra foi de $0,172 \mu \mathrm{gHg} / \mathrm{g}(\mathrm{DP}=0,339)$, sendo o valor máximo de $1,662 \mu \mathrm{gHg} / \mathrm{g}$ e o mínimo de $0,006 \mu \mathrm{gHg} / \mathrm{g}$.

Foi possível identificar, ainda, que em relação ao total de peixes, nove espécimes $(21,4 \%)$ apresentaram níveis de mercúrio igual ou superior ao teor médio encontrado para a amostra e $33(78,6 \%)$ abaixo.

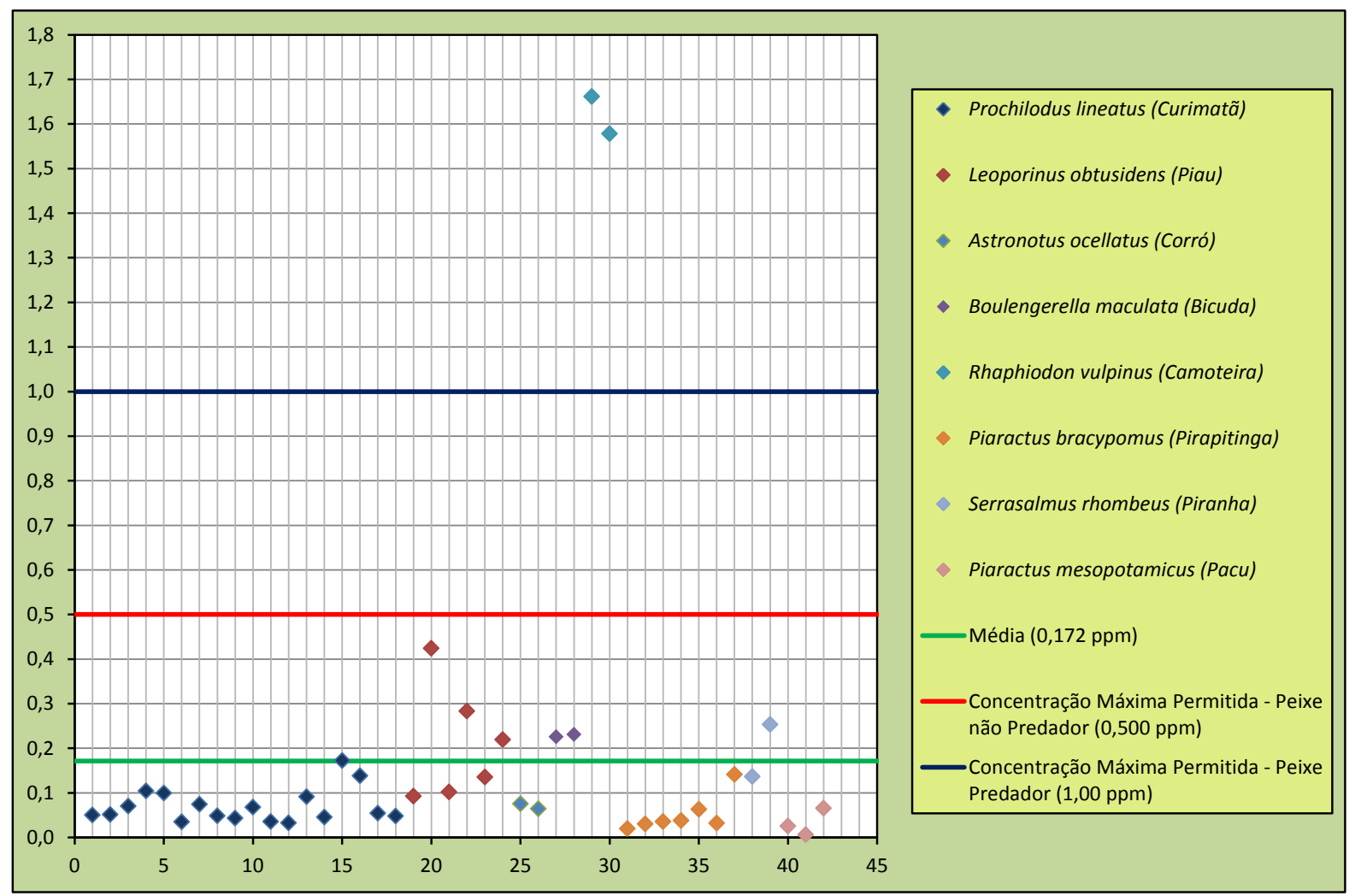

Figura 9 - Teor de mercúrio por espécime

Em relação à ictiofauna, cada espécie apresenta um caráter de absorção e acumulação diferenciado, de acordo com fatores biológicos específicos. Existem os peixes de nível trófico baixo, que são os herbívoros e detritívoros, os de nível trófico intermediário, os omnívoros, e finalmente os de nível trófico elevado, os piscívoros, também chamados de carnívoros ou predadores. Os herbívoros se alimentam basicamente de sementes e de frutos; os detritívoros se alimentam de matéria orgânica em decomposição e microrganismos associados à lama do fundo de lagos e margens de rios. Os detritos provindos da mata alagada, ninfas de insetos e zooplâncton são a base da alimentação dos omnívoros. Os piscívoros se alimentam de outros peixes e por isso bioacumulam o mercúrio em maior proporção ${ }^{(165)}$. 
Assim, o hábito alimentar pode ser citado como fator capaz de influenciar os níveis de mercúrio bioacumulados nos peixes, que acumulam mercúrio tanto do alimento como da coluna da água, sendo o alimento, sem dúvida, a fonte predominante de absorção de mercúrio.

$\mathrm{Na}$ amostra, as espécies predadoras foram representadas pela bicuda (Boulengerella maculata), piranha-negra (Serrasalmus rhombeus) e cachorra-facão ou camoteira (Rhaphiodon vulpinus). Já os peixes de hábito não predador incluíram os detritívoros: prapeté ou curimatã (Prochilodus lineatus); os omnívoros: piau (Leoporinus obtusidens), corró (Astronotus ocellatus) e pacu (Piaractus mesopotamicus); e os herbívoros: tucaré ou pirapitinga (Piaractus bracypomus), conforme descrito na Tabela 9.

Os resultados apontaram que os níveis de mercúrio nos peixes coletados podem estar relacionados aos hábitos alimentares das espécies, uma vez que os animais pertencentes aos níveis tróficos mais altos (predadores) apresentaram maior concentração média de mercúrio que os espécimes de níveis tróficos mais baixos (não predadores). Sobre isto, Filho e Campos ${ }^{(240)}$ descrevem que os níveis de $\mathrm{Hg}$ nas diferentes espécies tendem a aumentar devido aos processos de organificação em ambientes aquáticos no transporte do metal para as redes tróficas; a facilidade de absorção das espécies organomercuriais; bem como devido à baixa taxa de excreção, associados aos processos de bioacumulação e disponibilidade do metal no meio aquático.

O processo de bioacumulação pode ser entendido como o acúmulo de substâncias tóxicas e não biodegradáveis nos tecidos dos organismos, permanecendo em caráter cumulativo ao longo dos níveis tróficos da cadeia alimentar. No contexto do estudo, pode-se referir que a bioacumulação ocorre pela transferência do metilmercúrio acumulado no primeiro nível (produtores) para os consumidores, sendo que quanto mais longa a cadeia trófica, maior a concentração acumulado pelo consumidor. Os peixes são, assim, concentradores naturais de mercúrio, sendo as espécies carnívoras as que mais contribuem para o acúmulo de $\mathrm{MeHg}$, chegando a acumular nove vezes mais que outras espécies ${ }^{(174)}$. 


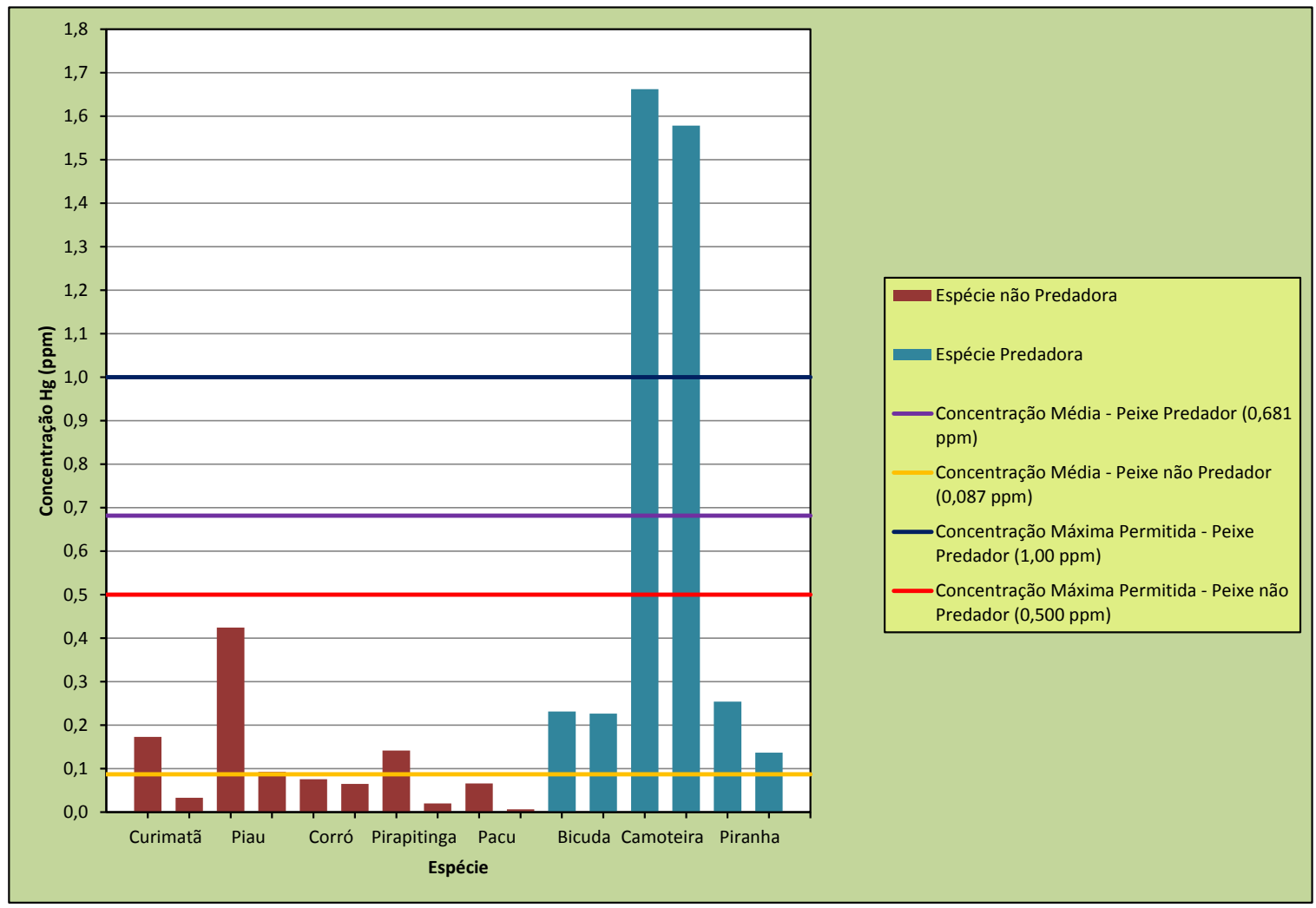

Figura 10 - Valor mínimo, máximo e teor médio de Hg por hábito alimentar das espécies

A Figura 10 mostra os valores máximo e mínimo de concentração de mercúrio nas diferentes espécies analisadas no estudo por grupo de hábito alimentar: predador ou não predador. Este ilustra o descrito anteriormente acerca da relação encontrada entre o hábito alimentar dos peixes e o teor de mercúrio presente em seu tecido muscular: os animais pertencentes aos níveis tróficos mais altos (predadores) apresentaram maior concentração média de mercúrio que os espécimes de níveis tróficos mais baixos (não predadores).

Observação semelhante foi descrita em estudo realizado em peixes coletados na bacia do Rio Amazonas, em seu principal afluente, o Rio Madeira. Segundo o autor, as diferenças entre os valores encontrados para a concentração de mercúrio nos exemplares de peixes de hábito alimentar predador e não predador podem estar associadas não só à variabilidade na dieta alimentar de cada espécie de peixe e capacidade, mas também a outras variáveis do meio aquático, tais como: dinâmica de fluxo, espessura da lâmina d'água, níveis de mercúrio nos sedimentos de fundo e em suspensão e nas comunidades planctônicas e bentônicas, sendo amplo o espectro de fatores capazes de impactar na concentração de mercúrio nos espécimes $\operatorname{analisados}^{(241)}$.

Com relação aos espécimes de peixes não carnívoros ou não predadores, verificou-se que as concentrações de $\mathrm{Hg}$ total no tecido muscular variaram de 0,006 $\mu \mathrm{g} / \mathrm{g}$ a 0,424. $\mu \mathrm{g} / \mathrm{g}$, 
dependendo da espécie considerada. O teor médio de mercúrio encontrado neste grupo foi de $0,087 \mu \mathrm{gHg} / \mathrm{g}(\mathrm{DP}=0,082)$.

Em detalhamento por espécie de hábito não predador, pôde-se observar que dentre os exemplares de piau (Leoporinus obtusidens), a concentração média de mercúrio foi de 0,209 $\mu \mathrm{g} / \mathrm{g}$ com DP=0,128; entre as amostras de tucaré ou pirapitinga (Piaractus bracypomus), de 0,051 $\mu \mathrm{gHg} / \mathrm{g}(\mathrm{DP}=0,042)$; e, para peixes da espécie pacu (Piaractus mesopotamicus), de $0,033 \mu \mathrm{gHg} / \mathrm{g}(\mathrm{DP}=0,030)$. Com relação aos peixes das demais espécies não predadoras estudadas, prapeté ou curimatã (Prochilodus lineatu) e corró (Astronotus ocellatus), ambos apresentaram médias de concentração de $\mathrm{Hg}$ similares, $0,070 \mu \mathrm{gHg} / \mathrm{g}$, com desvio padrão de 0,038 e 0,008 , respectivamente.

De tal forma, as espécies analisadas de pescado não predador apresentaram concentrações de mercúrio total abaixo dos limites estabelecidos pela legislação brasileira vigente (Portaria n. ${ }^{\mathrm{o}}$ 685/98), de $0,5 \mathrm{mg} / \mathrm{kg}$ para pescado não predador ${ }^{(239)}$, sendo o valor médio da concentração de $\mathrm{Hg}$ encontrada para o grupo correspondente a 17,4\% do limite máximo permitido (Figura 11). Valores encontrados acima do limite permitido pela legislação brasileira vigente sugeririam indícios de contaminação de espécimes de peixes do Sítio Histórico e Patrimônio Cultural Kalunga.

Resultado semelhante foi encontrado em avaliação realizada em peixes consumidos pela comunidade indígena de Sai Cinza na reserva Munduruku, município de Jacareacanga, Estado do Pará, Brasil, área considerada de risco de contaminação pelo mercúrio utilizado na garimpagem $^{(170)}$. No referido estudo, apesar da proximidade física da comunidade com áreas de garimpo, não foram identificadas, entre as espécies não carnívoras, concentrações de mercúrio acima dos valores de referência preconizados na legislação brasileira, sendo a concentração média de $0,112 \mu \mathrm{gHg} / \mathrm{g}(\mathrm{DP}=0,036)$. 


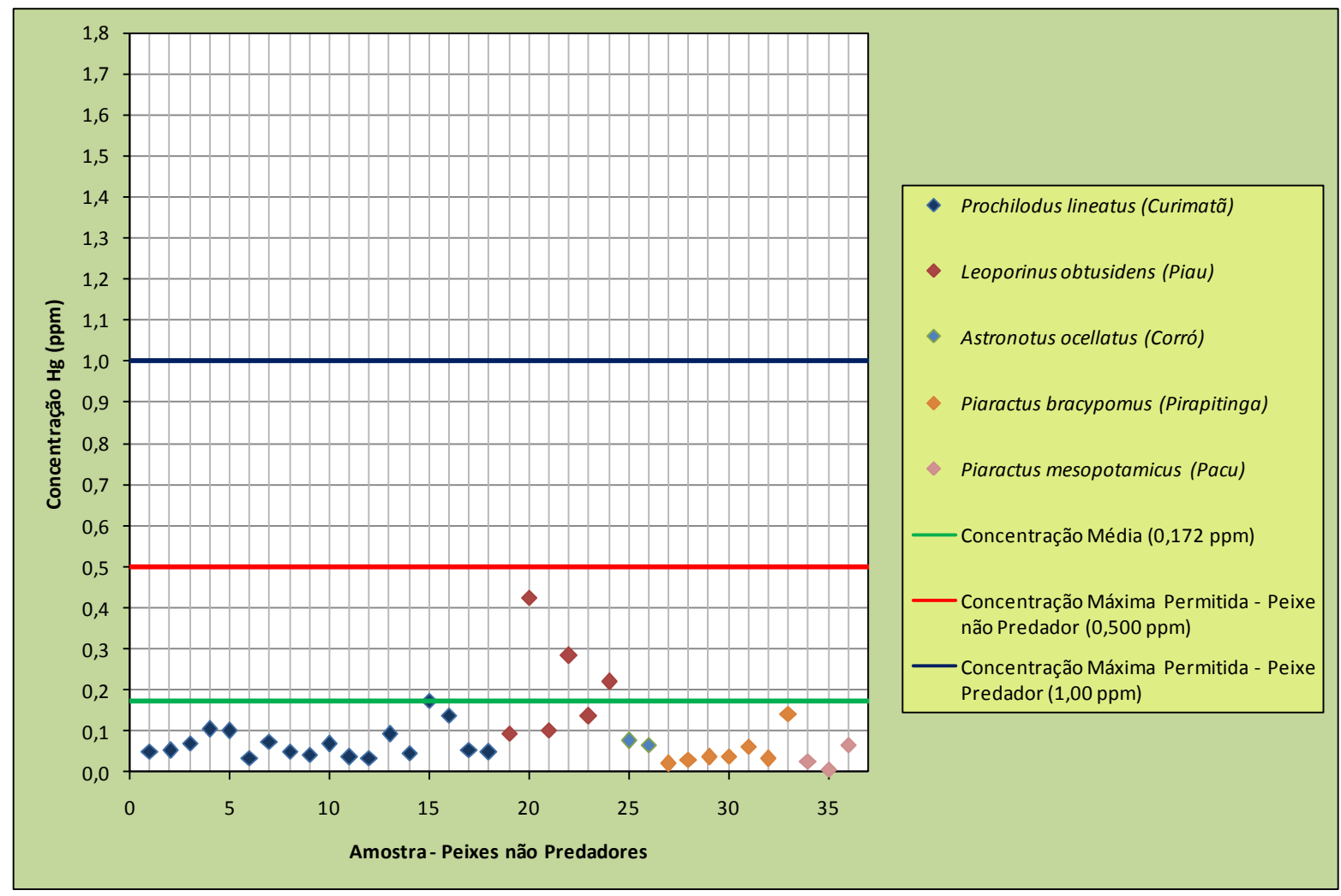

Figura 11 - Concentração média de Hg em peixes não predadores

Já com relação aos peixes predadores, conforme mostrado na Figura 11, observou-se que a concentração média de mercúrio foi de $0,681 \mu \mathrm{g} / \mathrm{g}(\mathrm{DP}=0,729)$, o que representa $68,1 \%$ da concentração máxima permitida para ingestão humana no Brasil.

O achado se difere do descrito em relação às espécies de peixes carnívoras pertencentes à bacia do Rio Madeira, um dos principais afluentes do Rio Amazonas. A localidade se singulariza por ter sido a segunda mais importante área produtora de ouro de garimpo da região amazônica durante mais de duas décadas. Sobre os peixes avaliados desta região, foi verificado, em estudo bibliográfico retrospectivo, que as espécies carnívoras vêm apresentando elevadas concentrações de $\mathrm{Hg}$ em seus tecidos, atingindo valores, para algumas espécies, superiores ao sugerido para a ingestão pela $\mathrm{OMS}^{(242)}$.

Sobre os resultados, destaca-se ainda que, entre as espécies de hábito alimentar piscívoro ou predador, as faixas de concentração de mercúrio variaram de 0,226 a 0,231 $\mu \mathrm{gHg} / \mathrm{g}$ para a bicuda (Boulengerella maculata); de 0,137 a 0,254 a $\mu \mathrm{gHg} / \mathrm{g}$ para a piranhanegra (Serrasalmus rhombeus) e de 1,578 a 1,652 $\mu \mathrm{gHg} / \mathrm{g}$ para a cachorra-facão ou camoteira (Rhaphiodon vulpinus). 
Neste grupo de peixes carnívoros $(\mathrm{n}=6 ; 100 \%)$, dois espécimes $(33,33 \%)$ apresentaram concentrações médias que ultrapassaram o limite máximo permitido para ingestão de pescado predador na legislação brasileira vigente, ambos representantes da espécie cachorra-facão ou camoteira (Rhaphiodon vulpinus), cujos dados analíticos indicaram níveis de concentração de mercúrio igual a $1,661 \mu \mathrm{gHg} / \mathrm{g}$ e $1,577 \mu \mathrm{gHg} / \mathrm{g}$, respectivamente.

Sabe-se que várias agências internacionais de saúde pública determinam o risco de ingestão de metilmercúrio para a população geral. A U.S. EPA, reavaliando os dados de contaminação do Iraque, propôs uma redução da dose de referência oral para o nível de 0,1 ppm por dia ${ }^{(243)}$. Já a Agência de Registro de Substâncias Tóxicas e Doenças dos Estados Unidos da América propôs uma ingestão de 0,3 ppm por dia como nível de risco mínimo ${ }^{(244)}$.

As diferenças nas concentrações limite das diversas agências nacionais e internacionais advêm dos diferentes estudos nos quais são baseadas, dos fatores de incerteza considerados, individualmente pelas agências que efetuaram os respectivos estudos e também da média de consumo de peixe daquela população ${ }^{(245)}$.

No presente estudo, os teores de mercúrio encontrados nos exemplares de cachorrafacão, além de ultrapassar o valor de referência adotado como limite máximo permitido para a ingestão de pescados no Brasil, pela ANVISA de 1.000 ng.g ${ }^{-1}$ para espécies carnívoras ${ }^{(239)}$, se mostram acima do tolerado para consumo pela OMS em suas preconizações sobre os Valores de Ingestão Tolerável (IST) de mercúrio ${ }^{(246)}$.

As proposições da OMS foram baseadas em estudos epidemiológicos elaborados a partir dos acidentes ocorridos em Minamata, no Japão, e do envenenamento por ingestão de grãos contaminados com fungicida mercurial, no Iraque, apontando que as referências de concentração de $\mathrm{Hg}$ em relação à frequência de consumo de pescado são: Consumo diário até $0,3 \mu \mathrm{g} \cdot \mathrm{g}^{-1}$; Consumo eventual - entre 0,3 e $1,0 \mu \mathrm{g} \cdot \mathrm{g}^{-1}$; e Não deve ser consumido - Acima de $1,0 \mu \mathrm{g} \cdot \mathrm{g}^{-1}$.

Destaca-se que, apesar de existirem limites, como os acima definidos, a quantidade de mercúrio acumulada pelo homem a partir da ingestão de peixes varia em função da quantidade e da frequência com que o peixe é consumido e dos níveis de $\mathrm{Hg}$ presentes nesses peixes. Portanto, as concentrações no alimento são importantes, mas a frequência de consumo deste alimento também o é ${ }^{(245)}$. 
O exposto anteriormente evidencia a importância de que estudos sobre a temática intoxicação alimentar por mercúrio considerem o contexto específico dos grupos populacionais em questão, por meio da associação entre os limites de concentração de $\mathrm{Hg}$ em peixes e a taxa de consumo deste alimento pela população em referência, como o que acontece com o valor de referência de $0,5 \mu \mathrm{g} \cdot \mathrm{g}^{-1}$ sugerido pela OMS, o qual tem aplicabilidade em um contexto de consumo de até $400 \mathrm{~g}$ de peixe por semana para indivíduos de até $60 \mathrm{~kg}$.

As populações com diferentes culturas e hábitos alimentares consumirão mais ou menos peixes tendo maior ou menor acumulação ${ }^{(245)}$. Em se tratando do Brasil, por exemplo, o padrão de ingesta de peixe varia significativamente de acordo com a região do país, o nível socioeconômico e os hábitos individuais de cada grupo populacional. Para ilustrar o proposto, pode-se citar o Amazonas, estado brasileiro onde se encontra a maior taxa de consumo de peixe por ano. Uma pessoa chega a ingerir $155 \mathrm{~g}$ de peixe por dia e no ano o consumo individual neste estado chega a $55 \mathrm{~kg}$, enquanto a média do Brasil é de $7 \mathrm{~kg}^{(247)}$.

Deste modo, observa-se que generalizações descontextualizadas podem incorrer no risco de estimar valores baixos demais para comunidades que consomem pouco peixe ou, ainda, altos demais para garantir a proteção de consumidores frequentes ${ }^{(248)}$.

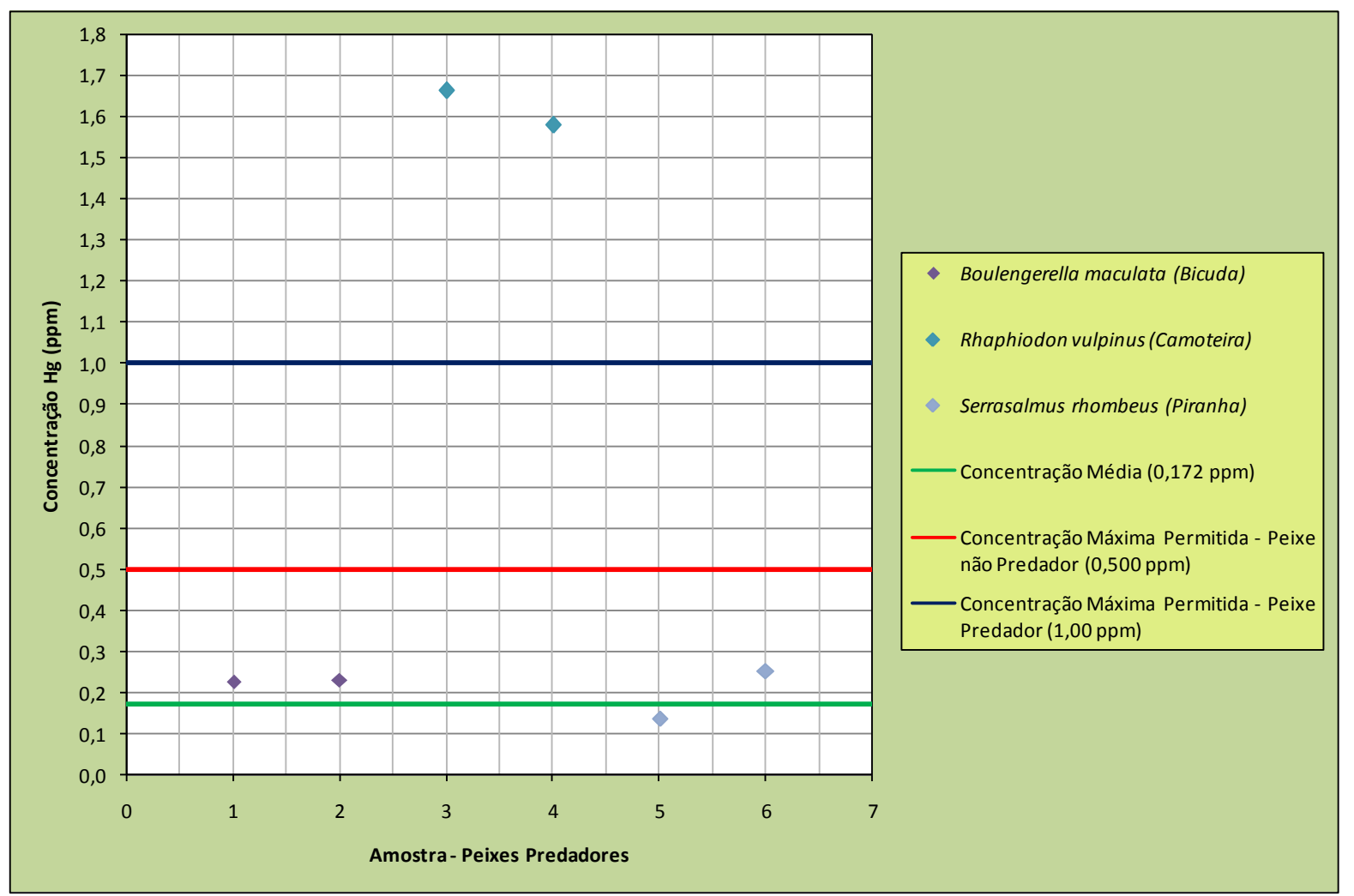

Figura 12 - Concentração média de Hg em peixes predadores 
Os dados de biometria dos peixes subsidiaram os resultados da análise de correlação entre a concentração de mercúrio o tamanho e o peso dos espécimes estudados. Ambas as correlações (concentração de mercúrio com tamanho e peso) para o nível de significância utilizado de 0,01 .

De tal modo, foi possível constatar que as variações de peso tiveram uma relação positiva com as concentrações de mercúrio total $(\mathrm{THg})$. O coeficiente correlação de Pearson entre o mercúrio total e o peso dos peixes foi de $\rho=0,941$, tendo, desta forma, sido verificada forte associação estatisticamente significativa $(p \leq 0,001)$ entre estes parâmetros da população de peixes - níveis de contaminação e o peso (Figura 13).

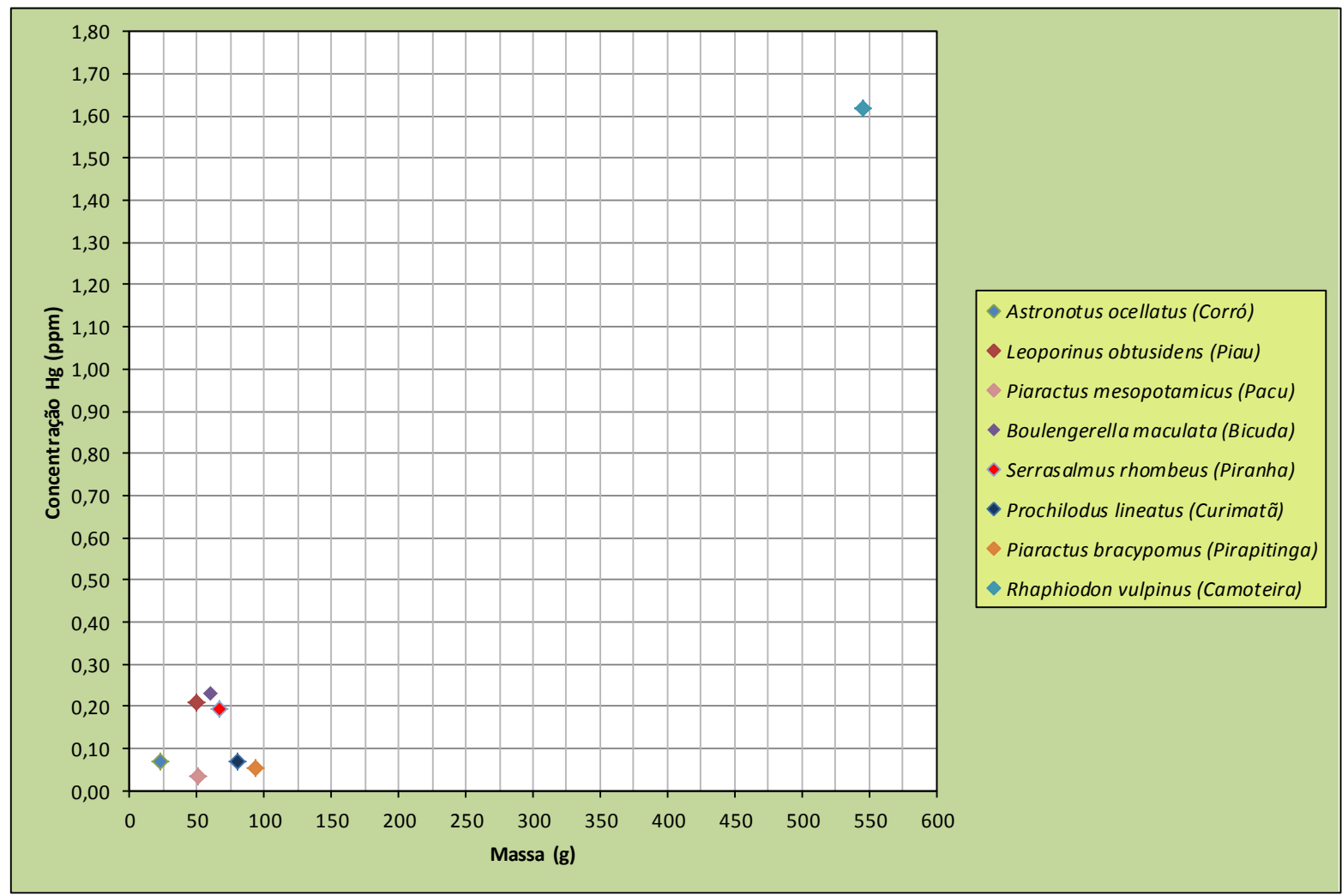

Figura 13 - Correlação massa e concentração de mercúrio em peixes

Já com respeito ao resultado da análise correlacional entre o teor de mercúrio encontrado no tecido e o comprimento dos peixes, também foi detectada associação positiva entre estes parâmetros (Figura 14). O coeficiente de Pearson entre o mercúrio total e o comprimento total dos espécimes foi de $\rho=0,893$, tendo, portanto, sido detectado forte associação com significado estatístico $(\mathrm{p}=0,000)$.

Assim, a partir dos dados morfométricos, constatou-se que as variações de massa e comprimento tiveram uma relação positiva com as concentrações de $\mathrm{THg}$, podendo indicar 
existência da relação do acúmulo do metal com o crescimento dos peixes analisados. Este achado é similar ao verificado por autores como Mendez, Giudice, Pereira, Inocente e Medina $^{(249)}$, que descreveram forte correlação entre as concentrações de $\mathrm{THg}$ e o comprimento de peixes da espécie Xiphias gladius.

Entretanto, se faz relevante destacar que, para se relacionar, com segurança, tamanho e teor de $\mathrm{Hg}$, é indispensável o desenvolvimento de estudo com maior detalhamento, incluindo, por exemplo, um maior número de amostras da mesma espécie para o mesmo tamanho, e com distribuição dos exemplares por idade (curva de idade x crescimento), uma vez que, em geral, para cada espécie, parâmetros como peso e tamanho estão diretamente ligados à idade do organismo.

As informações sobre o peso, o tamanho e os hábitos alimentares das espécies são importantes na avaliação dos processos de bioacumulação do mercúrio ${ }^{(165)}$. A permanência do peixe em águas com a presença do $\mathrm{Hg}$ enquanto poluente, principalmente em sua forma orgânica, reflete, portanto, a maior exposição destes animais ao metal, acarretando, consequentemente, maior possibilidade de acúmulo gradativo ao longo da vida do animal.

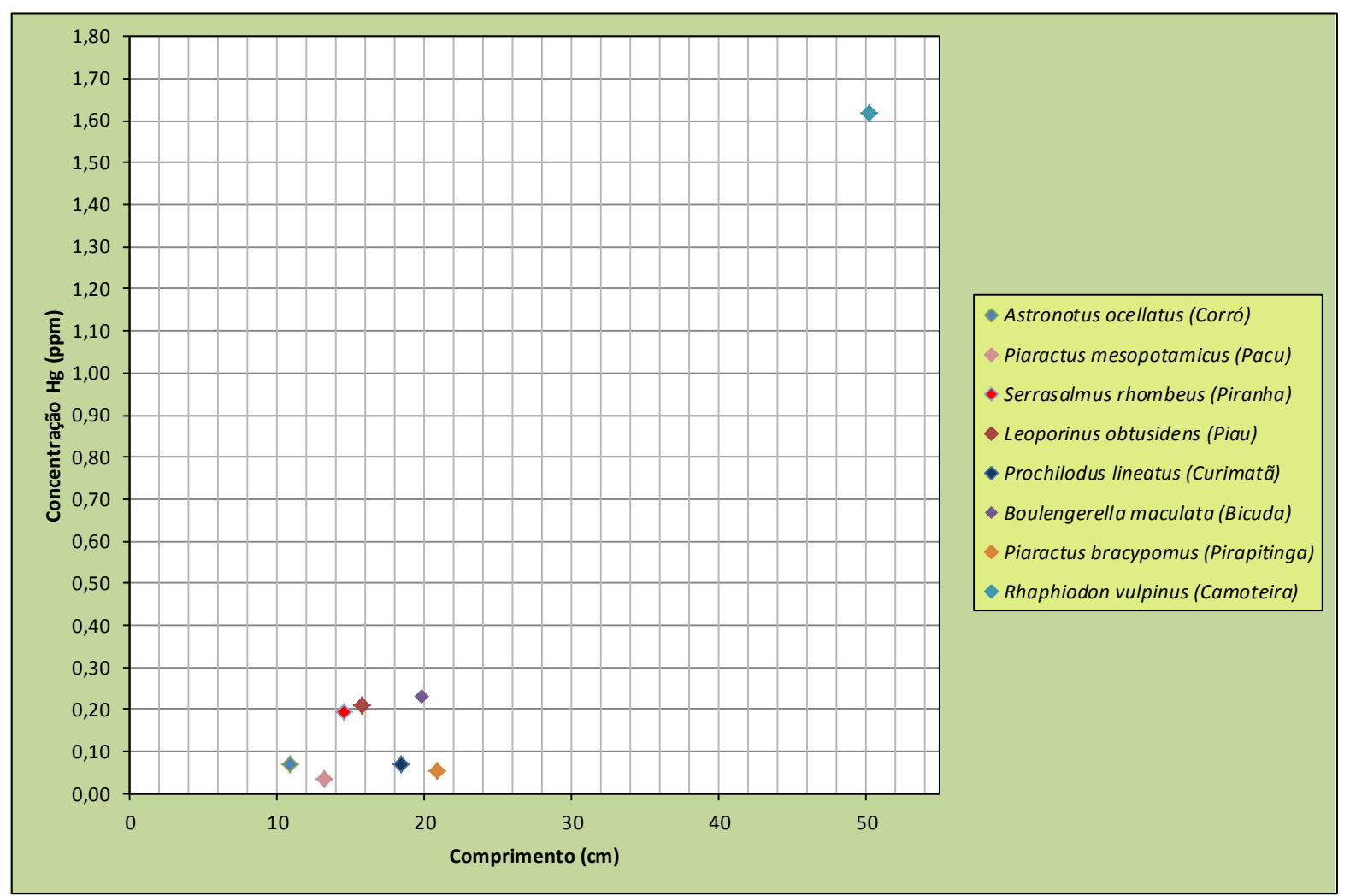

Figura 14 - Correlação comprimento e concentração de mercúrio em peixes 
No estudo, verificou-se, de modo geral, a predominância de correlação forte entre essas variáveis e os níveis de mercúrio em tecido muscular nos espécimes avaliados. Tal resultado é corroborado por Azevedo e Chasin ${ }^{(250)}$ ao proporem que cada espécie apresenta um caráter de absorção e acumulação de mercúrio diferenciado, de acordo com fatores biológicos específicos, tais como: tamanho e peso do organismo, hábito alimentar, idade (estágio de desenvolvimento), taxa de excreção, teor lipídico (organismos com alto teor lipídico tendem a acumular mais substâncias lipossolúveis), comportamento (territorialista ou migratório) e o metabolismo (capacidade de biotransformação dos compostos com o objetivo de gerar produtos hidrossolúveis, mais fáceis de serem excretados).

Quando conhecidas, tais informações podem ser úteis no contexto da saúde pública, permitindo que os consumidores, incluindo em áreas remotas como as habitadas pelos quilombolas Kalungas, selecionem peixes de espécie e tamanho com menores teores de mercúrio total $^{(249)}$.

Com o objetivo de complementar os achados acerca da presença de mercúrio orgânico no tecido de peixes e com vistas ao incremento na abordagem dos aspectos correlatos às condições ambientais e de saúde vivenciadas pelos Kalungas, fez-se relevante analisar, também, os níveis de mercúrio no cabelo desses moradores. A justificativa para tal direcionamento consiste no fato de que, durante a etapa de levantamento dos principais problemas de saúde identificados pela comunidade, houve citações acerca da presença de atividade garimpeira não regulamentada na localidade, sendo este enfoque da investigação demandada pelos próprios moradores.

Sobre a incorporação do elemento-traço $\mathrm{Hg}$ ao cabelo humano, destaca-se que, após um período médio de 72 dias, o mercúrio absorvido pelo organismo deixa de circular na corrente sanguínea, e a fração não eliminada é depositada nos tecidos e órgãos do corpo humano. Contudo, na fase de presença deste metal no sangue, o mercúrio é incorporado ao cabelo em formação, e sua concentração não mais se modifica ${ }^{(60)}$. A porção do cabelo formada no período de exposição concentra em determinado ponto as quantidades de mercúrio proporcionais aos níveis sanguíneos deste metal, e, à medida que o cabelo vai crescendo, este ponto vai se afastando da raiz, sendo a análise longitudinal do cabelo capaz de refletir a história da poluição ambiental ${ }^{(201)}$. 
Assim, dentre os vários tipos de amostras biológicas, o cabelo tem sido reconhecido como acumulador de metais pesados em suas fibras, inclusive o mercúrio, caracterizando-se em bom biomarcador da exposição crônica de indivíduos a esse metal pesado ${ }^{(60)}$. Ele é particularmente empregado de avaliação da exposição ambiental da população geral, representada por pessoas sem histórico de contato profissional com o $\mathrm{Hg}$, sendo útil para o levantamento do grau de exposição ao $\mathrm{MeHg}$ veiculado por alimentos contaminados ${ }^{(251)}$.

No total, foram analisadas amostras de cabelo de 58 indivíduos utilizando-se a espectrometria de absorção atômica com vapor frio. As mulheres foram responsáveis pela composição de 60,3\% ( $n=35)$ do total da amostra e os homens por 39,7\% ( $n=23)$. Neste grupo, as idades variaram de 18 a 80 anos. Na Figura 15, são mostrados os valores encontrados para o teor de $\mathrm{Hg}$ presente em cada uma das amostras de cabelos dos moradores Kalungas do estudo.

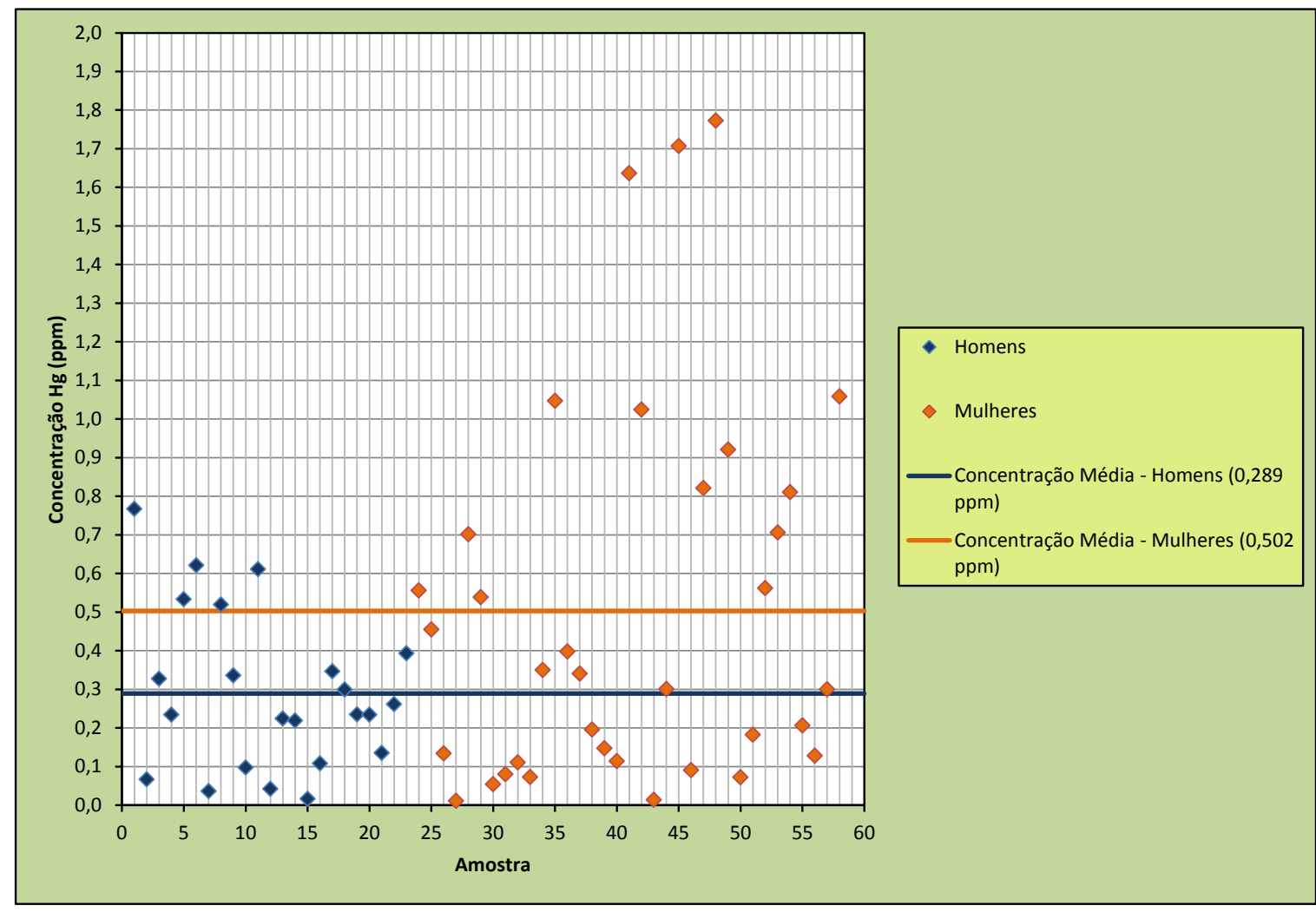

Figura 15 - Frequência das concentrações de mercúrio em cabelo humano

A partir dos dados analíticos, pôde-se constatar que os níveis de mercúrio total nos cabelos dos moradores Kalungas variaram entre 0,010 e 1,771 $\mu \mathrm{g} / \mathrm{g}$ (microgramas de mercúrio por grama de cabelo analisado). O nível de concentração média de mercúrio foi de $0,418 \mu \mathrm{g} / \mathrm{g}$, sendo a mediana igual a 0,299, com desvio padrão de 0,414 e a variância igual a 0,172 . 
Em estudo realizado com avaliação de amostras de cabelo de um grupo controle, composto por moradores de São Paulo sem qualquer tipo de exposição ambiental, foi encontrado de mediana de $1 \mathrm{mg} / \mathrm{kg}$ para $\mathrm{Hg}^{(252)}$, lembrando que a OMS estabelece os valores de $6,0 \mu \mathrm{g} / \mathrm{g}$ para pessoas expostas e $2,0 \mu \mathrm{g} / \mathrm{g}$ como o máximo tolerável para a população adulta não exposta a ambientes impactados pelo mercúrio ${ }^{(253)}$.

Os achados mostraram que não houve, entre os moradores Kalungas do estudo, valores de concentração de mercúrio total nos cabelos acima do valor de referência, sendo a concentração média encontrada compatível com o descrito pela Organização Mundial da Saúde para populações não expostas ${ }^{(253)}$.

Entre os moradores pesquisados do sexo feminino, o teor de mercúrio nos cabelos variou de 0,010 a $1,772 \mu \mathrm{g} / \mathrm{g}$, com média de concentração igual a $0,503 \mu \mathrm{gHg} / \mathrm{g}$ e desvio padrão de 0,492. Os valores da mediana e da variância foram 0,340 e 0,242, respectivamente. Já em relação aos representantes do sexo masculino, o intervalo de concentração variou entre 0,015 e $0,767 \mu \mathrm{gHg} / \mathrm{g}$, com valor médio de $0,289 \mu \mathrm{g} / \mathrm{g}$ e desvio padrão de 0,206 . Os valores da mediana e da variância encontrados foram 0,234 e 0,042, respectivamente. Verificou-se, assim, que a concentração média capilar de mercúrio em mulheres foi maior que em homens $(0,503 \mu \mathrm{gHg} / \mathrm{g}$ e $0,289 \mu \mathrm{g} / \mathrm{g})$; entretanto, o teste de associação do qui-quadrado mostrou que tal diferença não apresentou significado estatístico, sendo p $>0,05$.

Resultado similar foi descrito em estudo envolvendo crianças residentes da região Sudeste do Brasil, no qual, à semelhança dos presentes resultados, não encontraram diferença estatística entre os teores médios de mercúrio em cabelo com relação ao sexo ${ }^{(254)}$.

Na Tabela 11, são mostrados dados sobre a concentração de mercúrio em cabelos dos quilombolas segundo município de moradia.

Tabela 11 - Concentração de mercúrio no cabelo de quilombolas segundo município, em 2012

\begin{tabular}{l|c|c|c|c}
\hline \multirow{2}{*}{\multicolumn{1}{c}{ Variáveis }} & \multicolumn{4}{c}{ Municípios } \\
\cline { 2 - 5 } & $\begin{array}{c}\text { Cavalcante } \\
\mathrm{n}(\%)\end{array}$ & $\begin{array}{c}\text { Teresina de } \\
\text { Goiás } \\
\mathrm{n}(\%)\end{array}$ & $\begin{array}{c}\text { Monte } \\
\text { Alegre } \\
\mathrm{n}(\%)\end{array}$ & $\begin{array}{c}\text { Total } \\
\mathrm{n}(\%)\end{array}$ \\
\hline $\begin{array}{l}\text { Concentração de Mercúrio no Cabelo }{ }^{(*)} \\
\text { Alto }\end{array}$ & $4(40,0)$ & $9(26,5)$ & $8(57,1)$ & $19(32,8)$ \\
Baixo & $6(60,0)$ & $25(73,5)$ & $6(42,9)$ & $39(67,2)$ \\
\hline
\end{tabular}

(*) A classificação 'Alto' ou 'Baixo' tem como referência a comparação dos valores encontrados para cada amostra de cabelo humano com o valor médio do teor de mercúrio encontrado no grupo de moradores Kalungas estudado, sendo classificado enquanto 'alto' os valores obtidos acima da média do valor da concentração de mercúrio encontrado para o grupo e ‘baixo’ os resultados menores que este teor médio. 
Destaca-se que, de acordo com os valores das concentrações encontradas na amostra de cabelo de cada morador, realizou-se agrupamento quanto ao comparativo dos resultados em 'alto' e 'baixo'. Destarte, identificou-se que 67,2\% (n=39) das amostras de cabelo humano estudadas puderam ser caracterizadas como 'baixa' concentração de mercúrio, ao passo que $32,8 \%(n=19)$ encaixaram-se no grupo descrito como 'alta' concentrações de mercúrio, ou seja, com concentrações de mercúrio acima do teor médio encontrado para a amostra $(0,413$ $\mu \mathrm{gHg} / \mathrm{g})$, conforme descrito na Figura 16.

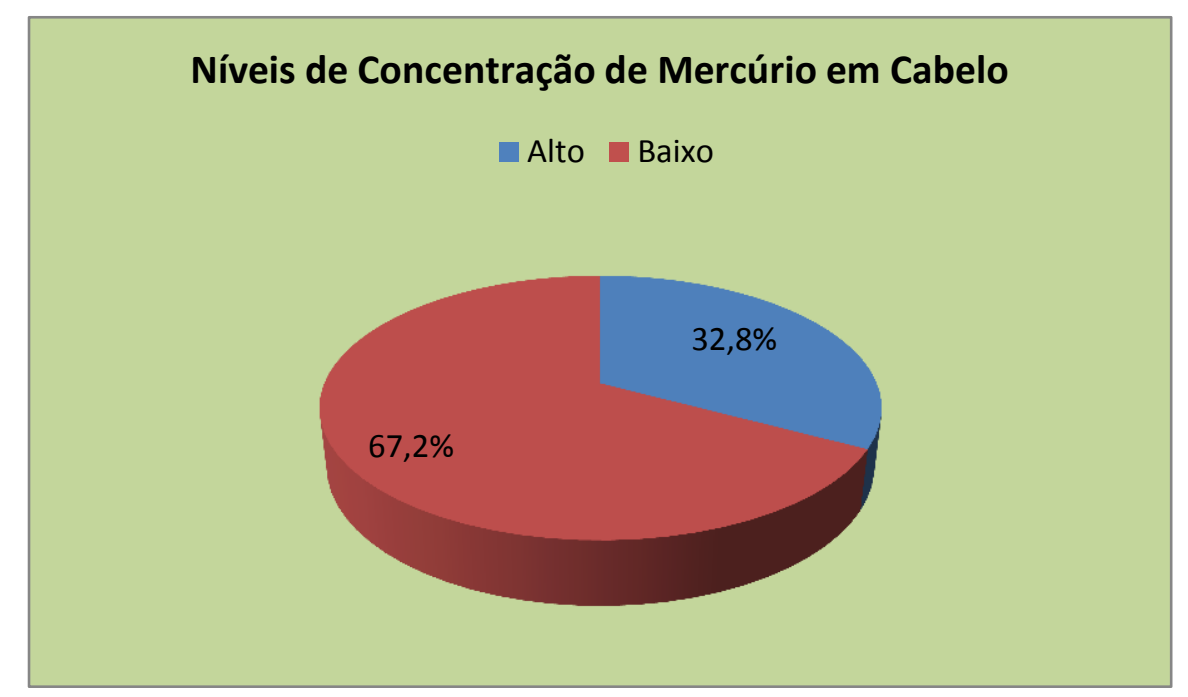

Figura 16 - Níveis de concentração de Hg em cabelos de quilombolas Kalungas

Entre os Kalungas do município de Cavalcante, 10 moradores (17,24\%) compuseram a amostra para a análise de mercúrio total em cabelos, em Monte Alegre, 14 (24,14\%) e em Teresina de Goiás, 34 (58,62\%). Monte Alegre foi o município que apresentou a maior proporção $(\mathrm{n}=8 ; 51,7 \%)$ de moradores com alto teor de mercúrio nos cabelos, seguido de Cavalcante $(n=4 ; 40,0 \%)$ e Teresina de Goiás $(n=9 ; 26,5 \%)$. De acordo com o teste do quiquadrado não houve significância estatística na associação entre as variáveis: município de moradia e concentração do metal pesado mercúrio no cabelo humano, sendo p=0,077.

Na Tabela 12, são mostradas algumas características socioeconômicas de moradores remanescentes de quilombos segundo o teor de mercúrio encontrado nas amostras de cabelo analisadas. 
Tabela 12 - Aspectos socioeconômicos e concentração de mercúrio no cabelo de moradores do Sítio Histórico e Patrimônio Cultural Kalunga, em 2012

\begin{tabular}{l|cc}
\hline \multirow{2}{*}{ Características } & Concentração de mercúrio no cabelo \\
\cline { 2 - 3 } & $\begin{array}{c}\text { Alto } \\
\mathrm{n}(\%)\end{array}$ & $\begin{array}{c}\text { Baixo } \\
\mathrm{n}(\%)\end{array}$ \\
\hline Sexo & & $18(78,3)$ \\
$\quad$ Masculino & $5(21,7)$ & $21(60,0)$ \\
$\quad$ Feminino & $14(40,0)$ & \\
Faixa Etária & & $22(71,0)$ \\
$\quad$ Entre 18 - 50 anos & $9(29,0)$ & $17(63,0)$ \\
51 anos ou mais & $10(7,0)$ & $12(75,0)$ \\
Escolaridade & & $27(64,3)$ \\
$\quad$ Não Alfabetizado & $4(25,0)$ & $17(77,3)$ \\
Alfabetizado & $15(35,7)$ & $16(57,1)$ \\
Ocupação & & $6(75,0)$ \\
$\quad$ Lavrador & $5(22,7)$ & \\
Dona de casa & $12(42,9)$ & $36(70,6)$ \\
Outras atividades & $2(25,0)$ & $3(42,9)$ \\
Consumo de peixe na alimentação & & $17(77,3)$ \\
Sim & $15(29,4)$ & $16(59,3)$ \\
Não & $4(57,1)$ & $6(66,7)$ \\
Principal atividade econômica & & \\
Agricultura & $5(22,7)$ & $11(40,7)$ \\
Pecuária & $3(33,3)$ & \\
Outras (turismo, artesanato, etc.) & & \\
\hline
\end{tabular}

A partir dos achados mostrados na Tabela 12, pôde-se afirmar que as proporções encontradas com relação às variáveis sexo e concentração de mercúrio foram similares ao encontrado na população geral do estudo. Assim, no grupo com as maiores taxas de concentração de mercúrio, 21,7\% (n=5) são homens e 78,3\% (n=18) são mulheres. Já o grupo com as concentrações mais baixas de mercúrio no cabelo foi formado por 40,0\% de homens $(n=21)$ e $60,0 \%$ de mulheres $(n=14)$. De acordo com o teste do qui-quadrado não houve significado estatístico na associação das variáveis supramencionadas (sexo e teor de mercúrio no cabelo), sendo $\mathrm{p}=2,101$.

Apesar da referência de que o conteúdo de mercúrio em cabelos humanos varia conforme a faixa etária de crianças, para jovens e $\operatorname{adultos}^{(255)}$, na pesquisa, a faixa etária não se caracterizou em fator diferenciador quando associado a variável Concentração de Mercúrio. O achado foi evidenciado pela inobservância de significado estatístico nesta associação, sendo $\mathrm{p}=0,420$. Os resultados mostraram, ainda, que $29,0 \%$ dos moradores entre 18 e 50 anos $(n=9)$ apresentando valor para a concentração de mercúrio no cabelo agrupado na categoria valores mais altos e 71,0\% $(\mathrm{n}=22)$ na categoria valores mais baixos de $\mathrm{Hg}$. Para os indivíduos com 51 anos ou mais, os achados foram 37,0\% (n=10) e 63,0\% (n=17), respectivamente. 
Com relação a variável escolaridade, entre os moradores não alfabetizados, 25,0\% $(\mathrm{n}=4)$ apresentou concentrações de mercúrio no cabelo acima do valor médio encontrado para o grupo em estudo, sendo incluídos na categoria concentração de mercúrio mais alta. Por outro lado, 75,0\% $(\mathrm{n}=12)$ apresentaram baixo teor de mercúrio nos cabelos. Dentre os Kalungas alfabetizados, as proporções foram de $35,7 \%(n=15)$ para o grupo com as menores concentrações e 64,3\% (n=27) para indivíduos classificados como pertencentes ao grupo das concentrações mais altas de mercúrio. A variável não foi estatisticamente significativa (teste qui-quadrado: $\mathrm{p}=0,604)$.

Não houve significância estatística nas diferenças proporcionais encontradas na associação entre as variáveis: ocupação e concentração de mercúrio no cabelo (teste quiquadrado: $\mathrm{p}=2,520)$. Entre os Kalungas que se declararam lavradores, em 22,7\% $(\mathrm{n}=5)$ foi encontrado teor de mercúrio acima do valor médio local (alta concentração de $\mathrm{Hg}$ ), enquanto $77,3 \%(n=17)$ apresentou baixa concentração deste metal pesado nos cabelos. Entre as donas de casas as proporções entre os grupos com alta e baixa concentração de mercúrio foi 42,9\% $(n=12)$ e $57,1 \%(n=16)$, respectivamente. Entre os moradores que referiram outras ocupações, a proporção encontrada acima do teor médio local foi de $25,0 \%(\mathrm{n}=2)$ e abaixo de $75,0 \%$ $(\mathrm{n}=6)$.

No que tange à inclusão do peixe no cardápio alimentar dos moradores, verificou-se que, dentre os que responderam afirmativamente ao item, 15 (29,4\%) tiveram resultado acima da média local para o teor de mercúrio no cabelo analisado. Por outro lado, em 36 indivíduos (70,6\%) foram encontrados valores abaixo de $0,413 \mu \mathrm{g} / \mathrm{g}$, (teor médio de mercúrio encontrado para a população estudada) categorizados enquanto baixa concentração de mercúrio, apesar da referência ao consumo com certa regularidade de peixe nas refeições. Entre os moradores que referiram não consumir peixe nas refeições, $57,1 \%(n=4)$ apresentaram alta concentração de mercúrio nos cabelos e 42,9\% (n=3) baixa. Neste estudo não foi encontrado significado estatístico na associação entre as variáveis consumo de peixe na alimentação e concentração de mercúrio no cabelo (teste qui-quadrado: $\mathrm{p}=2,149$ ).

Resultados similares foram encontrados com relação às concentrações médias de $\mathrm{Hg}$ em cabelos por situação de consumo de peixe e/ou organismos aquáticos de rios em Cubatão. Neste trabalho, os autores verificaram que o teor médio de mercúrio no cabelo de crianças consumidoras de produtos dos rios da região não difere estatisticamente do teor médio apresentado pelas crianças não consumidoras de organismos aquáticos de qualquer 
origem $^{(254)}$. Por outro lado, em estudo sobre a avaliação dos níveis de exposição ao mercúrio entre índios Pakaanóva, no Estado do Amazonas, os autores encontraram forte associação do padrão alimentar dependente do peixe enquanto fonte proteica com o aumento da exposição ao Hg identificada por meio da concentração capilar do metal pesado mais alta na população estudada ${ }^{(256)}$.

A associação entre as variáveis principal atividade econômica e concentração de mercúrio no cabelo possibilitou identificar o não estabelecimento de significado estatístico, sendo $\mathrm{p}=1,787$. Dentre os moradores que referiram a agricultura como atividade econômica responsável pelo sustento familiar, em cinco $(22,7 \%)$ indivíduos encontrou-se alto teor de mercúrio no cabelo e em 77,3\% (n=17) baixo nível de mercúrio nos cabelos de moradores. Já entre os moradores que referiram a pecuária como principal atividade econômica, as proporções encontradas foram de 40,7\% $(n=11)$ para os níveis mais altos e 59,3\% (n=16) para os mais baixos. Por último, em relação aos Kalungas que desenvolvem outros tipos de atividades econômicas, como turismo, artesanato, entre outros, encontrou-se uma proporção de 33,3\% (n=3) dos respondentes com teor de mercúrio no cabelo acima da média local, sendo considerado como pertencente ao grupo de concentração alta de mercúrio, e 66,7\% $(n=6)$ considerado com baixa concentração de mercúrio total nos cabelos.

Alguns autores destacam a importância de trabalhos relativos ao teor de $\mathrm{Hg}$ em cabelos de comunidades nacionais, principalmente aquelas localizadas fora do ecossistema amazônico, como no caso das comunidades quilombolas Kalungas ${ }^{(257)}$. Estas determinações de teor de mercúrio futuramente poderão contribuir para a elaboração e comparação do perfil da distribuição de $\mathrm{Hg}$ e MeHg no país, considerando a ampla diversidade de ecossistemas e padrões culturais e socioeconômicos, visto que a frequência com que as populações consomem pescado e a espécie consumida recebe influência desses aspectos ${ }^{(258)}$.

\subsubsection{Caracterização das condições de saúde de moradores Kalungas}

O direito à saúde é uma das premissas básicas do SUS, explicitado no texto que constituiu a OMS, em 22de julho de 1946, o qual foi subscrito por 61 países, dentre eles, o Brasil. Na ocasião, pela primeira vez, a saúde passou a ser entendida como "um estado de completo bem-estar físico, mental e social e não somente a ausência de afecções ou enfermidades", e, ainda, como "a fruição do nível máximo de saúde que se possa adquirir", 
sendo "um dos direitos fundamentais de todo o ser humano sem distinção de 'raça', religião, ideologia política e condição econômica e social”(259).

Contudo, o pleno acesso aos serviços públicos de saúde e de qualidade, para toda a população brasileira, ainda é uma conquista longe de se efetivar na prática. Isto, pois, se torna mais evidente ao se enfocar populações historicamente marginalizadas quanto ao acesso a políticas públicas, como é o caso das comunidades quilombolas, sendo a visão de vulnerabilidade social, usualmente, referida nos quilombos em relação à saúde e à doença ${ }^{(54)}$.

Assim, levando-se em conta os diferentes fatores que entrariam na composição da saúde destes grupos, observou-se que (Tabela 13), apesar das condições sanitárias insuficientes destas populações e da ausência de serviços de saúde locais, a maioria dos moradores Kalungas entrevistados $(n=191 ; 95,0 \%)$ se autorefere saudável. Outra característica importante dessa comunidade é o fato de que 63,7\% (n=128) dos moradores estudados relatam não fazer uso contínuo de medicação de uso sistêmico e $100 \%$ (n=201) referiu já ter usado medicações alternativas ao tratamento alopático como chás, garrafadas e preparos em eventuais agravos e problemas em saúde. Realidade semelhante também pode ser encontrada em outras comunidades quilombolas, nas quais se observa o uso do conhecimento ancestral, como a manipulação de plantas encontradas na própria comunidade na produção de medicamentos, unguentos, chás, tinturas, sucos e garrafadas utilizados no tratamento de diferentes agravos ${ }^{(90,260,261)}$.

Entre as atividades de lazer foram citadas com maior frequência aquelas realizadas em espaços coletivos $(n=132 ; 65,7 \%)$, como conversar com vizinhos $(n=63 ; 31,3 \%)$, jogar futebol $(\mathrm{n}=27 ; 13,4 \%)$, passear nas cachoeiras locais $(\mathrm{n}=11 ; 5,5 \%)$ ou participar de festas e rezas tradicionais da cultura Kalunga $(n=20 ; 10,0 \%)$. Apenas 5,5\% $(n=11)$ dos participantes relataram realizar atividades no próprio domicílio (assistir TV, ouvir rádio, dentre outros); $34,3 \%(n=69)$ negaram a prática de atividades de lazer. Em estudo realizado na comunidade quilombola de Santarém, estado do Amazonas, também foi observada uma predominância na utilização do espaço comum para as atividades de lazer. De modo semelhante ao descrito pelos moradores Kalungas, os quilombolas de Santarém também referenciaram enquanto principais espaços de lazer utilizados pela comunidade o campo de futebol, o Rio Amazonas e os locais utilizados para festejos, como a sede do clube local e o barracão comunitário ${ }^{(261)}$. 
Tabela 13 - Aspectos relacionados às condições de saúde dos Kalungas, em 2012

\begin{tabular}{|c|c|c|c|c|}
\hline \multirow[b]{2}{*}{ Variáveis } & \multicolumn{4}{|c|}{ Municípios } \\
\hline & $\begin{array}{c}\text { Cavalcante } \\
\mathrm{n}(\%)\end{array}$ & $\begin{array}{c}\text { Teresina de } \\
\text { Goiás } \\
\mathrm{n}(\%)\end{array}$ & $\begin{array}{c}\text { Monte } \\
\text { Alegre } \\
\mathrm{n}(\%)\end{array}$ & $\begin{array}{l}\text { Total } \\
\mathrm{n}(\%)\end{array}$ \\
\hline \multicolumn{5}{|l|}{ Considera-se saudável } \\
\hline Sim & $29(93,5)$ & $68(95,8)$ & $94(95,0)$ & $191(95,0)$ \\
\hline Não & $2(6,5)$ & $3(4,2)$ & $5(5,0)$ & $10(5,0)$ \\
\hline \multicolumn{5}{|l|}{ Usa medicação contínua } \\
\hline Sim & $3(9,7)$ & $17(24,0)$ & $23(23,2)$ & $43(21,4)$ \\
\hline Não & $28(90,3)$ & $54(76,0)$ & $76(76,8)$ & $158(78,6)$ \\
\hline \multicolumn{5}{|l|}{ Pratica atividades de lazer } \\
\hline Sim & $27(87,1)$ & $39(54,9)$ & $66(66,7)$ & $132(65,7)$ \\
\hline Não & $4(12,9)$ & $32(45,1)$ & $33(33,3)$ & $69(34,3)$ \\
\hline \multicolumn{5}{|c|}{ Utiliza apenas a rede pública de saúde } \\
\hline Sim & $31(100,0)$ & $70(98,6)$ & $99(100,0)$ & $200(99,5)$ \\
\hline Não & - & $1(1,4)$ & - & $1(0,5)$ \\
\hline \multicolumn{5}{|c|}{$\begin{array}{l}\text { Ao adoecer busca atendimento } \\
\text { profissional }\end{array}$} \\
\hline Sim & $30(96,8)$ & $60(84,5)$ & $73(73,7)$ & $163(81,1)$ \\
\hline Não & $1(3,2)$ & $11(15,5)$ & $26(26,3)$ & $38(18,9)$ \\
\hline \multicolumn{5}{|c|}{ Qual o profissional procurado } \\
\hline Agente de saúde & $11(35,5)$ & $58(81,7)$ & $80(80,8)$ & $149(74,1)$ \\
\hline Médico & - & $13(18,3)$ & $7(7,1))$ & $20(10,0)$ \\
\hline Enfermagem & $20(64,5)$ & - & $12(12,1)$ & $32(16,0)$ \\
\hline Outros & - & - & - & - \\
\hline \multicolumn{5}{|c|}{$\begin{array}{l}\text { Local procurado para assistência em } \\
\text { saúde }\end{array}$} \\
\hline ESF & $1(3,2)$ & $18(25,4)$ & - & $19(9,5)$ \\
\hline Posto de saúde & $30(96,8)$ & $44(62,0)$ & $95(96,0)$ & $169(84,1)$ \\
\hline Hospital & - & $9(12,7)$ & $4(4,0)$ & $13(6,4)$ \\
\hline \multicolumn{5}{|c|}{ Local de aquisição de medicamentos } \\
\hline Posto de saúde & $25(80,7)$ & $52(73,2)$ & $81(81,8)$ & $158(78,6)$ \\
\hline Farmácia & $5(16,1)$ & $12(16,9)$ & $15(15,2)$ & $32(15,9)$ \\
\hline Outros & $1(3,2)$ & $7(9,9)$ & $3(3,0)$ & $11(5,5)$ \\
\hline \multicolumn{5}{|l|}{ Tabagista } \\
\hline Sim & $5(16,1)$ & $20(28,2)$ & $29(29,3)$ & $54(26,9)$ \\
\hline Não & $26(83,9)$ & $51(71,8)$ & $70(70,7)$ & $147(73,1)$ \\
\hline \multicolumn{5}{|l|}{ Etilista } \\
\hline Sim & $10(32,3)$ & $30(42,3)$ & $23(23,2)$ & $63(31,3)$ \\
\hline Não & $21(67,7)$ & $41(57,7)$ & $76(76,8)$ & $138(68,7)$ \\
\hline
\end{tabular}

Ainda sobre os diferentes fatores capazes interferir na condição de saúde deste grupo específico, observa-se que a população Kalunga pode apresentar certa vulnerabilidade decorrente da exposição à precariedade nas condições higiênico-sanitárias e das dificuldades existentes frente à garantia do direito de acesso e atenção em saúde. Dessa forma, 84,6\% $(\mathrm{n}=170)$ da população Kalunga refere a presença de unidade de saúde, as quais são geralmente postos que ficam localizados fora da comunidade onde residem.

Destes, $42,9 \%$ ( $\mathrm{n}=73$ ) referem que a distância entre o local de moradia e a unidade de saúde mais próxima é superior a 71 quilômetros. A situação descrita é vivenciada em outros 
vários grupos de quilombos em nosso país ${ }^{(54)}$, como, por exemplo, os remanescentes de quilombos do Vale do Ribeira no Sudoeste de São Paulo, região caracterizada pela ausência de serviços de saúde locais, fazendo com que, ao surgirem doenças, os seus habitantes sejam obrigados a percorrer grandes distâncias em busca de ajuda, uma vez que as equipes de saúde da família que atendem a comunidade nem sempre são acessíveis, pois estão baseadas na sede do município cuja distância varia entre $10 \mathrm{~km}$ e $60 \mathrm{~km}$, a depender do lugarejo de residência $^{(262)}$.

A população da comunidade quilombola Kalunga depende exclusivamente do SUS na busca de assistência. Dentre os indivíduos entrevistados, a quase totalidade (n=200;99,5\%) declarou a utilização exclusiva da rede pública de saúde, enquanto $0,5 \%(\mathrm{n}=1)$ declarou que também utiliza os serviços de saúde particulares quando não consegue atendimento junto à rede pública. $\mathrm{O}$ resultado descrito é semelhante ao que ocorre no remanescente de quilombo Boqueirão, situado no estado da Bahia, no qual a maior proporção dos moradores $(95,5 \%)$ refere a utilização da rede pública do Sistema Único de Saúde, dos quais, 10,5\% também mencionaram a utilização da rede complementar do SUS pagando por serviços particulares $^{(220)}$.

Foi verificado que, em geral, a população $(n=163 ; 81,1 \%)$, quando adoece, adota principalmente medidas provenientes do saber popular, como chás, preparos e orientações de rezadeiras ou raizeiros. Apenas $18,9 \%(n=38)$ dos quilombolas Kalungas entrevistados declararam buscar preferencialmente atendimento com profissionais de saúde. O observado na comunidade Kalunga, com relação à utilização de plantas consideradas pelo grupo como medicinais, também acontece na população do quilombo Sangrador, no estado do Maranhão.

Segundo estudo realizado com os quilombolas de Sangrador, há uma preferência entre os moradores da região pela utilização de práticas tradicionais baseadas no uso de plantas tidas como medicinais, sejam estas indicadas para afecções que têm correspondência na medicina oficial, assim como para doenças e estados de desconforto indicados pela população local, mas que não são reconhecidos pela medicina moderna, tais como "mau-olhado" e "quebranto".

Assim, os primeiros cuidados de saúde são realizados por meio de práticas alternativas e do uso de plantas, associadas ou não a produtos de origem animal. No referido estudo, foi descrito que a maioria dos quilombolas $(66,7 \%)$ tem preferência pelos chamados "remédios 
do mato", enquanto $25,7 \%$ dos entrevistados de ambos os sexos utilizam tanto plantas quanto fármacos industrializados na busca de resultados mais rápidos nos processos de cura, e apenas 7,6\% dos informantes afirmam utilizar exclusivamente fármacos industrializados, sob a justificativa de estes possuírem maior eficácia curativa, o que pode trazer menos desconforto aos enfermos ${ }^{(263)}$.

Com relação à categoria profissional apontada como responsável pelo atendimento das principais demandas em saúde, $74,1 \%(\mathrm{n}=149)$ da população Kalunga mencionou os agentes comunitários, 16,0\% ( $\mathrm{n}=32)$ enfermeiros, técnicos ou auxiliares de enfermagem e 10,0\% $(n=20)$ o profissional médico. Não houve referências aos demais profissionais da saúde. Vieira e Monteiro ${ }^{(58)}$ corroboram com o proposto ao inferirem que, entre os Kalungas, o Agente Comunitário de Saúde (ACS) é quem se mantém responsável pelo acompanhamento do estado de saúde das famílias quilombolas. Na comunidade, de modo geral, a assistência à saúde é realizada pelas equipes da Estratégia Saúde da Família (ESF), contudo se evidencia certa precariedade nos serviços e um reduzido número de unidades, equipes e profissionais, especialmente médicos, dentistas e enfermeiros.

Quanto ao acesso a medicamentos e sua aquisição, a maioria dos entrevistados $(\mathrm{n}=158 ; 78,6 \%)$ referiu a disponibilização gratuita por intermédio do posto de saúde, seja este localizado dentro ou fora do povoado de moradia.

Dados semelhantes foram encontrados na literatura em relação à população quilombola de Boqueirão. De acordo com as declarações dos moradores daquela região, os profissionais mais procurados por ocasião de adoecimento são os agentes de saúde municipais $(73,3 \%)$, seguidos de médicos $(17,6 \%)$, enfermeiros $(8,4 \%)$ e demais profissionais $(0,7 \%)$. E, quanto ao acesso a medicamentos, a maioria da população de Boqueirão também declara adquiri-los no posto de saúde ${ }^{(220)}$.

Sobre o principal tipo de serviço de saúde oferecido à comunidade, $84,1 \%(n=169)$ dos Kalungas fizeram menção ao posto de saúde, 9,5\% (n=19) à ESF e 6,4\% (n=13) às unidades hospitalares. O destaque ao posto de saúde pode estar relacionado ao fato destes serem frutos de conquistas sociais recentes do povo Kalunga, a partir de 2011. Até então, a comunidade não dispunha deste tipo de unidade de atendimento, sendo que, em situações mais graves, as pessoas precisavam se deslocar para municípios mais próximos da Reserva Kalunga. Nestes casos, os doentes eram transportados em "leiteiras" (redes de dormir) por parentes até o local 
do transporte, sendo a falta de assistência em saúde referenciada como um dos principais problemas enfrentados pela comunidade ${ }^{(224)}$.

Quando se enfoca as comunidades quilombolas e seu acesso às políticas de saúde, não há como deixar de mencionar o grave problema das crianças em um contexto que acaba por aumentar o baixo índice de indicadores de saúde entre este grupo da população quilombola ${ }^{(264,265)}$.

De tal modo, com bases nos resultados encontrados, é possível destacar que, dentre a população Kalunga que já esteve ou está em idade reprodutiva $(n=124), 33,9 \%(n=42)$ refere histórico de pelo menos um filho nascido morto. Na Figura 17 é mostrada a proporção de acordo com o município de moradia dos quilombolas entrevistados.

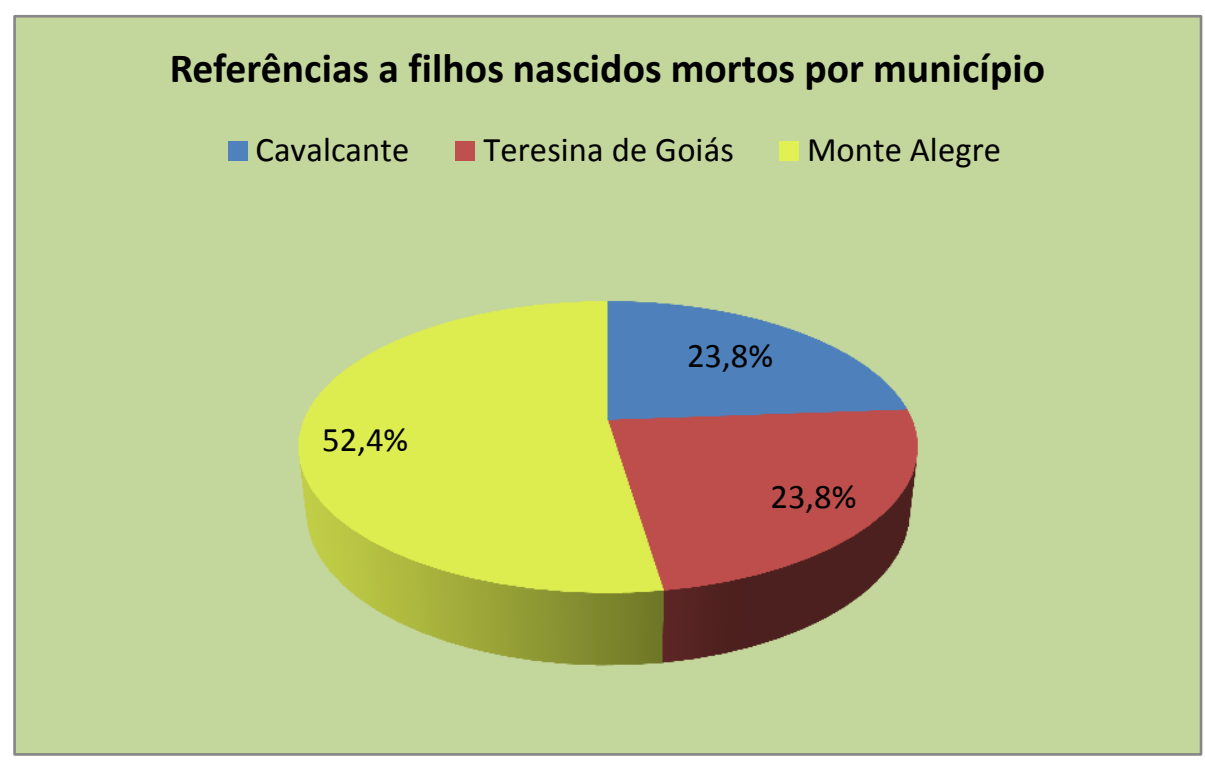

Figura 17 - Referências a filhos nascidos mortos por município de residência

Ainda sobre o grupo da população Kalunga que já esteve ou está em idade reprodutiva $(n=124)$, foi identificado que $25,8 \%(n=32)$ dos moradores entrevistados tiveram pelo menos um dos filhos que foi a óbito antes de completar um ano de idade. Na Figura 18, é mostrada a distribuição de filhos mortos antes de completar o primeiro ano de idade. 


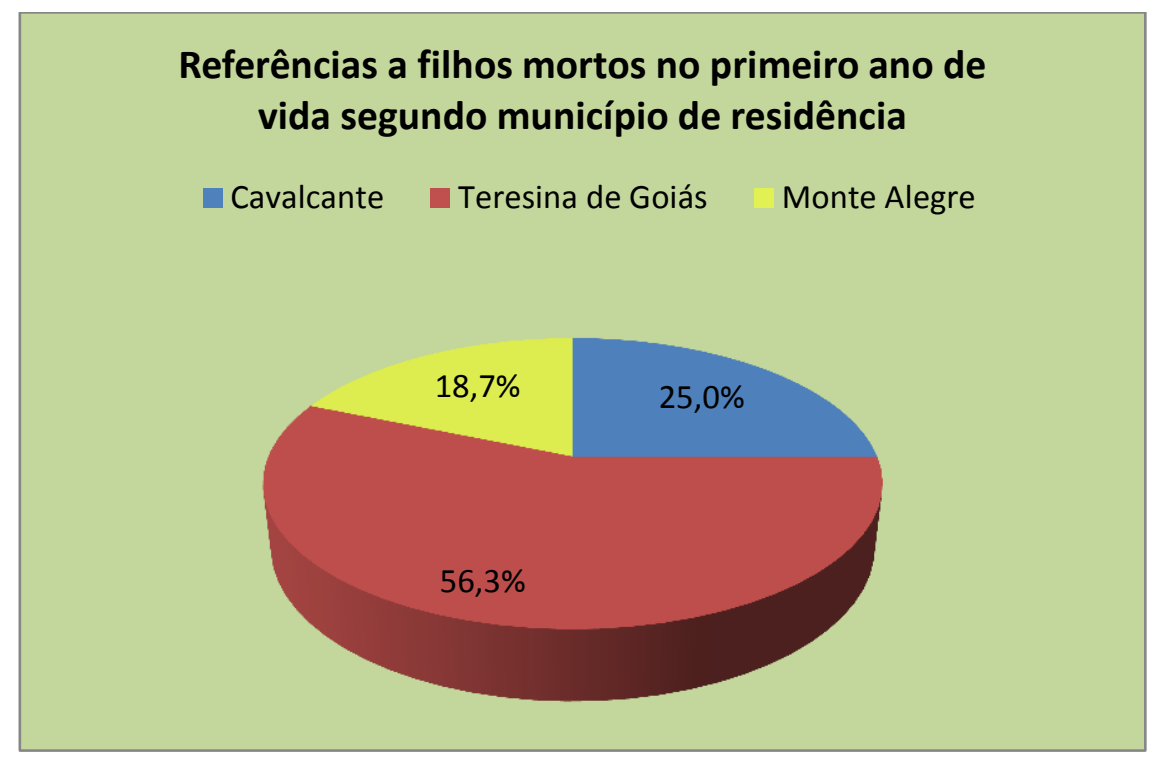

Figura 18 - Distribuição das referências a filhos mortos antes de completar um ano segundo município de residência

Sobre as questões relacionadas com a taxa de mortalidade, pode-se afirmar que grupos étnicos de origem indígena e quilombola mostram padrões diferenciados de mortalidade quando comparados com a população urbana e rural do país. Os diferenciais de mortalidade infantil observados entre a população quilombola demandam investigações mais detalhadas; contudo, independentemente de maiores interpretações, é evidente a situação de elevada vulnerabilidade e risco de morte entre as crianças menores de um ano, sendo a falta de acesso a serviços de saúde uma possível hipótese justificativa para tais achados ${ }^{(266)}$.

Na verificação da situação vacinal, 83,1\% (n=167) informaram estar com o esquema vacinal em dia, enquanto $16,9 \%(n=34)$ relataram nunca terem recebido vacinas e nem participação de campanhas de vacinação mesmo quando estas ocorrem em seus povoados. $\mathrm{Na}$ Figura 19 é mostrada a distribuição dos moradores com o esquema vacinal completo segundo o município de residência. 


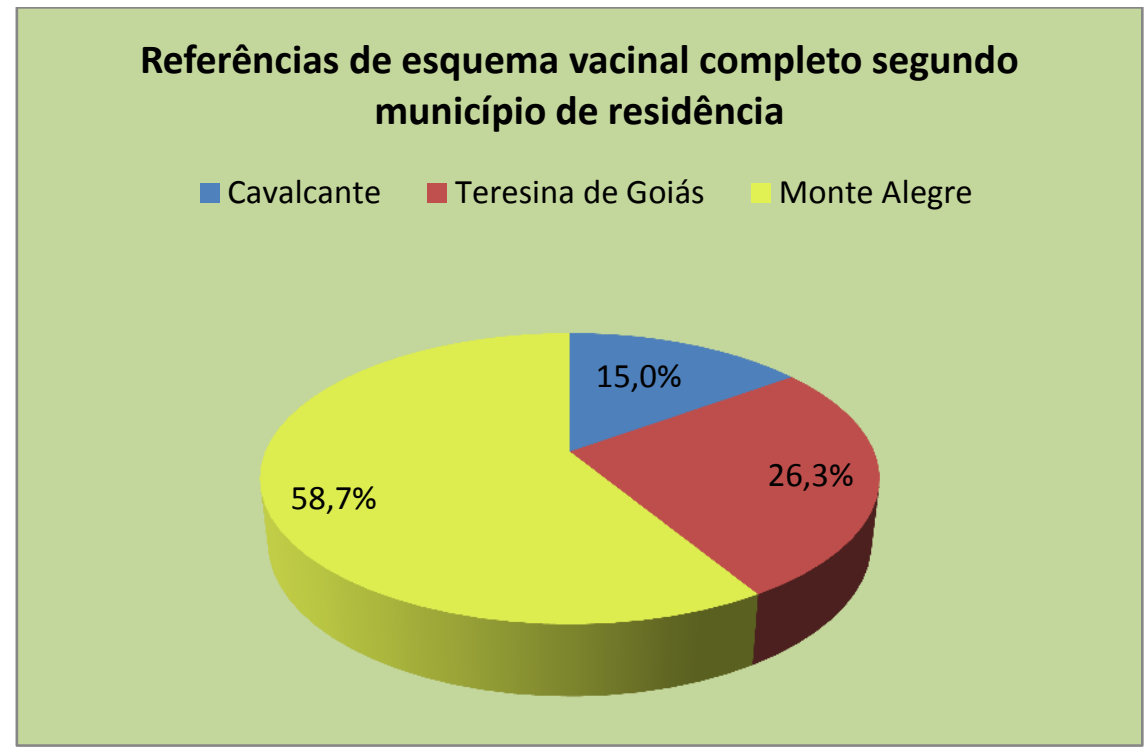

Figura 19 - Distribuição de referências ao esquema vacinal completo segundo município de residência

O consumo do tabaco e do álcool entre os quilombolas Kalungas merece destaque por ser um problema de risco social, à saúde e, em especial, pelo relato dos moradores de serem precárias as informações disponibilizadas a eles sobre os riscos e consequências relacionados a esses hábitos ${ }^{(58)}$. Dos 201 quilombolas Kalungas pesquisados, 54 (26,9\%) são fumantes, sendo constatado um ligeiro predomínio na composição do grupo por indivíduos do sexo feminino, uma vez que $42,6 \%(n=23)$ das respostas afirmativas para o tabagismo foi proferida por homens e 57,4\% $(n=31)$ por mulheres. Com relação à faixa etária, 70,4\% $(n=38)$ dos fumantes têm entre 18 e 60 anos; 27,8\% (n=15) têm 61 anos ou mais e 1,9\% $(n=1)$ tem menos de 18 anos.

Sobre o hábito de fumar, entre os Kalungas é frequente, em especial pelos mais velhos, o uso do cachimbo e do cigarro de palha, sendo o cigarro de papel frequentemente consumido de modo ocasional, demandando contato prévio com citadinos ${ }^{(267)}$. Estudo com remanescentes de quilombo de Vitória da Conquista, na Bahia, identificou uma proporção um pouco menor de fumantes do que o encontrado na presente pesquisa, 19,8\%, dos quais 9,3\% corresponde ao sexo feminino e $31,8 \%$ ao masculino. A taxa de ex-fumantes encontrada foi de $27,3 \%$, sendo $9,3 \%$ mulheres e $31,8 \%$ homens $^{(268)}$.

Na Figura 20, é mostrada a distribuição dos fumantes segundo o município de moradia. 


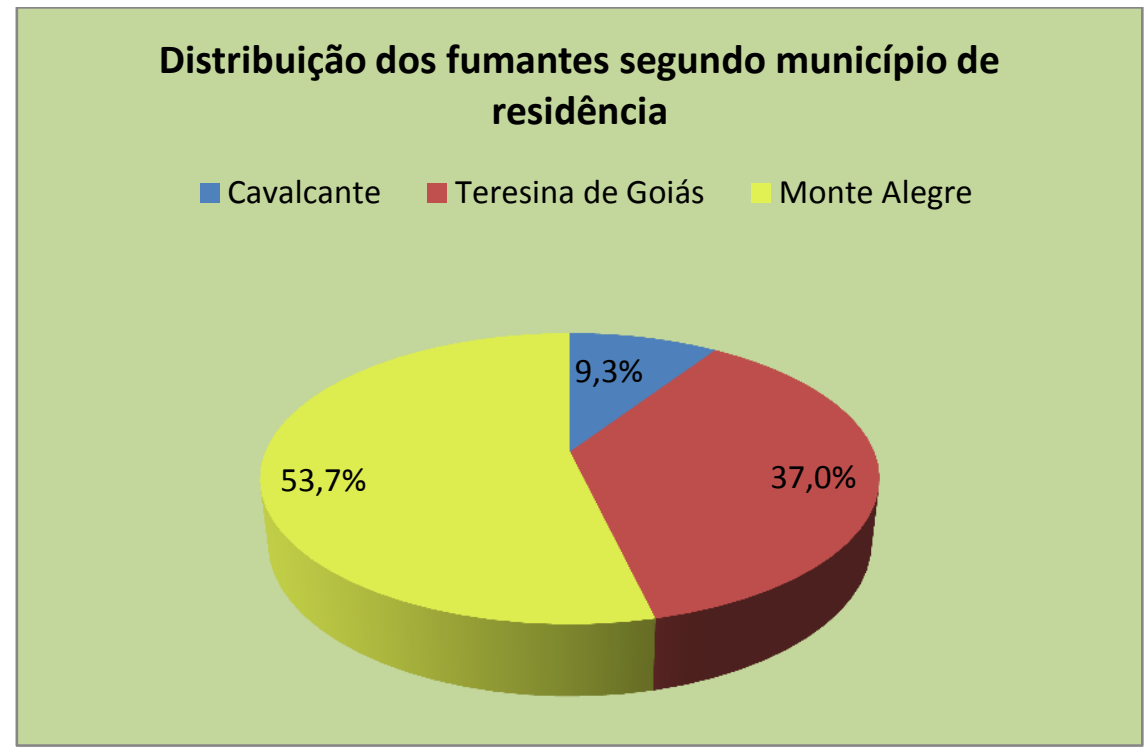

Figura 20 - Distribuição dos moradores quilombolas fumantes por município

O uso do álcool foi identificado em 31,3\% ( $\mathrm{n}=63)$ dos respondentes, havendo semelhança na distribuição por gênero dos moradores com hábito de consumo de álcool, $50,8 \%(n=32)$ pertencentes ao sexo masculino e 49,2\% (n=31) ao feminino. Quanto à distribuição por idade, identificou-se que 69,8\% (n=44) dos etilistas têm entre 18 e 60 anos; 22,2\% (n=14) têm 61 anos ou mais e 7,9\% (n=5) têm menos de 18 anos. Na Figura 21, é mostrada a distribuição dos moradores com hábito de consumo de álcool segundo o município que residem.

Por fim, a associação entre tabagismo e hábito do consumo de álcool foi verificada em 15,4\% ( $\mathrm{n}=31)$ da população do estudo. Assim, enfermidades decorrentes destes hábitos nocivos à saúde e a exacerbação de outras condições estabelecidas, demonstram a necessidade do planejamento e implementação de estratégias especiais junto a este grupo populacional singular ${ }^{(262,269)}$. A falta de perspectiva com relação ao futuro e ao crescimento pessoal, somada às difíceis condições de moradia e à falta de políticas de valorização do homem do campo, têm sido apontados frequentemente como causa dos altos índices de alcoolismo e tabagismo entre as populações quilombolas ${ }^{(54)}$. Em outras palavras, a exacerbação do alcoolismo decorrente da falta de perspectivas profissionais e de mudança no patamar social e o hábito tabagista disseminado como prática isenta de prejuízos acabam por formar um ciclo complexo que demanda atenção em se tratando da promoção à saúde quilombola, em especial, por meio da implementação de ações afirmativas oriundas de Políticas Públicas de Saúde ${ }^{(270)}$. 


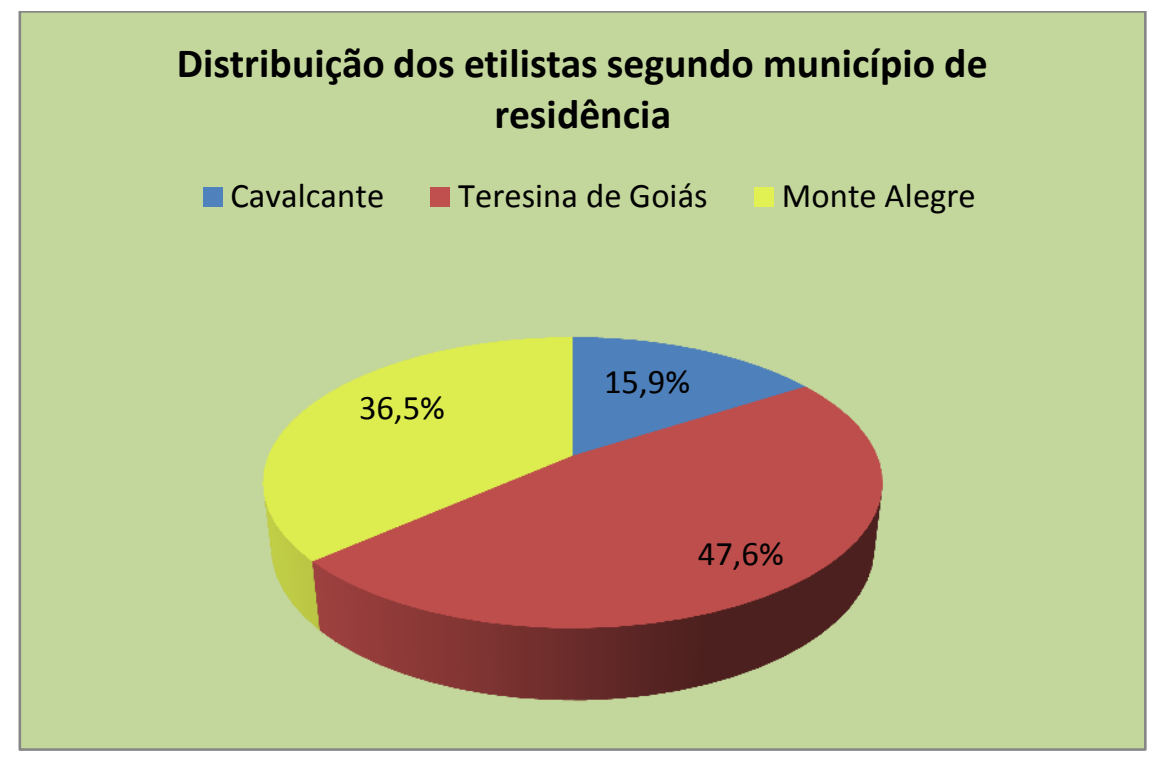

Figura 21 - Distribuição dos moradores quilombolas usuários de álcool, por município

A importância do recorte étnico/racial na assistência e na atenção em saúde relativa às doenças e às condições de vida da população negra possibilita que sejam identificados contingentes populacionais mais suscetíveis a agravos à saúde, como no caso da hipertensão $\operatorname{arterial}^{(54)}$.

No estudo verificou-se que 9,5\% $(n=19)$ da população apresentava diagnóstico prévio de hipertensão arterial, contudo, 14,6\% $(n=29)$ dos moradores, em três aferições seguidas por ocasião das entrevistas, estavam com os níveis tensionais acima do preconizado como padrão desejável, ou seja, apresentavam pressão arterial sistólica maior ou igual a $140 \mathrm{mmHg}$ e uma pressão arterial diastólica maior ou igual a $90 \mathrm{mmHg}$. Tal achado pode indicar uma predominância na tendência de populações negras em desenvolver quadros de hipertensão ou mesmo dificuldades de acesso à assistência médica, pois verificou-se que 47,3\% (n=95) dos quilombolas do estudo declararam nunca ter aferido a pressão arterial.

Em estudo, Silva ${ }^{(90)}$ assinala a ocorrência entre população quilombola, de subnotificação em relação aos casos de hipertensão arterial, um agravo de alta prevalência na população negra, bem como salienta o amplo desconhecimento existente, entre estes grupos, dos fatores de risco ligados à doença e seu tratamento.

No grupo dos Kalungas hipertensos houve predomínio de indivíduos do sexo feminino $(n=13 ; 68,4 \%)$ em relação ao masculino $(n=6 ; 31,6 \%)$. Com relação à adesão ao tratamento, apenas $21,1 \%(n=4)$ dos hipertensos $(n=19)$ referem fazer acompanhamento periódico em unidade de saúde com utilização diária de medicação anti-hipertensiva, o que, no caso, 
poderia refletir uma concordância entre as orientações em saúde e o comportamento do indivíduo, pressupondo-se que o este conhece as alternativas terapêuticas e participa nas decisões sobre seu tratamento.

Dentre o grupo de Kalungas em acompanhamento e tratamento da hipertensão arterial $(n=4), 75,0 \%(n=3)$ relatam que recebem a medicação anti-hipertensiva gratuitamente junto às unidades básicas de saúde; 25,0\% $(\mathrm{n}=1)$ referem adquirir a medicação prescrita pelo profissional de saúde na cidade mais próxima ao povoado em que reside. Na Figura 22, é mostrada a distribuição dos quilombolas Kalungas hipertensos segundo o município de moradia.

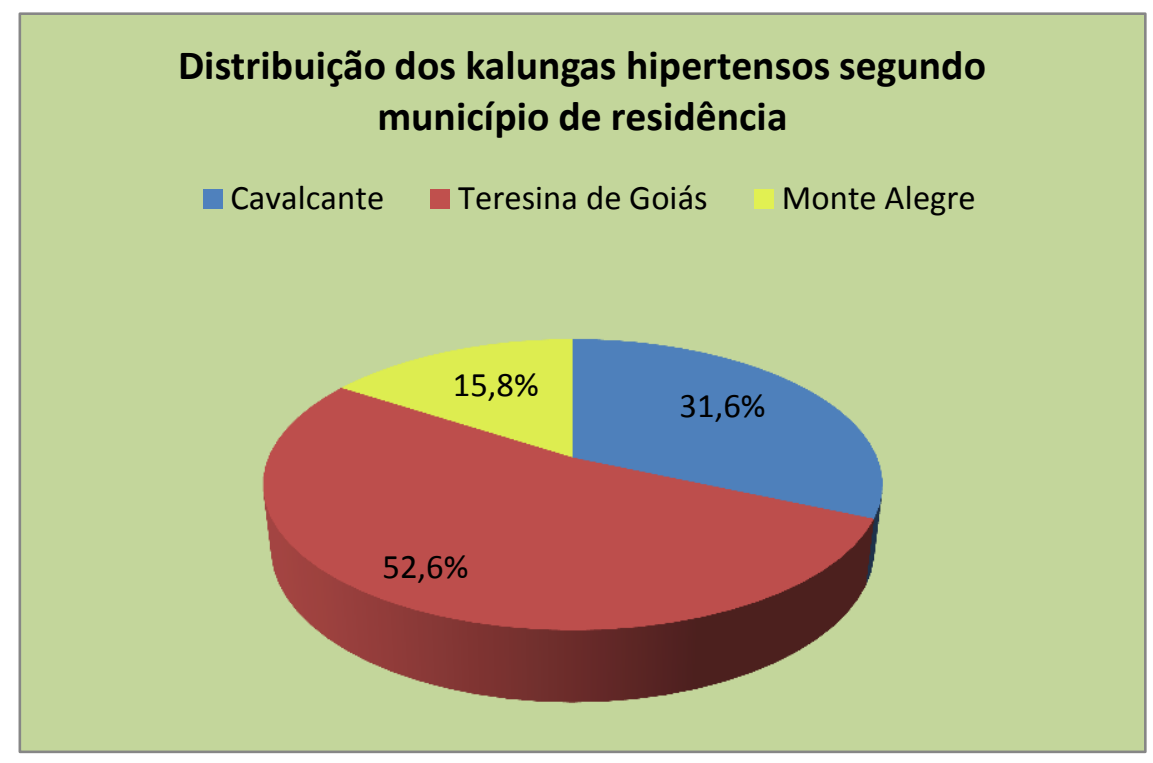

Figura 22 - Distribuição dos quilombolas hipertensos por município de residência

Em estudo realizado anteriormente com o objetivo de avaliar na população Kalunga os níveis pressóricos e sua relação com outras variáveis, entre elas, sexo e idade, foi verificado que $6,28 \%$ da população estavam compostos por indivíduos hipertensos, não sendo observadas diferenças estatisticamente significativas de PA com relação ao sexo e à idade, em nível de até $10 \%{ }^{(267)}$. Por outro lado, em estudo realizado sobre a avaliação das condições habitacionais e de saúde da comunidade quilombola Boqueirão, encontrou-se uma proporção maior de hipertensos, uma vez que $23 \%$ dos indivíduos entrevistados declararam sofrer de hipertensão ${ }^{(220)}$. A proporção de hipertensos na comunidade quilombola Caiana dos Crioulos foi a que mais se aproximou dos resultados do estudo em pauta, sendo as incidências de hipertensão feminina e masculina de $16,44 \%$ e $16,13 \%$, respectivamente ${ }^{(90)}$. 
Os resultados ora descritos acerca da hipertensão arterial no contexto da Comunidade Kalunga reforçam a importância de um amplo programa de promoção e acesso aos serviços de saúde para diagnóstico precoce, bem como orientações para o manejo adequado da mesma, com vista à equidade em saúde e a melhoria da condição de vida das minorias quilombolas.

As comunidades rurais enfrentam graves problemas sociais de influência sobre a saúde; problemas potencialmente agravados quando se leva em conta a grande lacuna excludente que sempre acompanhou as populações negras e quilombolas, sendo comum a descrição de doenças que ocorrem, principalmente, devido à ausência de condições sanitárias adequadas, como diarreias, verminoses, entre outras ${ }^{(271)}$.

Assim, quando questionados sobre as doenças frequentes que acometem os moradores Kalungas, os indivíduos entrevistados citaram a diarreia, a escabiose e o tracoma, sendo que em 63,3\% (n=128) dos casos a diarreia foi apontada exclusivamente; em 14,4\% ( $n=29)$ houve referência conjunta à diarreia e à escabiose; 11,9\% (n=24) a diarreia e ao tracoma, e 10,0\% $(n=20)$ a diarreia, escabiose e tracoma.

A diarreia foi apontada por grande parte da população como um dos principais problemas de saúde da comunidade, sendo a ocorrência de episódio diarreico entre pelo menos um dos moradores do domicílio no último mês, citada por 91,0\% (n=183) da população pesquisada. Deste total $(n=183)$, uma proporção de 40,4\% (n=74) referiu um intervalo menor para a ocorrência do episódio de diarreia, aproximadamente quinze dias ou menos. Houve diferença na distribuição por gênero dos respondentes que referiram episódio diarreico entre os moradores da residência no último mês, $41,0 \%(n=75)$ pertencem ao sexo masculino e $59,0 \%(n=108)$ ao feminino.

Quanto ao membro da família que apresentou o último episódio diarreico, as crianças foram mais frequentemente citadas, sendo em 40,4\% $(n=74)$ dos casos apontadas exclusivamente e em 15,8\% (n=29) referidas conjuntamente com outro membro do domicílio. Acrescenta-se ainda que, dos domicílios referenciados com casos de diarreia entre seus moradores, 39,9\% (n=73) não possuem abastecimento por água encanada.

Na Figura 23, é mostrada a distribuição por município de residência dos casos de diarreia no último mês. 


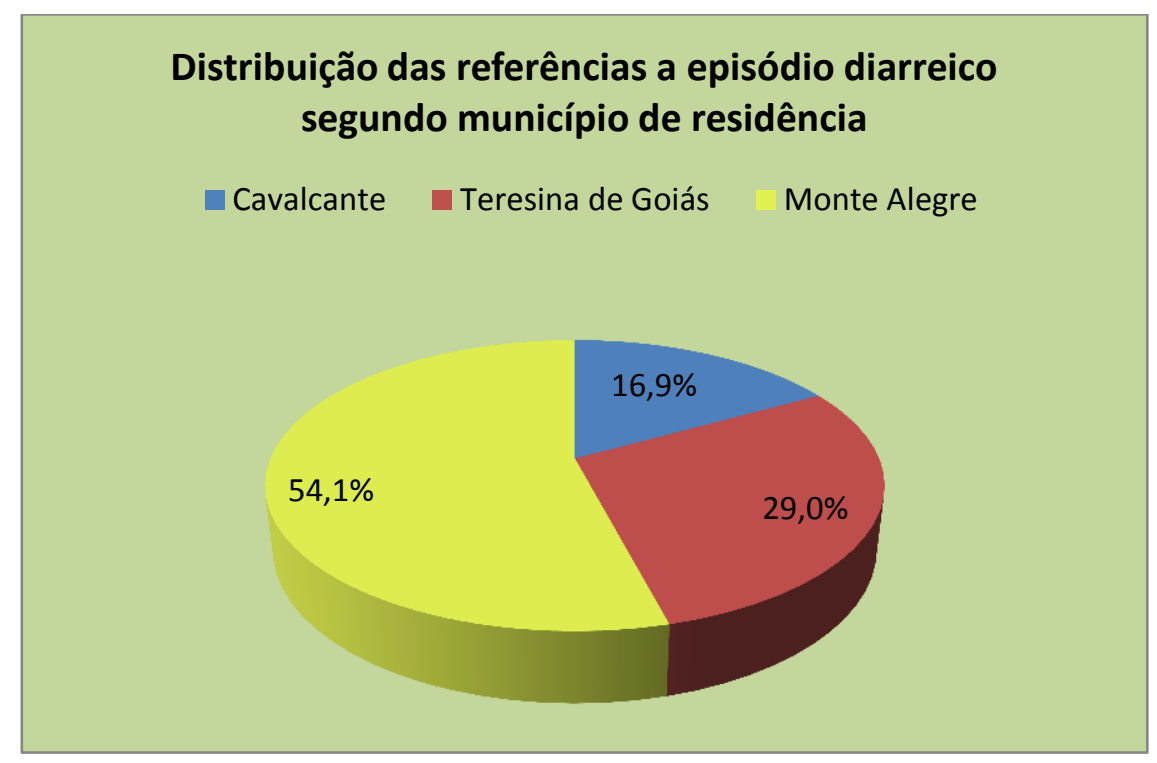

Figura 23 - Distribuição dos episódios diarreicos segundo município de residência

Com relação aos fatores apontados pelos quilombolas como relacionados à ocorrência do evento diarreico, em 56,3\% ( $\mathrm{n}=103)$ dos casos a diarreia foi associada com a existência de contexto causal anterior, dos quais 45,4\% (n=83) refere associação com "andaço" (vários membros da comunidade apresentando episódio diarreico em um intervalo de tempo semelhante) ou com fatores da própria natureza (como calor e poeira), ou, ainda, com evento do próprio corpo humano como o nascer de dentes.

As principais referências de conduta para a resolução do quadro diarreico foram a adoção de intervenções oriundas do saber popular, como o uso de chás, infusões e preparos ( $\mathrm{n}=98 ; 53,6 \%)$, seguida pela opção da não intervenção $(\mathrm{n}=64 ; 35,0 \%)$, "uma vez que a diarreia resolve-se por si só" e, por fim, pela busca de orientações dos profissionais da saúde $(n=20 ; 10,9 \%)$.

A escabiose também foi destacada pelos moradores entrevistados como um dos principais agravos em saúde presentes na comunidade Kalunga, o que pode ser explicado pelo fato da escabiose ser uma das dermatozoonoses mais prevalentes, ser transmitida por contato pessoal e por seu caráter de transmissibilidade fortemente influenciado por fatores socioeconômicos e culturais ${ }^{(272)}$.

Foi constatado que 25,4\% $(n=51)$ da população do estudo referiram episódio de escabiose entre os moradores do domicílio nos últimos seis meses, sendo a população adulta a principal acometida em 66,7\% $(\mathrm{n}=34)$ dos casos. Quanto à distribuição por gênero, 31,4\% $(\mathrm{n}=16)$ dos relatos de escabiose estiveram relacionados a indivíduos do sexo masculino e 
68,6\% ( $\mathrm{n}=35)$ do feminino, o que demonstra uma diferença entre as proporções com nítida predominância, entre os casos, do sexo feminino sobre o masculino.

Acrescenta-se ainda que, entre as referências de casos de escabiose, 17,6\% ( $n=16)$ relataram não possuir casas abastecidas com água encanada, enquanto 58,8\% ( $\mathrm{n}=30)$ afirmaram viver com renda mensal inferior a um salário mínimo e 49,0\% (n=25) relataram coabitar com quatro ou mais pessoas, o que pode aumentar o risco de transmissão da escabiose.

Na Figura 24, é mostrada a distribuição segundo município dos casos referidos de escabiose.

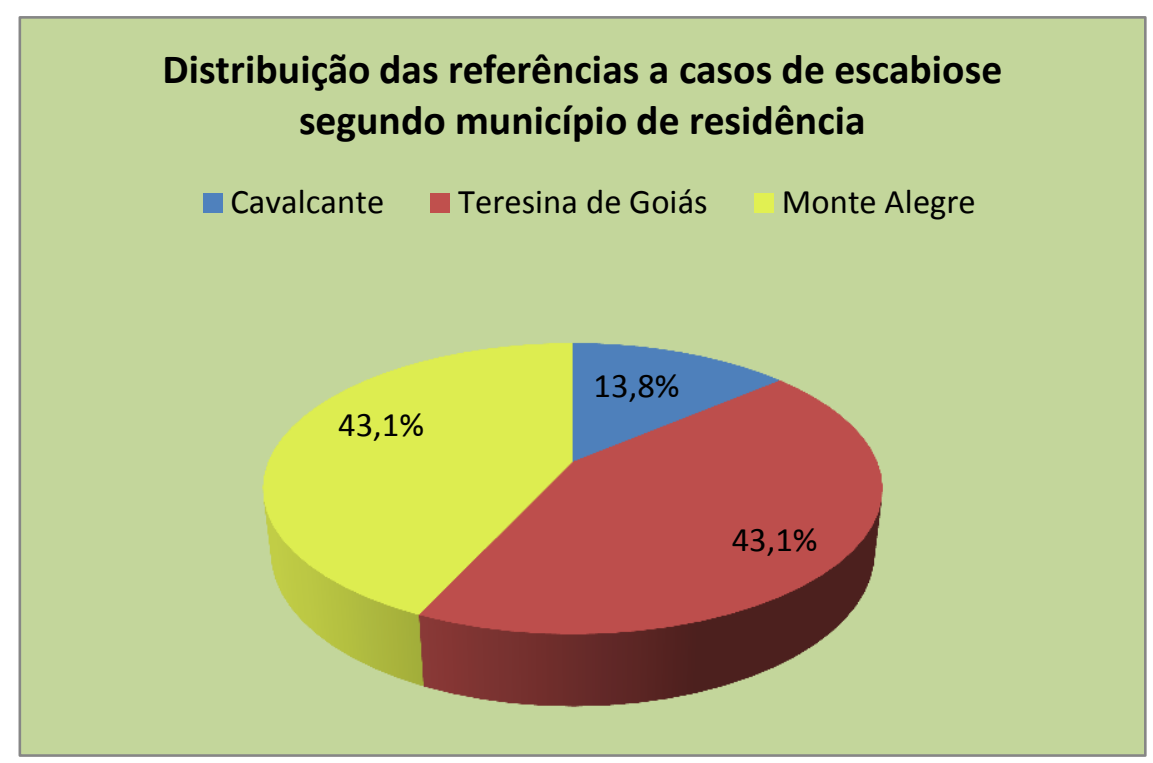

Figura 24 - Distribuição dos casos de escabiose segundo município de residência

Entre os quilombolas que referenciaram a existência de casos de escabiose entre os moradores da residência, 49,0\% ( $n=25)$ inferem não existir causa explicável para o agravo ou não saber apontar tal causa; 39,2\% $(n=21)$ referem aspectos ambientais, tais como estação do ano, poeira ou calor; e, 9,8\% $(\mathrm{n}=5)$ apontaram fatores outros como responsáveis pela ocorrência da escabiose.

Como conduta adotada para a resolução do quadro clínico de escabiose, 53,0\% (n=27) da população que apresentou episódio de escabiose referiu não ter adotado nenhuma conduta específica enquanto tratamento, 37,2\% (n=19) informou tratamento a partir de ações do senso comum e saber popular, e, apenas 9,8\% (n=5) apontou a adoção de ações a partir da orientação obtida junto ao serviço formal de saúde oferecido à comunidade. 
O tracoma, ceratoconjuntivite bacteriana crônica e redicivante têm sua transmissão relacionada ao ambiente doméstico de forma direta (olho para olho ou mãos contaminadas) ou indireta (vestuários ou proliferação de moscas), acometendo, majoritariamente, populações rurais e/ou pobres devido à fragilidade de alguns aspectos higiênico-sanitários e às restrições no acesso a benefícios oriundos do desenvolvimento ${ }^{(273)}$. Assim, no contexto da população rural quilombola Kalunga, 22,4\% $(\mathrm{n}=45)$ dos entrevistados mencionaram episódio de tracoma entre os moradores do domicílio.

Destes, $51,1 \%(n=23)$ referem a ocorrência do tracoma há mais de um mês; $57,8 \%$ $(\mathrm{n}=26)$ têm a renda mensal familiar inferior a um salário mínimo; e, 68,9\% $(\mathrm{n}=31)$ residem em casas sem o abastecimento de água encanada. A distribuição das referências aos casos de tracoma por idade demonstra que 55,6\% $(\mathrm{n}=25)$ têm entre 18 e 60 anos, 33,3\% (n=15) são menores de 18 anos e 11,1\% (n=5) possuem 61 anos ou mais, sendo maior a proporção entre os moradores do sexo feminino $(n=28 ; 62,2 \%)$ quando comparados ao masculino $(n=17$; $37,8 \%$ ). Na Figura 25, é mostrada a distribuição segundo município dos casos referidos de tracoma.

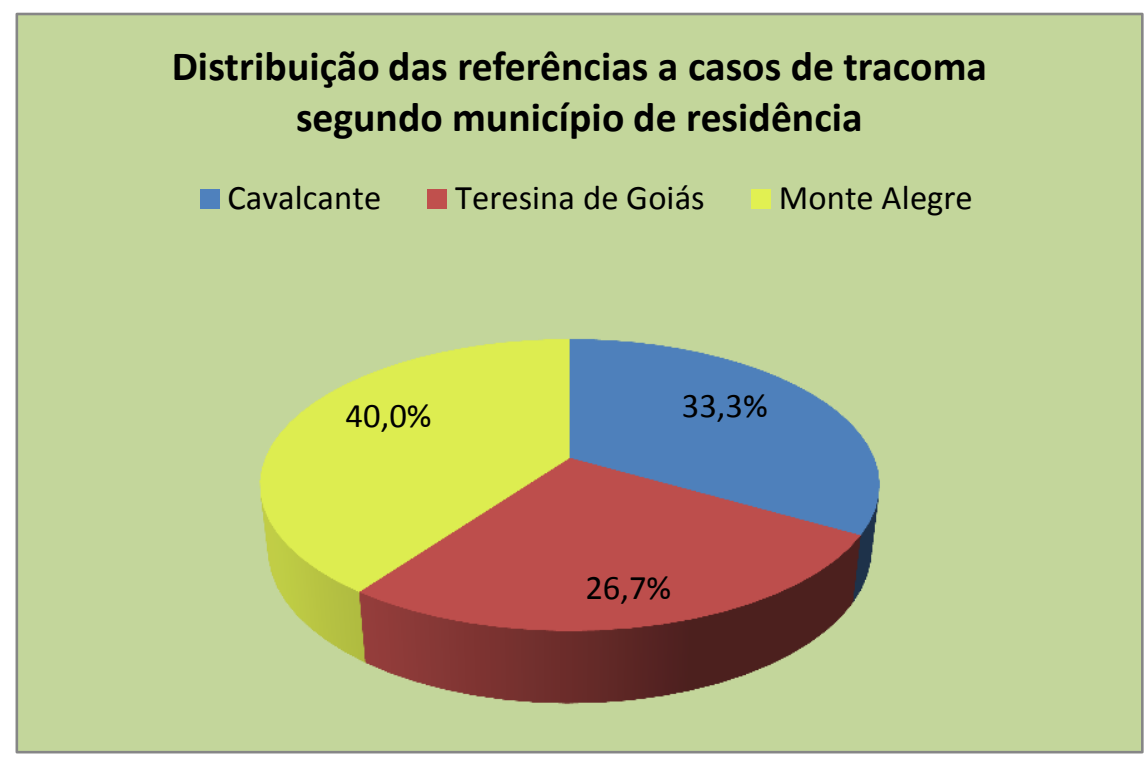

Figura 25 - Casos referidos de tracoma segundo município de residência

No que tange ao estabelecimento de relação entre a ocorrência do tracoma e a existência de fatores predisponentes ou causais, 53,3\% (n=24) da população em estudo não associaram o acometimento em saúde por tracoma a outros eventos anteriores; 35,6\% ( $\mathrm{n}=16)$ apontaram aspectos biológicos, naturais ou do ambiente como principais responsáveis pela ocorrência do tracoma: nascer de dentes, estação do ano, vento, calor ou poeira; e, por fim, $11,1 \%(n=5)$ referiram aspectos outros como causadores do agravo. 
Entre os indivíduos que referenciaram casos de tracoma entre os moradores da residência $(n=45 ; 100 \%), 51,1 \%(n=23)$ afirmaram não ter sido adotada nenhuma conduta específica visando à resolução das manifestações e sintomas da doença; 26,7\% (n=12) informaram tratamento a partir de ações do senso comum e saber popular (chás, preparos a partir de plantas e raízes ou rezas); 20,0\% (n=9) apontaram ações a partir da orientação obtida junto ao serviço formal de saúde oferecido à comunidade; e 2,2\% $(n=1)$ da população em estudo optou pela adoção de outras medidas para a resolução do problema.

Secularmente, as condições de saúde desse grupo étnico, os quilombolas, não têm sido das mais favoráveis, e sabe-se que condições sociais e materiais influenciam de forma indireta no processo saúde/doença, e, consequentemente, na qualidade e expectativa de vida dessas $\operatorname{minorias}^{(274)}$.

Por esse motivo, é importante priorizar a busca da equidade por meio do acesso ao sistema de saúde e da utilização dos serviços que promovam melhoria na qualidade da atenção específica dessas populações ${ }^{(275)}$, entendendo que saúde enquanto qualidade de vida se insere como uma questão sociocultural, envolvendo tanto os indivíduos, protagonistas deste processo, quanto as autoridades competentes com a responsabilidade de implementar políticas públicas que atendam às necessidades básicas dos sujeitos de direitos ${ }^{(262)}$. 
CAPÍTULO 7 


\section{CONSIDERAÇÕES FINAIS}

As políticas públicas direcionadas à população afrodescendente, notadamente os quilombolas, foram legitimadas com a Constituição Federal de 1988, possibilitando a esse segmento da população maior visibilidade, acesso a bens de consumo e assistência à saúde. Contudo, tais conquistas ainda estão longe de refletir a ruptura da condição de vulnerabilidade historicamente construída. Não obstante, a conquista dos direitos serem recentes, ainda carece de efetivação quanto ao atendimento dos anseios da população Kalunga em ter seus pleitos atendidos em prol da melhoria nas condições de vida, pois as iniquidades são mais intensas quando comparadas com os demais membros da sociedade.

Reconhecidos como remanescentes de quilombos ou quilombolas contemporâneos, esse grupo étnico-racial, apenas nos últimos anos tem recebido atenção mais destacada das entidades governamentais e sociedade civil. É notória a escassez de estudos e, consequentemente, a falta de informações sobre o perfil socioeconômico-demográfico e de saúde das populações referidas. De tal maneira, estas questões se constituem em tema atual e de relevância ímpar, o que ratifica e justifica a demanda pela realização de pesquisas que gerem indicadores a serem utilizados na elaboração de programas ou políticas públicas específicas para esta população. O investimento na maior eficácia e os impactos de tais políticas podem contribuir na superação da situação de exclusão e abandono vivenciadas por grupos quilombolas minoritários, promovendo meios que garantam o acesso equânime a direitos sociais e econômicos, incluindo saúde.

Os resultados apresentados no estudo constituem evidências pioneiras sobre as condições sanitárias da população Kalunga, com ênfase na caracterização do perfil socioeconômico-demográfico e epidemiológico, bem como na avaliação de aspectos correlatos ao ambiente e às condições de saúde de moradores quilombolas nos municípios de Cavalcante, Teresina de Goiás e Monte Alegre, Estado de Goiás.

Abordaram-se alguns determinantes sociais de saúde, doenças prevalentes, moradia, transporte, abastecimento e qualidade da água, destinação de resíduos e dejetos humanos, com vistas à geração e divulgação de dados que possam colaborar com os setores competentes na tomada de decisões relativas às questões quilombolas, com ênfase às correlatas ao povo Kalunga. Tal aplicabilidade prática relaciona-se, ainda, ao compromisso social pela construção da equidade em saúde, envidando esforços para a superação da chamada "danosa 


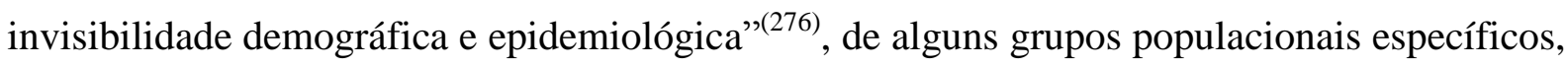
como é o caso dos quilombolas residentes no Sítio Histórico e Patrimônio Cultural Kalunga.

Os resultados do estudo mostraram a precariedade das condições de vida e a carência no acesso a bens e serviços entre a população Kalunga, haja vista que muitos destes quilombolas encontram-se abaixo da linha da pobreza e outros tantos até mesmo abaixo da linha da indigência ${ }^{(55)}$. Tal condição de pobreza extrema é refletida no enfrentamento de problemas graves como: analfabetismo, baixo índice de renda per capta, condições deficitárias de moradia, limitações de acesso e de utilização de serviços de saúde e educação e, principalmente, falta de infraestrutura e saneamento - precariedade nas condições higiênicosanitárias, com a utilização de água não tratada e a ausência de rede de esgoto.

Assim, foi possível evidenciar aspectos de vulnerabilidade no que tange aos determinantes sociais da saúde, em especial, frente às desigualdades e iniquidades relacionadas às condições ambientais e sanitárias, o que, indubitavelmente, impacta negativamente nas condições de saúde e qualidade de vida deste grupo.

A saúde, em seu conceito ampliado, não é percebida apenas como a ausência de doenças. Ela se define enquanto resultante das condições de acesso aos serviços de saúde, alimentação, habitação, educação, renda, meio ambiente, trabalho, transporte, emprego, lazer, liberdade e posse da terra, sendo inquestionável sua influência sobre condições e qualidade de vida, e vice-versa. Laurell ${ }^{(18)}$ complementa caracterizando-a como 'necessidade humana' cuja satisfação associa-se imediatamente a um conjunto de condições, bens e serviços que permitem o desenvolvimento individual e coletivo de capacidades e potencialidades, conforme os níveis de recursos sociais existentes e os padrões culturais de cada contexto específico.

Por isto, quando se enfoca a saúde das populações Kalungas, é necessário, contextualizá-la enquanto resultado das formas de organização social e de produção, as quais podem gerar grandes desigualdades nos níveis de vida ${ }^{(12)}$. O contexto de vulnerabilidade dos Kalungas corrobora o proposto, uma vez que o processo saúde-doença é eminentemente social, influenciado pelas relações dos homens com a natureza (meio ambiente, espaço, território) e com outros homens (por meio do trabalho e das relações sociais, culturais e políticas), em um determinado espaço geográfico e tempo histórico ${ }^{(38)}$. 
A conjuntura de injustiças sociais identificada no acesso desigual a recursos materiais, produtos e serviços também refletem desigualdades em saúde, haja vista a grande disparidade de oportunidades e condições de vida dos Kalungas em relação à população brasileira em geral. Esta realidade evidencia certa insipiência na priorização do princípio constitucional da equidade, e, aponta que questões socioeconômicas e ambientais podem servir como indicadores da relação entre as condições sociossanitárias e a ocorrência de inúmeros agravos em saúde, a exemplo das infestações enteroparasitárias.

Com relação ao perfil parasitológico de moradores Kalungas, os resultados desta pesquisa mostraram a inadequação das condições de saneamento nas comunidades investigadas, que favorece tanto os elevados níveis de parasitismo intestinais quanto a possibilidade de ocorrência de poliparasitismo. Tais achados demonstram que os povos quilombolas constituem um segmento socioeconomicamente desfavorecido no Brasil, o qual, em larga medida, está excluído das principais intervenções públicas capazes de melhorar as condições de vida e de saúde, como saneamento ou abastecimento de água apropriada para consumo humano.

Entre os moradores Kalungas pesquisados, destaca-se a influência das péssimas condições de higiene pessoal e domiciliar, assim como a inobservância do cuidado com a água e com os alimentos, aspectos que contribuem para as altas taxas de prevalência de enteroparasitas, sejam patógenos ou comensais. Em adição, os moradores apresentaram infestações por diferentes espécies de parasitos relacionados a episódios diarreicos, o que esteve fortemente associado às condições de saneamento e higiene precárias, com ênfase na falta de tratamento da água para consumo humano.

Em decorrência das condições referidas, que são preponderantes, e, em não havendo o emprego de medidas saneadoras, é possível que as condições detectadas se mantenham enquanto situações persistentes, acarretadas pela não interrupção dos ciclos de transmissão de doenças parasitárias. O problema é de difícil equacionamento, pois o acesso à saúde é insuficiente, o ambiente é, por vezes, contaminado, e os maus hábitos dos moradores concorrem para novas infestações. Conjuntura, esta, que ratifica a existência de dificuldades na adequação de soluções sanitárias às particularidades locais, sobretudo quanto à questão de adesão da população, que caso não ocorra pode levar à grave consequência de não se atingir objetivos de melhoria da qualidade de vida e da saúde coletiva ${ }^{(277)}$. 
Por tanto, salienta-se que a utilização do saneamento como instrumento de promoção da saúde pressupõe a superação dos entraves tecnológicos, políticos e gerenciais ${ }^{(57)}$ que, como apontado no estudo, pode estar dificultando a extensão de benefícios socioambientais, e, por conseguinte, o alcance de melhores condições de saúde por residentes quilombolas nas áreas rurais do Estado de Goiás. Destacando-se, ainda, que os problemas ambientais são, também, questões eminentemente sociais, geradas e atravessadas por um conjunto de processos que estabelecem importantes interfaces com a saúde de indivíduos, grupos e populações, afetandoos em múltiplas e simultâneas escalas e dimensões ${ }^{(278)}$.

A convivência dos Kalungas próxima à área de garimpo aluvial pode contribuir para a ingestão de peixes contaminados com mercúrio. Embora a maioria dos peixes avaliados apresentassem teores de mercúrio dentro do preconizado na legislação vigente, alguns espécimes cujo tipo de alimentação caracteriza-se em predatório, apresentaram valores acima do nível crítico estabelecido para consumo humano. Este achado reveste-se de importância tanto em se tratando da preservação do meio ambiente (em especial, o bioma aquático) quanto da saúde pública, uma vez que o homem se encontra no topo da cadeia trófica e, ao alimentarse de peixes contaminados, ingere concentrações maiores de $\mathrm{Hg}$, processos de biomagnificação e bioacumulação.

Ainda que o pescado consumido pela população Kalunga apresente sua concentração média de $\mathrm{Hg}$ dentro das normas reguladoras vigentes, e que a frequência de consumo pelos moradores da comunidade seja irregular, se faz relevante o acompanhamento e a avaliação do risco de contaminação por mercúrio nos peixes e nas pessoas, visto que fatores antropogênicos, de longa data, possam estar concorrendo para o acúmulo do metal pesado nos recursos biológicos, fato que pode sugerir que no decorrer do tempo essa situação venha ser modificada.

A importância deste tipo de monitoramento relaciona-se ao fato do mercúrio ser considerado um metal extremamente tóxico, principalmente em sua forma orgânica, sendo capaz de fornecer risco às populações por acarretar danos ao ecossistema e à saúde humana. Ademais, em âmbito nacional, não há banco de dados único com disponibilidade de informações sobre as concentrações de $\mathrm{Hg}$ em peixes e cabelos dos grupos populacionais que habitam as diferentes regiões do país, seja com ênfase no meio ambiente, seja na saúde. É necessário o desenvolvimento de novos estudos que se voltem para esta relação em suas 
múltiplas possibilidades e que atentem, inclusive, para a importância do estabelecimento de valores de background para o mercúrio considerando-se as particularidades populacionais.

O presente estudo alcançou seus objetivos ao efetuar uma avaliação das condições sanitárias da população Kalunga dos municípios de Cavalcante, Teresina de Goiás e Monte Alegre, no Estado de Goiás. Embora limitado como todo inquérito transversal, este estabeleceu uma linha de base a partir da qual poderão ser definidas tendências temporais relativas aos diversos indicadores abordados: caracterização da população por meio das variáveis socioeconômico-demográficas e aspectos epidemiológicos; descrição do perfil parasitológico dos moradores de acordo com as diferentes espécies de infestação detectadas; e definição das condições ambientais e sanitárias de moradores Kalungas, nos aspectos de doenças prevalentes, moradia, transporte, abastecimento e qualidade da água, destinação de resíduos e dejetos humanos. O trabalho também propiciará informações adequadas para a avaliação da efetividade da política e ações direcionadas ao atendimento desta população, pois ele se constitui em um dos primeiros bancos de dados sobre a população quilombola do Estado de Goiás.

Acrescenta-se que o conhecimento do perfil socioeconômico-demográfico e epidemiológico e de saúde dos moradores quilombolas Kalungas favorece a implantação de ações específicas para essas comunidades pelos profissionais de saúde que trabalham nesses municípios, além de auxiliar os gestores na utilização de indicadores de saúde que foram gerados, como referências, no planejamento de ações que possam contribuir com a redução das iniquidades que foram reveladas. Salienta-se que o agir em promoção à saúde é aqui entendido enquanto instrumento do processo de capacitação da comunidade para atuar na melhoria de sua qualidade de vida e saúde.

Para se pensar acerca das comunidades quilombolas e seu acesso às políticas de saúde, é fundamental entender que o isolamento das comunidades, a falta de investimentos e a não implementação satisfatória de políticas públicas têm se consolidado em empecilhos para a melhoria da saúde deste grupo. A superação deste quadro de desigualdades e graves iniquidades demanda, imprescindivelmente, que as políticas públicas, cada vez mais, se ocupem da organização de estratégias de prevenção de doenças prevalentes e da promoção da saúde e não apenas de medidas terapêuticas para riscos ou danos já instalados, sendo sua responsabilidade de funcionamento compartilhada entre os sujeitos, suas famílias, serviços de saúde e governo. Outrossim, torna-se imperioso o planejamento de ações na área de saúde a 
partir de uma lógica de funcionamento que, prioritariamente, busque a integralidade, a equidade e a universalidade, da saúde e de seu acesso, em prol da efetiva inclusão cidadã destas populações minoritárias.

Desta forma, conclui-se que os Kalungas se caracterizam enquanto grupo social que apresenta uma identidade étnica, cultural e social que os distinguem do restante da sociedade. Eles vivem em uma histórica condição de vulnerabilidade associada aos determinantes sociais de saúde, demandando, por conseguinte, a especificidade de esforços governamentais e da sociedade em geral, visando igualdade e equidade, principalmente em se tratando de condições epidemiológicas e sanitárias, visto que estas impactam na situação de saúde dos moradores, comprometendo a garantia deste que é um direito legal inalienável a todo cidadão brasileiro. 


\section{CAPÍTULO 8}




\section{RECOMENDAÇÕES}

As autoridades sanitárias, com base nas informações geradas e disponibilizadas, passam a dispor de subsídios técnico-científicos que podem ser utilizados durante a elaboração de medidas e implantação de políticas ou programas direcionados às especificidades deste grupo étnico-social. Dessa forma, os resultados sobre a caracterização das condições epidemiológicas e sanitárias da Comunidade Kalunga dos municípios de Cavalcante, Teresina de Goiás e Monte Alegre, no Estado de Goiás, podem auxiliar tanto na avaliação de impactos quanto no planejamento de políticas de saúde locais, com respaldo dos indicadores gerados.

Sugere-se, neste sentido, o engendrar de esforços para que as ações de prevenção e promoção à saúde voltadas aos quilombolas sejam realizadas a partir da incorporação e avaliação de indicadores pertinentes, visando o monitoramento contínuo dos fatores antrópicos e ambientais que possam estar impactando nas condições de vida destas comunidades tradicionais.

As precárias condições de vida da comunidade estudada indicam a necessidade de programas específicos de tratamento, saneamento e educação, tanto domiciliares como peridomiciliares, que garantam melhorias da qualidade de vida dos moradores da comunidade. Tais programas devem atender não apenas o que é relativo às doenças, mas também aspectos que contemplem melhorias nas áreas de habitação e saneamento básico.

Há a premência de maior investimento frente ao provimento de água com qualidade para o abastecimento e consumo das residências Kalungas. Para tanto, é fundamental que haja fiscalização por parte das autoridades de vigilância sanitária em relação às fontes e formas de captação e armazenamento deste recurso, e, quiçá, futuramente, a ligação de todas as moradias Kalungas à rede pública de abastecimento garantindo o acesso a água de qualidade e em quantidade suficiente.

Evidencia-se a necessidade de melhoria das condições de saneamento básico, em especial, no que tange ao esgotamento sanitário que usualmente é feito por meio de fossas rudimentares ou lançado diretamente no solo. O uso direto ou indireto, do meio ambiente para destinação das eliminações pode facilitar a proliferação animais sinantrópicos e contaminação da água dos mananciais de superfície, prejudicando a qualidade da água destinada ao consumo humano e, consequentemente, a exposição a risco de veiculação hídrica. 
A capacitação de agentes ambientais e o fomento à adoção de ações de incentivo a preservação do meio ambiente, inclusive em relação à adequada destinação dos resíduos sólidos domiciliares, pode auxiliar na melhoria das condições de vida de moradores Kalungas.

É importante a inclusão de ações e medidas sanitárias específicas de controle das parasitoses, enfocando as formas de contaminação e disseminação entre grupos caracterizados pelo forte caráter de coletividade, como o observado entre os quilombolas, nos quais as probabilidades de infestação podem ser potencializadas devido ao convívio comunitário.

É recomendado, ainda, que se priorize a melhoria do acesso ao serviço de saúde e participação da comunidade em projetos de educação em saúde. $\mathrm{O}$ desenvolvimento de processos de educação em saúde deve basear-se no constante diálogo entre o saber tradicional e o saber científico norteador da problemática e das soluções, visando romper ciclos de transmissão de doenças e agravos e cooperando para a melhoria das condições de vida da população local.

Com relação à questão ambiental influenciada pela presença de fontes antrópicas de contaminação do bioma Kalunga por mercúrio (área exposta aos riscos da garimpagem não regulamentada), a partir dos resultados obtidos sugere-se a monitorização do mercúrio total e do metilmercúrio em amostras de cabelo e estudos de natureza clínico-epidemiológico nas áreas do Sítio Histórico e Patrimônio Cultural Kalunga, com vistas à implantação de medidas de controle da contaminação e prevenção de possíveis danos causados pelo metilmercúrio, tanto nos ecossistemas como na população.

Por fim, ressalta-se que, para o desenvolvimento de uma atenção integral e equânime voltada às comunidades de remanescentes quilombolas Kalungas, as ações e a organização do trabalho em saúde devem estar pautadas no conhecimento prévio dos elementos/fatores determinantes às condições de saúde e vida dos indivíduos e da comunidade, visando o incremento das possibilidades de intervir para a transformação de determinados DSS que representem aspectos negativos à saúde dessa população. 


\section{REFERÊNCIAS}




\section{REFERÊNCIAS}

1- Ministério da Saúde (BR). Secretaria de Políticas Públicas de Saúde. As cartas de promoção da saúde. Brasília: Ministério da Saúde, 2002.

2- Backes MTS, Rosa LM, Fernandes GCM, Becker SG, Meirelles BHS, Santos SMA. Conceitos de saúde e doença ao longo da história sob o olhar epidemiológico e antropológico. Rev Enferm UERJ. 2009 jan-mar;17(1):111-7.

3- Ferreira VA, Magalhães R. Nutrição e promoção da saúde: perspectivas atuais. Cad Saúde Pública. 2007 jul;23(7):1674-81.

4- Andrade LOM, Pontes RJS, Martins TA Jr. Descentralização no marco da Reforma Sanitária no Brasil. Rev panam salud pública. 2000 jul-ago;8(1-2):85-91.

5- Costa MR. A trajetória das lutas pela Reforma Sanitária. Sociedade em debate. 2007 juldez; 13(2):85-107.

6- Pereira C. A política pública como caixa de pandora: organização de interesses, processo decisório e efeitos perversos na Reforma Sanitária brasileira - 1985-1989. Dados rev ciênc sociais. 1996 abr;39(3):423-78.

7- Balsemão A. Competências e rotinas de funcionamento dos Conselhos de Saúde no Sistema Único de Saúde do Brasil. Brasil. Ministério da Saúde. Programa de Apoio ao Fortalecimento de Controle Social no SUS. Curso de extensão em direito sanitário para membros do Ministério Público e da Magistratura Federal. Brasília: Ministério da Saúde. 2002: p. 177-91.

8- Carvalho AI. Conselhos de saúde, responsabilidade pública e cidadania: a reforma sanitária como reforma do Estado. In Fleury S. Saúde e democracia: a luta do Cebes. São Paulo: Lemos Editorial; 1997: p. 93-112.

9- Fleury S. Reforma sanitária brasileira: dilemas entre o instituinte e o instituído. Cien Saúde Colet. 2009 mar;14(3):743-52.

10- Ministério da Saúde (BR). Fundação Osvaldo Cruz. Reforma Sanitária. Rio de Janeiro: Fiocruz, 2006. 
11- Vieira RCA; Souza AIS. Limites da operacionalidade. Physis. 2009 nov;19(4):1111-25.

12- Anais Conferência Nacional de Saúde VIII; 1986; Brasília [Relatório Final]. Conferência Nacional de Saúde. Brasília (DF): Ministério da Saúde, 1986.

13- Brasil. Constituição, 1988. Constituição da República Federativa do Brasil. Brasília (DF): Senado Federal, 1988.

14- Cutolo LRA. Modelo Biomédico, Reforma Sanitária e a educação pediátrica. ACM arq catarin med. 2006 jan;35(4):16-24.

15- Brasil. Lei n. ${ }^{\circ}$ 8.080, de 19 de setembro de 1990. [Lei Orgânica da Saúde]. Dispõe sobre as condições para a promoção, proteção e recuperação da saúde, a organização e o funcionamento dos serviços correspondentes e dá outras providências. Publicada no Diário Oficial da União - DOU. 20 set 1990; Seção 1:018055. Brasília (DF); 1990.

16- Verdi M, Caponi S. Reflexões sobre a promoção da saúde numa perspectiva bioética. Texto \& contexto enferm. 2005 jan-mar;14(1):82-8.

17- Carta de Fortaleza. [Texto apresentado ao I congresso de secretários municipais de saúde das Américas, Fortaleza, 13 de Outubro de 1995]. Divulg saúde debate. 1995 out;42(1):77-8.

18- Laurell AC. Impacto das políticas sociais e econômicas nos perfis epidemiológicos. In: Barradas R, et al, editores. Eqüidade e saúde: contribuições da epidemiologia. Rio de Janeiro: Fiocruz; 1997. p. 83-101.

19- Minayo MC de S. Enfoque ecossistêmico de saúde e qualidade de vida. In: Minayo MC de S, Miranda AC, editores. Saúde e ambiente sustentável: estreitando nós. Rio de Janeiro: Fiocruz; 2002. p. 173-87.

20- Granziera MLM, Dallari SG. Direito Sanitário e Meio Ambiente. In: Philippi A Jr, Alves AC, editores. Curso interdisciplinar de direito ambiental, Barueri (SP): Manole, 2005; 607 p.

21- Batistella C. Abordagens contemporâneas do conceito de saúde. In: Fonseca AF. O território e o processo saúde doença. Coleção educação profissional e docência em saúde. A formação e o trabalho do agente comunitário. Rio de Janeiro: Fiocruz; 2007. p. 51-86. 
22- Macedo H. Saneamento e Saúde - Um estudo de caso da Vila Roriz, em Goiânia/Goiás. [dissertação de mestrado]. Brasília: Instituto de Ciências Humanas, Departamento de Geografia, Universidade de Brasília; 2008.

23- Tambellini AT, Câmara VM. A temática saúde e ambiente no processo de desenvolvimento do campo da saúde coletiva: aspectos históricos, conceituais e metodológicos. Ciênc saúde coletiva. 1998 abr-jun;3(2):47-59.

24- Câmara V de M, Galvão LAC. A patologia do trabalho numa perspectiva ambiental. In: Mendes R, editor. A Patologia do Trabalho. São Paulo: Editora Atheneu, 1995. p. 165-75.

25- Augusto LG da S. Saúde e vigilância ambiental: um tema em construção. Epidemiol serv saúde. 2003 dez;12(4):177-87.

26- Organização Mundial da Saúde, Organização Pan-Americana da Saúde. Atenção Primária Ambiental. Brasília (DF): Gráfica e Ed. Brasil, 2000.

27- Sant'anna CF, Cezar-Vaz MR, Cardoso LS, Erdmann AL. Determinantes sociais de saúde: características da comunidade e trabalho das enfermeiras na saúde da família. Rev gaúch enferm. 2010 jan;31(1):92-9.

28- Ministério da Saúde (BR). Sistema Nacional de Vigilância Ambiental em Saúde. Brasília, DF: Fundação Nacional da Saúde, 2001.

29- Lopes KCSA, Borges JRP, Lopes PR. Condições de vida e qualidade do saneamento ambiental rural como fator para o desenvolvimento de práticas agroecológicas. Rev bras de agroecologia. 2012 jan;7(1):39-50.

30- Saiani CCS, Toneto R Jr. Evolução do acesso a serviços de saneamento básico no Brasil 1970 a 2004. Rev. econ e sociedade. 2010 abr;19(1):79-106.

31- Azeredo CM, Cotta RMM, Schott M, Maia T de M, Marques ES. Avaliação das condições de habitação e saneamento: a importância da visita domiciliar no contexto do Programa de Saúde da Família. Ciênc saúde coletiva. 2007 dez;12(3):743-53.

32- Barcellos CMM, Rodrigues L dos S, Costa CC, Oliveira PR, Silva I, Jesus EFM, Rolim RG. Avaliação da qualidade da água e percepção higiênico-sanitária na área de Lavras, Minas Gerais, Brasil, 1999-2000. Cad saúde pública. 2006 jan;22(9):1967-78. 
33- Costa SS, Heller L, Brandão CCS, Colosimo EA. Indicadores epidemiológicos aplicáveis a estudos sobre a associação entre saneamento e saúde de base municipal. Rev eng sanit e ambiental. 2005 abr-jun;10(2):119-27.

34- Franco Netto G, Freitas CM, et al. Impactos socioambientais na situação de saúde da população brasileira: Estudo de indicadores relacionados ao saneamento ambiental inadequado. Rev tempus. 2009 dez;3(4):53-71.

35- Lermen HS, Fisher PD. Percepção ambiental como fator de saúde pública em áreas de vulnerabilidade social no Brasil. Revista de APS. 2010 jan-mar;13(1):62-71.

36- Neiva ACGR, Sereno JRB, Fiorivani MCS. Indicação geográfica na conservação e agregação de valor ao gado curraleiro da comunidade kalunga. Archivos de zootecnia. 2011 jan;60(231):357-60.

37- Custódio HB. Legislação ambiental no Brasil. Rev de direito civil: Imob agrário e empresarial. 1996 abr-jun;76(1):56-71.

38- Motter DG, Alves JM de. Construção do princípio de integralidade: percepções e ações desencadeadas pela equipe de saúde da família quanto às demandas sociais apresentadas no município de Londrina-PR. Serviço soc em revista. 2006 jan-jun; 8(2):154-65.

39- Seild EMF, Zannon CML da C. Qualidade de vida e saúde: aspectos conceituais e metodológicos. Cad saúde pública. 2004 mar-abr; 20(2):580-8.

40- Buss PM, Pellegrini Filho AA. A saúde e seus determinantes sociais. Physis (Rio J). 2007 jan, 17(1):77-93.

41- Comissão Nacional sobre os Determinantes Sociais da Saúde (CNDSS). Carta aberta aos candidatos à Presidência da República. Brasília; 2006. [acesso em 2014 mar 15]. Disponível em: www.determinantes.fiocruz.br.

42- Machado MFAS, Monteiro EMLM, Queiroz DT, Vieira NFC, Barroso MGT. Integralidade, formação de saúde, educação em saúde e as propostas do SUS: uma revisão conceitual. Ciênc saúde coletiva. 2007 dez;12(2):335-42. 
43- Buss PM, Pellegrini A Filho. Iniquidades em saúde no Brasil, nossa mais grave doença: comentários sobre o documento de referência e os trabalhos da Comissão Nacional sobre Determinantes Sociais da Saúde. Cad. saúde pública. 2006 set;22(9):2005-8.

44- Whitehead M. The concepts and principles of equity in health. Intern journal of health services.1992 jul;22 (3):429-45.

45- Cotta RMM, Gomes AP, Maia T de M, Magalhães KA, Marques ES, Batista RS. Pobreza, injustiça, e desigualdade social: repensando a formação de profissionais de saúde. Rev bras educ méd. 2007 dez; 31(3), 278-86.

46- Siqueira-Batista R, Schramm FR. A saúde entre a iniquidade e a justiça: contribuições da igualdade complexa de Amartya Sen. Ciênc saúde coletiva. 2005 jan;10(1):129-42.

47- Assis AMO, Barreto ML, Santos NS, Oliveira LPMD, Santos SMCD, Pinheiro SMC. Desigualdade, pobreza e condições de saúde e nutrição na infância no nordeste brasileiro. Cad saúde pública. 2007 ago;23(10):2337-50.

48- Teixeira JC, Gomes MHR, Souza JA. Análise da associação entre saneamento e saúde nos estados brasileiros - estudo comparativo entre 2001 e 2006. Rev eng sanit e ambiental. 2011 abr-jun;16(2):197-204.

49- Briscoe J, Feachem RG, Rahaman MM. Evaluation Health Impact. Water Supply, Sanation and Hygiene Education. Ottawa: IDRC, 1986.

50- Heller L. Relação entre saúde e saneamento na perspectiva do desenvolvimento. Ciênc saúde coletiva. 1998 jun;3(2):73-84.

51- Teixeira JC, Heller L. Fatores ambientais associados à diarreia infantil em áreas de assentamento subnormal em Juiz de Fora, Minas Gerais. Rev bras saúde matern infant. 2005 dez;5(4):449-55.

52- IBGE - Instituto Brasileiro de Geografia e Estatística (BR). Pesquisa Nacional de Saneamento Básico, 2008. Rio de Janeiro: IBGE, 2010.

53- Beheregaray LR, Gerhardt TE. A integralidade no cuidado à saúde materno-infantil em um contexto rural: um relato de experiência. Rev saúde soc. 2010 mar;19(1): 201-12. 
54- Freitas DA, Caballero AD, Marques AS, Hernández CIV, Antunes, SLNO. Saúde e comunidades quilombolas: uma revisão da literatura. Rev CEFAC. 2011 set-out; 13(5):93743.

55- Tibúrcio BA, Valente ALEF. O Comércio justo e solidário é a alternativa para segmentos populacionais empobrecidos? Estudo de caso em território Kalunga (GO). Rev econ sociol rural. 2007 abr-jun;45(2):497-519.

56- Magalhães NA, Koyanagi R. Rancho Kalunga no Vão de Almas. Revista RDP. 2013 jan;1(1):198-201.

57- Ribeiro JW, Rooke JMS. Saneamento Básico e sua relação com meio ambiente e saúde Pública. [trabalho de conclusão de curso de especialização]. Juiz de Fora: Universidade Federal de Juiz de Fora; 2010. [acesso em 2014 fev 10]. Disponível em: www.ufjf.br/analiseambiental

58- Vieira ABD, Monteiro PS. Comunidade quilombola: análise do problema persistente do acesso à saúde, sob o enfoque da Bioética de Intervenção. Divulg saúde debate. 2013 outdez;37(99):610-8.

59- World Health Organization. Bangkok charter for health promotion in the globalizeted world. Geneve: WHO; 2005. [acesso 2013 Jul 23]. Disponível em: http://www.who.int/helthpromotion/conferences/6gchp/hpr_050829_\%20BCHP.pdf

60- Organización Panamericana de La Salud. Protección Ambiental. XXIII Conferencia Sanitaria Panamericana. XLII Reunión del Comité Regional (CPS23/16). 1990. OPS, Washington, DC, mimeo.

61- Cohn A. Caminhos da Reforma Sanitária. Rev lua nova. 1989 jan;19(1):123-40.

62- Stotz EN. Movimentos sociais e saúde: notas para uma discussão social. Cad saúde pública. 1994 jan;10(2):264-8.

63- Fernandes AJC. Origens do Movimento Sanitário Brasileiro. [trabalho de conclusão de curso de especialização]. Brasília: Departamento de Sociologia, Universidade de Brasília; 2011. 
64- Paim JS. Reforma sanitária brasileira: contribuição para compreensão e crítica. [tese de doutorado]. Salvador: Programa de Pós Graduação em Saúde Coletiva, Instituto de Saúde Coletiva, Universidade Federal da Bahia; 2007.

65- Paulus A Jr, Cordoni L Jr. Políticas públicas e saúde no Brasil. Rev espaço saúde. 2006 dez; 8(1):13-9.

66- Cordoni L Jr. Serviços municipais de saúde no Paraná: tendências e perspectivas. [tese de doutorado]. São Paulo: Faculdade de Saúde Pública, Universidade de São Paulo; 1986.

67- Paim JS, Travassos C, Almeida C, Bahia L, Macinko J. O sistema de saúde brasileiro: história, avanços e desafios. Série Saúde no Brasil, fascículo 1. The Lancet. 2011 maio 11. [acesso 2012 dez 13]. Disponível http://download.thelancet.com/flatcontentassets/pdfs/brazil/brazilpor1.pdf

68- Lana FCF, Gomes ELR. Reflexões sobre o planejamento em saúde eo processo da reforma sanitária brasileira. Rev latinoam enferm. 1996 jan;4(1):97-110.

69- Almeida CM. Os modelos de reforma sanitária dos anos 80: Uma análise crítica. Rev saúde soc. 1996 jan;5(1): 3-57.

70- Fleury S. A Reforma Sanitária brasileira. In: Berlinguer G, Teixeira S, Campos G, editores. Reforma sanitária: Itália e Brasil. São Paulo: Hucitec-CEBES, 1988. p. 179-94.

71- Santos L. Distribuição de competências no Sistema Único de Saúde: o papel do Estado nas três esferas de governo no SUS. Brasília: OPS/OMS, 1994.

72- Santos G de Q. Estratégia na luta pela saúde: a experiência no do Conselho Municipal do Rio de Janeiro. [dissertação de mestrado]. Rio de Janeiro: Escola de Serviço Social, Universidade Federal do Rio de Janeiro, 2004.

73- Paim JS. Bases conceituais da Reforma Sanitária Brasileira. In: Fleury S. Saúde e democracia: a luta do CEBES. São Paulo: Lemos Editorial, 1997. p. 125-41.

74- Vaitsan J. Corporativismo: notas para a sua aplicação no campo da saúde. In: Teixeira S., editor. Reforma sanitária: em busca de uma teoria. São Paulo: Cortez,1989. p. 139-56. 
75- Tanaka OY, Escobar EMA, Gimenez ASM, Camargo KG, Lelli CL, Yoshida TM. Gerenciamento do setor saúde na década de 80, no Estado de São Paulo, Brasil. [Publicação financiada pela FAPESP]. São Paulo: Processo Saúde Coletiva. 1992 jun; 91(1): 494-500.

76- Ministério da Previdência e Assistência Social (BR). Reorientação da assistência à saúde no âmbito da previdência social. Brasília, 1983.

77- Bossert T, Larrañaga O, Meir FR. Descentralizacion of health systems in Latin America. Rev panam salud pública. 2000 jan;1(2):84-92.

78- Souza RR. O sistema público de saúde brasileiro. Seminário Internacional Tendências e Desafios dos Sistemas de Saúde nas Américas. São Paulo, 2002.

79- Nogueira VMR, Mioto RCT. Desafios atuais do Sistema Único de Saúde - SUS e as exigências para os assistentes sociais. Rev. serv social saúde. 2006 jan;1(1):218-41.

80- Florentino M. Em costas negras. Uma história do tráfico de escravos entre a África e o Rio de Janeiro. São Paulo: Companhia das letras, 1997.

81- Berute GS, Osório H. O tráfico de almas: uma análise do tráfico negreiro na capitania do Rio Grande de São Pedro do Sul (1788-1819). In: Anais do $13^{\circ}$ Salão de Iniciação Científica, 2001; Porto Alegre: UFRGS; 2001. p. 133-50.

82- Reis JJ, Gomes F dos S. Liberdade por um fio: história dos quilombos no Brasil. São Paulo: Companhia das letras, 1996.

83- Munanga K. Origem e histórico do quilombo na África. Rev USP. 1996 fev;28:58-63.

84- Carril L de FB. Quilombo, território e geografia. Rev Agrária São Paulo, 2006 jan;3(1):156-71.

85- Schmitt A, Turatti M, Carvalho MCPD. A atualização do conceito de quilombo: identidade e território nas definições teóricas. Ambient soc. 2002 jan;10(1):1-10.

86- Moura C. Rebeliões na senzala, quilombos, insurreições, guerrilhas. São Paulo: Ciências humanas, 1981.

87- Leite IB. O projeto político quilombola: desafios, conquistas e impasses atuais. Rev est fem. 2008 set;16(3):965-77. 
88- Secretaria de Políticas de Promoção da Igualdade Racial. Programa Brasil Quilombola [Internet]. Brasília; 2013. [acesso em 20013 Set 12]. Disponível em: www.portaldaigualdade.gov.br

89- Carneiro E. O quilombo dos Palmares. São Paulo: Martins fontes, 2011.

90- Silva JAND. Condições sanitárias e de saúde em Caiana dos Crioulos, uma comunidade quilombola do estado da Paraíba. Rev saúde soc, 2007 jun;16(2):111-24.

91- Leite IB. Os quilombos no Brasil: questões conceituais e normativas. Rev etnográfica. 2000 jul;4(2):333-54.

92- Aruti JMA. As comunidades negras rurais e suas terras: a disputa em torno de conceitos e números. Rev dimensões. 2002 jan;14(1):243-69.

93- Brasil. Fundação Cultural Palmares. Sistema de informações de comunidades afrobrasileiras: SICAB; 2007 [acesso 2013 Set 24]. Disponível em: www.palmares.gov.br

94- Chasin ACDM. 20 anos de regularização fundiária de territórios quilombolas: um balanço da implementação do direito à terra estabelecido pela Constituição Federal de 1988. Rev política hoje, 2010 mai; 18(2):158-83.

95- Anjos RSA, Cipriano A. As comunidades no território nacional. In: Anjos RSA, Cipriano A, editores. Quilombolas. Tradições e cultura da resistência. São Paulo: Aori Comunicação, 2007. p. 176-206.

96- Baiocchi M de N. Kalunga: povo da terra. Goiânia: UFG, 2006.

97- Ministério da Educação. Uma história do povo Kalunga. Brasília: Secretaria de Educação Fundamental - MEC; 2011.

98- Almeida MG. Dilemas territoriais e indenitários em sítios patrimonializados: os Kalunga de Goiás. In: Castilho DP. Cerrados: perspectivas e olhares. Goiânia: Vieira, 2010.

99- Karasch M. Os quilombos do ouro na Capitania de Goiás. In: Reis JJ, Gomes F dos S, editores. Liberdade por um fio: história dos quilombos no Brasil. São Paulo: Companhia das letras, 1996. p. 240-62. 
100- Jatobá D. Comunidade Kalunga e a interpelação do estado: da invisibilidade a identidade política. [dissertação de mestrado]. Brasília: Departamento de Antropologia, Universidade de Brasília, 2002.

101- Neiva ACGR. Caracterização socioeconômica da comunidade quilombola kalunga e proposta de reintrodução do bovino curraleiro como alternativa de geração de renda. [tese de doutorado]. Goiânia: Escola de Veterinária, Universidade Federal de Goiás, 2009.

102- Soares AA. Kalunga: o direito de existir. Brasília: Ministério da Cultura, Fundação Palmares; 1995.

103- Lima LNM de. A constituição de um território identitário gela garantia dos direitos fundiários: o Sítio Histórico e Patrimônio Cultural Kalunga. Rev soc \& natureza. 2013 jul;25(3):503-12.

104- Andrade L, Trecanni G. Terras de quilombo. In: Laranjeira R, editor. Direito agrário brasileiro. São Paulo: LTr, 2000.

105- Associação Brasileira de Antropologia. Boletim informativo: documento do grupo de trabalho sobre comunidades negras rurais. Florianópolis: ABA, 1994. p. 81-2.

106- Goiás. Lei n. ${ }^{\circ} 11.409$ de 21 de janeiro de 1991. Dispõe sobre o Sítio Histórico e Patrimônio Cultural que especifica. Publicada no Diário Oficial do Estado Goiânia. 28 jan 1991. Goiania (GO); 1991.

107- Almeida MG. Territórios de quilombolas: pelos vãos e serras dos Kalunga de Goiás patrimônio e biodiversidade de sujeitos do cerrado. Ateliê geográfico; 2011 fev;4(1):36-63.

108- Arruti JM. Mocambo: antropologia e história do processo de formação quilombola. Bauru (SP): Edusc, 2006.

109- Secretaria Especial de Políticas de Promoção da Igualdade Racial (SEPPIR), Fundação Universidade de Brasília (FUBRA). Perfil das Comunidades Quilombolas - Alcântara, Ivaporunduva e Kalunga. Brasília: SEPPIR, 2004.

110- Khan AS, Silva LMR. Eficácia e evolução dos indicadores socioeconômicos de famílias beneficiadas pelo programa de combate à pobreza rural: Projeto São José no Estado do Ceará. Rev bras soc econ rural. 2007 set;45(4):1037-53. 
111- Anjos RSA, Cypriano A. Quilombolas: tradições e cultura de resistência. São Paulo: Aori Comunicação, 2006.

112- Marinho TA. Identidade e reconhecimento: nexos, práticas e consumo entre os Kalunga. Rev latitude. 2008 abr;2(2):123-42.

113- Silva OS. Quilombos do sul do Brasil: movimento social emergente na sociedade contemporânea. Rev identidade 2010 fev;15(1):51-64.

114- Sant'Anna CF, Cezr-Vaz MR, Cardoso LR, Erdmann AL, Soares JFS. Determinantes sociais de saúde: características da comunidade e trabalho das enfermeiras na saúde da família. Rev gaúch enferm. 2010 mar;31(1):02-9.

115- Krieger N. A glossary for social epidemiology. J epid com health. 2001 fev;53(1):693700.

116 - Rosen G. Da polícia médica à medicina social. Rio de Janeiro: Graal, 1980.

117 - Almeida Filho N. Research on health inequalities in Latin America and the Caribbean: Bibliometricanalisys (1971-2000) and descriptive content analysis (1971-1995). Am j public health. 2003 mar;93(1):2037-43.

118- Adler N. Behavioral and social sciences research contributions. In: NIH Conference on Understanding and Reducing Disparities in Health [internet]; 2006 outubro 23-24. NIH Campus, Bethesda, Maryland. [acesso 20014 fev 13]. Disponível em: http://obssr.od.nih.gov/HealthDisparities/presentation.html

119- Dahlgren G, Whitehead M. Policies and strategies to promote social equity in health. Stockholm: Institute for Future Studies, 1991.

120- Badziak RPF, Moura VEV. Determinantes sociais da saúde: um conceito para efetivação do direito à saúde. Rev saúde pública Santa Catarina, 2010 jan;3(1):69-79.

121- Rose G. The strategy of preventive medicine. Oxford: Oxford University Press, 1992.

122- Pellegrini Filho A. Compromisso com a ação. RADIS dados, 2006 jul;47(1):12-4. 
123- Gama D. Closing the gap in a generation: health equity through action on the social determinants of health. Final report of the Commission on Social Determinants of Health. Rev direito sanitário. 2010 jan;10(3):253-66.

124- Commission on Social Determinantsof Health (CSDH). A conceptual framework for action on social determinants of health. [acesso 2013 jul 10]. Disponível em: www.determinantesfiocruz.br

125- Ribeiro H. Saúde pública e meio ambiente: evolução do conhecimento e da prática, alguns aspectos éticos. Rev saúde soc. 2004;13(1):70-80.

126- Alonzo HGA, Cabral AR, Bueno PC, Louvandini P, Lima E, Santos SCM, Leite CMB, Buosi D, Netto GF. O Subsistema Nacional de Vigilância em Saúde Ambiental (SINVSA) e seus desafios. In I Conferência Nacional de Saúde Ambiental, 2009. Brasília (DF); 2009.

127- Leff E. Epistemologia ambiental. São Paulo: Cortez; 2002.

128- Brasil. Ministério da Saúde. Secretaria de Vigilância em Saúde. Instrução Normativa n. ${ }^{\circ} 1$, de 07 de março de 2005. Brasília, 2005.

129- Brasil. Lei n. ${ }^{\circ} 11.445$, de 05 de janeiro de 2007. Dispõe sobre o estabelecimento de diretrizes nacionais para o saneamento básico; altera as Leis $n .^{\circ} 6.766$, de 19 de dezembro de 1979, 8.036, de 11 de maio de 1990, n. ${ }^{\circ} 8.666$, de 21 de junho de 1993, n. ${ }^{\circ} 8.987$, de 13 de fevereiro de 1995; revoga a Lei n. ${ }^{\circ}$ 6.528, de 11 de maio de 1978; e dá outras providências. Publicada no Diário Oficial da União - DOU. 05 set 2007. Brasília (DF); 2007.

130- Lima AMC. Indicadores sanitário-ambientais: classificação de bacias de esgotamento sanitário e micro-áreas na cidade de Salvador - BA. [dissertação de mestrado]. Salvador: Faculdade de Medicina da Bahia, Universidade Federal da Bahia, 2008.

131- Souza CMN, Freitas MC. O saneamento na ótica da prevenção de doenças e da promoção da saúde. [anais eletrônicos]. In: Anais do XXX Congresso Interamericano de Ingenieria Sanitária y Ambiental; 2006; Puntadel Leste. Punta del Leste: AIDIS; 2006. 
132- Souza CMN, Freitas, CM, Moraes LRS. Discursos sobre a relação saneamento-saúdeambiente na legislação: uma análise de conceitos e diretrizes. Eng sanitaria ambien. 2007 dez;12(4):371-9.

133 - Cezarina MNS. A relação saneamento-saúde-ambiente: um estudo sobre discursos setoriais na perspectiva da promoção da saúde e da prevenção de doenças. [tese de doutorado]. Rio de Janeiro: Escola Nacional de Saúde Pública Sérgio Arouca (ENSP), 2007.

134- Chaves AM, Horizonte B. Condições sanitárias na terra indígena Xakriabá - MG: associação com indicador de saúde por meio de estudo epidemiológico transversal. [dissertação de Mestrado]. Belo Horizonte: Programa de Pós-graduação em Saneamento, Meio Ambiente e Recursos Hídricos, Universidade Federal de Minas Gerais, 2004.

135- Instituto Brasileiro de Geografia e Estatística (IBGE), Fundação Instituto Brasileiro de Geografia e Estatística. Pesquisa nacional por amostra de domicílios, 1999 [CD-ROM]. Rio de Janeiro: IBGE, 2000.

136- Saiani CCS. Déficit de acesso aos serviços de saneamento básico no Brasil. Prêmio IPEA- CAIXA 2006, Brasília, 2006.

137- Phillippi Jr A, editor. Saneamento, Saúde e Ambiente. Barueri (SP): Manole; 2005.

138- Ministério da Saúde, Organização Pan-Americana da Saúde. Avaliação de impacto na saúde das ações de saneamento: marco conceitual e estratégia metodológica. Brasília (DF): Ministério da Saúde, 2004.

139- D’Aguila OS, Roque OC da C, Miranda CAS, Ferreira AP. Avaliação da qualidade de água para abastecimento público do município de Nova Iguaçu. Cad saúde pública. 2000 jul;16(3):791-8.

140- Grabow W. Waterborne diseases: update on water qualityassessment and control. Water SA. 1996 mar; 22(1):193-202.

141- Rouquayrol, MZ. Mecanismos de Transmissão de doenças. $6^{\mathrm{a}}$ ed. Fortaleza: Medsi; 2003.

142- World Health Organization - WHO. Guide lines for Drinking - Water Quality. Genova, 1996. 
143- Cairncross S, Fechem RG. Environmental health engineering in the tropics: an introductory text. Chichester: John Wiley \& Sons; 1990.

144- Heller L. Saneamento e saúde. Brasília: OPAS/OMS, 1997.

145- Brasil. Fundação Nacional de Saúde. Manual de Saneamento. $3^{\mathrm{a}}$ ed. Brasília: Funasa, 2004

146- Stukel TA, Greenberg ER, Dain BJ, Reed FC, Jacobs NJ. A longitudinal study of rainfall and coliform contamination in small community drinking watersupplies. Environ sci technol. 1990 mar;24(1):571-5.

147- Do Amaral LA, Nader A Filho, Rossi OD Jr, Ferreira FLA, Barros LSS. Água de consumo humano como fator de risco à saúde em propriedades rurais. Rev saúde pública. 2003 out;37(4):510-4.

148- Sant’anna CF, Cezar-Vaz MR, Cardoso LS, Erdmann AL, Soares JFS. Os determinantes sociais da saúde: características da comunidade e trabalho do enfermeiro na atenção à saúde da família. Rev gauch Enferm. 2010 fev; 31(1):92-9.

149- Ferreira UM, Ferreira CS, Monteiro CA. Tendência secular das parasitoses intestinais na infância na cidade de São Paulo. Rev saude pública. 2000 jun;34(6):73-82.

150- Cooper ES, Whyte-Alleng CAM, Finzi-Smith JS. Intestinal nematode infections in children: the pathophysiological price paid. Parasitology. 1992 abr;104(1):91-103.

151- Justino GDO, Janebro DI, Ferreira ADM, Nóbrega MDFF, Queiroz MDRSD. Identificação e tratamento de endoparasitoses em pacientes da terceira idade. Rev boletim FIEP. 2010 jun;80(2):60-9.

152- Borges WF, Marciano FM, Oliveira HB. Parasitos intestinais: elevada prevalência de Giardia lamblia em pacientes atendidos pelo serviço público de saúde da região sudeste de Goiás, Brasil. Rev parasit tropical. 2011 ago; 40(2):149-57.

153- Carneiro M, Antunes CMF. Epidemiologia: introdução e conceitos. In: Neves DP, Melo AL, Genaro O, Linardi PM, editores. Parasitologia humana. $10^{\mathrm{a}}$ ed. São Paulo: Atheneu; 2000. p. 10-20. 
154- Chieffi PP, Amato V Neto. Vermes, verminoses e a saúde pública. Ciênc cult. 2003 jan; $55(1): 41-3$.

155- Harpham T, Stephens C. Urbanization and health in developing countries. World health Statistic Quarterly. 1991 abr;44(1):62-9.

156- Prado MS, Barreto ML, Strina A, Faria JAS, Nobre AA, Jesus SR. Prevalência e intensidade da infecção por parasitos intestinais em crianças na idade escolar na cidade de Salvador (Bahia, Brasil). Rev soc bras med trop. 2001 fev;34(1):99-101.

157- Falavigna-Guilherme AL, Aráujo SM, Pupulin ART, Lima Júnior JE, Falavigna DLM. Parasitos intestinais e comensais em indivíduos de três vilas rurais do Paraná, Brasil. Acta sci. 2004 mai;26(2):331-6.

158- Frei F, Juncansen C, Ribeiro-Paes JTR. Levantamento epidemiológico das parasitoses intestinais: viés analítico decorrente do tratamento profilático. Cad saúde pública. 2008 dez; 24(12):219-25.

159- Belloto MVT, Santos Junior JE, Macedo EA, Ponce A, Galisteu KJ, Castro E, et al. Enteroparasitoses numa população de escolares da rede pública de ensino do município de Mirassol, São Paulo, Brasil. Rev pan-amaz saude. 2011 mar;2(1):37-44.

160- Fonseca EO, Teixeira MG, Barreto ML, Carmo EH, Costa MCN. Prevalência e fatores associados a infecções por geo-helmintos em crianças que vivem em municípios com baixo IDH no norte e nordeste do Brasil. Cad saúde pública. 2010 jan;26(1):143-52.

161- Andrade EC, Leite IG, Rodrigues IO, Cesca MG. Parasitoses intestinais: uma revisão sobre seus aspectos sociais, epidemiológicos, clínicos e terapêuticos. Rev APS. 2010 mai;13(2):231-40.

162- Araújo KCS. Borges JPR. Condições de vida e qualidade do saneamento ambiental rural como fator para o desenvolvimento de práticas agroecológicas. Rer bras agroecologia. 2012 jan;7(1):39-50.

163- Barrocas PR, Wasserman JC. O mercúrio na Baía de Guanabara: uma revisão histórica. Geochimica brasiliensis. 1995 ago; 9(2):115-27. 
164- Tsutiya MT. Metais pesados: o principal fator limitante para o uso agrícola de biossólidos das estações de tratamento de esgotos. In: Congresso Brasileiro de Engenharia Sanitária e Ambiental, 1999; Rio de Janeiro: ABES; 1999. p.753-61.

165- Souza JR, Barbosa AC. Contaminação por mercúrio e o caso da Amazônia. Quím nova escola. 2000 nov; 12(1):3-7.

166- Farias, LA, dos Santos NR, Favaro DI, Braga, ES. Mercúrio total em cabelo de crianças de uma população costeira, Cananéia, São Paulo, Brasil. Cad saúde pública. 2008 out;24(10): 2249-56.

167- Rodrigues RM, Mascarenhas AFS, Ichiara AH, Souza TMC, Bidone JB Filho BS. Introdução. In: Bidone ED, Rodrigues RM, editores. Estudo dos impactos ambientais decorrentes do extrativismo mineral e poluição mercurial no Tapajós: Pré-Diagnóstico. Rio de Janeiro: Cetem/CNPq, 1994. p. 1-28.

168- Mergler D, Henry A, Anderson HA, Chan HM, Mahaffey KR, Michael MM, Sakamoto M, Stern AH. Methylmercury exposure and health effects in humans: a worldwide concern. Rev ambio. 2007 jan; 36(1):3-11.

169- Farias LA, Fávaro DIT, Vasconcelos MBA. Determinação de mercúrio e metilmercúrio em amostras de cabelo e peixes. Rev. Inst. Adolfo Lutz. 2009 dez;68(3):451-60.

170- Brabo E da S, Santos E de S, Jese IM, Mascarenhas AF, Faial KF. Níveis de mercúrio em peixes consumidos pela comunidade indígena de Sai Cinza na reserva Munduruku, município de Jacareacanga, Estado do Pará, Brasil. Cad saúde pública. 1999 jun;15(2):32531.

171- Mauro JBN, Guimarães JRD, Melamed R. Mercury methylation in a tropical macrophyte: influence of abiotic parameters. Organometallic Chemistry. 1999 jan;13 (1):1-6.

172- Azevedo FA. Toxicologia do mercúrio. São Carlos (SP): Rima; 2003.

173- Fitzgerald WF, Mason RP. Biogeochemical cyeling marine environment. In: Sigel A, Sigel H, organizadores. Metals in biological systems: mercury and its effects on environment and biology. New York: Marcel Dekker; 1997. p. 53-111. 
174- Farias LA. Avaliação do conteúdo de mercúrio, metilmercúrio e outros elementos de interesse em peixes e em amostras de cabelos e dietas de pré-escolares da região amazônica. [tese de doutorado] São Paulo: Universidade de São Paulo, 2006.

175- Micaroni RCC, Bueno MIMS, Jardim WF. Compostos de mercúrio: revisão de métodos de determinação, tratamento e descarte. Químca nova, 2000 dez;23(4):487-95.

176- Silva AM. Toxicologia do mercúrio no meio ambiente. São Paulo: Cered; 1951.

177- Peterson CL, Klawe WL, Sharp GD. Mercury in tunas: a review. Fishery bulletin. 1973 jul;71(3): 603-13.

178- Morgano MA, Gomes PC, Mantovani DM, Perrone AA, Santos TF. Níveis de mercúrio total em peixes de água doce de pisciculturas paulistas. Ciênc tecnol aliment, 2005 abr;25(2):250-3.

179- Roulet M, Guimarães JRD, Rheault I. Methylmercury in water, seston and epiphytonosf an Amazonian river and its flooplain, Tapajós River, Brazil. Rev elsevier, 2000 abr;261(1):43-59.

180- Gardfeldt K, Munthe J, Stromberg D, Lindqvist OA. Kinetic study on the abiotica methylation of divalent mercury in the aqueous phase. Rev elsevier, 2003 fev;304(1):127-136.

181- Pereira MG. Epidemiologia: teoria e prática. Rio de Janeiro: Guanabara Koogan; 2010.

182- Andrade MM. Métodos e técnicas de pesquisa. Introdução à metodologia do trabalho científico. $9^{\underline{a}}$ ed. São Paulo: Atlas; 2009.

183- Baiocchi MN. Kalunga: povo da terra. Brasília: Ministérios da Justiça, Secretaria de Estado dos Diretos Humanos, 1999.

184- Pedrosa MAF. Composição genética de quatro populações remanescentes de quilombos no Brasil com base em microssatélites e marcadores de ancestralidade. [dissertação de mestrado]. Brasília: Pós-Graduação em Biologia Molecular, Instituto de Ciências Biológicas, Universidade de Brasília, 2006. 
185- Instituto Brasileiro do Meio Ambiente e dos Recursos Renováveis (IBAMA). IBAMA: ecossistemas brasileiros - cerrado [internet]. Brasília: Ibama; 2007. [acesso 2014 abril 10]. Disponível em: http://ibama.gov.br

186- Marinho TA. Identidade e territorialidade entre os kalungas do Vão do Moleque. [dissertação de mestrado]. Goiás: Programa de Pós-Graduação em Sociologia, Universidade Federal de Goiás, 2008.

187- Moura MI, Torres TF, Monteiro EP, Neiva ACGR, Cardoso WS, Fioravanti MC. Evolução de um rebanho de bovinos curraleiro reintroduzido em cerrado nativo na região nordeste do estado de Goiás, Brasil. AICA. 2013 jan;1(1),123-6.

188- Instituto Brasileiro de Geografia e Estatística (IBGE). Censo demográfico. Sinopse do censo demográfico 2010 de Cavalcante (GO), 2010. [internet]. Brasília: IBGE, 2010. [acesso 2013 novembro 10]. Disponível em: http://www.informacoesdobrasil.com.br/dados/goias/cavalcante/sinopse-censo-demografico2010

189- Instituto Brasileiro de Geografia e Estatística (IBGE). Censo demográfico. Sinopse do censo demográfico 2010 de Teresina de Goiás (GO), 2010. [internet]. Brasília: IBGE, 2010. [acesso 2013 novembro 10]. Disponível em: http://www.informacoesdobrasil.com.br/dados/goias/teresina-de-goias/sinopse-censodemografico-2010

190- Instituto Brasileiro de Geografia e Estatística (IBGE). Censo demográfico. Sinopse do censo demográfico 2010 de Monte Alegre de Goiás (GO), 2010. [internet]. Brasília: IBGE, 2010. [acesso 2013 novembro 10]. Disponível em: http://www.informacoesdobrasil.com.br/dados/goias/monte-alegre-de-goias/sinopse-censodemografico-2010

191- Correa SMBB. Probabilidade e estatística. $2^{\mathrm{a}}$ ed. Belo Horizonte: PUC Minas Virtual; 2006.

192- Oliveira TMV. Amostragem não probabilística: adequação de situações para uso e limitações de amostras por conveniência, julgamento e cotas. Rev adm. 2001 jul-set; 2(3):154-61. 
193- Marconi MA, Lakatos EM. Técnicas de pesquisa: planejamento e execução de pesquisas, amostragens e técnicas de pesquisa, elaboração, análise e interpretação de dados. $3^{\mathrm{a}}$ ed. São Paulo: Atlas; 1996.

194- Pranpero ACCM. Avaliação de impactos à saúde e ao meio ambiente provocados pelo mercúrio odontológico nas unidades básicas de saúde do município de Barra do Garças-MT. [dissertação de mestrado]. Goiania: Programa de Pós-Graduação em Ciências Ambientais e Saúde, Pró-reitoria de Pós-Graduação e Pesquisa, Pontifícia Universidade Católica de Goiás, 2012.

195- Polit DF, Hungker BP. Fundamentos da pesquisa em enfermagem. Porto Alegre: Artes Médicas; 1995.

196- Yin RK. Case Study Research: design and methods. USA: Sage Publications Inc, 1989.

197- Dezin N, Lincoln VS. O planejamento da pesquisa qualitativa: teorias e abordagem. $2^{\mathrm{a}}$ ed. Porto Alegre: Artmed; 2006.

198- Vieira S. Introdução à bioestatística. $3^{\text {a }}$ ed. Rio de Janeiro: Campus, 2001.

199- American Public Health Association. Standard methods for the examination of water and wastewater. Washington (DC): 20 th Ed; 1998. p. 9-140.

200- Deitz FD, Sell JL, Bristol D. Rapid, Sensitive method for determination of mercury in a variety of biological samples. Journal of AOAC. $1973 \mathrm{abr} ; 56(2): 378-82$.

201- Câmara V de M, Campos RC, Perez MA, Tambelini AT, Klein CH. Teores de mercúrio no cabelo: um estudo comparativo em trabalhadores da lavoura de cana-de-açúcar com exposição pregressa aos fungicidas organo-mercuriais no município de Campos - RJ. Cad saúde pública. 1989 jan;2(3):359-72.

202- Ryabukkin YS. Activation analysis of hair as an indicator of contamination man by environmental trace element pollutants. Viena: International Atomic Energy Agency, Report IAEA/RI/50, 1978.

203- National Institute for safety and health (US). Manual of Analytical methods. $2^{\mathrm{a}}$ ed. USA: Niosh; 2003. p. 145-6. 
204- Mendes CR, Teixeira ATLS, Pereira RAT, Dias LCDS. Estudo comparativo de técnicas parasitológicas: kato-katz e coprotest ${ }^{\circledR}$. Rev soc bras med trop, 2005 jan;38(1):178-80.

205- Hoffman WA, Pons JA, Janer JL. The sedimentation concentration method in schistosomiasismansoni. J public health trop med. 1934 jan;9(1):283-91.

206- Katz N, Chaves A, Pellegrino JA. Simple device for quantitative stool thick-smear technique in Shistosomiasis mansoni. Rev inst med tropical. 1971 jan;14(6):397-400.

207- Environmental Protection Agency (EPA). National Waste Minimization Program. [internet] USA: EPA, 2011. [acesso 2013 novembro 10]. Disponível em: http://www.epa.gov/epaoswer/non-hw/reduce/catbook.htm

208- Associação Brasileira de Normas Técnicas (BR). NBR 10.007: amostragem de resíduos sólidos. Rio de Janeiro, 2004. 21p.

209- Monteiro JHP, Zveibil VZ. Manual de gerenciamento integrado de resíduos sólidos. Rio de Janeiro: IBAM, 2001.

210- Brasil. Ministério do Desenvolvimento Agrário. Plano de Trabalho: identificação, reconhecimento, delimitação, demarcação e titulação das terras ocupadas por remanescentes das comunidades de quilombos. Brasília: Instituto Nacional de Colonização e Reforma Agrária (INCRA), 2004.

211- Barreto JN. Implantação de infraestrutura habitacional em comunidades tradicionais: o caso da comunidade quilombola Kalunga. [dissertação de mestrado]. Brasília: Universidade de Brasília, 2009.

212- Instituto Brasileiro de Geografia e Estatística (IBGE). Coordenação de População e Indicadores Sociais. Síntese de Indicadores Sociais: uma análise das condições de vida da população brasileira. Rio de Janeiro: IBGE; 2013.

213- Instituto Brasileiro de Geografia e Estatística (IBGE), Censo Demográfico 2010, Características da População e dos Domicílios, Resultados Preliminares da Amostra, 2010. [internet]. Brasília: IBGE, 2010. [acesso 2013 novembro 25]. Disponível em: http://www.ibge.gov.br/home/estatistica/populacao/censo2010/resultados_preliminares_amost ra/default_resultados_preliminares_amostra.shtm 
214- Avelar G, Vicente de Paula M. Comunidade Kalunga: trabalho e cultura em terra de negro [internet]. GEOgraphia. 2009 nov 05 [acesso 2014 setembro 23];5(9):115-31. Disponível em: http://www.uff.br/geographia/ojs/index.php/geographia/article/view/118/115

215- Neiva ACGR. Sereno JRB, Santos AS, Fioravanti MCS. Caracterização socioeconômica e cultural da comunidade quilombola Kalunga de Cavalcante, Goiás, Brasil: dados preliminares. Paper presented at the IX Simpósio Nacional do Cerrado; 2008 out; Brasília, DF.

216- Nunes M de L, Nazareno E. Manifestações culturais em território Kalunga: a festa de Nossa Senhora de Aparecida como elemento de (re)afirmação identitária e reaproximação étnica. Multi journal educ research. 2012 jan; 2 (1):105-27.

217- Cruz KCMS, Valente ALEF. Produção familiar, agronegócio e desenvolvimento local sustentável em área remanescente de quilombo um estudo de caso na comunidade Kalunga. In: XLII Congresso da Sociedade Brasileira de Economia e Sociologia Rural, 2004; Campo Grande: SOBER. p. 487-8.

218- Magalhães NA, Koyanagi R. Photoessay: Kalunga's territory in Vão das Almas community in the satate of Goiás. Rev RDP. 2013 jan;1(1):198-201.

219- Koyanagi R, Nancy AM. Rancho Kalunga no Vão de Almas. Rev perspectivas desenv. 2013 mar;1(1):198-201.

220- Amorim MM, Tomazi L, Silva RAA, Gestinari R de S, Figueiredo TB. Avaliação das condições habitacionais e de saúde da comunidade quilombola Boqueirão, Bahia, Brasil. Bioscience journal. 2013 jul-ago;29(4):1049-50.

221- Kouri J, Fernandes AV, Lopes RP Filho, Sousa WP. Estrutura de renda dos produtores da reserva extrativista do Rio Cajari, Amapá. Boletim de pesquisa e desenvolvimento. Macapá: Embrapa Amapá; 2002.

222- Cabral-Miranda G, Dattoli VCC, Dias-Lima A. Enteroparasitos e condições socioeconômicas e sanitárias de uma comunidade quilombola do semi-árido Baiano. Rev patol trop. 2010 jan-mar;39(1):48-55. 
223- Santos LP, Santos FLN, Soares NM. Prevalência de parasitoses intestinais em pacientes atendidos no Hospital Universitário Professor Edgar Santos, Salvador- Bahia. Rev patol trop. 2007 abr;36(1):237-46.

224- Fioravanti MCS, Sereno JRB, Neiva ACGR, Abud LJ, Lobo JR, Francescantônio DD, Machado JDL. Reintrodução do gado curraleiro na comunidade quilombola Kalunga de Cavalcante, Goiás, Brasil: resultados parciais. In: IX Simpósio Nacional do Cerrado, II Simpósio Internacional de Savanas Tropicais; 2008 Oct 12-17; Brasília, DF: Paria Mundi; 2008.

225- Basso RMC, Silva-Ribeiro RT, Soligo DS, Ribacki SI, Callegari-Jacques SM, Zoppas BCDA. Evolução da prevalência de parasitoses intestinais em escolares em Caxias do Sul, RS. Rev soc brasileira med trop. 2008 ago; 41(3):263-8.

226- Reymão AE, Saber BA. Acesso à água tratada e insuficiência de renda. Duas dimensões do problema da pobreza no Nordeste brasileiro sob a óptica dos Objetivos de Desenvolvimento do Milênio. Revi Iberoamericana Econ Ecológica. 2009 mar;2(1):1-15.

227- Ministério da Saúde (Brasil). Portaria $n^{\circ}$. 518, de 25 de março de 2014. Estabelece os procedimentos e responsabilidades relativos ao controle e vigilância da qualidade da água para consumo e seu padrão de potabilidade e dá outras providências. Diário Oficial da União 25 mar 2004; Seção 1.

228- Cordeiro, MR, Rodrigues, AM, Souza, PRN, Ferreira, MIP. Avaliação da contaminação de efluentes domésticos em poços sobre área de restinga. Boletim do Observatório Ambiental Alberto Ribeiro Lamego. 2011;5(1):89-102.

229- Motta MEFA, Silva GAP. Diarréia por parasitas. Rev bras saúde mater infant. 2002 maiago; 2(2):117-27.

230- Komagome SH, Romagnoli MPM, Previdelli ITS, Falavigna DLM, Dias MLGG, Gomes ML. Fatores de risco para infecção parasitária intestinal em crianças e funcionários de creche. Cienc cuid saúde. 2007 fev;6(1):442-7.

231- Telarolli R Jr, Machado JCMS, Carvalho F. Perfil de saúde e condições demográficas dos idosos em uma comunidade em uma área urbana do Sudeste do Brasil. Rev saúde pública. 1996 out;30(5):485-98. 
232- Kightlinger LK, Seed JR, Kightlinger, MB. Ascaris lunbricoides intestity in relation enviromental, socioeconomic and behavioral determinants of esposure to infection in children from southeast Madagascar. J parasitol. 1998 fev;84(1):408-84.

233- Fernandes F da C, Barbosa FHF. Ocorrência de parasitoses intestinais entre crianças da creche Menino Jesus do município de Dores do Indaiá, Minas Gerais. Rev ciênc equatorial. 2011 jan-jun;1(1):28-37.

234- Gazola L. Avaliação da água de abastecimento ea prevalência das patologias de veiculação hídrica em uma comunidade do Morro do Quilombo-Florianópolis (SC), 2008. Rev elsevier. 2010 nov;30(6):380-7.

235- Takaynagui OM. Oliveira CD, Bergamini AMM, Capuano DM, Okino MHT, Febronio LHP, Silva AMC, Oliveira MA, Ribeiro EGA, Takaynagui AMM. Fiscalização de verduras comercializadas no município de Ribeirão Preto, SP. Rev soc brasileira med trop. 2001janfev;34(1):37-41.

236- Chehter L, Cabeça M, Catapani WR. Parasitoses intestinais. Rev bras med. 1995 mar; 51(1):126-32.

237- Agency for Toxic Substances and Disease Registry (ATSDR). Toxicological profile for mercury. Atlanta: U. S. Public Health Service, 1989.

238- Kitahara SE, Okada IA, Sakuma AM, Zenebon O, Jesus RS, Tenuta A Filho. Mercúrio total em pescado de água doce. Ciênc. tecnol aliment. 2000 abr;20(2):267-73.

239- Divisão Nacional de Vigilância Sanitária de Alimentos (DINAL). Agência Nacional de Vigilância Sanitária (Brasil). Portaria n. ${ }^{\circ} 685$ de 27 de agosto de 1998. Estabelece os princípios gerais para a determinação de níveis máximos de contaminantes químicos em alimentos. Diário Oficial da União 24 set. 1998; Seção 1.

240- Limaverde AM Filho, Campos RC. Redução seletiva aplicada à especiação do mercúrio em peixes: uma adaptação do método de Magos. Quím nova. 1999 out;22(4):477-82.

241- Reuther R. Mercury accumulation in sediments and fish from rivers affected by alluvial mining in the Madeira river basin, Brazil. Rev ambio. 1994 jan;19(1):11-5. 
242- Bastos WR, Lacerda LD. A contaminação por mercúrio na bacia do rio Madeira: uma breve revisão. J geochim. 2004 mai;18(2)99-114.

243- Environmental Protection Agency (EPA). The national survey of Mercury concentration in fish database survey 1990-1995. Ottawa: EPA, 1997.

244- Davidson PW, Myers GJ, Cox C. Effects of prenatal and postnatal methylmercury exposure from fish consumption on neurodevelopment: outcomes at months of age in the seychelles child development study. J american medical assoc. 1998 ago;280(8):701-7.

245- Kasper D, Botaro D, Palermo EFA, Malm O. Mercúrio em peixes-fontes e contaminação. Rev oecologia brasiliensis. 2007 mai;11(2):228-39.

246- Centro de Tecnologia Mineral (CETEM). Ciclo do Mercúrio no Meio Ambiente [internet]. Rio de Janeiro; 2007. [acesso em 2014 mai 13]. Disponível em: http://www.cetem.gov.brlmercuriolsemiquantlProb.html

247- Jesus RS. Inpa participa de evento internacional sobre qualidade e tecnologia do pescado [internet]. Agencia CT, Ministério da Ciência e Tecnologia. Brasília: 2007. [acesso em 2013 ago 10]. Disponível em: http://agenciact.mct.gov.br/index.php/content/view/42382.html

248- Dias AC, Guimarães JR, Malm O. Mercúrio total em músculo de cação Prionace glauca (Linnaeus, 1758) e de espadarte Xiphias gladius Linnaeus, 1758, na costa sul-sudeste do Brasil e suas implicações para a saúde pública. Cad saúde pública. 2008 set; 24(9):2063-70.

249- Mendez E, Giudice H, Pereira A, Inocente G, Medina D. Total Mercury content: fish weight relationship in swordfish (Xiphias gladius) caught in the southwest Atlantic Ocean. J food compost anal. 2001 jan;14(1):453-60.

250- Azevedo FA, Chasin AAM. As bases toxicológicas da ecotoxicologia. São Paulo: Rima; 2003.

251- Holsbeek L, Das HK; Joiris CR. Mercury in human hair and relation to fish consumption in Bangladesh. The science total environment. 1996 set;186(3):181-8.

252- Saiki M, Vasconcellos MBA, Arauz LJ, Fulfaro R. Mercury contamination in humans linked to river chemistry. Rev AMBIO. 1998 mar;28(1)519-21. 
253- World Health Organization (WHO). Methylmercury international programme on chemical safety. Genova, 1990.

254- Santos E Filho, Silva R S, Sakuma AM, Scorsafava MA. Teores de chumbo e mercúrio em cabelo de crianças residentes de Cubatão, região sudeste do Brasil. Rev saúde pública. 1993 mai;27(2):81-6.

255- Vilhena MPSP, Costa ML, Berrêdo JF, Sá GC, Costa AM, Santos EO, Brabo ES. Mercúrio em sedimentos de mangues, caranguejos (Ucidescordatus) e cabelos humanos em torno dos manguezais do nordeste do Pará. Rev geochim brasiliensis. 2003 jan;17(2):121-9.

256- Santos ECO, Câmara V de M, Brabo E da S, Loureiro ECB, Jesus IM, Fayal K, Sagica F. Avaliação dos níveis de exposição ao mercúrio entre índios Pakaanóva, Amazônia, Brasil. Cad saúde pública. 2003 jan;19(1):199-206.

257- Farias LA, Santos NR, Favaro DI, Braga ES. Mercúrio total em cabelo de crianças de uma população costeira, Cananéia, São Paulo, Brasil. Cad saúde pública. 2008 jan;24(10):2249-56.

258- Marques RC, Dórea JG, Bastos WR, Rebelo MF, Fonseca MF, Malm O. Maternal Mercury exposure and neuro-motor development in breastfed infants from Porto Velho, Brasil. Int j hyg environ health. 2007 fev; 210(1):51-60.

259- Meyer DEE. Educação em saúde na escola: transversalidade ou silenciamento? In: Meyer DEE, editores. Saúde e sexualidade na escola. $2^{\text {a }}$ ed. Porto Alegre: Mediação, 1998. p. 5-17.

260- Franco EAP, Barros RF. Uso e diversidade de plantas medicinais no quilombo Olho D’água dos Pires, Esperantina, Piauí. Rev brasileira plantas Med. 2006 set;8(3):78-88.

261- Freitas DB, Silva J de M, Galvão EFC. A relação do lazer com a saúde nas comunidades quilombolas de Santarém. Rev brasileira ciênc esporte. 2009 mai;30(2):89-105.

262- Vicente JP. Os remanescentes de quilombos do Vale do Ribeira no sudoeste de São Paulo: piora na situação socioeconômica e de saúde. Rev pediat. 2006 jan;26(1):63-5.

263- Monteles R, Pinheiro CUB. Plantas medicinais em um quilombo maranhense: uma perspectiva etnobotânica. Rev biologia ciênc terra. 2007 jun;7(2):38-48. 
264- Silva DO, Guerrero AFH, Guerrero CH, Toledo LM. A rede de causalidade de insegurança alimentar e nutricional de comunidades quilombolas com a construção da rodovia BR-163, Pará, Brasil. Rev de nutr. 2008 jan; 21(suplemento):83-97.

265- Brasil. Ministério da Saúde. Secretaria de Atenção à Saúde. Banco de Dados do Sistema Único de Saúde - DATASUS [internet]. Brasília: 2014. [acesso em 2012 ago 21]. Disponível em: $\underline{\text { www.datasus.gov.br }}$

266- Guerrero AFH, Oliveira D, de Toledo LM, Guerrero JCH, Teixeira P. Mortalidade infantil em remanescentes de quilombos do Munícipio de Santarém-Pará, Brasil. Saúde soc. 2007 abr;16(2):103-10.

267- Jardim PCBV, Carneiro O, Carneiro S, Baiocchi MN. Pressão arterial em comunidade negra isolada remanescente de quilombo - norte de Goiás - Kalunga. Arq bras cardiol. 1992 out;58(4):289-93.

268- Kochergin CN, Proietti FA, César CC. Comunidades quilombolas de Vitória da Conquista, Bahia, Brasil: autoavaliação de saúde e fatores associados Cad saúde pública. 2014 jul;30(7):1487-501.

269 - Leite IK. O projeto político quilombola: desafios, conquistas e impasses atuais. Est. Fem. 2008;16(3):965-77.

270- Marques AS, Caldeira AP, Souza LR, Zucchi P, Cardoso WDA. População quilombola no norte de Minas Gerais: invisibilidade, desigualdades e negação de acesso ao sistema público de saúde. Rev BIS. 2010 jun;12(2):155-61.

271- Freitas DA, Silveira JCS, Ferreira LA, Zucchi P, Marques AS. Mulheres quilombolas: profissionais na estratégia de saúde da família. Rev espaço saúde. 2011 jul;12(2):56-62.

272- Meireles V de B; Barros CAV, Barcellar HPH. Incidência de escabiose em alunos de uma escola pública de Belém - Pará. Rev para med. 2001 jul-set;15(4):47-50.

273- Lucena AR. Estudo epidemiológico do tracoma em comunidade da Chapada do AraripePernambuco - Brasil. Arq bras oftalmol. 2004 dez;67(1):197-200.

274- Oliveira F. Uma contribuição ao debate sobre raça/etnia e saúde. Rev sexualidade, gênero soc [edição especial]. $2001 \mathrm{dez} ; 15(16): 54-63$. 
275- Minayo MC de S. Condiciones de vida, diversos sentidos da fome em quilombos da região desigualdad y salud a partir del caso brasileño. In: Briceño R, Minayo MC de S, Coimbra C, editores. Salud y equidad: uma mirada desde lascienciassociales. Rio de Janeiro: Fiocruz, 2000. p. 55-72.

276- Coimbra CEA Jr, Santos RV. Saúde, minorias e desigualdade: algumas teias de interrelações com ênfase nos povos indígenas no Brasil. Ciênc saúde colet. 2000 fev;5(1):125-32.

277- Orrico SEM. Sistema associativo de saneamento e seus efeitos sobre a população em comunidades do semiárido baiano [tese de doutorado]. São Paulo (SP): Faculdade de Saúde Pública da Universidade de São Paulo; 2003.

278- Freitas CM. Problemas ambientais, saúde coletiva e ciências sociais. Ciênc saúde colet. 2003 jan;8(1):137-50. 


\section{APÊNDICES}




\title{
APÊNDICES
}

\section{APÊNDICE A - TERMO DE CONSENTIMENTO LIVRE E ESCLARECIDO - TCLE}

\author{
1a Via - Via do Pesquisador
}

Prezado(a) senhor (a), você está sendo convidado (a) para participar da pesquisa intitulada "Avaliação das Condições Sanitárias da População Kalunga no Estado de Goiás no Ano de 2012 - Municípios de Cavalcante, Teresina de Goiás e Monte Alegre". Sua participação é voluntária e você poderá a qualquer tempo desistir de participar sem nenhum prejuízo a sua pessoa. Esta pesquisa está vinculada ao Programa de Pós-Graduação em Enfermagem da Universidade de Brasília - Modalidade Doutorado, sob orientação do Prof. Dr. Pedro Sadi Monteiro. O objetivo da realização da pesquisa é avaliar as condições sanitárias da população Kalunga dos municípios de Cavalcante, Teresina de Goiás e Monte Alegre, Estado de Goiás, no ano de 2012.

A sua contribuição para a realização deste estudo é muito valiosa e não impacta em custo ou vantagem financeira, consistindo na disponibilidade em responder algumas perguntas por meio de uma entrevista, que será respondida coletivamente em uma oficina de trabalho com hora e local agendados previamente ou respondida individualmente por ocasião de visita domiciliar. As entrevistas terão seu áudio gravado, contudo serão garantidos o sigilo e o anonimato das informações. Os comentários acerca das perguntas da entrevista, depois de gravados em meio digital, serão transcritos integralmente, bem como os dados serão registrados em formulário específico pelo próprio pesquisador, visando-se, exclusivamente, à geração de informação. Transcorridos cinco anos, tanto as gravações quanto os formulários serão destruídos. Os resultados da pesquisa serão divulgados na Universidade de Brasília, podendo ser publicados posteriormente em periódicos nacionais ou internacionais. pesquisa:

É importante ressaltar ainda outros aspectos assegurados aos participantes desta

A garantia do respeito ao anonimato e a confidencialidade das respostas, não sendo, em nenhum momento, divulgado o seu nome;

A garantia da participação voluntária, podendo desistir da pesquisa a qualquer momento, sem com isto possa gerar prejuízo em decorrência de sua participação;

Serão respeitados os valores culturais, sociais, morais, religiosos e éticos, bem como os hábitos e costumes dos participantes;

Este documento foi elaborado em duas vias e você receberá uma cópia deste termo, onde consta o telefone e e-mail do pesquisador, podendo tirar suas dúvidas sobre o projeto e sua participação, a qualquer momento.

Este projeto foi Aprovado pelo Comitê de Ética em Pesquisa da Faculdade de Ciências da Saúde da Universidade de Brasília (CEP - FS UnB). As dúvidas com relação à assinatura do TCLE ou os direitos do sujeito da pesquisa podem ser obtidos pelo do telefone: (61) 3107 1947. 
Certos de contar com a sua colaboração.

Atenciosamente,

\section{Doutoranda Débora Luiza de Oliveira Rangel}

Doutorado PPGEnf - UnB - Telefone: (61) 3312-3374 / Celular: (61) 96727327

E-mail: deborarangel@ymail.com.br

Declaro estar ciente do inteiro teor deste TERMO DE CONSENTIMENTO e estou de acordo em participar do estudo proposto.

Nome:

Identidade:

Assinatura

Brasília, de de 2012. 


\section{APÊNDICE B - INSTRUMENTO DE COLETA DE DADOS 01}

Roteiro Para Entrevista Semiestruturada:

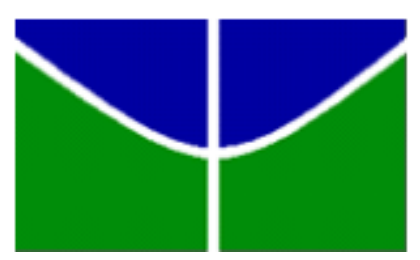

Universidade de Brasília

Faculdade de Ciências da Saúde

Departamento de Enfermagem

Programa de Pós-Graduação em Enfermagem

\section{MUNICÍPIO:}

(1) Cavalcante

(2) Monte Alegre

(3) Teresina de Goiás

\section{LOCAL DO QUILOMBO/POVOADO}

(1) Número $(\ldots \ldots$ _ $)$ :

3. IDENTIFICAÇÃO

(1) Líder comunitário $\quad$ (2) Membro da comunidade

3.1 Iniciais:

4. SEXO:

$\begin{array}{ll}\text { (1) Masculino } & \text { (2) Feminino }\end{array}$

I - Identificação de Problemas Gerais:

1) Qual é o maior problema que as Comunidades Kalungas enfrentam?

2) Na sua opinião, qual é a melhor solução para isto?

3) Quem é o principal responsável pela adoção destas medidas resolutivas?

II - Identificação dos Problemas de Saúde:

4) O que é saúde você? E para a sua comunidade? O que é ter uma comunidade com saúde?

5) Na sua opinião, a comunidade enfrenta alguma dificuldade para buscar ou melhorar suas condições de saúde?

6) Quais são os principais problemas de saúde que as Comunidades Kalungas enfrentam?

7) Como estes problemas podem ser resolvidos? O que deve ser feito para isto? 
8) Quem é o principal responsável em adotar as medidas apropriadas para resolver estas questões?

III - Identificação de problemas relacionados ao acesso a terra:

9) Os Kalungas enfrentam quais problemas relacionados à terra?

10) Estes problemas podem afetar a saúde da comunidade?

11) O que deve ser feito para a resolução destes problemas?

12) Quem deve ser o principal responsável em resolver esta questão da terra?

IV - Identificação de problemas relacionados com a educação:

13) Como é a Educação em sua comunidade? Existem problemas?

14) Existem escolas em sua comunidade? Como elas são?

15) Estes problemas podem afetar a saúde da comunidade?

16) O que poderia ser feito para resolver?

17) Frente a estas questões, quem é o responsável por resolver estes problemas?

V - Identificação de problemas relacionados com o transporte:

18) Como os moradores se deslocam para o acesso à escola e aos serviços de saúde?

19) Existem problemas com este transporte?

20) Estes problemas podem afetar a saúde da comunidade?

21) O que pode ser feito para resolver estes problemas?

22) Quem são os responsáveis pela resolução destas questões? 


\section{APÊNDICE C - INSTRUMENTO DE COLETA DE DADOS 02}

Roteiro Para Observação Direta:

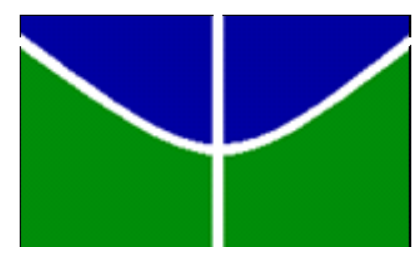

Universidade de Brasília

Faculdade de Ciências da Saúde

Departamento de Enfermagem

Programa de Pós-Graduação em Enfermagem

\section{ANOTAÇÕES DE CAMPO}

Parte I - Observações da Oficina de Trabalho:

Comunidade

N. ${ }^{\circ}$ participantes:

a) Problemas de saúde mencionados:

b)Áreas referenciadas segundo os problemas de saúde: 
c) Observações Gerais:

Assinatura do Observador:

Data:

/2012

Parte II - Observações das Visitas Domiciliares:

Município:

Residência Visitada/Morador:

Número de Moradores:

Data:_______ Hora:

Observador:

a) Aspectos Geográficos e Sociais do Quilombo:

b) Condições Higiênico Sanitárias do Peridomicílio:

c) Fatores relacionados à origem, produção e destinação dos resíduos sólidos:

d) Observações Gerais:

Assinatura do Observador:

Data:

$/ 2012$ 


\section{APÊNDICE D - INSTRUMENTO DE COLETA DE DADOS 03}

Formulário Para Caracterização Da Amostra:

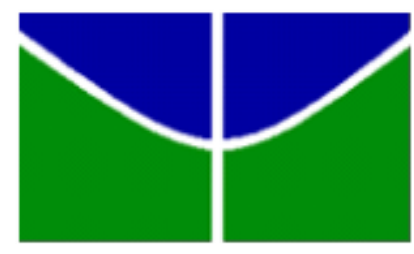

Universidade de Brasília

Faculdade de Ciências da Saúde

Departamento de Enfermagem

Programa de Pós-Graduação em Enfermagem

\section{A- IDENTIFICAÇÃO DO PARTICIPANTE}

\section{MUNICÍPIO:}
(1) Cavalcante
(2) Monte Alegre
(3) Teresina de Goiás

\section{LOCAL DO QUILOMBO/POVOADO}

(1) Número $\left(=\frac{}{2}\right)$ :

\section{IDENTIFICAÇÃO}
(1) Líder comunitário
(2) Membro da comunidade

\subsection{Iniciais:}

\section{SEXO:}

\section{(1) masculino (2) feminino}

5.IDADE:
(1) entre 18- 20 anos
(2) entre 21-30 anos
(3) entre 31-40 anos
(4) entre 41-50 anos
(5) entre 51-60 anos
(6) entre 61- 70 anos
(7) entre 71-80 anos
(8) acima de 81 anos

6. ESTADO CIVIL
(1) Solteiro
(2) Casado
(3) Viúvo
(4) Divorciado
(5) Outro

7. ESCOLARIDADE:

(1) Não alfabetizado

(2) Ensino Fundamental Incompleto

(3) Ensino Fundamental Completo

(4) Ensino Médio Incompleto

(5) Ensino Médio Completo

(6) Ensino Superior Completo

(7) Ensino Superior Completo

(8) Outro

7.1 Especificar até que série/período:

8. OCUPAÇÃO:

(1) Especificar:

8.1 Emprego Atual:
(1) Formal
(2) Informal
(1) No povoado
(2) Fora do povoado
(3) Onde?

9. QUANTIDADE DE MORADORES NO DOMICÍLIO
(1) Um
(2) Dois
(3) Três
(4) Quatro
(5) Cinco
(6) Seis ou mais 
10. NÚMERO DE FILHOS
(1) 0 filho
(2) entre 1-2 filhos
(3) entre 3-4 filhos
(4) entre 5-6 filhos

\begin{tabular}{lll}
\hline (5) entre 6-7 filhos (6) entre 8-9 filhos & (7) acima de 10 filhos
\end{tabular}

10.1 Tem histórico na família de crianças nascidas mortas?
(1) Sim
(2) Não

10.2 Alguma criança morreu logo depois que nasceu?
(1) $\mathrm{Sim}$
(2) Não
11. RENDA MENSAL (em salários mínimos)

(1) menos de 1 salário mínimo

(2) De 1 até menos de 2 salários mínimos

(3) De 2 até menos de 3 salários mínimos

(4) De 3 até menos de 4 salários mínimos

(5) De 4 até menos de 5 salários mínimos

(6) De 5 até menos de 6 salários mínimos

(7) De 6 até menos de 7 salários mínimos

(8) De 7 até menos de 8 salários mínimos

(9) Mais que oito salários mínimos
11.1 Recebe Bolsa do Governo?
(1) $\mathrm{Sim}$
(2) Não
Se sim, qual?
12. TABAGISTA
(1) Sim
(2) Não

13. ETILISTA
(1) $\mathrm{Sim}$
(2) Não

14. DIABÉTICO
(1) $\mathrm{Sim}$
(2) Não Se sim: (1) Tipo I
(2) Tipo II

15. HIPERTENSO
(1) $\mathrm{Sim}$
(2) Não

15.1 Pressão Arterial: $\mathrm{X}$ $\mathrm{mmHg}$
15.2 Já aferiu a PA anteriormente?
(1) $\mathrm{Sim}$
(2) Não

\section{B- IDENTIFICAÇÃO DO DOMICÍLIO}

\section{TIPO DE CASA}
(1) Adobe
(2) Madeira
(3) Alvenaria sem Reboco
(4) Alvenaria com Reboco
(5) Outro - Especifique:
17. PISO INTERNO DA CASA
(1) Terra Batida
(2) Cimento
(3) Cerâmica
(4) Madeira
(5) Outro:
18. TELHADO DA CASA
(1) Palha
(2) Telha de Barro
(3) Telha Metálica
(4) Laje
(5) Outro:
19. NÚMEROS DE CÔMODOS
(1) Somente 1 cômodo
(2) entre 2-3 cômodos
(3) entre 4-5 cômodos
(4) acima de 6 cômodos

20. TIPO DE ILUMINAÇÃO DO DOMICÍLIO
(1) Lampião a Querosene (velas)
(2) Lampião a Gás
(3) Rede Elétrica (4) Outro:
21. PROVENIÊNCIA DA ÁGUA

(1) Rede Pública de Abastecimento

(2) Poço

(3) Rios

(4) Outro:

22. PROVENIÊNCIA DA ÁGUA DE BEBER
(1) Rede Pública de Abastecimento
(2) Poço
(3) Rios
(4) Outro:

23. REALIZA ALGUM TRATAMENTO COM A ÁGUA
(1) Sim
(2) Não
23.1 Se sim, qual? (1) Ferve
(2) Decanta
(3) Clora 
(4) Filtra (5) Outro:

24. ÁGUA ENCANADA DENTRO DA CASA

(1) $\mathrm{Sim}$ (2) Não

25. REDE DE ESGOTO

(1) Sim (2) Não

26. DESTINO DADO AOS DEJETOS HUMANOS

(1) Céu Aberto (2) Enterrado (3) Fossa Séptica (4) Fossa Negra (5) Outro:

27. INSTALAÇÃO SANITÁRIA - Casa tem Banheiro

(1) Sim (2) Não

28. LAVA AS MÃOS SEMPRE APÓS UTILIZAR O BANHEIIRO OU EQUIVALENTE?

(1) $\operatorname{Sim}$ (2) Não

29. Presença de animais no domicílio?
(1) Sim
(2) Não

Quais? (1) Porco (2) Galinha

(3) Cavalo/Mulas

(4) Cachorro

(5) Gato

(6) Outros

30. DESTINAÇÃO DO LIXO

(1) Queima (2) Enterra (3) Joga a Céu Aberto (4) Utiliza Como Adubo (5) Outro:

31. EXISTE ALGUMA SEPARAÇÃO DE TIPO DE LIXOS?
(1) Sim
(2) Não

Especificar: (1) Restos de Comida

(5) Papéis

(6) Embalagens

(2) Roupas Velhas

(3) Plásticos

(4) Vidro

32. O LIXO PODE CAUSAR ALGUM TIPO DE PROBLEMA?
(1) $\mathrm{Sim}$
(2) Não

Se sim, (1) Doenças - Especificar:
(3) Quintal Sujo
(4) Mosquito
(5) Mosca
(6) Ratos

(2) Mau Cheiro

33. ACHA POSSÍVEL DIMINUIR A QUANTIDADE DE LIXO?
(1) Sim
(2) Não

(a) Sim, porque é importante para a saúde;

(b) Sim, para evitar o desperdício de coisas;

(c) Sim, para não sujar o quintal;

(d) Não, porque o lixo já é muito pouco;

(e) Não, porque o que dá já se aproveitou;

(f) Não sabe responder

(g) Outros

34. VACINAÇÃO
(1) $\mathrm{Sim}$
(2) Não

\section{C- IDENTIFICAÇÃO DA COMUNIDADE - Acesso a bens sociais e serviços}

\section{TERRA}

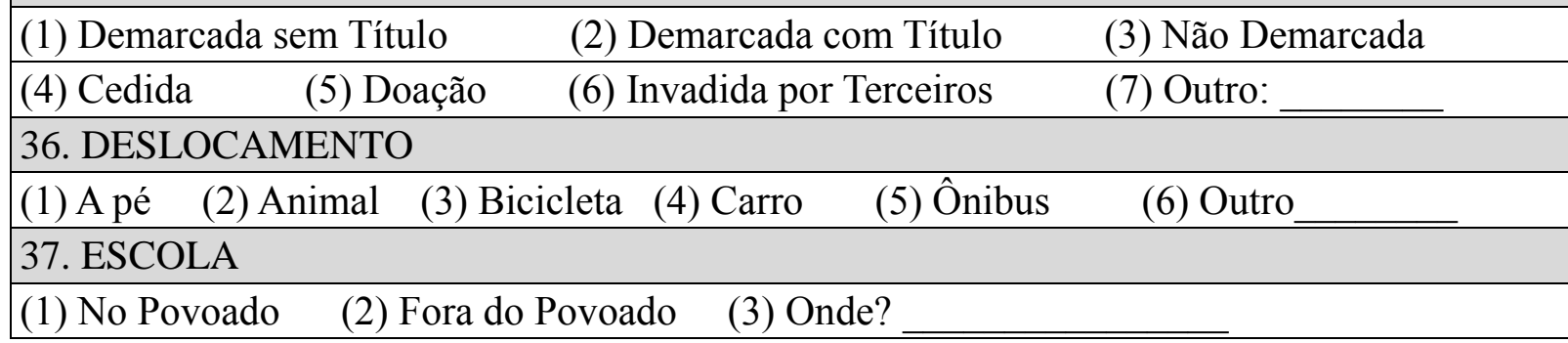




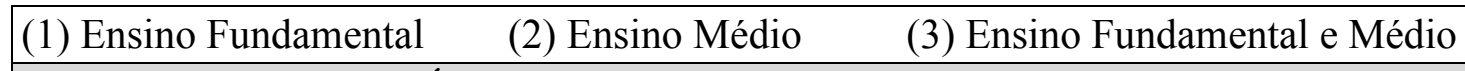
38. SERVIÇOS DE SAÚDE
(1) No povoado
(2) Fora do povoado
(3) Onde?

37.1 Qual a distância do serviço prestado?

39. TIPO DE SERVIÇO DE SAÚDE
(1) ESF
(2) Posto de Saúde
(3) Centro de Saúde
(4) Hospital
(5) Outro

40. PROFISSIONAL QUE COSTUMA ATENDER AS DEMANDAS EM SAÚDE
(1) Agente de Saúde
(2) Auxiliar ou Técnico de Enfermagem
(3) Enfermeiro
(4) Médico
(5) Outro

\section{PRINCIPAIS PROBLEMAS DE SAÚDE}

41.1 Diarreia:

a) Qual a última vez que alguém na casa teve diarreia?
(1) Menos de uma Semana
(2) Uma Semana
(3) Mais ou menos 15 dias

(4) Um Mês

(5) Outro:

b) Quem na casa teve diarreia?
(1) Criança
(2) Adolescente
(3) Adulto
(4) Idoso
Idade:

c) Você associa a diarreia a algum evento?
(1) $\mathrm{Sim}$
(2) Não

O que?

d) O que foi feito para resolver?

41.2 Sarna:

a) Tem alguém na casa com coceira na pele?
(1) Sim
(2) Não

b) Qual a última vez que alguém na casa teve coceira na pele?
(1) Menos de uma Semana
(2) Uma Semana
(3) Mais ou menos 15 dias
(4) Um Mês

(5) Outro:

b) Quem na casa teve coceira na pele?
(1) Criança
(2) Adolescente
(3) Adulto
(4) Idoso
Idade:

c) Você associa a coceira a algum evento?
(1) $\mathrm{Sim}$
(2) Não Qual?

d) O que foi feito para resolver?

41.3 Tracoma:

a) Tem alguém na casa com problema de coceira no olho?
(1) Sim
(2) Não

b) Qual a última vez que alguém na casa teve coceira no olho?
(1) Menos de uma Semana
(2) Uma Semana
(3) Mais ou menos 15 dias

(4) Um Mês

(5) Outro:

b) Quem na casa teve coceira no olho?
(1) Criança
(2) Adolescente
(3) Adulto
(4) Idoso
Idade:

c) Você associa esta coceira a algum evento? (1) Sim

(2) Não Qual?

d) O que foi feito para resolver? 
a) Nas refeições de ontem que tipo de alimento predominou?
(1) Cultivado
(2) Industrializado
b. Descrição dos Alimentos:
1.
2.
3.
4.
5.
c) Consome peixe na alimentação?
(1) $\mathrm{Sim}$
(2) Não

Se sim, qual a frequência?
(a) Diariamente
(b) Quatro vezes ou mais na semana
(c) Duas ou três vezes na semana
(d) Uma vez por semana
(e) A cada 15 dias
(f) Uma vez por mês
(g) Raramente
(e) Nunca

Se sim, qual a procedência deste peixe?
(a) Rios de Cavalcante
(b) Rios de Teresina
(c) Rios de Monte Alegre
(d) Outros
43. ECONOMIA
(1) Agricultura
(2) Pecuária
(3) Agricultura e pecuária
(4) Artesanato
(5) Turismo
(6) Culinária
(7) Ações governamentais - Qual(is)
(8) Outro
44. BENS DURÁVEIS

\begin{tabular}{|c|c|c|}
\hline (1)Automóvel (2)Motocicleta & (3) Geladeira & (5) Computador \\
\hline (7) Televisão & (8) Forno Microondas & (9) Antena Parabólica \\
\hline
\end{tabular}

(10) Outro:

D- TRADIÇÃO ÉTNICA E CULTURAL

45. DIALETO
(1) Sim
(2) Não Qual?
46. RELIGIÃO
(1) Sim
(2) Não Qual?
47. DANÇA

47.1 Existe algum grupo de dança ou folclórico na comunidade?
(1) $\mathrm{Sim}$
(2) Não Qual?

47.2 O Sr. (a) participa?
(1) $\mathrm{Sim}$
(2) Não
Qual? 
47.3 Existe interesse por parte dos jovens em preservar as tradições da comunidade?
(1) $\mathrm{Sim}$
(2) Não Por quê?

48. CULINÁRIA TÍPICA
(1) $\mathrm{Sim}$
(2) Não Qual?

49. ARTESANATO

(1) Sim (2) Não Qual?

49.1 Por que acha importante a preservação dos costumes, tradições e hábitos da comunidade?

\section{MEIOS DE COMUNICAÇÃO}

( ) Não escutam rádio, não leem revistas/jornais e nem assistem a televisão

( ) Escutam rádio, mas não tem acesso a televisão e/ou jornais e revistas

( ) Escutam rádio, assistem a televisão, mas não tem acesso jornais ou revistas

( ) Escutam rádio, assistem a televisão e tem acesso as informações de jornais e revistas, mas não tem acesso a informações da internet

( )Escutam rádio, assistem a televisão e tem acesso as informações de jornais, revistas e internet.

51. ESPAÇO COMUNITÁRIO
(1) Sim
(2) Não Qual?
52. LAZER
(1) $\mathrm{Sim}$
(2) Não Qual? 


\section{APÊNDICE E - INSTRUMENTO DE COLETA DE DADOS 04}

Formulário para Caracterização dos Resíduos Sólidos
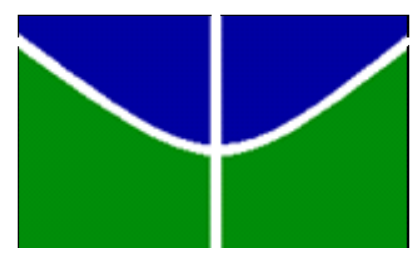

Universidade de Brasília

Faculdade de Ciências da Saúde

Departamento de Enfermagem

Programa de Pós-Graduação em Enfermagem

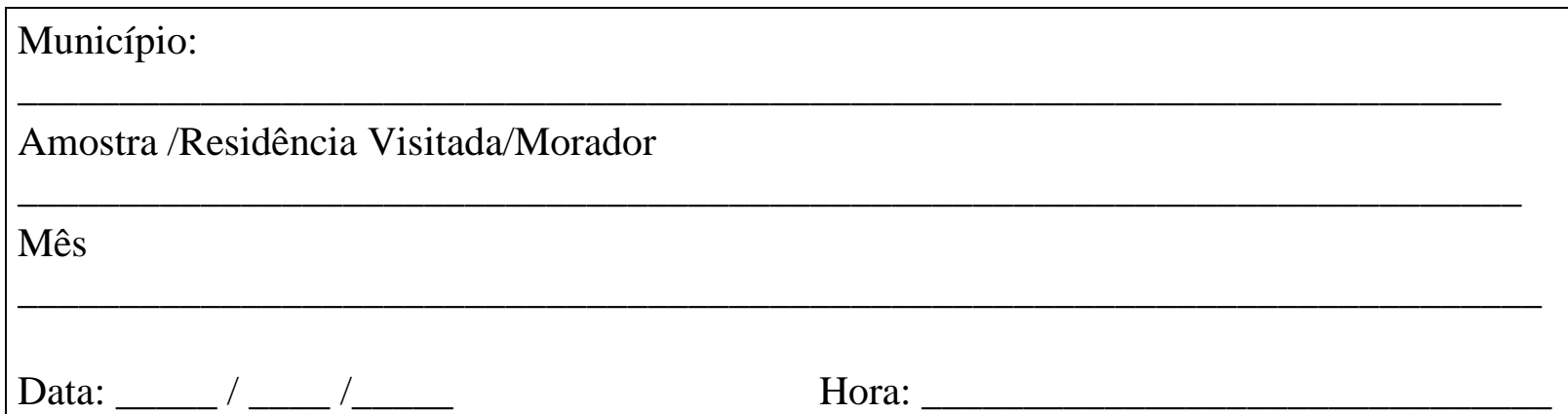

\begin{tabular}{|l|l|}
\hline Subtipo de Resíduo Sólido & \\
\hline 1. Matéria Orgânica: & Porcentagem \\
\hline 2. Papel / Papelão: & \\
\hline 3. Metal: & \\
\hline 4. Plástico: & \\
\hline 5. Vidro: & \\
\hline 6. Têxteis: & \\
\hline 8. Outros: & \\
\hline & \\
\hline
\end{tabular}


ANEXOS 


\title{
ANEXOS
}

\section{ANEXO A - Parecer favorável emitido pelo Comitê de Ética em Pesquisa com Seres Humanos da Faculdade de Ciências da Saúde da Universidade de Brasília}

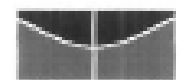 \\ Universidade de Brasilia \\ Faculdade de Ciências da Saúde \\ Comitê de Ética em Pesquisa-CEP/FS
}

\section{PROCESSO DE ANÁLISE DE PROJETO DE PESOUISA}

\author{
Registro do Projeto no CEP: 070/12 \\ Título do Projecto: "Avaliação das condiçōes Sanitárias da população Kalunga no estado \\ de Goiás no ano de 2012". \\ Pesquisadora Responsável: Débora Luiza de Oliveira Rangel \\ Data de Fnirada: 16/05/12
}

Com base na Resolução 196/96, do CNS/MS, que regulamenta a ktica em pesquisa com seres humanos, o Comitê de Ética em Pesquisa com Seres Humanos da Faculdade de Ciéncias da Saúde da Universidade de Brasilia, após análise dos aspectos éticos e do contexto técnico-científico, resolveu APROVAR o projeto 070/12 com o titulo: "Avaliação das condiçōes Sanitárias da população Kalunga no estado de Goiás no ano de 2012". analisado na $5^{*}$ Reunião Ordinária, realizada no dia 12 de junho de 2012 .

A pesquisadora responsível fiea, desde já, notificada da obrigatoriedade da apresentaçấo de um relatório semestral e relatório final sucinto e objetivo sobre o desenvolvimento do Projeto, no prazo de 1 (um) ano a contar da presente data (item VI1.13 da Resoluçĩo 196/96).

Brasilia. 20 de agosto de 2012. 


\title{
ANEXO B - Documento de Autorização do Presidente da Associação Quilombo Kalunga para a Realização da Pesquisa
}

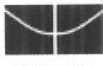 \\ UnB \\ UNIVERSIDADE DE BRASÍLIA \\ FACULDADE DE CIÊNCIAS DA SAÚDE \\ COMITÊ DE ÉTICA EM PESQUISA COM SERES HUMANOS \\ CAMPUS UNIVERSITARIO DARCY RIBEIRO \\ BRASÍLIA - DF \\ TELEFONE (061) 3107-1947 \\ E-mail: cepfs@unb.br \\ http:l/fs unb.br/cep/
}

\section{TERMO DE CONCORDÂNCIA}

A população Kalunga dos municípios de Cavalcante, Teresina de Goiás e Monte Alegre, por meio de seu líder comunitário, Presidente da Associação Quilombo Kalunga, senhor Sirilo dos Santos Rosa, está de acordo com a realização junto a esta comunidade da pesquisa "Avaliação das Condições Sanitárias da População Kalunga no Estado de Goiás no Avo de 2012 - Municípios de Cavalcante, Teresina e Monte Alegre".

Tal estudo se desenvolverá sob orientação do Professor Doutor Pedro Sadi, Monteiro tendo como aluna pesquisadora Débora Luiza de Oliveira Rangel - Identidade: 10.368.198-7, regularmente matriculada (Registro 10/0133355) no Curso de Doutorado pelo Programa de Pós Graduação em Enfermagem do Departamento de Enfermagem da Faculdade de Ciências da Saúde da Universidade de Brasília, após aprovação pelo Comitê de Ética em Pesquisa da Faculdade de Ciências da Saúde da Universidade de Brasília. O estudo envolve a realização de entrevistas, de oficinas e de exames laboratoriais em amostras da água para consumo, músculo de peixes, cabelo e fezes dos moradores da comunidade Kalunga.

Ressalta-se, por fim, que esta pesquisa tem a duração total de aproximadamente dois anos e seis meses, sendo que a etapa de coleta de dados, junto a esta população tem previsão de conclusão em um período de seis a doze meses a contar de julho de 2012 .

Cavalcante,
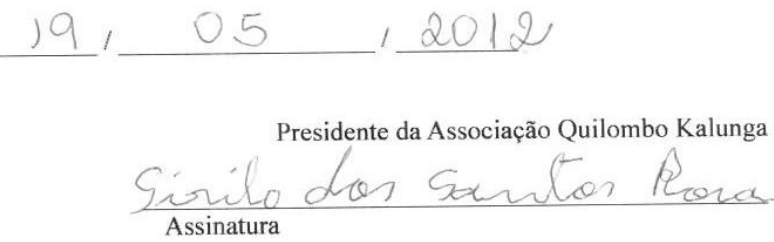

Aluna-Pesquisada Responsável pelo protocolo de pesquisa

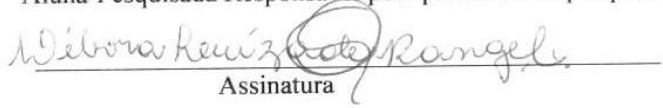

Professor Doutor Pesquisador Responsável pelo protocolo de pesquisa:

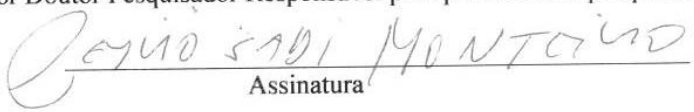




\section{ANEXO C - Decisão do Corpo Editorial da Revista Acta Paulista de Enfermagem da UNIFESP com relação à publicação do artigo "Perfil parasitológico de uma comunidade quilombola"}

\section{Prezados Autores,}

Tenho a grata satisfação de comunicar que a versão em anexo do seu artigo, foi aceita para publicação na Acta Paulista de Enfermagem. Parabéns!

A Acta é um periódico digital, open access e a versão final do seu artigo (em anexo) deverá ser traduzida para a língua inglesa. Não será possível nenhuma alteração adicional no artigo, por isso encaminhe a versão em anexo para o tradutor escolhido. Em http://www.unifesp.br/acta/tradutores.php você encontrará a lista de tradutores recomendados pela Acta. A versão final em inglês e a certificação emitida pelo tradutor, sem a qual não poderemos publicar o artigo, deverão ser enviadas para o e-mail ape@unifesp.br até às 14h00 do dia 01.09.2014.

Para o pagamento da taxa de edição acesse o link: http://www.unifesp.br/acta/taxa sub.php. Após efetuar o pagamento, envie o comprovante no email ape@unifesp.br.

Enfatizamos que os leitores poderão acessar o seu artigo nos dispositivos móveis em qualquer parte do mundo.

Atenciosamente,

Sonia Maria Oliveira de Barros

Editor-Chefe 


\title{
ANEXO D - Cópia do Artigo "Perfil parasitológico de uma comunidade quilombola"
}

\author{
Rangel DL, Oliveira C, Kyaw CM, Caldeira Júnior AM, Monteiro PS
}

APE-2014-0028

Parasitological profile of residents of a maroon community

\author{
Débora Luiza de Oliveira Rangel ${ }^{1}$ \\ Cesar de Oliveira ${ }^{2}$ \\ Cynthia Maria Kyaw ${ }^{1}$ \\ Antônio Marmoro Caldeira Júnior ${ }^{3}$ \\ Pedro Sadi Monteiro ${ }^{1}$
}

\section{Submitted}

February $18^{\text {th }}, 2014$

\section{Accepted}

August $20^{\text {th }}, 2014$

${ }^{1}$ Universidade de Brasília, Brasília, DF, Brazil.

${ }^{2}$ University College London, London, United Kingdom.

${ }^{3}$ Faculdade Sena Aires, Valparaíso de Goiás, GO, Brazil.

Conflicts of interest: no conflicts of interest to declare.

\section{Corresponding author}

Débora Luíza de Oliveira Rangel

Campus Universitário Darcy Ribeiro, Brasília, DF, Brazil. CEP: 70910-900

deborarangel@ymail.com

\section{Abstract}

Objective: Analyzing data on prevalence and species of intestinal parasites among residents of a maroon community. 
Methods: A non-probabilistic sample survey for accessibility or convenience was used. The sample consisted of 153 individuals who answered an epidemiological investigation form and underwent parasitological examination of feces by sedimentation technique of Hoffman-PonsJaner and analysis of water, according to the multiple tube technique to estimate medium density of microorganisms. The selection of the sample collection sites took into consideration the environmental and sanitary criteria.

Results: The proportion of infested individuals was $16.8 \%$ and the statistically significant variables were the municipality of residence $(p=0.048)$ and hygiene habits of hand washing $(p \leq 0.001)$. Variables such as piped water, presence of thermotolerant coliforms in the water $(p=$ $0.038)$ and treatment of drinking water $(\mathrm{p} \leq 0.001)$ were statistically associated with the variable of diarrheal episode in the last month $(\mathrm{p}=0.008)$.

Conclusion: The results indicated infestations by different species of parasites related to diarrheal episodes associated with poor hygiene conditions, especially the lack of drinking water treatment.

\section{Introduction}

This study is based on the concept of health in its social determinants interface. The health of populations is defined as a result of the forms of social organization and production, which can generate large inequalities in living standards. This complex network of factors is interrelated and affects the health-disease process in the individual specificity and scope of the collective way of life. ${ }^{(1)}$

Intestinal parasitosis is a public health problem and considered a disease closely related to socio-sanitary conditions. ${ }^{(2,3)}$ In data from the Brazilian Federal Government, the Kalunga territory is described as possessor of the lowest human development index in the state of Goiás, with notable problems related to housing, low educational level, frailty and even the total absence of basic sanitation and/or distribution of drinking water. ${ }^{(4)}$

The scenario of social vulnerability justifies studies in the area of health and its social determinants, as well as the fact that in Brazil there are insufficient references on the topic of incidence of parasitism in the population, despite its relevance in the epidemiology and public health. ${ }^{(5)}$ Therefore, the question of parasitic infestations demands attention when it comes to specific minority groups.

This study aimed to analyze data on the prevalence of intestinal parasites among Kalunga residents, describing the species of greater prevalence and medical-social interest. 


\section{Methods}

The study was carried out in the state of Goiás, in the municipalities of Cavalcante, Teresina de Goiás and Monte Alegre, in the west-central region of Brazil. Historically and numerically, Kalunga is considered the most important remaining maroon community of the region, with about 5,000 inhabitants. ${ }^{(6)}$

The cross-sectional design, with non-probabilistic sample survey was chosen in the composition of the sample. Socioeconomic information and other data regarding the source of drinking water, sanitation and hygiene habits were collected. Stool examination was performed by the sedimentation technique of Hoffman-Pons-Janer and analysis of water, according to multiple tube technique to estimate the average density of microorganisms. The selection of the sample collection sites took into consideration environmental and health criteria.

Statistical analyzes were performed with the IBM Statistical Package for the Social Sciences application version 21, in partnership with the University College London. The chi-square test at a significance level of $5.0 \%$ and a confidence interval of $95 \%$ were adopted.

The development of the study met national and international standards of ethics in research involving human beings.

\section{Results}

The investigation form was answered by 67 families and 153 individuals (Table 1). It was observed that only two $(1.3 \%)$ residents had permanent formal employment, while the remaining $151(98.7 \%)$ survived with informal activities. The illiteracy rate was 51.0\% ( $\mathrm{n}=78)$ and the monthly family income lower than minimum wage $(n=91,59.5 \%)$ prevailed. In homes, the adobe was the most common material used for construction ( $\mathrm{n}=79,51.6 \%$ ), and burnt cement $(\mathrm{n}=89,58.2 \%)$ or $\operatorname{dirt}(\mathrm{n}=64 ; 41.8 \%)$ were used for indoor flooring. The earthen floor comprised 100 per cent of peridomesticspace. The diet was based on subsistence cultivation of local $(\mathrm{n}=91,59.5 \%)$ crops. All residents were using water from rivers in the region, whether through capture by hoses ( $\mathrm{n}=87,56.9 \%$ ), wells $(\mathrm{n}=38,24.4 \%)$ or river water search with gallons $(\mathrm{n}=28,18.3 \%)$. Almost half of the residents $(\mathrm{n}=76,49.7 \%)$ did not carry out any treatment in the drinking water. Some level of thermotolerant coliforms was detected in $42.5 \%$ ( $\mathrm{n}$ =65) samples.

Table 1.Sanitary socioeconomic characteristics observed in Kalunga community

\begin{tabular}{lcc}
\hline Variables & Yes (\%) & No (\%) \\
\hline Formal employment & $2(1.3)$ & $151(98.7)$ \\
Education level (literacy) & $75(49.0)$ & $78(51.0)$
\end{tabular}


Monthly income (lower than minimum wage)

Type of material used for construction of the house (adobe)

Type of indoor flooring (burnt cement)

Peridomicile (earthen floor)

Provenience of the water (river)

Piped water inside the house

Treatment with drinking water

Water with presence of thermotolerant coliforms

Presence of bathroom in peridomicile

Presence of septic tank at home

Destination of household waste (burned)

Presence of any animal

Grown food predominating in last meal

Case of diarrhea in the previous two months in the residence

Case of diarrhea in less than a month in the residence

$\begin{array}{cc}91(59.5) & 62(40.5) \\ 79(51.6) & 74(48.4) \\ & \\ 89(58.2) & 64(41.8) \\ 153(100.0) & - \\ 153(100.0) & - \\ 87(56.9) & 66(43.1) \\ 76(49.7) & 77(50.3) \\ 65(42.5) & 88(57.5) \\ 99(64.7) & 54(35.3) \\ 33(21.6) & 120(78.4) \\ 143(95.4) & 10(4.6) \\ 153(100.0) & - \\ 91(59.5) & 62(40.5) \\ 135(88.2) & 18(11.8) \\ & \\ 99(64.7) & 54(35.3)\end{array}$

$91(59.5)$

$62(40.5)$

$4(48.4)$

$4(41.8)$

$66(43.1)$

$77(50.3)$

$88(57.5)$

$120(78.4)$

10(4.6)

$62(40.5)$

$54(35.3)$

Only $64.7 \%(n=99)$ of the residents had a bathroom inside the house. The use of septic tank occurred in $21.6 \%$ of cases $(n=33)$, the remaining residents were using black sump $(\mathrm{n}=89$, $58.2 \%$ ) or open sewage discharge $(\mathrm{n}=31,20.3 \%$ ). As for the household waste disposal, $95.4 \%$ of Kalunga community $(n=146)$ accumulated it on the ground for burning later. The presence of domestic animals was found in all residences. The occurrence of diarrhea in the previous two months was reported by $88.2 \%$ of respondents $(n=135)$ and $64.7 \%$ in the last month $(n=99)$.

The prevalence of intestinal parasites was $16.8 \%$. Table 2 shows the distribution of the sample according to the presence of infestation. The municipality of Cavalcante had $13.3 \%$ of positive results for intestinal parasites, all Endolimax nana. Teresina de Goiás had 26.0\%, of which $42.9 \%$ of Entamoeba coli, $28.6 \%$ of Iodomoeba butshilii, $14.3 \%$ of E. nana, $7.1 \%$ of Entamoeba bystolitica and $7.1 \%$ of hookworms. Monte Alegre lot had $10.2 \%$ of positive results, of which $40.0 \%$ of E. coli, $20.0 \%$ of E. nana, $20.0 \%$ of E. bystolitica , $10.0 \%$ of I. butshilii and $10.0 \%$ of hookworms. The variables gender, age and education showed a similar distribution, not constituting determinant for infestation. Among infested people, $14.1 \%$ reported diarrhea in the last month; $10.2 \%$ used water with the presence of thermotolerant coliforms; and $91.7 \%$ did not wash their hands regularly after physiological eliminations. There was a statistically significant association with the last two variables, with $\mathrm{p}=0.031$ and $\mathrm{p}=0.001$, respectively.

Table 2.Distribution of infestation according to municipality, gender, age group and educational level

\begin{tabular}{lccc}
\hline Variables & Infestation & \\
& Yes & & No \\
\hline
\end{tabular}




\begin{tabular}{|c|c|c|}
\hline & n $(\%)$ & n $(\%)$ \\
\hline \multicolumn{3}{|l|}{ Municipality } \\
\hline Cavalcante & $2(13.3)$ & $13(86.7)$ \\
\hline Teresina de Goiás & $13(26.0)$ & $37(74.0)$ \\
\hline Monte Alegre de Goiás & $9(10.2)$ & $79(89.8)$ \\
\hline \multicolumn{3}{|l|}{ Gender } \\
\hline Male & $10(15.6)$ & $54(84.4)$ \\
\hline Female & $14(15.7)$ & $75(84.3)$ \\
\hline \multicolumn{3}{|l|}{ Age group (years) } \\
\hline$<18$ & $13(16.3)$ & $67(83.8)$ \\
\hline $18-50$ & $7(13.7)$ & $44(86.3)$ \\
\hline$>51$ & $4(18.2)$ & $18(81.8)$ \\
\hline \multicolumn{3}{|l|}{ Educational level } \\
\hline Literate & 13(17.3) & $62(82.9)$ \\
\hline Iliterate & $11(14.1)$ & $67(85.9)$ \\
\hline \multicolumn{3}{|c|}{$\begin{array}{l}\text { Diarrheal episode in the last } \\
\text { month }\end{array}$} \\
\hline Yes & $14(14.1)$ & $85(85.9)$ \\
\hline No & $10(18.5)$ & $44(81.5)$ \\
\hline \multicolumn{3}{|c|}{$\begin{array}{l}\text { Thermotolerantes coliforms in } \\
\text { water }\end{array}$} \\
\hline Yes & $9(10.2)$ & $79(89.8)$ \\
\hline No & $15(23.1)$ & $50(76.9)$ \\
\hline \multicolumn{3}{|c|}{$\begin{array}{l}\text { Do you always wash your } \\
\text { hands after using the toilet? }\end{array}$} \\
\hline Yes & $2(3.5)$ & $55(96.5)$ \\
\hline No & $22(22.9)$ & $74(77.1)$ \\
\hline
\end{tabular}

Table 3 shows the results of the percentage distribution of the sample by occurrence of diarrhea in the last month.

Table 3. Distribution of cases of diarrhea in the last month according to sanitary conditions of households and infestations by parasites

\begin{tabular}{lcc}
\hline Variables & \multicolumn{2}{c}{ Diarrheal episode in the last month } \\
Yes & $\mathbf{n}(\mathbf{\%})$ & $\mathbf{n}(\mathbf{\%})$ \\
\hline Infestation & $14(58.3)$ & $10(41.5)$ \\
$\quad$ Yes & $85(65.9)$ & $44(34.1)$ \\
$\quad$ No & & \\
Education level & $52(66.7)$ & $26(33.3)$ \\
$\quad$ Iliterate & $47(62.7)$ & $28(37.3)$ \\
$\quad$ Literate & $1(33.3)$ & $2(66.7)$ \\
Type of parasite & $6(60.0)$ & $4(40.0)$ \\
Cysts of Endolimax nana & $3(100.0)$ & - \\
Cysts of Iodomoeba butshilii & $3(50.0)$ & $3(50.0)$ \\
Cysts of Entamoeba coli & $2(100.0)$ & - \\
Cysts of Entamoeba bistolytica & & \\
Eggs of ancilostomideo & & \\
\hline
\end{tabular}




\begin{tabular}{|c|c|c|}
\hline $\begin{array}{l}\text { Entamoeba bystolitica }+ \text { eggs of } \\
\text { hookworms }\end{array}$ & - & $1(100.0)$ \\
\hline \multicolumn{3}{|l|}{ Tap water inside the house } \\
\hline Yes & $64(73.6)$ & $23(26.4)$ \\
\hline No & $35(53.0)$ & $31(47.0)$ \\
\hline \multicolumn{3}{|l|}{$\begin{array}{l}\text { Presence of bathroom inside } \\
\text { the house }\end{array}$} \\
\hline Yes & $66(66.7)$ & $33(33.3)$ \\
\hline No & $33(61.1)$ & 21(38.9) \\
\hline \\
\hline & \multicolumn{2}{|c|}{ Thermotolerants Coliforms } \\
\hline Yes & $63(71.6)$ & $25(28.4)$ \\
\hline No & $36(55.4)$ & $29(44.6)$ \\
\hline \multicolumn{3}{|l|}{ Treatment of drinking water } \\
\hline Yes & $36(46.8)$ & $41(53.2)$ \\
\hline No & $63(82.9)$ & $13(17.1)$ \\
\hline \multicolumn{3}{|l|}{$\begin{array}{l}\text { Do you always wash your } \\
\text { hands after using the toilet? }\end{array}$} \\
\hline Yes & $41(71.9)$ & $16(28.1)$ \\
\hline No & $58(60.4)$ & $38(39.6)$ \\
\hline
\end{tabular}

It was evident that among the infected individuals $(\mathrm{n}=24), 58.3 \%$ reported diarrhea episodes in the previous month. However, only $14.1 \%$ of the residents without infestation reported such reference.

The education variable inferred that there were no significant differences between literate and illiterate regarding the occurrence of diarrheal episode in the previous month. In the association between the occurrence of diarrhea in the last month and parasite species responsible for the infestation, the values were: $33.3 \%(\mathrm{n}=1)$ with E. nana, $60 \%(\mathrm{n}=6)$ with I. butshilii, 100.0 $\%(\mathrm{n}=3)$ with E. coli, and 50.0\% (n = 3) with E. histolytica; $100.0 \%(\mathrm{n}=2)$ of those infested by E. hystolitica and hookworm also reported diarrhea in the previous month.

Piped water showed a statistical significance in association with diarrheal episode in the last month $(\mathrm{p}=0.008)$. Both in homes with indoor bathroom and in others, there was a high percentage of affirmative responses for the occurrence of diarrheal episodes: $66.7 \%(\mathrm{n}=66)$ and $61.1 \%(n=33)$, respectively. There was a statistically significant association $(p=0.038)$ between the variables diarrheal episodes and presence of thermotolerant coliforms in the water, while $71.6 \%$ ( $n=63$ ) of households supplied by water with thermotolerant coliforms reported diarrheal episodes in the previous month. Treatment with drinking water expressed strong association $(\mathrm{p} \leq 0.001)$ with the occurrence of diarrhea in the last month. The group that did not treat the drinking water had $82.9 \%(n=63)$ of cases of diarrheal episode in the previous 30 days. Washing hands after using toilets or equivalent was not statistically significant regarding the diarrheal episode variable; however, the non-occurrence of diarrheal episodes was lower in 
percentage among Kalunga residents who reported regularly washing the hands ( $\mathrm{n}=16,28.1 \%$ ) compared with those who reported no such regularity $(n=38,39.6 \%)$.

\section{Discussion}

The limit of the results of this study refers to the cross-sectional design, in which the possible associations between variables are known only during analysis of data, thus not allowing a temporal knowledge of when a certain fact would have occurred, or even how a certain evolution would have happened.

It is relevant to know the parasitological profile of such a singular community, because it can contribute to the planning and programming of local and regional actions that address the real needs of the Kalunga community, taking into account cultural considerations, the tradition, the customs and values. The results of this study may have practical applicability in the field of public health, which is a vast practice area of nurses.

The exposure of the Kalunga community to predictors of occurrence of intestinal parasite infestations was observed. This is because the risk factors for intestinal parasites are the poor sanitary, educational, social and economic conditions; lack of water treatment for human consumption; the high rate of agglomeration of people; inappropriate soil use, as well as its contamination and of the food. ${ }^{(7)}$

These results suggest that intestinal parasites diseases can arise as a disorder capable of illustrating the interface between health and social conditions, demonstrating by means of the high proportion of infestation, the risk of exposure of residents and diarrhea cases ${ }^{(8)}$, and taking into account that water comes from rivers, through hoses, wells or active uptake in gallons. In most homes, it does not receive treatment before consumption. This is heightened in serious problem, since untreated water can be a source of transmission of diseases, including intestinal diseases. $^{(9)}$

Most of this group had no permanent formal employment, surviving through activities at the margins of existing labor standards in the country. Many families were below the poverty line or even indigence. ${ }^{(10)}$ Educational level was low because among the literate, $45.1 \%$ had only incomplete primary education; illiterates accounted for 51.0\%. This reality revealed discrepancy relative to other regions because according to the Brazilian Institute of Geography and Statistics (IBGE - Instituto Brasileiro de Geografia e Estatística), the illiteracy rate is twice the national average of $8.6 \%$ among residents of rural areas. ${ }^{(11)}$

In the studied villages, there was no demarcation of streets and there was certain isolation between houses. These followed the traditional style used by black ancestors who built their 
houses with local materials. ${ }^{(12)}$ Such physical, simple and rustic structure (adobe walls, burnt cement floor or earthen floor) associated with the sanitary standards of the population reflects the precarious socioeconomic conditions. ${ }^{(13)}$

The sanitary infrastructure is one of the main health demands of the community. Not all residents had a bathroom; 64.7\% reported having bathroom just around the homes; and 34.3\% used rivers or the soil for physiological eliminations. In houses with presence of excreta disposal system, $(78.7 \%)$ open sewage discharge and black sumps were predominant. The community had no regular waste collection and in $95.4 \%$ of cases this accumulation occurred on the ground to burn later. In every home, there were domestic animals, both within domestic space as around the houses. This situation of absence of toilet in most homes, accumulation of solid waste and disposal of human waste and household animals, favors not only the proliferation of vectors and microorganisms that cause endemic diseases and parasites, but also contamination of surface water sources. $^{(13)}$

The presence of thermotolerant coliforms in waters that supplied $42.5 \%$ of homes reinforces the hypothesis that the effluent waste produced can reach the sources of drinking water when they percolate the soil. ${ }^{(9)}$

Intestinal parasites are an important indicator of the hygiene and sanitation conditions of the entire population. ${ }^{(14)}$ This corroborates the findings in the Kalunga community described so far, supporting the statistical significance $(\mathrm{p}=0.031)$ found between the variables presence of thermotolerant coliforms and infestation by enteropathogens.

The parasites identified in the study have mechanisms of fecal-oral transmission, with prevalence of the non-pathogenic over the pathogenic. ${ }^{(13)}$ This indicates contamination with fecal waste, which is plausible of understanding when considering the poor sanitary conditions of the Kalunga community. ${ }^{(6)}$ The finding reinforces the need of investment in preventive actions to promote health, especially in education and health, in infrastructure and basic sanitation. ${ }^{(15-17)}$

The close relationship between hygiene habits and enteroparasite infestation ${ }^{(18)}$ supports the statistical significance $(\mathrm{p}=0.001)$ found between handwashing and infestation variables. Our hands serve as a vehicle of fecal-oral contamination, therefore, the lack or failure of principles of hygiene such as handwashing is a predisposing factor to infestation by intestinal parasites. ${ }^{(5,19)}$

Diarrhea has approximately $88 \%$ of its occurrence attributed to water supply, inadequate sewage and hygiene. ${ }^{(20)}$ This fact justifies the high rates of diarrheal episodes in previous months to conducting the study: $64.7 \%$ in first month and $88.2 \%$ in the second. Although these conditions are not directly responsible for the occurrence of diarrhea, they favor the proximity of 
its determinants. ${ }^{(1)}$ Furthermore, the diarrheal event is related to the action of the parasite, with clinical manifestations proportional to the harbored parasite load. ${ }^{(5)}$

The presence of infestation showed a similar pattern across the variables of municipality, gender, age and education. The proximity of the data can be related to the fact that Kalunga habitants live in towns / villages with no exact boundaries and similar living conditions. ${ }^{(21)}$ The statistical significance $(\mathrm{p}=0.048)$ of the municipality variable confirmed the proposed.

The occurrence of diarrhea had statistical significance in the association with presence of thermotolerant coliforms and piped water. The unavailability of piped water is a determinant factor of diarrheal disorder because easy access to water contributes to personal, domestic and food hygiene, without which it is impossible to break the cycle of intestinal parasites transmission. ${ }^{(22)}$ In addition, water quality is a potentiating factor of interruption of the chain. ${ }^{(18)}$

As previously described by other authors, the study also showed that in the Kalunga community sanitation conditions were deficient, public services of water treatment non-existing, and living conditions were inadequate in terms of infrastructure and Quality of Life. ${ }^{(6,2324)}$ This scenario is aggravated by the disposal of human and solid waste in peridomestic areas close to rivers; by the consumption of untreated water; and the contamination of water by thermotolerant coliforms. All these are associated with the prevalence of insufficient hygiene habits, high percentage of parasites and poor sanitation. ${ }^{(25)}$

Such environmental fragility negatively impacts on the social determinants of health and keeps the Kalunga community prone to intestinal parasites. ${ }^{(9)}$

\section{Conclusion}

The Kalunga community showed infestation by different parasites associated with diarrheal episodes. Cases of diarrhea were associated with precarious hygiene conditions, especially the lack of drinking water treatment.

\section{Acknowledgement}

Thanks to the support provided by the Coordenação de Aperfeiçoamento de Pessoal de Nível Superior (Capes) under process BEX 3914 / 13-5 and the Programa Institucional de Bolsas de Doutorado Sanduíche no Exterior.

\section{Contribution}

Rangel DLO contributed to project design, execution of the research, drafting the article and relevant critical revision of the intellectual content. Oliveira C; Kyaw CM and Caldeira Júnior 
AM contributed to the execution of the research. Monteiro PS contributed to the final approval of the version to be published.

\section{References}

1. Sant'anna CF, Cezar-Vaz MR, Cardoso LS, Erdmann AL, Soares JFS. [Social determinants of health: community features and nurse work in family health care]. Rev Gaucha de Enferm. 2010;31(1):92-9. Portuguese.

2. Frei F, Juncansen C, Ribeiro-Paes JTR. [Epidemiological survey of intestinal parasite infections: analytical bias due to prophylactic treatment]. Cadernos de Saúde Pública. 2008;24(12):219-25. Portuguese.

3. Menezes RA O, Gomes MSM, Brabosa FHF, Brito GCMB, Proietti Junior AA, Couto AARDA. [Intestinal Parasites in residente population in humid área in Macapá, Amapá, Brazil]. Revista de Biologia e Ciências da Terra. 2013;13(2):10-18. Portuguese.

4. Magalhães NA, Koyanagi R. [Photo essay: Kalunga's territory in Vão das Almas community in the satate of Goiás]. Revista RDP. 2013;1(1):198-201. Portuguese.

5. Andrade EC, Leite IG, Rodrigues IO, Cesca MG. [Intestinal parasites: a review of its social aspects, epidemiological, clinical and therapeutic]. Revista de APS. 2010;13(2):231-40. Portuguese.

6. Fioravant MCS, Sereno JRB, Neiva ACGR, Abud LJ, Lobo JR, Francescantônio DD, et al. Reintroduction of cattle Curraleiro maroon community in the Kaluga Cavalcante, Goiás, Brazil. Partial results]. In: IX Simpósio Nacional do Cerrado, II Simpósio Internacional de Savanas Tropicais; 2008 Oct 12-17; Brasília, DF: PariaMundi; 2008.

7. Borges WF, Marciano FM, Oliveira HB. [Intestinal parasites: high prevalence of Giardia lamblia. in patients treated by the Public Health Service in Southeast Region of Goiás, Brazil]. Revista de Parasitologia Tropical. 2011;40(2):149-57. Portuguese.

8. Nyarango RM, Aloo PA, Kabirun EW, Nyanchongi BO. [The risk of pathogenic intestinal parasite infections in Kisii Municipality, Kenya]. BMC Public Health. 2008;237(8):1-6.

9. Cordeiro MR, Rodrigues AM, Souza PRN, Ferreira MIP. [Assessment of the contamination with domestic wastewater in supply wells over sandbank area]. Boletim do Observatório Ambiental Alberto Ribeiro Lamego. 2011;5(1):89-102. Portuguese.

10. Tibúrcio BA, Valente ALEF. [Is the fair trade an alternative for impoverished segments of the population? Case study in Kaluga Territory (GO)]. Rev Econ Sociol Rural. 2007;45(2):497-519. Portuguese. 
11. Instituto Brasileiro de Geografia e Estatística (IBGE). Coordenação de População e Indicadores Sociais. Síntese de indicadores sociais: uma análise das condições de vida da população brasileira: 2012. Rio de Janeiro: IBGE; 2012.

12. Araujo RE, Foschiera AA. [Contradictions between the reality socioeconomic community quilombola Mimoso do Kalunga warranty and legal rights education and territory]. Revista Pegada. 2012;13(2):203-27. Portuguese.

13. Amorim MM, Tomazini L, Silva RAA, Gestinari RS, Figueiredo TB. [Evaluation of housing conditions and health community Quilombola Boqueirão, Bahia, Brazil]. Biosci Journal. 2013;29(4):1049-57. Portuguese.

14. Cantuária FD, Cocco J, Bento RRL, Ribeiro F. [Evaluation of intestinal parasitosis in schoolchildren in the municipality of Coração de Jesus, State of Minas Gerais, Brazil]. RBAC. 2011;43(4):277-83. Portuguese.

15. Ngui R, Ishak S, Chuen CS, Mahmud R, Lim YAL. [Prevalence and Risk Factors of Intestinal Parasitism in Rural and Remote West Malaysia]. PLoS Negl Trop Dis. 2011;5(3):17.

16. Gonçalves ALR, Belizário TL, Pimentel JB, Penatti MPA, Pedroso RS. [Prevalence of intestinal parasites in preschool children in the region of Uberlândia, State of Minas Gerais, Brazil]. Rev. Soc. Bras. Med. Trop. 2011;44(2):191-3.

17. Oramas JL, Rodrígues AP, Villavilla CMF, Pérez JS. [Parasitismo Intestinal em uma cohorte de escolares em 2 municipios de Ciudad de La Habana]. Revista Cubana de Medicina Tropical. 2008;60(3):114-28. Spanish.

18. Santos AS, Merlini LS. [Prevalence of enteroparasitosis in the population of Maria Helena, Paraná State]. Ciênc Saúde Coletiva. 2010;15(3):899-905. Portuguese.

19. Londoño AL, Mejía S, Gómez-Marín JE. [Prevalence and risk factors associated with intestinal parasitismo in preschool children from the urban area of Calarcá, Colombia]. Rev. Salud Pública. 2009;11(1):72-81. Spanish.

20. Reymão AE, Saber BA. [Access to clean water and insufficient income Two dimensions of the problem of poverty in the Northeast Brazil from the perspective of the Millennium Development Goals]. Revista Iberoamericana de Economía Ecológica. 2009;12(1):1-15. Portuguese.

21. Souza CLF. [The community Kalunga]. Ateliê Geográfico. 2010;4(1):196-210. Portuguese.

22. Freitas DA, Cabaleto A, Hernande C, Antunes S. [Health and quilombolas communities]. Revista CEFAC. 2011;13(5):937-43. Portuguese. 
23. Neiva ACGR, Sereno JRB, Fiorivanti MCS. [Geographical indication in conservation and value aggregation to curraleiro cattle of the Kalunga community]. Archivos de Zootecnia. 2011;231(60):357-60. Portuguese.

24. De Lima LNM. [The constitution of an identity territory for a warranty of land rights: The Historical and Cultural Site Kalunga]. Soc. \& Nat. 2013;25(3):502-12. Portuguese.

25. Dagei H, Kurt Ö, Demirel M, Östan I, Azizi NR, Mandiracioglu A et al. [The prevalence of intestinal parasites in the province of Izmir, Turkey]. Parasitol Res. 2008;103(1):839-45. 
ANEXO E - Comprovante de submissão de artigo "Perfis socioeconômico e sanitário e significado de saúde para moradores da comunidade quilombola Kalunga" ao Corpo Editorial da Revista Saúde em Debate.

ÓRGÃO OFICIAL DO CEBES - Centro Brasileiro de Estudos de Saúde - ISSN 0103-1104

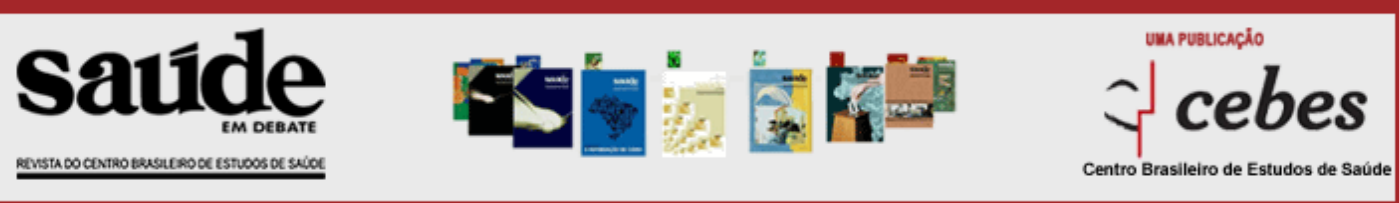

Seu trabalho Perfis socioeconômico e sanitário e significado de saúde para moradores da comunidade quilombola Kalunga foi recebido com sucesso.

Ele será encaminhado à Comissão Científica para análise e seleção.

Você poderá acompanhar o status da avaliação de seu trabalho através de sua área restrita, informando o login e a senha de acesso, que você cadastrou no momento de seu registro.

Atenciosamente,

Revista Saúde em Debate 
ANEXO F - Comprovante de submissão de artigo "Mercúrio em peixes e em cabelo de populações residentes em região de garimpo" ao Corpo Editorial da Revista da Escola de Enfermagem da Universidade de São Paulo - REEUSP.

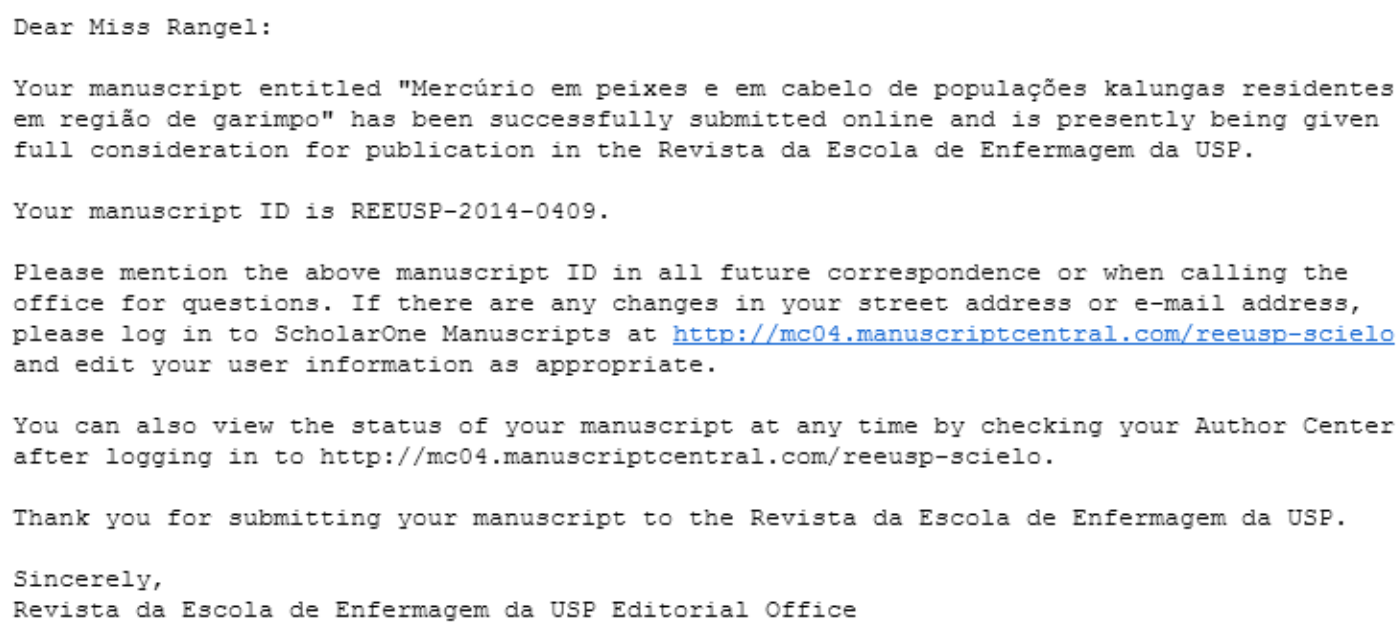

